UNIVERSIDADE DE SÃO PAULO

FACULDADE DE ECONOMIA, ADMINISTRAÇÃO E CONTABILIDADE DEPARTAMENTO DE ADMINISTRAÇÃO PROGRAMA DE PÓS-GRADUAÇÃo EM ADMINISTRAÇÃo

EMPREENDEDORISMO SOCIAL E PROMOÇÃO DO DESENVOLVIMENTO LOCAL

Monica Bose

Orientadora: Prof ${ }^{\text {a }}$ Dra. Rosa Maria Fischer 

Prof. Dr. João Grandino Rodas Reitor da Universidade de São Paulo

Prof. Dr. Reinaldo Guerreiro

Diretor da Faculdade de Economia, Administração e Contabilidade

Prof. Dr. Adalberto Américo Fischmann

Chefe do Departamento de Administração

Prof. Dr. Lindolfo Galvão de Albuquerque Coordenador do Programa de Pós-Graduação em Administração 
MONICA BOSE

\section{EMPREENDEDORISMO SOCIAL E PROMOÇÃO DO DESENVOLVIMENTO}

\section{LOCAL}

Tese apresentada Departamento de Administração da Faculdade de Economia, Administração e Contabilidade da Universidade de São Paulo como requisito para obtenção do título de Doutor em Administração.

Orientadora: Prof ${ }^{\text {a }}$ Dra. Rosa Maria Fischer

\section{Versão Corrigida}

(versão original disponível na Faculdade de Economia, Administração e Contabilidade)

\section{SÃO PAULO}




\section{FICHA CATALOGRÁFICA}

Elaborada pela Seção de Processamento Técnico do SBD/FEA/USP

\section{Bose, Monica}

Empreendedorismo social e promoção do desenvolvimento local / Monica Bose. - São Paulo, 2012. $182 \mathrm{p}$.

Tese (Doutorado) - Universidade de São Paulo, 2012. Orientador: Rosa Maria Fischer.

1. Empreendedorismo social 2. Desenvolvimento social 3. Terceiro setor I. Universidade de São Paulo. Faculdade de Economia, Administração e Contabilidade. II. Título.

$$
\text { CDD }-361.2
$$



A todos aqueles que sonham, acreditam, realizam e transformam este mundo num lugar mais justo e humano. 

Agradeço a todos que contribuíram para a realização deste estudo.

À Profa. Dra. Rosa Maria Fischer, orientadora e amiga, a quem atribuo muitas das ideias e sonhos que brotaram neste percurso.

Aos meus colegas do CEATS, que tanto colaboraram com discussões e muito entusiasmo, sobretudo Fu Kei Lin, Luana Schoenmaker e Alda Araujo. À Elídia Novaes por ter, adicionalmente, colaborado com a revisão deste trabalho.

A tantos colegas da FEA/USP que me acompanharam nesta trajetória, sobretudo Luciana Rocha de Mendonça e Edileusa Godói de Souza, pelas valiosas ideias, importantes contribuições e constante apoio.

À Cristina Úbeda Portabella pela competência e dedicação que aportou para enriquecer as pesquisas temáticas realizadas.

À Profa. Graziella Maria Comini e ao Prof. Mario Monzoni pelas críticas e sugestões aportadas no exame de qualificação, ampliando em muito o horizonte do estudo realizado.

Aos empreendedores sociais e a todas as pessoas ligadas às iniciativas estudadas, os quais aceitaram participar deste estudo e dedicaram seu precioso tempo à realização da pesquisa.

À Maricy Tango Bechara, amiga e conselheira de todas as horas, pela força e entusiasmo com que estimulou, apoiou e acompanhou mais esta jornada.

Ao meu companheiro de todos os momentos, Fabio Alves Barbará, pelas sugestões, revisões, discussões e, sobretudo, paciência e compreensão. E ao nosso novo companheiro de vida, Camilo Bose Barbará, por ter irradiado luz e alegria no meio deste percurso.

Ao Conselho Nacional de Desenvolvimento Científico e Tecnológico - CNPq, pela concessão da bolsa de estudos que viabilizou financeiramente a realização do estudo. 

"Você tem sede de que? Você tem fome de que?"

Arnaldo Antunes e Titãs 



\section{RESUMO}

O fenômeno do empreendedorismo social tem adquirido visibilidade e relevância no âmbito da produção acadêmica e, principalmente, das práticas organizacionais contemporâneas, por se constituir em mais uma alternativa de combate à pobreza e à exclusão social, e de promoção do desenvolvimento sustentável. Esta tese buscou identificar, em três casos situados na Região Metropolitana de São Paulo, se e como tais empreendimentos sociais têm provocado mudanças significativas no desenvolvimento social dos territórios nos quais atuam. Apoiando-se na concepção e nos vetores de desigualdade propostos por Amartya Sen (2000) para o desenvolvimento social, a pesquisa empírica procurou identificar os resultados obtidos por empreendimentos sociais em três iniciativas na Região Metropolitana de São Paulo. O estudo empregou uma abordagem metodológica qualitativa em um enfoque contextualista (PETTIGREW, 1989; FISCHER, 2002), o qual busca caracterizar o âmbito no qual se inserem alguns dos projetos realizados pelos empreendimentos analisados. Tais iniciativas foram estudadas como campos nos quais distintos agentes interagem e exercem influência, mobilizando os diferentes tipos de capitais que detêm, conforme proposta de Bourdieu (2007). Os dados coletados foram submetidos a análise conforme proposta metodológica de Roche (2002), partindo da identificação de mudanças percebidas pela população-alvo dos projetos. Empregou-se o estudo de caso múltiplo como método de pesquisa, conforme tipologia proposta por Yin (2010). Os dados foram coletados em documentos, observações e entrevistas, e foram categorizados por meio da técnica de análise de conteúdo, conforme proposta de Bardin (1977). Os resultados obtidos na pesquisa apontaram a existência de indícios de melhoria na qualidade de vida pessoal e familiar dos atores que participaram das iniciativas realizadas pelos empreendimentos sociais. As mudanças que atingem a localidade ou o território como um todo, configurando um incremento dos padrões de desenvolvimento, não são observadas em todos os casos e geralmente se concentram em uma ou outra dimensão do desenvolvimento social, como melhorias na esfera da riqueza material ou do bem-estar social. Os resultados alcançados pelos empreendimentos sociais pesquisados pouco contribuíram, até o momento da pesquisa, para fortalecer o capital social e político das comunidades envolvidas, bem como para alavancar o desenvolvimento econômico-social do território no qual estão inseridas. Devem ser considerados, entretanto, os impactos causados pelo pouco tempo de existência das iniciativas estudadas e pelo caráter inovador característico destas ações, sobre os resultados observados. 



\begin{abstract}
The phenomenon of social entrepreneurship has gained visibility and relevance in the scope of academic production, and especially of contemporary organizational practices, as it presents another alternative for fighting poverty and social exclusion, and promoting sustainable development. Through the observation of three cases in the Sao Paulo Metropolitan Area, this thesis has sought to identify if and how such social enterprises have caused significant changes in the social development of the territories in which they operate. Relying on the design and vectors of inequality proposed by Amartya Sen (2000) for social development, the empirical survey has sought to identify the results obtained by social enterprises in three initiatives in the metropolitan area of São Paulo. The study has adopted a qualitative methodology in a contextualist approach (PETTIGREW, 1989; FISCHER, 2002), which seeks to characterize the circumstance in which some of the projects undertaken by the enterprises analyzed are inserted. Such initiatives were studied as fields in which manifold agents interact and influence by mobilizing the different types of capital each of them hold, as proposed by Bourdieu (2007). The collected data were analyzed as Roche's methodological proposition (2002), based on the identification of changes perceived by the target population of the projects. The multiple-case study was used as a research method, as typology proposed by Yin (2010). Data were collected from documents, interviews and observations, and were categorized according to the technique of content analysis, as proposed by Bardin (1977). The results of the research have indicated signs of improvement in the quality of personal and family life of the actors who participated in the initiatives undertaken by the social enterprises. Changes that affect the location or territory as a whole, setting an increment in the development patterns, are not seen in all cases and are usually concentrated in one or the other dimension of social development, such as improvements in the sphere of material riches or social wellbeing. The results achieved by the social enterprises surveyed have contributed little, until the time of the survey, in strengthening social and political capital in the communities involved, as well as in leveraging the economic and social development of the territory in which they operate. However, one must also consider the impacts caused by the short lifetime of the initiatives studied and by the innovative character, typical of such actions, on the results attained.
\end{abstract}





\section{SUMÁRIO}

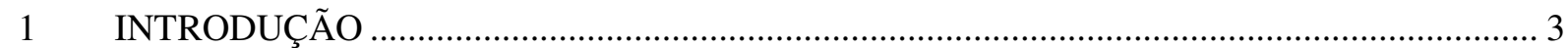

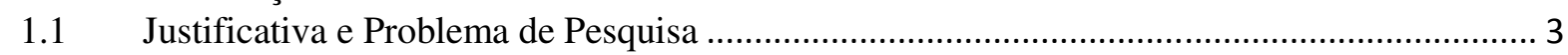

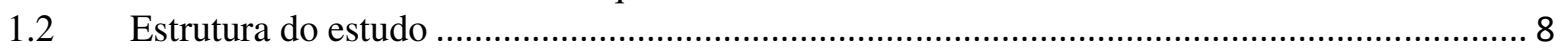

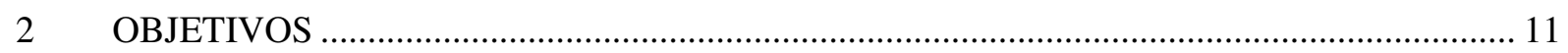

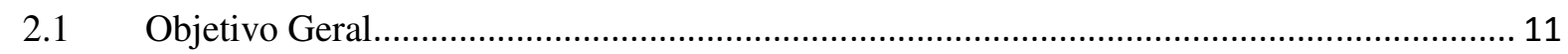

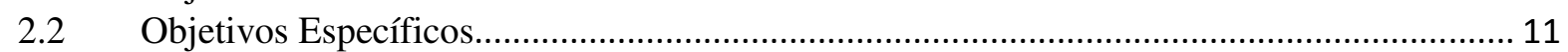

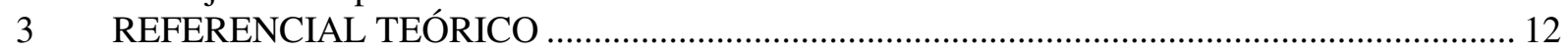

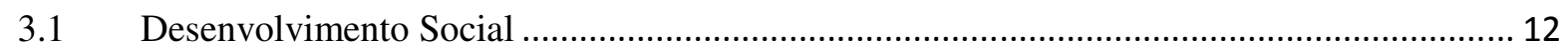

3.1.1 O Desenvolvimento Social no contexto do Desenvolvimento Sustentável ....................... 12

3.1.2 Desenvolvimento Social e Desenvolvimento Local ........................................................ 20

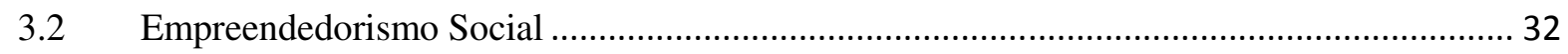

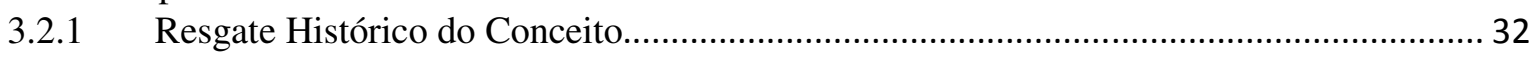

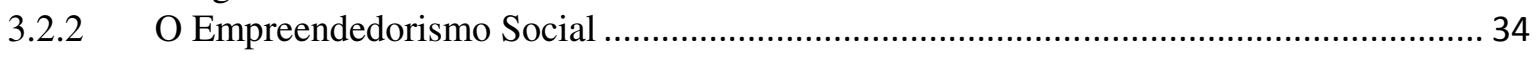

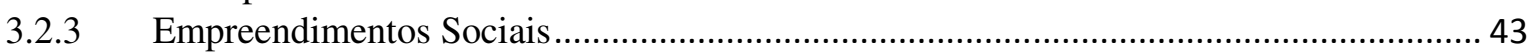

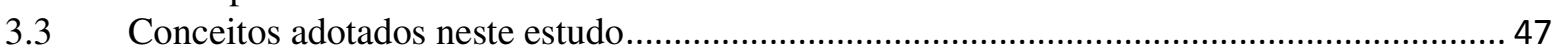

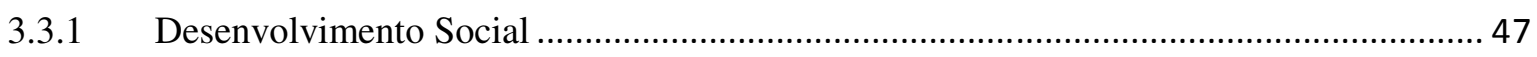

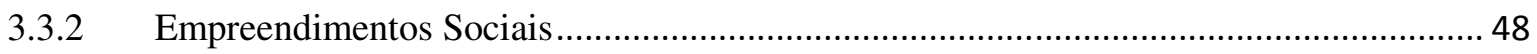

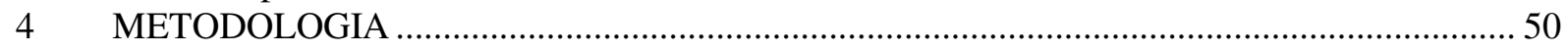

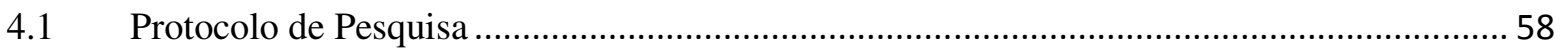

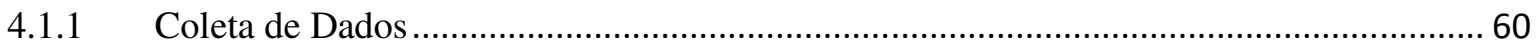

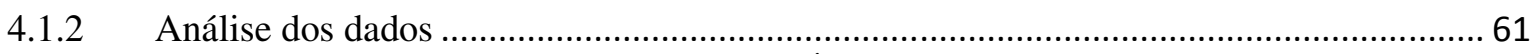

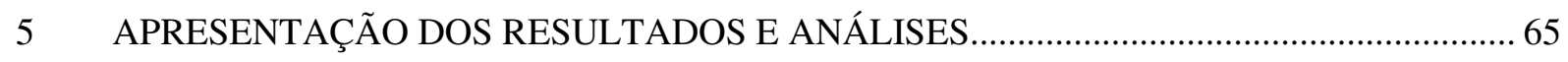

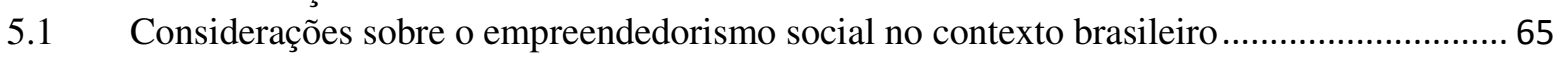

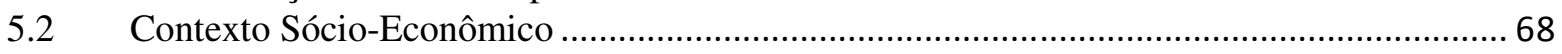

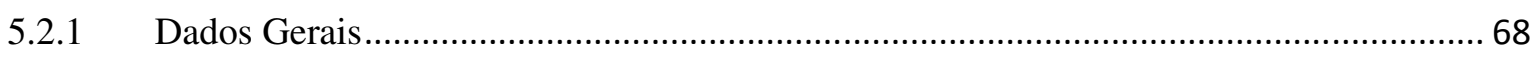

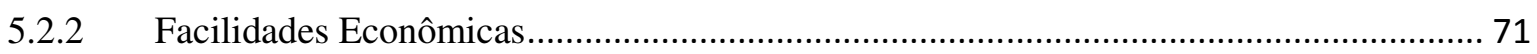

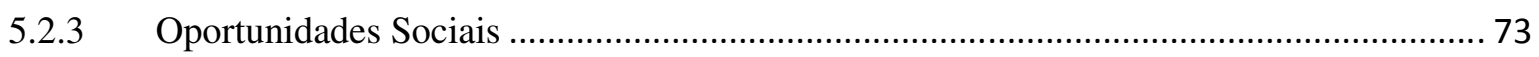

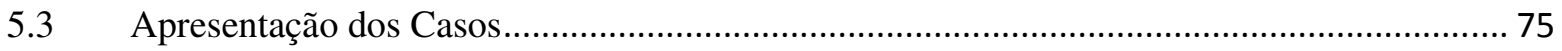

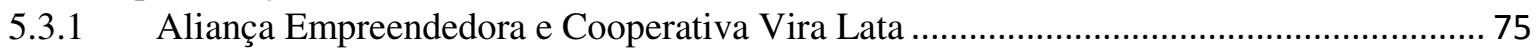

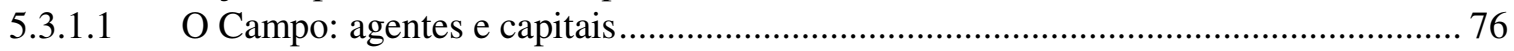

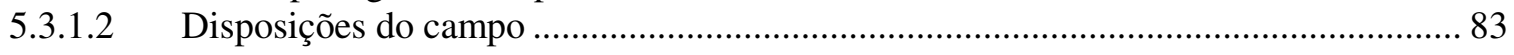

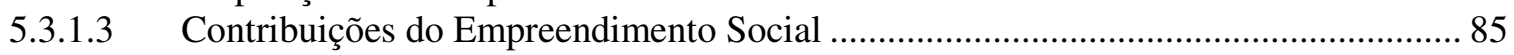

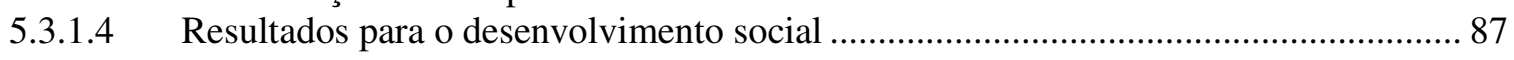

5.3.2 Fundo Zona Leste Sustentável .................................................................................. 91

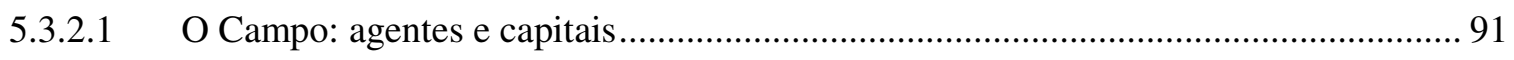

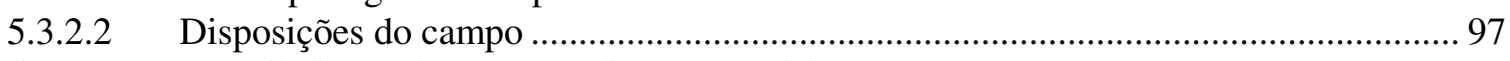

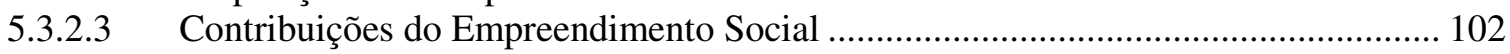

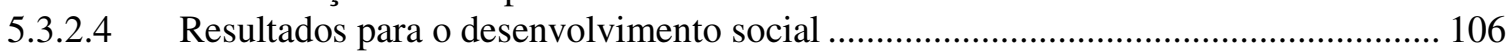

5.3.3 Interação e Comunidade dos Portais............................................................................... 111

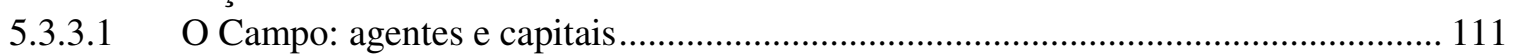

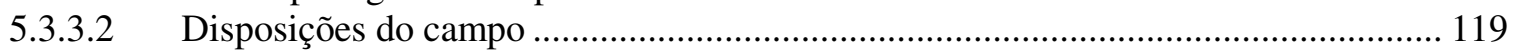

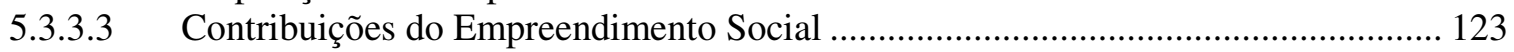

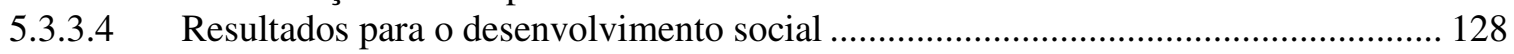

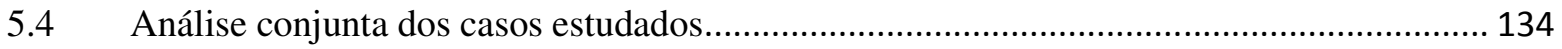

5.4.1 Características de contexto: campo, agentes e capitais................................................. 134

5.4.2 Empreendimentos sociais orientados para o desenvolvimento social ............................ 139

5.4.3 Fatores que influenciam a promoção do desenvolvimento social................................... 145

5.4.4 Resultados para o desenvolvimento social ............................................................... 151 


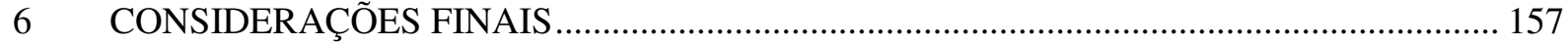

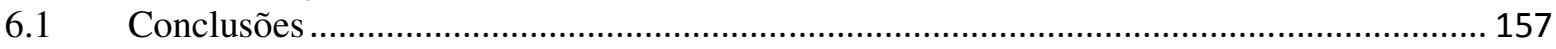

6.2 Limitações do estudo e recomendações para pesquisas futuras:........................................... 163

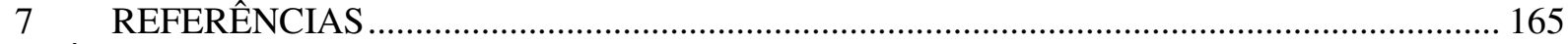

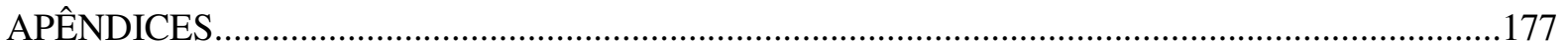




\section{INTRODUÇÃO}

\subsection{Justificativa e Problema de Pesquisa}

O desenvolvimento social foi um dos temas mais debatidos e relevantes do século XX. Ao longo daquele século, o crescimento econômico, obtido pela consolidação do capitalismo como sistema político-econômico dominante, não foi suficiente para gerar benefícios homogêneos em quantidade e qualidade para a população mundial, o que deu origem a inúmeras teorias sobre formas e meios para reduzir a pobreza e a exclusão socioeconômica. Ao final daquele século, essa discussão se consolidou em torno da promoção do Desenvolvimento Sustentável, o qual ressalta a interdependência entre as variáveis que determinam o crescimento econômico, o desenvolvimento social e a preservação ambiental (VEIGA, 2005a). Com isso, o debate não apenas adquiriu nova roupagem, como foi elevado a um patamar mais elevado nas agendas globais e nacionais, tornando-se prioridade entre os programas de desenvolvimento fomentados pelo poder público e pela iniciativa privada.

$\mathrm{Na}$ medida em que o debate e o pensamento sobre o desenvolvimento social eram enriquecidos por contribuições das ciências econômicas, sociais e políticas, experiências práticas de soluções para problemas sociais foram concebidas, testadas e implantadas diretamente por atores da sociedade civil, dando corpo ao fenômeno do Empreendedorismo Social. São iniciativas, programas e organizações criados para lidar com necessidades sociais complexas, através de ações que têm como objetivo principal a geração de valor social para um dado grupo de pessoas, uma dada comunidade ou um dado território. (ASHOKA, 2011; NICHOLLS, 2006; DEES, 2001; JOHNSON, 2000) Esses empreendimentos têm experimentado crescente visibilidade desde a última década do século XX (FISCHER, 2011). Atualmente podem ser facilmente identificados em todos os continentes, operando nas mais diversas realidades e buscando soluções para uma ampla gama de problemas sociais, que vão desde a erradicação da miséria até a defesa de direitos difusos, inclusive a sustentabilidade ambiental do planeta e a redução da desigualdade socioeconômica no mundo. São fomentados por recursos financeiros do setor público e da iniciativa privada, bem como de fundações e institutos privados com finalidades públicas, e buscam gerar receita financeira através de suas 
próprias atividades e da ação coletiva, movimentando parcela significativa de recursos nas economias locais e nacionais, além de promoverem a geração de emprego e renda.

O presente estudo se propõe a discutir as possíveis intersecções entre essas duas faces de uma mesma moeda: o Desenvolvimento Social e o Empreendedorismo Social. Parte-se do pressuposto de que as práticas e os conceitos que os dois temas encerram são extremamente próximos em suas finalidades, buscando responder a uma mesma questão: como promover transformações socioeconômicas que assegurem igualdade no acesso de todos os cidadãos a boas e sustentáveis condições de vida?

Essa inquietação emerge de reflexões construídas ao longo de uma década de pesquisas e assessorias realizadas junto a empreendimentos sociais, muitas das quais no âmbito do Centro de Empreendedorismo Social e Administração em Terceiro Setor (CEATS). Ao longo desta trajetória, tenho convivido com os sonhos e as esperanças de transformações fomentadas pelos empreendedores sociais, nutridos por meio de muita ousadia. Mas também tenho apurado indicadores que reiteram a persistência e, algumas vezes, o acirramento da pobreza, da miséria e da desigualdade. Compreender esse paradoxo motivou a realização desta tese, ainda que apenas algumas de suas facetas sejam reveladas nos limites do estudo realizado.

A persistência da enorme assimetria existente entre as potencialidades do planeta e a pobreza vivida por milhões de pessoas justifica, por si só, a realização de estudos que contemplem soluções, caminhos, alternativas e possibilidades para mudar esse cenário. Ainda na primeira década do século XXI, um bilhão de pessoas passa fome em todo o mundo, 1,2 bilhão não tem acesso a água potável e 2,6 bilhões não têm condições mínimas de saneamento. Como consequência, pobreza, desnutrição e condições críticas de saúde matam 18 milhões de pessoas por ano, metade delas com menos de cinco anos de idade (SEN; KLIKSBERG, 2007).

Embora muitos aspectos do desenvolvimento humano tenham experimentado progressos substanciais nos últimos 20 anos, houve, no mesmo período, o aumento de desigualdades entre países e dentro dos países. Para cada nação onde a desigualdade foi reduzida nos últimos 20 a 30 anos, mais de duas viram a desigualdade aumentar. O último Relatório de Desenvolvimento Humano, lançado em 2011, observa que a distribuição de renda medida 
pelo IDHAD $^{1}$ piorou na maioria das regiões do mundo, sendo a América Latina a região mais desigual em termos de renda. O Índice de Pobreza Multidimensional - IPM revela que, ao final de década de 2010, quase um terço da população total (1,7 bilhão de pessoas) vivia em pobreza "multidimensional"". Pelos tradicionais critérios de avaliação de pobreza do Banco Mundial, 1,3 bilhão de pessoas viviam em extrema pobreza, sobrevivendo com US\$1,25 ou menos por dia em 2010 (PNUD, 2010; PNUD, 2011).

Do ponto de vista do empreendedorismo social, Fischer (2011, p. 188) propõe a realização de estudos que prospectem as características e a atuação desses empreendimentos no sentido da erradicação da miséria, do alívio da pobreza e do estímulo ao desenvolvimento sustentável, perguntando "se e como estas iniciativas, fundamentadas neste conjunto de boas intenções, têm potencial para provocar, efetivamente, tais transformações sociais".

De acordo com Bill Drayton, fundador da Ashoka, organização pioneira no campo da inovação social e no apoio aos empreendedores sociais, 52\% dos 2700 empreendedores apoiados por aquela instituição mudaram alguma política nacional nos últimos cinco anos e $76 \%$ tem mudado o padrão nacional no seu campo de atuação (DRAYTON, 2010). Esses dados sugerem a importância da realização de pesquisas exploratórias neste campo.

São raros os estudos brasileiros que procuram identificar as relações entre as atividades executadas através de empreendimentos sociais e o desenvolvimento social. Alguns estudos tangenciam esta questão, ao estudarem o fenômeno do empreendedorismo como alternativa de autoemprego ou como elemento propulsor de novas relações econômicas locais; outros, ao buscar compreender aspectos da gestão de empreendimentos sociais.

Pesquisa realizada por Godói-de-Souza (2010) junto a 34 empreendimentos sociais demonstrou que essas iniciativas não têm conseguido ir além do plano de uma "reprodução simples" - aquele da sobrevivência dos grupos (FRANÇA FILHO; LAVILLE, 2004). Para

\footnotetext{
${ }^{1}$ O Índice de Desenvolvimento Humano Ajustado à Desigualdade (IDHAD) utiliza metodologia desenvolvida pelo economista britânico Anthony Barnes Atkinson, sendo considerada pelo PNUD "mais sensível a mudanças na extremidade inferior da escala do que o conhecido coeficiente de Gini" (PNUD, 2011).

${ }^{2} \mathrm{O}$ Índice de Pobreza Multidimensional (IPM) examina os fatores no âmbito familiar, como o acesso a água potável, combustível para cozinhar e serviços de saúde, assim como bens de consumo básicos e padrões de construção de casas. Juntos, esses indicadores fornecem um retrato mais completo da pobreza do que as medidas de renda sozinhas. (PNUD, 2011)
} 
esses autores, tais empreendimentos, agindo apenas nos circuitos populares da economia, marcados pela pobreza das condições de vida, funcionam em condições precárias, com baixo nível de estruturação interna e de articulação externa. Sendo assim, dificilmente conseguem ir além da geração de renda apenas para os seus membros diretamente envolvidos. Se determinados a contribuir para a promoção do desenvolvimento social, ainda que local, esses empreendimentos deveriam gerar ocupação e renda também para a própria comunidade, ativando um circuito de relações de troca, produção e consumo de bens e serviços que pudesse reforçar a cadeia socioprodutiva local.

O estudo realizado por Lima (2008) a respeito de empreendimentos sociais voltados para a geração de renda, localizados em favelas da cidade do Rio de Janeiro, também parte da possível contradição entre meios e fins do empreendedorismo social. De um lado, o empreendedorismo social como solução inovadora para a redução da pobreza teria como consequência a anulação de questões básicas de cidadania, do papel do Estado e das políticas universalizantes (VIANNA, 2007 apud LIMA, 2008). De outro, iniciativas de geração de renda para públicos marginalizados seriam uma alternativa ao desenvolvimento, uma forma de reação dos pobres aos limites da economia moderna (GIDDENS, 1996 apud LIMA, 2008). A pesquisa realizada com iniciativas apoiadas pelo SEBRAE-RJ conclui que o caráter de subsistência desses empreendimentos evidencia uma realidade social onde não existem direitos sociais e civis, reforçando a necessidade de ampliar o debate político sobre o acesso a políticas públicas desses grupos excluídos social e economicamente.

Mais otimista, Oliveira (2003, 2004a) identificou em seu estudo de caso que o empreendedorismo social gera uma nova forma de consciência e uma postura diferenciada no enfrentamento da pobreza, da desigualdade e da exclusão social. O pesquisador parte da constatação de que o grande desafio do século XXI é produzir ações eficientes e eficazes que promovam a emancipação social e o desenvolvimento humano dos sujeitos que são objeto destas ações. Sua inquietação reside na identificação de ações que, de fato, superem o círculo vicioso de regulação e controle da pobreza e, portanto, de manutenção do status quo. Ao estudar programas de fomento ao empreendedorismo social e casos de empreendimentos sociais, o autor constata que esse fenômeno tem relação positiva com o desenvolvimento social, sendo o "nascedouro de uma racionalidade crítica-criativa-propositiva" que, por natureza, promove ações concretas e coletivas no campo social. Sua pesquisa atesta que o empreendedorismo social gera transformação social, emancipação social e empoderamento 
dos cidadãos. Portanto, aumenta o estoque de capital social, contribuindo para o desenvolvimento sustentável e a justiça social.

Grisi (2008), em sua análise sobre programas de fomento ao empreendedorismo e ao empreendedorismo social, conclui que o desenvolvimento local é facilitado pela compreensão da cultura, das capacidades e dos talentos dos moradores da comunidade na qual o empreendimento se insere, associada à criação de condições financeiras, tecnológicas e humanas. Esse impacto é potencializado quando há apoio de programas governamentais específicos, sobretudo de educação para o empreendedorismo.

O trabalho de Albagli e Maciel (2002) também apresenta evidências de que a interação e as relações cooperativas entre os atores sociais e econômicos constituem um fator crucial, tanto do empreendedorismo como do desenvolvimento local de modo mais amplo.

Numa análise crítica da participação de agentes públicos, ao estudar a constituição do Arranjo Produtivo Moveleiro de Ubá-MG, Rovetta da Silva (2008) constatou que aquele ambiente de negócio foi fertilizado exclusivamente pelos empreendedores locais, num contexto onde a ação governamental limitou-se ao papel de financiadora destas iniciativas. $\mathrm{O}$ autor conclui que a reunião de empreendedores locais em espaços institucionalizados de cooperação e fomento da atividade produtiva foi condição determinante para o desenvolvimento daquele Arranjo Produtivo Local. ${ }^{3}$

O impacto do empreendedorismo social na transformação local, na "criação de novas comunidades", é centrado nas contribuições que essas iniciativas trazem para a qualidade de vida das populações beneficiadas, de acordo com estudo realizado por Farfus (2008, p.109) junto a 61 egressos do Programa SESI Empreendedorismo Social no Paraná. A pesquisadora aponta, em suas conclusões, que "a percepção do empreendedor em relação a sua contribuição com o desenvolvimento local, colaborando com o individual e coletivo, é ponto de partida para um novo estudo".

\footnotetext{
${ }^{3}$ Arranjos Produtivos Locais (APL) são aglomerações de empresas, localizadas em um mesmo território, que apresentam especialização produtiva e mantêm vínculos de articulação, interação, cooperação e aprendizagem entre si e com outros atores locais, tais como: governo, associações empresariais, instituições de crédito, ensino e pesquisa. (Ministério do Desenvolvimento, Indústria e Comércio Exterior, 2011)
} 
Visando aprofundar essas reflexões e trazer elementos que contribuam para a constituição de um quadro teórico sobre o tema, o problema de pesquisa que fundamenta este estudo é: $\mathrm{O}$ empreendedorismo social de fato contribui para a promoção do desenvolvimento social em âmbito local? Este problema insere o estudo em uma perspectiva que busca chegar a contribuições teóricas que complementam as teorias existentes sobre Empreendedorismo Social e Desenvolvimento Social, e suas intersecções.

\subsection{Estrutura do estudo}

Este trabalho está estruturado em seis capítulos. Após esta introdução, que apresenta o tema, a justificativa e o problema de investigação, serão apresentados os objetivos que nortearam o desenvolvimento da pesquisa, compondo o Capítulo 2.

O Capítulo 3 apresenta a fundamentação teórica adotada na pesquisa, a qual versa sobre desenvolvimento social e empreendedorismo social. O primeiro tema contempla duas discussões: uma que o insere no contexto das teorias sobre desenvolvimento sustentável, e uma segunda abordagem que focaliza o desenvolvimento social em sua perspectiva local. $\mathrm{O}$ empreendedorismo social é discutido sob a ótica das origens históricas do termo, seguindo-se uma análise dos conceitos que lhe são atribuídos e, por fim, são apresentadas as características distintivas dos empreendimentos sociais.

O arcabouço metodológico construído e empregado para a realização do estudo é apresentado no Capítulo 4. Ali, são descritos os fundamentos metodológicos e conceituais que guiaram a realização da pesquisa de campo, com foco na aplicação das noções de campo e de habitus desenvolvidas por Bourdieu, e na proposição de indicadores de resultados. Segue-se o detalhamento do protocolo de pesquisa utilizado para coleta e análise dos dados.

O Capítulo 5 apresenta os resultados obtidos com a realização da pesquisa e as análises que eles propiciaram. Inicialmente, é descrito um conjunto de considerações sobre o empreendedorismo social no contexto brasileiro, à luz de contribuições aportadas por especialistas entrevistados na fase inicial da pesquisa. A sessão seguinte apresenta os indicadores que caracterizam o contexto socioeconômico da Região Metropolitana de São Paulo, onde se inserem os três casos estudados. Estes são apresentados nas sessões seguintes, 
descritos e analisados sequencialmente. O capítulo é finalizado com uma análise conjunta dos três casos pesquisados à luz dos objetivos específicos do estudo.

O último capítulo apresenta as conclusões obtidas no estudo, considerações finais sobre sua realização e recomendações para pesquisas futuras. 


\section{OBJETIVOS}

\subsection{Objetivo Geral}

Compreender se e como os resultados obtidos por empreendimentos sociais constituídos no Brasil contribuem para o desenvolvimento social em âmbito local.

\subsection{Objetivos Específicos}

Identificar e analisar como os empreendimentos sociais atuam visando contribuir com a promoção do desenvolvimento social em âmbito local.

Analisar a existência de indícios de que os empreendimentos sociais contribuem para a promoção do desenvolvimento social em âmbito local.

Identificar e analisar os fatores alavancadores e restritores que influenciam a promoção do desenvolvimento almejado pelos empreendimentos sociais. 


\section{REFERENCIAL TEÓRICO}

Os temas empreendedorismo social e desenvolvimento social, bem como suas intersecções, fundamentam-se nos pilares das teorias socioeconômicas que sustentam a proposição do desenvolvimento sustentável.

Partir desta contextualização significa inserir o objeto de estudo desta tese no debate que nega a dissociação entre crescimento econômico e desenvolvimento. Além de entender esses fenômenos como profundamente interligados, a moderna noção de desenvolvimento sustentável busca superar o dilema semântico que reveste seus conceitos de origem: crescimento e desenvolvimento. O desenvolvimento sustentável abarcaria, então, as faces econômica, social, ambiental e cultural do desenvolvimento, propondo que tais dimensões (e outras, conforme o autor) são indissociáveis dos pontos de vista analítico, conceitual e prático.

A fundamentação deste estudo é construída, ainda, a partir do arcabouço teórico no qual se baseiam a prática do empreendedorismo social e a reflexão sobre o papel que ele desempenha na sociedade contemporânea. Ao conjugar inovação, articulação intersetorial e geração de valor social, o empreendedorismo social emerge como uma reinvenção do capitalismo, com a promessa de torná-lo socialmente mais justo, mais sustentável.

Esses conceitos e pressupostos são apresentados e discutidos a seguir.

\subsection{Desenvolvimento Social}

\subsubsection{O Desenvolvimento Social no contexto do Desenvolvimento Sustentável}

O desenvolvimento do capitalismo como sistema político-econômico dominante em nosso planeta levou à consolidação do pressuposto de que o crescimento econômico deveria ser a meta única das nações, ainda que isso custasse o uso ilimitado de recursos naturais e o baixo investimento no bem-estar social. As noções de desenvolvimento e de crescimento econômico não eram distintas até a década de 1960, pois as poucas nações desenvolvidas eram 
justamente as que haviam enriquecido através da industrialização. Mas a posterior constatação de que o intenso crescimento econômico ocorrido a partir da década de 1950 em diversos países semi-industrializados (entre os quais o Brasil) não se traduziu necessariamente em maior acesso à saúde e à educação, deu origem a um intenso debate internacional sobre o sentido do vocábulo desenvolvimento (VEIGA, 2005a).

De modo geral, seja qual for o ângulo do debate, no cerne da ideia de desenvolvimento está o dilema da desigualdade:

No contexto histórico em que surgiu, a ideia de desenvolvimento implica a expiação e a reparação de desigualdades passadas, criando uma conexão capaz de preencher o abismo civilizatório entre as antigas nações metropolitanas e a sua antiga periferia colonial, entre as minorias ricas modernizadas e a maioria ainda atrasada e exausta dos trabalhadores pobres. O desenvolvimento traz consigo a promessa de tudo - a modernidade inclusiva propiciada pela mudança estrutural. (SACHS, 2004, p.13).

As proposições acerca do desenvolvimento podem ser aglutinadas em três principais linhas de pensamento. A primeira, orientada pela crença de que o crescimento econômico seria o propulsor do desenvolvimento, limitava-se a buscar respostas para três questões básicas: como, para quem e o quê produzir. Predominante até a década de 1960, essa abordagem privilegiava o crescimento econômico de um país, mensurado pelo crescimento do Produto Interno Bruto (PIB) e do nível de bem-estar de uma população conforme a Renda Per Capita (VEIGA, 2005a).

Dentro desta concepção de desenvolvimento, a "Teoria do Derrame", que coloca o crescimento econômico como propulsor natural das soluções para os problemas sociais, não teve comprovação prática em nenhum país. A história socioeconômica da América Latina é rica em exemplos sobre as consequências do seu emprego. A acumulação de capital como alavanca do crescimento, em detrimento de outros gastos ou investimentos, exigiu sacrifícios sociais que minaram as bases do crescimento sustentado. A exclusão do tema da iniquidade da agenda de debates sobre as linhas de desenvolvimento, ou sua aceitação como algo necessário para promoção do crescimento, gerou atrasos significativos no desenvolvimento, acompanhados por altos custos sociais e perda de eficiência macroeconômica. A crença de que gastos sociais, sobretudo os programas compensatórios, são custos quase totalmente 
improdutivos e menos importantes que outras formas de aplicação dos recursos, é comprovadamente aliada à baixa produtividade da população e ao seu baixo capital cognoscitivo. Além desses fatores, a marginalização dos temas cultura, solidariedade e perfil da sociedade tem sido recorrente na América Latina e também é importante fonte de bloqueio de soluções criativas e alternativas para a solução de mazelas sociais (KLIKSBERG, 1997).

Uma segunda linha de discussão coloca o desenvolvimento econômico como uma ilusão ou como algo inexequível (VEIGA, 2005a). Essa abordagem ainda associa desenvolvimento a crescimento econômico e, sobretudo, a riqueza. Um de seus principais expoentes, o economista italiano Giovanni Arrighi (1997) defende que os países periféricos não têm e nunca terão oportunidades de avanço econômico semelhantes às experimentadas pelos Estados situados no núcleo orgânico, ou seja, os países industrializados e ricos. Para ele, a riqueza não pode ser generalizada porque se baseia em processos relacionais de exploração e de exclusão que pressupõem a contínua reprodução de pobreza na maior parte da população mundial. Esse argumento é ampliado a partir da constatação do economista brasileiro Celso Furtado (1974), de que a importação de padrões culturais dos países centrais pelos países periféricos significa a adoção de modelos de consumo sem as necessárias transformações nas estruturas da economia e da sociedade que adotam essa modernização. Não havendo possibilidade de evolução deste sistema, o estilo de vida criado pelo capitalismo industrial sempre será privilégio de uma minoria. (FURTADO, 1974; VEIGA, 2010; CAVALCANTI, 2001).

Uma terceira abordagem atesta que os resultados do crescimento econômico não se traduzem automaticamente em benefícios, e coloca o desenvolvimento como um desejo coletivo de evolução e progresso (VEIGA, 2005a). Esse "caminho do meio" entre as duas linhas de pensamento expostas anteriormente baseia-se em especial nas proposições de Amartya Sen e Ignacy Sachs, segundo as quais o desenvolvimento consiste na remoção das fontes de privação de liberdade das pessoas. Ainda apoiando-se nas ideias de Celso Furtado, Veiga (2005a) observa que o desenvolvimento implica na transformação dos meios e dos fins do progresso material, dando suporte a uma abordagem mais próxima do debate atual sobre a redução das desigualdades associada à redução dos impactos no mundo físico/meio ambiente.

A problemática ambiental, que atualmente adquire crescente relevância dentre as proposições de desenvolvimento, antecedeu e acompanhou o debate sobre o crescimento econômico e 
desenvolvimento social. Ganhou força na década de 1970, dando origem à noção de ecodesenvolvimento cunhada por I. Sachs, posteriormente rebatizada como desenvolvimento sustentável.

A ideia de um desenvolvimento sustentável ganhou força em contraposição à supremacia do crescimento econômico, com a publicação do Relatório Brundtland (Nosso Futuro Comum) pela Comissão Mundial sobre Meio Ambiente e Desenvolvimento, em 1987. Essa proposta ganhou legitimidade e foi definitivamente incorporada à agenda global com as decisões tomadas na ECO-92, ou Conferência sobre Meio Ambiente e Desenvolvimento, realizada no Rio de Janeiro em 1992. Desde então, a definição mais conhecida e utilizada de desenvolvimento sustentável postula que:

A humanidade tem a capacidade de tornar o desenvolvimento sustentável - de garantir que ele atenda às necessidades do presente sem comprometer a capacidade das futuras gerações de atender às suas próprias necessidades. (CMMAD apud AGENDA 21, 1987).

No final do século XX, as formulações sobre a noção de desenvolvimento sustentável consolidaram-se em duas vertentes complementares: a do desenvolvimento, apresentado como um debate que busca afirmar a importância das questões sociais, extrapolando os tradicionais limites do crescimento econômico; e da sustentabilidade, um debate sobre a possibilidade de conciliação, ou não, entre crescimento econômico e preservação ambiental. Entre a primeira Conferência das Nações Unidas sobre Meio Ambiente, realizada em 1972, e a Cúpula sobre Desenvolvimento Sustentável, realizada em 2002, o conceito de desenvolvimento sustentável foi refinado e a "sustentabilidade social" tornou-se parte essencial dele. Ela encerra a ideia de que o crescimento econômico só se traduz em desenvolvimento quando gera empregos e contribui para a redução da pobreza e das desigualdades. (VEIGA, 2005a; SACHS, 2004).

Esse debate tem colocado em cheque o modelo de desenvolvimento ainda predominante na economia global que, como observa Zambam (2009), prioriza essencialmente o crescimento econômico, o aumento da produção e do consumo, o acesso às novas tecnologias e a expansão do comércio. $\mathrm{O}$ autor conclui que esse modelo: 
[...] não tem legitimidade moral porque limita a pessoa à condição de meio para a realização dos fins previamente planejados; utiliza indiscriminadamente os recursos naturais, sem a necessária avaliação dos impactos e das consequências para o equilíbrio ambiental e para as relações sociais, da mesma forma que inviabiliza as condições de existência segura das futuras gerações. (ZAMBAM, 2009, p.7).

Sachs (2009) vê na crise dos modelos econômicos clássicos a oportunidade para a construção de novos e plurais projetos. O fim do socialismo real, o fracasso do Consenso de Washington, a crise da social democracia e os resultados sociais drásticos da ênfase no crescimento econômico são, segundo o autor, ruínas de paradigmas sobre as quais deve se assentar a cultura do ecodesenvolvimento.

Nesse contexto, tanto o desenvolvimento quanto a sustentabilidade ambiental se colocam como dimensões relevantes do ponto de vista conceitual e do ponto de vista prático, embora ainda sejam debates marcados pela busca de evidências que fundamentem a construção de teorias e conceitos. São desafios que se colocam para policy makers nacionais e globais, influenciados por formulações desde as mais conservadoras até as mais alarmistas. E ambas as dimensões requerem urgência na adoção de novos conceitos e novas práticas (VEIGA, 2005a).

Alguns importantes esforços têm sido empreendidos para dar consistência a este debate. A complexa relação entre as dimensões econômica, ambiental e social é tida como central para promoção do desenvolvimento sustentável no relatório "Prosperity without growth?", publicado em 2009 pela Sustainable Development Commission. Esse relatório traz reforços para os argumentos fatalistas, que tendem a defender uma "condição estacionária" proposta por Daly (2002), em oposição à visão ultraotimista e a um “caminho do meio", possibilidades elencadas por Veiga (2005a) para compreensão do desenvolvimento sustentável.

Tendo como ponto central a ideia de prosperidade, a qual se mistura à noção de flourishing ${ }^{4}$, a linha que prega o "crescimento zero" ou o "de-crescimento" enfatiza a necessidade de mudanças nos atuais padrões de consumo para que o desenvolvimento sustentável seja alcançado. Defendendo mudanças estruturais que resultem em mudanças na lógica social do

\footnotetext{
${ }^{4}$ Muito próxima da ideia de A. Sen sobre desenvolvimento como expansão das capacidades de um indivíduo, "flourishing" é empregado no relatório com o sentido de prosperar, de adquirir melhor qualidade de vida, ainda que em detrimento da acumulação de riquezas e bens materiais.
} 
consumo, o relatório da Sustainable Development Commission (JACKSON, 2009) apresenta evidências de que pessoas com valores intrínsecos mais fortes do que valores materiais apresentam mais responsabilidade com o meio ambiente. $\mathrm{E}$ os impactos desse tipo de mudança iniciada na esfera social podem ser potencialmente grandes para o desenvolvimento sustentável. Se o consumo de mercadorias e novidades deixa de ser relevante para o funcionamento social, as pessoas se tornam capazes de saber o quanto é suficiente consumir, rompendo com o atual modelo baseado na produção crescente de bens e serviços, com seus consequentes impactos no meio-ambiente. O relatório prescreve que, para alcançar essa condição, é necessário desmantelar ou corrigir os incentivos dados atualmente para a insustentável e improdutiva competição por status que caracteriza as sociedades ocidentais. E é necessário estabelecer novas estruturas que proporcionem capacidades (capabilities) para que as pessoas prosperem (toflourish), principalmente para que participem plenamente da vida em sociedade de maneiras menos materialistas. (Ibid.).

Nesse contexto, os atuais padrões e modelos de crescimento econômico tornam-se duplamente antagônicos à promoção do desenvolvimento sustentável. De um lado, incentivam o uso irresponsável de recursos naturais, acelerando a sua degeneração. De outro, intensificam a pobreza e a desigualdade, perpetuando condições de vida que impedem a adoção de novos comportamentos, os quais provocariam, aceitariam ou reforçariam novas dinâmicas sociais e econômicas, fortalecendo a preservação dos recursos naturais.

Na abordagem pragmática do economista Ignacy Sachs, o crescimento econômico continua sendo necessário para o desenvolvimento, mas deve ser colocado a serviço de objetivos socialmente desejáveis e repensado de forma adequada, de modo a minimizar os impactos ambientais negativos:

O desenvolvimento sustentável obedece ao duplo imperativo ético da solidariedade com as gerações presentes e futuras, e exige a explicitação de critérios de sustentabilidade social e ambiental e de viabilidade econômica. Estritamente falando, apenas as soluções que considerem esses três elementos, isto é, que promovam o crescimento econômico com impactos positivos em termos sociais e ambientais, merecem a denominação de desenvolvimento. (SACHS, 2004, p. 36).

De acordo com esta visão, taxas significativas de crescimento são necessárias, pois é muito difícil redistribuir bens e renda numa economia estagnada. Para ele, a discussão sobre o 
“crescimento zero" ou o "de-crescimento", embora pertinente em países industrializados avançados, nos distrai quanto às prioridades nas urgências sociais dos países mais pobres. Nesses países, são centrais o acesso a oportunidades de trabalho remunerado e digno, a geração de riqueza e renda, a proteção e a participação sociais. O problema consiste em reconciliar os objetivos do progresso econômico com o imperativo de proporcionar oportunidades para todos. (SACHS, 2001, 2004; VECCHIATTI, 2004).

A visão de Sachs é reforçada por Sen (2004) ao observar que o desenvolvimento sustentável pressupõe responsabilidades assumidas e compartilhadas por todos os atores. A efetiva participação cidadã, que vai além do ativismo cívico, desperta a capacidade de pensar, avaliar e agir, colocando os seres humanos como agentes na criação de condições para a sustentabilidade do planeta. Nesse contexto, coloca a cidadania como uma importante liberdade a ser assegurada nas e pelas discussões sobre desenvolvimento sustentável: “A relevância da cidadania e da participação social não é apenas instrumental. Elas são parte integral daquilo que temos motivo para preservar." (SEN, 2004, p.16). Posteriormente, o economista salientou que a noção básica de desenvolvimento sustentável defendida a partir de Brundtland e seus seguidores, deve ser combinada com uma visão ampla dos seres humanos como agentes, cujas liberdades têm valor, e não apenas como recipientes reduzidos a padrões de vida (SEN, 2007).

Sachs (1993) propõe que o desenvolvimento sustentável está ancorado em cinco pilares: social, ambiental, econômico, territorial e cultural:

- Social: significa a busca pela equidade na geração de oportunidades e na distribuição de renda e de bens;

- Ambiental: refere-se à utilização de recursos naturais renováveis e de tecnologias adequadas, visando ao desestímulo e limitação do uso dos recursos não renováveis;

- Econômico: refere-se à alocação e gerenciamento eficientes dos recursos e de um fluxo contínuo de investimentos públicos e privados;

- Territorial: significa a busca por uma configuração de equilíbrio na distribuição espacial dos recursos, das populações rural e urbana, e das atividades;

- Cultural: relaciona-se à garantia de continuidade das tradições e pluralidade cultural dos povos, incluindo-se a criação e a manutenção do capital social. 
Em linha com as proposições de Sen (2000), Sachs (2004) posteriormente agregaria a dimensão política a esses pilares de construção e manutenção do desenvolvimento sustentável:

- Político: refere-se à existência de governança democrática para regulação dos mercados e à promoção de liberdades democráticas como instrumentos para que as mudanças necessárias efetivamente ocorram.

Para dar conta dessas dimensões, faz-se necessária uma visão integrada do mundo, com indicadores interdimensionais que mostrem as inter-relações entre economia, meio ambiente e sociedade. Ou seja, para sua aplicabilidade, a noção de desenvolvimento sustentável exige que os indicadores sociais, econômicos e ambientais sejam observados de modo interdependente e inter-relacionado (SACHS, 1993).

Por ocasião do evento Rio+20, que celebrou duas décadas de realização da ECO-92, também promovido na cidade do Rio de Janeiro, a discussão sobre indicadores que mensurem o desenvolvimento sustentável ganhou força. O PIB (Produto Interno Bruto) continua encabeçando a lista dos indicadores de desenvolvimento, mas as críticas ao reducionismo econômico e ao viés produtivista que ele representa têm alimentado a criação de propostas alternativas, as quais ganham consistência a cada ano. Marcovitch (2012) observa que as reflexões sobre o futuro global vêm relativizando o peso do PIB na caracterização do desenvolvimento, e outras formas de mensuração do desempenho dos países vêm sendo experimentadas. Algumas recomendações para superação do PIB como principal indicador de desenvolvimento incluem deslocar o foco de fatores produtivos para indicadores de renda e de consumo, os quais devem ser conjugados à riqueza e analisados sob uma perspectiva de distribuição (STIGLITZ; SEN; FITOUSSI, 2010; VEIGA, 2012).

Precursor das novas propostas de mensuração do desenvolvimento, o IDH (Índice de Desenvolvimento Humano) vem se consolidando como um indicador social que vai além da dimensão econômica mensurada pelo PIB. Composto por indicadores de educação, longevidade e PIB per capita, este índice completou 20 anos, e tem sido amplamente 
empregado pela ONU e por diversos países para retratar os avanços ou retrocessos sociais experimentados anualmente.

Durante a Rio+20, a ONU lançou uma métrica que contabiliza capital humano, uso de recursos naturais e produção industrial, o IRI (Índice de Riqueza Inclusiva). Em 2014, este indicador, que pretende agregar as dimensões econômica, social e ambiental, deverá incluir também o capital social. Sob a ótica destes indicadores, entre 1990 e 2008, o PIB do Brasil cresceu $1,6 \%$, o IDH cresceu $0,9 \%$ e o IRI experimentou $0,9 \%$ de crescimento. A China liderou todos os rankings: teve 9,6\% de crescimento do PIB, 1,7\% de crescimento do IDH e cresceu 2,1\% no IRI. (RIGHETTI, 2012)

\subsubsection{Desenvolvimento Social e Desenvolvimento Local}

O desenvolvimento social pode ser compreendido a partir da apropriação de três gerações de direitos humanos: direitos políticos, civis e cívicos; direitos econômicos, sociais e culturais; direitos coletivos ao meio ambiente e ao desenvolvimento. Com isso, igualdade, equidade e solidariedade são elementos embutidos no conceito de desenvolvimento. O objetivo maior deixa de ser a maximização do PIB e se torna a promoção da igualdade e a redução da pobreza, maximizando vantagens dos menos favorecidos. (SACHS, 2004).

Diversas teorias econômicas têm sido desenvolvidas e testadas, com o objetivo de promover a igualdade no acesso a recursos e a condições satisfatórias de vida para as camadas populacionais que ficam à margem dos benefícios propiciados pelo desenvolvimento econômico de um dado país ou uma dada região. Não é objetivo deste estudo aprofundar ou esgotar esse debate, mas sim buscar contribuições das teorias econômicas que permitam identificar quais elementos são indicativos de que um grupo de pessoas, uma comunidade ou um território experimentam ou experimentaram processos de desenvolvimento social, impulsionados ou fortalecidos pela ação de empreendimentos sociais. Dessa forma, o estudo busca aproximar teorias econômicas e administrativas, propondo-se a identificar como determinadas características organizacionais e de gestão de um tipo específico de empreendimento podem trazer contribuições para o desenvolvimento social. 
Para tanto, este estudo apoia-se nos pressupostos de que a promoção do desenvolvimento não se reduz a crescimento, de que a questão da desigualdade é central, mas nem desenvolvimento e nem desigualdade se limitam à renda. Essa visão, que rompe com a tradição neoclássica e economicista do desenvolvimento, é defendida pelo economista indiano Amartya Sen, ganhador do Prêmio Nobel de Economia em 1998, ao desenvolver uma teoria que busca responder: Qual a "relação entre rendas e realizações, entre mercadorias e capacidades, entre nossa riqueza econômica e nossa possibilidade de viver do modo como gostaríamos?" (SEN, 2000 p.27).

Para Sen (Ibid., p.28-29), é natural que o crescimento econômico e o aumento da renda sejam desejados. Entretanto, eles não devem ser considerados como fins em si mesmos. Para o autor, o desenvolvimento "está relacionado sobretudo com a melhora da vida que levamos e das liberdades de que desfrutamos" e, portanto, renda e riqueza são desejáveis unicamente porque são meios para adquirirmos "mais liberdade para levar o tipo de vida que temos razão para valorizar". Ou seja, o crescimento econômico constitui um dos meios para promoção do desenvolvimento. Este, por sua vez, significa a ampliação das liberdades substantivas através da remoção das condições que acarretam sua privação, num processo de expansão de capacidades. Por consequência, a pobreza é vista como uma privação de capacidades básicas, não se limitando a uma constatação de baixos níveis de renda, o qual constitui o critério tradicional de identificação desta condição.

Partindo de ampla análise sobre a questão da desigualdade, Sen $(2007,2008)$ observa que todas as teorias no campo econômico exigem a igualdade de algo, desde as defendidas pelas diversas correntes igualitaristas (de renda, de bem-estar, de recursos) até os utilitaristas, quando propõem a atribuição de pesos iguais aos interesses do conjunto de indivíduos. Entretanto, sua análise enfatiza que mesmo as abordagens mais comumente aceitas, como a que concebe a pobreza em termos de baixa renda, não reconhecem a diversidade que caracteriza as pessoas e os diferentes contextos em que vivem. Por essa razão, não dizem muito sobre o bem-estar. Sen (Ibid.) reconhece a importância do caráter descritivo que essas medidas tradicionais de pobreza assumem no exame da realidade. Mas assinala que, do ponto de vista programático, a discussão sobre desigualdade deve assentar-se sobre os diferentes graus de acesso a poder e a oportunidades. 
As oportunidades a que Sen (2008) se refere, nomeadas reais ou substantivas, envolvem mais do que a disponibilidade de recursos, embora a existência de meios econômicos insuficientes possa causar a privação de capacidades. $\mathrm{O}$ conceito relevante para a análise da pobreza tornase, nesta abordagem, a inadequação da renda, e não a comparação entre diferentes níveis de renda. Em obra lançada posteriormente, Sen (2007) sintetiza os principais elementos de sua concepção de desigualdade: disparidades na riqueza, assimetrias no poder e nas oportunidades políticas, sociais e econômicas. Assim, são as oportunidades que devem ser igualadas, no sentido de promover condições para que as pessoas realizem objetivos ligados ao seu bemestar em escolhas genuínas, ou seja, exercitem sua liberdade individual (SEN, 2008).

Uma importante implicação dessa concepção é que, ao colocar a expansão das liberdades individuais como objetivo do desenvolvimento, Sen $(2000,2007,2008)$ recoloca o crescimento econômico e o aumento de rendas individuais como meio, e não como fim em si mesmos. A expansão das liberdades econômicas, sociais e políticas seriam, por sua vez, a finalidade principal de todo e qualquer programa, público ou privado, na esfera do desenvolvimento social. Para isso, torna-se necessário remover condições que causam a privação de liberdades, como a desigualdade no acesso a alimentos, a serviços de saúde, a educação, além da ausência de direitos civis e democráticos.

Para Sen (2000), embora existam vários tipos de liberdades instrumentais que contribuem para que as pessoas possam viver do modo como desejariam, cinco delas merecem ênfase, por apontarem a necessidade de políticas específicas. São elas: liberdades políticas, facilidades econômicas, oportunidades sociais, garantias de transparência e segurança protetora. Embora distintos, estes tipos de liberdade vinculam-se e complementam-se. Por essa razão, a análise do desenvolvimento e a formulação de políticas públicas devem considerar a importância conjunta destas liberdades substantivas.

As liberdades políticas são as oportunidades que as pessoas têm para determinar quais serão seus governantes, quais princípios fundamentarão as ações dos governos e para fiscalizar e criticar as autoridades. São, também, as possibilidades de liberdade de expressão política, de voto e seleção de legisladores e executivos, de escolha entre alternativas partidárias, além de oportunidades de diálogo político e de uma imprensa sem censura. São os direitos políticos associados às democracias, em seu sentido mais abrangente. 
As facilidades econômicas são as oportunidades que as pessoas têm para utilizar recursos econômicos para consumo, produção ou troca. Essas oportunidades existem na medida em que o aumento de riqueza e renda do país se reflete no correspondente aumento de intitulamentos econômicos da população. Ou seja, as facilidades econômicas dependem em grande parte das condições distributivas ou do modo como as rendas adicionais são distribuídas.

As oportunidades sociais são as disposições existentes em áreas como educação e saúde. Relacionam-se a condições mais saudáveis de vida dos indivíduos, reduzindo a morbidez evitável e a morte prematura, e também à ampliação da possibilidade de participação em atividades econômicas e políticas, pela redução do analfabetismo.

As garantias de transparência são as garantias de sinceridade nas interações sociais, de dessegredo e clareza. Elas funcionam como inibidoras da corrupção, da irresponsabilidade financeira e de transações ilícitas.

Por fim, a segurança protetora envolve a rede de segurança social que impede que as pessoas venham a sucumbir frente a grandes privações, como a fome e o desemprego. Inclui disposições fixas, como benefícios para desempregados, suplementos de renda para indigentes, e também medidas ad hoc, como distribuição de alimentos e criação de empregos em casos emergenciais.

Para Sen (2000, p.33), o indivíduo assume papel central no processo de desenvolvimento: sua condição de agente, como "alguém que age e ocasiona mudança, e cujas realizações podem ser julgadas de acordo com seus próprios valores e objetivos" é vetor para as transformações sociais. Nesse contexto, a liberdade individual é um produto social que deriva de uma relação de "mão dupla entre (1) as disposições sociais que visam expandir as liberdades individuais e (2) o uso de liberdades individuais, não só para melhorar a vida de cada um, mas também para tornar as disposições sociais mais apropriadas e eficazes" (SEN, Ibid., p.46).

Comungando dessas propostas, o economista Ignacy Sachs vê no sentido do desenvolvimento a maximização de oportunidades que habilitem os seres humanos a manifestarem potencialidades, talentos e imaginação que tragam auto-realização e felicidade. Essas 
oportunidades podem ser criadas em empreendimentos individuais e coletivos combinados e em tempo dedicado a atividades não produtivas. A universalização e o exercício efetivo dos direitos humanos, princípios preconizados pela teoria de Sen, reafirmam a necessidade de que o direito ao trabalho seja central nas estratégias de promoção do desenvolvimento, uma vez que o trabalho decente abre caminho para o exercício de vários outros direitos. Nesse ambiente, a maximização de oportunidades ocorre com a produção de "meios de existência" que supram as necessidades materiais básicas da vida. (SACHS, 2004).

Para Sachs (Ibid.), promover a inclusão social "justa", rompendo com formas perversas, anormais e desiguais de inclusão social que impedem a apropriação efetiva da totalidade de direitos humanos, se converte em requisito central para o desenvolvimento. Esse "desenvolvimento includente" tem como valor fundamental o acesso de todos os cidadãos aos seguintes serviços públicos:

- Programas de assistência a minorias, voltados à compensação de desigualdades naturais ou físicas, e políticas sociais compensatórias financiadas pela redistribuição de renda;

- $\quad$ Acesso à educação de qualidade conjugada à erradicação do trabalho infantil;

- Programas de proteção à saúde que contemplem segurança alimentar, condições de saneamento básico e acesso a água potável, qualidade das condições de moradia e de trabalho, educação e medidas preventivas;

- $\quad$ Provisão de condições adequadas de moradia.

Do ponto de vista macroeconômico, existem evidências de que um vigoroso desenvolvimento social é fundamental para que possa haver crescimento econômico sustentado, e não o inverso. O economista argentino Bernardo Kliksberg $(1997,2003)$ argumenta que os casos de Israel, Canadá, Holanda e Bélgica exemplificam o êxito desta fórmula: o investimento em tecnologia e competitividade foi acompanhado por investimentos de grande alcance em campos como educação, saúde e nutrição. Sen (1996), citado por Kliksberg (1997), também observa que o papel da educação e da saúde foi fundamental na mudança social e econômica vivenciada no Leste e no Sudeste asiáticos.

Estudo realizado ao longo de quatro décadas com indicadores de iniquidade, citado por Kliksberg (Ibid.), conclui que a redução da desigualdade estimulou o crescimento no Sudeste 
Asiático, e que a permanência da desigualdade foi um grande obstáculo ao progresso na América Latina. Isso porque a redução da desigualdade contribui para a estabilidade política e macroeconômica, aumenta a eficiência dos trabalhadores de baixa renda, diminui a distância entre rendimentos rurais e rendimentos urbanos, e reduz a necessidade de instituições reguladoras nesse campo. Adicionalmente, Veiga (2012) argumenta que medidas para a erradicação da pobreza somente surtirão efeito em termos de desenvolvimento sustentável quando forem combinadas com discussões sobre as desigualdades.

Em muitos países da América Latina, ainda persistem os modelos de desenvolvimentos pautados pelo crescimento econômico e pela naturalização dos problemas sociais. Durante as últimas décadas do século XX, a forma equivocada de entender e formular políticas sociais alimentou falácias que agravaram ainda mais a desigualdade, a pobreza e todas as suas consequências no continente, como demonstram os estudos de Kliksberg (2003). A negação ou a relativização da pobreza, a falta de urgência na solução de carências básicas, a priorização quase absoluta do crescimento econômico, a naturalização da desigualdade, a falta de políticas sociais estruturantes, a maniqueização do Estado associada à incredulidade da força da sociedade civil, a baixa participação popular, problemas éticos e a desesperança frente a esse jogo de forças são fatores que reforçam estruturalmente a pobreza e precisam ser combatidos em sua origem para que o desenvolvimento social seja efetivamente promovido (OLIVEIRA, 2004a; KLIKSBERG, 2003).

No campo das políticas econômicas, alguns autores defendem que o principal alavancador de redução da desigualdade seria a existência de uma renda básica universal (universal basic income - UBI), cujo valor deveria ser o mínimo necessário para a subsistência de seu receptor. Essa renda básica serviria como um potente instrumento de justiça social, pois promoveria a liberdade real para todos, ao proporcionar os recursos materiais necessários para que as pessoas busquem seus objetivos. Ao mesmo tempo, essa renda básica ajudaria a solucionar os dilemas da política de pobreza e desemprego, além de servir aos ideais de grupos compostos por minorias, como os movimentos feministas e verdes. (VAN PARIJS, 2000).

Sachs (2004) defende a ideia, segundo ele apoiada pelo Nobel de Economia J. Stiglitz, de que as políticas compensatórias de distribuição de renda no sistema fiscal são necessárias, mas 
menos efetivas do que as políticas de emprego que mudam a distribuição de renda primária. Para ele, na perspectiva do desenvolvimento, o fomento do emprego deve ser preferido às políticas assistencialistas, pois ele confere soluções mais duradoras com a geração de renda, além de proporcionar mais dignidade, proveniente do próprio emprego.

Especialmente em países onde a dimensão social do desenvolvimento sustentável é frágil, como se observa na América Latina como um todo, a geração de emprego ou de autoemprego e de renda, através de oportunidades de trabalho decente para todos, emerge como importante alavancador do desenvolvimento, ao movimentar o mercado interno. $\mathrm{O}$ direito ao trabalho digno é criticamente importante, por motivos intrínsecos e instrumentais. Com base nas proposições da OIT, Sachs (2004) defende que o "trabalho decente para todos", seja através do emprego ou do autoemprego, é central na construção de uma estratégia endógena de desenvolvimento, ancorada no aproveitamento das potencialidades do mercado interno nos países periféricos, com ênfase na mudança da distribuição primária de renda.

Kliksberg $(1997,2007)$ ressalta que a cultura também ocupa importante papel na promoção do desenvolvimento social. Geralmente tomada como um obstáculo à execução de programas sociais, por criar problemas inesperados às iniciativas "de cima para baixo", quando olhada sob outra perspectiva pode tornar-se ponto central na agenda de transformação. O capital cultural de uma população pode gerar respostas criativas e sintonizadas com os problemas concretos que vivencia; a atividade cultural é básica para promoção da articulação social, a qual é desejada na formulação, implementação e gestão de programas sociais; a ação cultural favorece o fortalecimento na unidade familiar, contribui fortemente para a elevação da autoestima, amplia o âmbito de ação do insuficiente ensino público, contribui para a prevenção da criminalidade e, por fim, tem função estratégica no fortalecimento efetivo do processo democrático: “A cultura dos pobres é capital social que, exponenciado, pode servir de base para a resposta a problemas sociais essenciais." (KLIKSBERG, 1997, p.34).

Associando essas duas proposições, as quais enfatizam a importância de emprego ou ocupação remunerada e do capital cultural na promoção do desenvolvimento, uma perspectiva que assume grande importância prática no contexto brasileiro diz respeito à existência de estratégias de desenvolvimento local. São iniciativas que visam propiciar transformação social, mobilizando potencialidades e recursos de uma determinada comunidade ou região, 
orientada para seu desenvolvimento econômico e social (BROSE, 2005; HADDAD, 2004; LOURENÇO, 2003).

O incentivo à criação de uma economia social está no cerne de muitas iniciativas de desenvolvimento local. O objetivo central seria o desenvolvimento de um ambiente favorável ao surgimento de formas de produção cuja relação com o mercado e com o Estado não seja baseada na acumulação capitalista, mas seja orientada pela lógica da sobrevivência e da solidariedade, como propõem os principais defensores da ideia de uma economia plural Laville, Coraggio e Singer (LEITE, 2009).

À frente da Secretária Nacional de Economia Solidária, o economista Paul Singer propõe que o desenvolvimento de comunidades pobres deve se dar através do desenvolvimento solidário, o qual beneficia a todos seus membros conjuntamente, "unidos pela ajuda mútua e pela posse coletiva de certos meios essenciais de produção ou distribuição". Otimista quanto ao futuro da economia social no Brasil, Singer considera que a organização de empreendimentos solidários representa o início de revoluções locais, que ocorrem nos níveis individual e social, e que mudam os relacionamentos entre atores envolvidos direta ou indiretamente na atividade produtiva - família, vizinhos, autoridades públicas, religiosas, intelectuais etc. (SINGER, 2004, p.3; LEITE, 2009)

Para Laville, as formas de produção baseadas na reciprocidade seriam resultantes de ações coletivas capazes de promover a solidariedade democrática e democratizar a economia. Laville observa que a relação entre as experiências de economia solidária e o desenvolvimento econômico local amplia o leque de benefícios proporcionados por cooperativas. O benefício social deixa de se restringir ao grupo dos cooperados internos e passa a ter impactos da organização na vida local. (FRANÇA FILHO; LAVILLE, 2004; LEITE, 2009).

No contexto brasileiro, muitas definições e metodologias acerca do desenvolvimento local vêm sendo discutidas. Em sua maioria, propõem duas características em comum: a ideia de que o desenvolvimento vai além da noção de crescimento econômico, estando relacionado à conquista e à garantia da cidadania como condição básica para que as pessoas conquistem bem-estar e melhoria da qualidade de vida. E a proposição de que o local é mais do que o 
espaço físico, no sentido de ser uma construção social onde as ações dos atores e das comunidades condicionam o espaço e por ele são condicionadas. No local, há a possibilidade de construção de um novo marco de regulação do mercado e da mediação social. (SILVA, 2010; COCCO; GALVÃO, 2001; OLIVEIRA, 2001).

O desenvolvimento local se coloca como uma estratégia de mitigação da pobreza através da mobilização de recursos locais. Aparentemente mais democráticas, mais eficazes e mais sustentáveis, as abordagens centradas na comunidade colocam-se como alternativas aos programas convencionais de socorro à pobreza. (GIDDENS, 1998 apud MOREIRA et al, 2003).

Esse processo implica, idealmente, na participação ativa dos agentes envolvidos no planejamento, na produção, na gestão das ações e recursos, através do envolvimento da comunidade desde o estudo e diagnóstico de sua situação (GOMES, 2005). "Desenvolvimento local significa a melhoria da qualidade de vida construída em um processo histórico pelas pessoas que ali vivem e seus filhos." (BROSE, 2005).

De acordo com Franco (2000), durante a década de 1990, o conceito de desenvolvimento local sustentável consolidou-se no Brasil e em outros países que compunham a periferia do capitalismo, fortalecendo a noção de território e propondo soluções para o enfrentamento mais efetivo da pobreza, da desigualdade e da exclusão socioeconômica. Sachs (2004) observa que esse processo de empoderamento das comunidades e a promoção da democracia direta são fundamentais para políticas de desenvolvimento e pode tornar-se um novo paradigma de economias mistas baseadas no diálogo, nas negociações e nos contratos entre os diferentes atores envolvidos como desenvolvimento.

Compreender o desenvolvimento como um processo local leva ao resgate de dimensões esquecidas por abordagens globais: a identidade, a dinâmica própria e as especificidades que mantêm as relações de interdependência com áreas mais vastas. Dessa forma, o desenvolvimento local vai além de âmbitos empresariais, governamentais e da sociedade civil, construindo um sentido de comunidade local, estruturado sobre a construção de uma identidade territorial. Para que este dinamismo das relações possa fluir, deve-se prospectar a disponibilidade de recursos econômicos, humanos, institucionais, ambientais e culturais, além de economias de escala não exploradas nas localidades e territórios, passíveis de constituir seu 
potencial de inovação e desenvolvimento, gerando riqueza e qualidade de vida para a população local (BRITO; ZAPATA, 2004).

O desenvolvimento local sustentável pressupõe participação de diversos atores, acesso a informações e facilidades de comunicação necessárias para garantir a existência de laços entre os diferentes grupos e a criação de capacidade coletiva. Esse contexto ressalta a importância de conceber e implantar novos modelos de desenvolvimento que impliquem na participação de toda a sociedade e na expansão do empreendedorismo social, entendido como uma iniciativa da sociedade civil a fim de influir nos processos de geração de valor social através da inovação e gestão. Este processo começa por induzir as comunidades ao exercício de diagnosticar sua realidade e projetar visões de futuro, com base em seus talentos e ativos sociais. A principal finalidade é facilitar o processo de significação e transformação da comunidade, o que lhe permite conceber cenários de vida futura e de gestão social do seu desenvolvimento (ARNS et al, 2003). É neste ponto que o dinamismo, associado ao empreendedorismo social, pode desempenhar papel fundamental para a promoção integral do desenvolvimento econômico e social comunitário.

A existência ou a construção de capital social tem sido apontada como importante alicerce para a promoção do desenvolvimento local (MILANI, 2003). Argumentando que o desenvolvimento não está associado exclusivamente a indicadores macroeconômicos, Kliksberg (2007, p.304) observa que a ideia de capital social abre uma perspectiva muito mais ampla dentro da discussão sobre formas de promoção do desenvolvimento, habitando "processos silenciosos que se realizam no interior da sociedade".

O clássico estudo conduzido por Putnam (1996) sobre o tema demonstrou que a participação cidadã dos indivíduos é um dos elementos mais importantes para a construção da democracia e de uma sociedade sustentável. O estudo concluiu que a cultura de associação, característica do norte italiano, promovia e estimulava a confiança, essencial para se criar a participação cidadã e o cuidado com a coisa pública. Essa cultura gerava o capital social, ou seja, a capacidade de pessoas ou comunidades estabelecerem relações e vínculos entre si. Dessa forma, a participação seria estimulada a partir da criação de confiança entre os membros de uma comunidade. 
As definições mais difundidas de capital social, apresentadas por Coleman e por Putnam fundamentam-se em três características principais: a existência de redes e do associativismo, de normas e sanções, e de confiança intrínseca às relações (ALBAGLI; MACIEL, 2002). Kliksberg $(2003$, 2007) assinala que a cultura está por trás desses componentes básicos e ressalta, ainda, a presença do civismo e dos valores éticos. Bourdieu ressalta os aspectos inerentes à participação em redes de relações e acrescenta que aí é observada a existência do conflito, pois o capital social, assim como todas as demais formas de capital, é distribuído de forma desigual (ALBAGLI; MACIEL, op. cit.).

Em sentido mais amplo, o capital social é composto, dentre outros aspectos, pela capacidade de construir um projeto nacional compartilhado, de cultivar valores comuns, de preservar e fortalecer a cultura local, de construir instituições eficientes e flexíveis, de criar entendimento e cooperação (KLIKSBERG, 1997).

O capital social gera diversos benefícios econômicos. As relações de confiança, o espírito cooperativo, o compartilhamento de referências socioculturais e de objetivos comuns geram custos mais baixos, maior facilidade de compartilhamento de informações e conhecimentos. Os processos coletivos de tomada de decisões levam a maior estabilidade organizacional, melhor coordenação e coerência de ações. O conhecimento mútuo amplia a previsibilidade sobre o comportamento dos agentes, o que reduz a possibilidade de comportamentos oportunistas e favorece o compromisso em relação ao grupo. Ainda que isoladamente o capital social tenha efeito econômico limitado, ele pode desempenhar um importante papel de catalisador de mudanças sociais. Diversos estudos demonstram correlações entre a existência de capital social e maiores níveis de renda familiar, eficiência e qualidade das instituições e dos serviços públicos, rendimento escolar de crianças, e condições adequadas de saúde (ALBAGLI; MACIEL, 2002; KLIKSBERG, 2003, 2007).

Mais diretamente, o capital social cria um tipo de eficiência em uma dada comunidade, como os distritos industriais italianos inicialmente estudados por Putnam, que é profundamente social, mas que se transforma em valor econômico ao gerar eficiência produtiva, comercial ou empresarial. Os ativos intangíveis do capital social se transformam em ativos bastante tangíveis, como riqueza social, renda, produção. (SACHS; LAGES, 2001) 
Se, ainda que em conjunto com outros fatores, o capital social desempenha papéis fundamentais na promoção do desenvolvimento, sua marginalização ou degradação pode resultar em perturbações sociais que levam à perda da capacidade crítica para um crescimento sustentado. E o risco de redução ou destruição de capital social é maior para a população pobre. Estudos apontam que a desigualdade elevada deteriora o capital social e demonstram que pessoas com mais recursos econômicos mantêm relações de cooperação com mais estabilidade do que pessoas que enfrentam situações de crise e se veem impossibilitadas de cumprir as obrigações de reciprocidade. (KLIKSBERG, 1997, 2003, 2007).

Baseando-se no informe da Comissão Mundial de Cultura e Desenvolvimento da UNESCO de 1996, Kliksberg (2003) propõe que as inter-relações entre cultura, capital social e desenvolvimento precisam ser mais valorizadas, sobretudo na luta contra a pobreza. Promover a utilização de saberes, tradições, relações entre os homens e com a natureza tem como resultado a elevação da autoestima e o fortalecimento da identidade coletiva, a integração social e o cultivo de valores de cooperação e solidariedade.

Conclui-se que, no contexto brasileiro, a promoção do desenvolvimento social, ancorada em estratégias de desenvolvimento local que fomentem a cidadania e a democracia, a aceleração das economias locais, e o fortalecimento do capital social, pode ser um caminho viável e factível para a redução da desigualdade, entendida como a expansão de capacidades e liberdades individuais. Essa perspectiva pode ser sintetizada da seguinte forma:

\footnotetext{
Apenas uma nova socioeconomia - que crie empregos produtivos, crie oportunidades reais para que os trabalhadores informais possam passar à economia formal, invista vigorosamente em saúde e educação, amplie e potencialize as possibilidades produtivas dos pobres, promova e facilite sua articulação social e sua organização, e privilegie as crianças e as mulheres - poderá reverter o atual quadro de enfraquecimento do tecido social. (KLIKSBERG, 1997, p. 46).
}

No contexto do desenvolvimento sustentável, essa abordagem implica no entendimento de que a dimensão social inerente ao conceito de desenvolvimento sustentável não diz respeito apenas ao estabelecimento de limites ou restrições à persistência do desenvolvimento, mas implica na ultrapassagem do econômico: não pela rejeição da eficiência econômica e nem pela abdicação do crescimento econômico, mas pela colocação deles a serviço de um novo projeto societário, onde a finalidade social esteja justificada pelo postulado ético de 
solidariedade intrageracional e de equidade, materializada em um contrato social. (GONÇALVES, 2005; SACHS, 1995 apud GONÇALVES, 2005)

\subsection{Empreendedorismo Social}

\subsubsection{Resgate Histórico do Conceito}

O conceito de empreendedorismo social é bastante novo, ainda muito abrangente e impreciso, mas aplica-se a um fenômeno cujas raízes estão fincadas no florescimento do próprio sistema capitalista de produção, que é a identificação do empreendedor como importante agente econômico.

A figura do empreendedor é apresentada pela primeira vez em meio à transição do mercantilismo para o capitalismo, sob forte influência do pensamento liberal em construção à época, na obra "Ensaio sobre a Natureza do Comércio em Geral" de 1755, escrita pelo banqueiro e investidor internacional Richard Cantillon. As ideias expressas nessa obra ganharam destaque á época, sendo o próprio Cantillon considerado importante precursor de Adam Smith. Sob influência de sua experiência como investidor internacional na busca de nichos para o desenvolvimento de negócios lucrativos em plena Revolução Industrial, Cantillon descreve o empreendedor como o empresário que assume riscos na busca de lucro, adquirindo insumos a um preço certo para revendê-los a preços incertos. A predisposição para assumir riscos em condições de incerteza, associada à capacidade de inovar à procura de lucro são as características marcantes do empreendedor de Cantillon, e reforçaram o ideário dos pensadores liberais da época. (ROSAS, 2006; VEIGA, 2005b).

Dentro da tradição liberal de Cantillon e sob forte influência da obra de Adam Smith, "A Riqueza das Nações", o economista e professor francês Jean-Baptiste Say reintroduziu a importância da figura do empreendedor na obra "Tratado de Economia Política", publicada em 1803. Naquela obra, ele descreve o empreendedor como um quarto fator de produção, tão relevante quanto o capital, a terra e o trabalho. Para Say, o empreendedor tem papel essencial na dinâmica de crescimento da economia, tendo como principal característica a habilidade de reunir, planejar e combinar os diferentes meios de produção para oferecer novos bens. A 
partir dessa abordagem, o termo Entrepreneur passou a ser utilizado para designar pessoas que estimulavam o progresso econômico, buscando novas e diferentes formas de fazer as coisas. (SAY, 1803 apud ROSAS, 2006; GOMES, 2005; DEES, 2001).

A inovação como característica fundamental do empreendedorismo volta a ser ressaltada pelo economista austríaco Joseph Alois Schumpeter, a quem são atribuídas a difusão e a consolidação da noção de empreendedorismo como motor do desenvolvimento econômico. Na obra "Teoria do Desenvolvimento Econômico", publicada em 1911, Schumpeter propõe que o funcionamento dos mercados capitalistas não é determinado pelos fundamentos de equilíbrio geral e mercados perfeitamente competitivos (DEES, 2001; GOMES, 2005; FILLION, s.d.). No modelo de Schumpeter, as inovações introduzidas pelos empreendedores rompem o equilíbrio da economia e determinam a dinâmica do capitalismo, definindo novos espaços econômicos. Essas inovações podem ser de cinco tipos: (1) introdução de novos produtos ou serviços, ou de novas qualidades a esses; (2) introdução de novas formas de produção; (3) abertura de novos mercados; (4) exploração de novas fontes de matéria-prima ou novas formas de exploração; (5) reorganização do mercado ou surgimento de novas formas de exploração comercial (BULL; WILLARD, 1993; SCHUMPETER, 1934 apud EHLERS, 2003).

Schumpeter propõe que os empresários empreendedores são os principais agentes da destruição criadora do capitalismo, na medida em que rompem com o equilíbrio preexistente em mercados e em modelos organizacionais. Para isso, o empreendedor utiliza intensamente a criatividade e a intuição. Sua motivação resultado desejo de conquista e do prazer que decorre da criação e da realização. (SCHUMPETER, 1976).

Em 1921, na obra "Risco, Lucro e Incerteza", o economista Frank Knight retoma as ideias de Cantillon, destacando o risco como principal característica da ação empreendedora, em conjunto com a capacidade de antecipar mudanças e identificar oportunidades de negócios (EHLERS, 2003; ROSAS, 2006).

Esses conceitos influenciaram a economia mundial ao longo do século XX, sobretudo no pósguerra, quando a demanda por bens e serviços foi intensificada e gerou aumento da produção e da competitividade. Desde Schumpeter e Knight, entretanto, não houve contribuições 
relevantes quanto às relações entre empreendedorismo e desenvolvimento econômico. Apenas em 1973, o professor norte-americano Israel M. Kirzner, filiado à Escola Austríaca de Economia, resgata o tema ao publicar a obra "Empreendedorismo e Competitividade". De acordo com Kirzner, em mercados competitivos, o empreendedor identifica oportunidades de lucro aproveitando falhas de mercado. (EHLERS, 2003; ROSAS, 2006).

Ao longo das décadas de 1970 a 1990, os empreendedores passaram a ser investigados também no campo das ciências do comportamento. Sob influência dos estudos realizados pelo psicólogo norte-americano David McClelland, psicólogos behavioristas desenvolveram inúmeras pesquisas acerca das características de personalidade que diferenciam os empreendedores. Não houve consenso sobre qual seria esse perfil e os resultados se mostraram contraditórios, pois há distintos tipos e categorias de empreendedores, os quais atuam em áreas diversificadas que requerem atributos diferenciados (FILLION, s.d.).

A falta de consenso sobre a função empreendedora também no âmbito das ciências econômicas é ressaltada por Fillion:

Vários tentaram teorizar em torno do fenômeno, mas não existe ainda nenhuma teoria econômica sobre o empreendedor que reúna consenso, nem modelo econômico que explique o desenvolvimento a partir da função empreendedora, pois esta é dificilmente quantificável. (FILLION, s.d., p.5).

Além da falta de consenso na economia e na psicologia, o tema empreendedorismo comporta uma infinidade de definições e conceitos propostos por pesquisadores de diversos outros campos do conhecimento, que passaram a estudar o fenômeno, sobretudo a partir da década de 1990 (FILLION, s.d.; GOMES, 2005). No campo da gestão empresarial, por exemplo, Peter Drucker (1985) propõe um conceito abrangente, descrevendo os empreendedores como agentes que identificam, reagem e exploram mudanças como oportunidades para a geração de valor.

\subsubsection{O Empreendedorismo Social}

O crescente processo de exclusão social em todo o mundo, agravado pelas recentes crises econômicas globais, evidencia a incapacidade dos governos para, isoladamente, lidar com as 
grandes questões sociais. Esses fatores são grandes impulsores do surgimento e crescimento das organizações do Terceiro Setor e do conceito e da prática do empreendedorismo social (FISCHER, 2002; OLIVEIRA, 2004a).

O empreendedorismo social emerge como uma dentre várias propostas de enfrentamento à pobreza e expressões da questão social face ao contexto da sociedade globalizada. Insere-se, portanto, em uma realidade paradoxal e complexa (OLIVEIRA, 2003). Pode ser entendido como o resultado de um conjunto de transformações inter-relacionadas, ocorridas nas últimas duas a três décadas e citadas por Albagli e Maciel (2002, p.2): o declínio dos níveis de emprego e a apologia do autoemprego, concomitantemente à ascendência da ideologia neoliberal de redução do Estado; o aprofundamento do processo de globalização e o acirramento da competição capitalista; o avanço na organização da sociedade civil e a maior pressão pelo "empoderamento" de segmentos sociais excluídos e regiões marginalizadas.

A figura do empreendedor social emerge, então, como a liderança capaz de reunir recursos individuais, privados e coletivos para viabilizar o desenvolvimento e a implantação de soluções aos problemas sociais crônicos:

\footnotetext{
São pessoas que percebem onde há uma oportunidade para satisfazer algumas necessidades que o sistema social do Estado não vai ou não pode alcançar, e que captam coletivamente os recursos necessários (geralmente pessoas, às vezes voluntários, dinheiro e premissas) e os usam para "fazer a diferença”. (THOMPSON et al., 2000, apud JOHNSON, 2000, p.5).
}

Dessa forma, sobretudo por volta da década de 1990, as definições acerca do comportamento empreendedor ou da função empreendedora passam a ser transpostas da esfera das atividades econômicas e empresariais para a esfera das atividades sociais.

Embora o termo Empreendedor Social tenha sido discutido e conceituado por diversos autores, de diferentes linhas de pensamento e campos do conhecimento, sua difusão é atribuída a Bill Drayton, fundador e atual presidente da Ashoka. ${ }^{5}$ As características

\footnotetext{
${ }^{5}$ Criada em 1980 pelo norte-americano Bill Drayton, a Ashoka é uma organização mundial, sem fins lucrativos, pioneira no campo da inovação social, trabalho e apoio aos empreendedores sociais. Está presente em mais de 60 países, dentre eles o Brasil, desde 1986. Disponível em: <http://www.ashoka.org.br/sobre-a-ashoka/quemsomos/> Acesso em 03/08/2011.
} 
sintetizadas por Drayton enfatizam uma combinação de pragmatismo, compromisso com resultados e visão de futuro para realizar transformações sociais:

O Empreendedor Social aponta tendências e traz soluções inovadoras para problemas sociais e ambientais, seja por enxergar um problema que ainda não é reconhecido pela sociedade e/ou por vê-lo por meio de uma perspectiva diferenciada. Por meio da sua atuação, ele (a) acelera o processo de mudanças e inspira outros atores a se engajarem em torno de uma causa comum. (ASHOKA, 2011)

$\mathrm{Na}$ última década do século XX, a mobilização de pessoas e organizações em torno de questões socioambientais intensificou-se e adquiriu mais visibilidade, propiciando a identificação de traços comuns a tais iniciativas, inserindo-as no contexto do empreendedorismo social. Passaram a ser reconhecidos como empreendedores sociais as pessoas ou os grupos que identificam oportunidades para gerar mudanças sociais, com visão estratégica, ações inovadoras, efetividade de resultados e transparência de gestão (FISCHER, 2011; DEES, 2001).

Para os empreendedores sociais, a missão social é central e explícita. E obviamente, isso afeta a maneira como os empreendedores sociais percebem e avaliam as oportunidades. A criação central torna-se o impacto relativo à missão e não a riqueza. Para os empreendedores sociais a riqueza é apenas um meio para um determinado fim. (DEES, 2001, p.3).

Com foco na criação de valor social de forma sustentada e de amplo impacto, filantropos, líderes comunitários e ativistas passaram a ser considerados "empreendedores" pelo perfil de competências e por sua atuação criativa e inovadora, à semelhança dos empresários que gestam negócios. A diferença entre o empreendedor social e o empreendedor clássico reside na proposição de valor, ou seja, na motivação coletiva e no valor social que orienta sua ação inovadora. Trata-se de uma forma de catalisar a transformação social, indo além da promoção de pequenas mudanças no curto prazo, orientando o seu foco para os sistemas existentes, objetivando catalisar mudanças mais amplas no longo prazo. (ALVORD et al, 2002; VERNIS; IGLESIAS, 2010; FISCHER 2011).

As empresas criadas por empreendedores sociais podem gerar receita e podem ser com fins lucrativos ou sem fins lucrativos. O que realmente diferencia o empreendedor social é a primazia do benefício social. (MARTIN; OSBERG, 2007, p35). 
Consideradas essas características, o empreendedorismo social emerge como uma abordagem inovadora para lidar com necessidades sociais complexas através de iniciativas que tenham a criação de valor social como seu principal objetivo estratégico e que orientem sua missão de modo criativo e inovador (NICHOLLS, 2006; JOHNSON, 2000). Para isso, a figura do empreendedor social parece ser central, como assinala Hartingan:

Um empreendedor social é um tipo diferente de líder social que, entre outras coisas, aplica soluções práticas a problemas sociais através da combinação de inovação, disponibilização de recursos e oportunidade. A inovação do empreendedor social pode estar em um novo produto, serviço ou abordagem para um problema social. E este empreendedor concentra-se principalmente na criação de valores sociais, a despeito de sua empresa ser legalmente constituída como lucrativa ou não; além de se reportar totalmente à entidade à qual serve. (UNIVERSIAKNOWLEDGE@WHARTON, 2005).

As definições empregadas para caracterizar o empreendedor social por alguns dos mais relevantes atores institucionais do mundo, ligados a este fenômeno, foram elencadas por Oliveira (2004b). ${ }^{6}$ A análise destas proposições permite identificar que, idealmente, os empreendedores sociais compartilham as seguintes características:

- Podem ser oriundos ou ligados a setores lucrativos, não lucrativos ou públicos e destacam-se pela criatividade, determinação e foco na inovação social;

- São visionários com sentido prático, cuja motivação é a melhoria de vida das pessoas;

- Conciliam o pragmatismo empresarial com habilidades profissionais e com a busca de benefícios sociais;

- Combinam risco e valor com critério e sabedoria;

- Desenvolvem ideias, procedimentos e serviços para resolver problemas sociais;

- Buscam promover mudanças sociais de longo alcance em seus campos de atividade;

- Criam parcerias e alianças estratégicas para promover transformações sociais e para sustentar a iniciativa;

- Suas iniciativas buscam emancipar as pessoas, tornando-as menos dependentes do governo e da caridade.

\footnotetext{
${ }^{6}$ School Social Entrepreneurship- SSE, ReinoUnido; Canadian Center Social Entrepreneurship- CCSE, Canadá; Schwab Foundation, Suíça; The Institute Social Entrepreneurs- ISE, EUA; Ashoka, EUA; Erwing Marion, Kauffman Foundation, EUA.
} 
As definições mais difundidas no Brasil, também sistematizadas por Oliveira (2004b) ${ }^{7}$, têm suas características fundamentais sintetizadas no conceito desenvolvido por ASHOKA Empreendedores Sociais:

Os empreendedores sociais possuem características distintas dos empreendedores de negócios. Eles criam valores sociais pela inovação, pela força de recursos financeiros em prol do desenvolvimento social, econômico e comunitário. Alguns dos fundamentos básicos do empreendedorismo social estão diretamente ligados ao empreendedor social, destacando-se a sinceridade, paixão pelo que faz, clareza, confiança pessoal, valores centralizados, boa vontade de planejamento, capacidade de sonhar e habilidade para o improviso. (ODARA, 2011, p.3).

O empreendedorismo social pode se caracterizar, ainda, pela intervenção social através da criação de formas alternativas de produção econômica associada à participação social e democrática (GODÓI-DE-SOUZA, 2010). As capacidades de inovação, de identificação e de aproveitamento de oportunidades para a criação de novos negócios, novos mercados e capital social estariam a serviço da geração concomitante de valores social e econômico. Para tanto, não existe um modelo a ser seguido; a forma organizativa de um empreendimento social deve ser baseada no formato mais eficaz de mobilizar os recursos necessários para enfrentamento dos problemas sociais. (QUINTÃO, 2004; SEKN, 2006; GODÓI-DE-SOUZA, 2010; FISCHER, 2011).

Sob o prisma da geração concomitante de valores social e econômico, no Brasil coexistem iniciativas que se caracterizam como empreendimentos solidários e aquelas identificadas como negócios sociais. No primeiro caso, este conceito está mais próximo das práticas e ideias fundamentadas na literatura acerca da Economia Solidária. Muitas vezes, também é utilizado em abordagens normativas voltadas para a modernização da gestão de organizações sem fins lucrativos. Já os negócios sociais podem ser identificados como "empresas que, através da sua atividade principal, oferecem soluções para problemas sociais, utilizando mecanismos de mercado" (ARTEMÍSIA, 2012)

Independentemente do foco e do tipo de estruturação do empreendimento social, as definições apresentadas são expressão de uma literatura que se arrisca a idealizar e supervalorizar os atributos e o papel do empreendedorismo social frente à complexidade que caracteriza a

\footnotetext{
${ }^{7}$ Leite; Ashoka Empreendedores Sociais; Melo Neto e Froes; Rao; Rouere e Pádua.
} 
realidade social na qual estas iniciativas operam. Essa abordagem atribui ao empreendedor social traços semelhantes aos que mitificam o "empresário de sucesso" do mundo capitalista, além de elevá-los ao patamar de novos arquitetos de uma realidade social idealizada (FISCHER, 2011; MARTIN, 2009).

Discute-se, ainda, que o sucesso associado à ideia do empreendedorismo social tem frequentemente levado ao obscurecimento do entendimento de sua realidade. Há o risco de apresentar-se como nova panaceia capaz de resolver magicamente os enormes problemas econômicos, morais e de gestão como os que enfrentamos nesta transição para além do capitalismo financeiro global (CASTELLS, 2010).

O idealismo que ainda permeia a construção de um quadro de características distintivas que definam e diferenciem os empreendimentos sociais gera problemas de ordem prática e metodológica. Em extensa revisão da literatura norte-americana sobre o tema, Johnson (2000) evidenciou a dificuldade em definir as características de um empreendimento social e suas fronteiras conceituais, sobretudo num momento em que a literatura sobre o tema ainda era ainda mais incipiente e a complexidade do conceito se mostrava muito presente. Passada uma década, a tarefa de delimitar iniciativas e atividades que podem ser caracterizadas como empreendimentos sociais continua árdua. Além disso, vários outros termos são utilizados para designar iniciativas e atividades que poderiam ser definidas como empreendimentos sociais, tais como empreendimentos sem fins lucrativos (non-profit enterprise), empreendimentos com propósitos sociais (social purpose venture), empreendimentos para o bem comum (communitywealth venture), empreendimentos filantrópicos (venture philanthropy), capitalismo caridoso ou inclusivo (caring capitalism), empresa social (social enterprise) e empreendedorismo cívico (civic entrepreneurship) (JOHNSON, 2000).

Observa-se que, entre países e regiões, também há grandes diferenças não só na apropriação e na aplicação do termo empreendedorismo social, como nas origens deste tipo de iniciativa. Em ampla pesquisa recentemente realizada em artigos acadêmicos sobre os temas empresas sociais, negócios inclusivos e negócios sociais, Moura (2011) e Comini (2011) identificaram três diferentes perspectivas acerca da origem e emprego da ideia de empreendedorismo social. 
A primeira vertente tem sua raiz na existência de uma economia social fortemente presente no contexto europeu. Cooperativas, sociedades de auxílio mútuo e associações são os empreendimentos característicos de um conceito que reforça o caráter coletivo e participativo. (REFICCO, 2006 apud MOURA, 2011). A abordagem acadêmica, predominante na Europa, enfatiza como características distintivas deste tipo de empreendimento social a participação dos beneficiários na tomada de decisão e o reinvestimento do lucro na própria organização para potencializar o crescimento e o impacto social. Esta visão tem como premissa a existência de constante tensão entre obtenção de resultados financeiros e sociais (COMINI, 2011).

A segunda vertente, norte-americana, caracteriza-se pela orientação de mercado para negócios privados dedicados a produzir bens e serviços com objetivos sociais. (YOUNG, 2009 apud MOURA, 2011). Naquele contexto, predominam a ambiguidade e a diversidade de situações na aplicação do termo, mas é possível observar o crescimento de iniciativas que possibilitam compatibilizar o modus operandi de uma corporação capitalista tradicional com valores sociais e ambientais característicos de empreendimentos sociais (COMINI, 2011). Essa perspectiva, a qual tem ganhado força no estudo do empreendedorismo social, busca enfatizar o uso de mecanismos de mercado para a obtenção de resultados sociais. De acordo com esta abordagem, empreendimentos sociais são iniciativas comercialmente viáveis e socialmente responsáveis, criadas a partir da identificação de oportunidades de mercado para desenvolver produtos ou serviços com objetivos sociais, e cujos excedentes financeiros são reinvestidos em projetos ou ações de intervenção social (BOSCHEE, 2001).

A literatura norte-americana tende a centralizar sua discussão na valorização dos atributos pessoais dos empreendedores sociais, em detrimentos das características dos empreendimentos existentes. Dentro desta vertente, os empreendedores são caracterizados como pessoas capazes de mudar a capacidade de performance de uma sociedade; uma nova geração de líderes que forjam novas e poderosas ligações nas intersecções entre negócios, governo e sociedade; pessoas que têm visão e recursos para promover mudanças sociais, aliando habilidade nos negócios ao desejo de mudanças sociais; dirigentes de organizações sem fins lucrativos atentos ao mercado, sem perder de vista sua missão (GENDRON, 1996; HENTON et al, 1997; SCHULYER, 1998; BOSCHEE, 1998 apud JOHNSON, 2000). 
Já a vertente asiática, cuja principal inspiração é o trabalho do Nobel indiano Muhammad Yunus, enfatiza os benefícios sociais das atividades de empresas privadas, sejam elas geridas por acionistas capitalistas, dispostos a abrir mão da maximização dos lucros que percebem, sejam geridas por grupos de pessoas em condições de vulnerabilidade social, que se apropriam dos lucros gerados. (YUNUS, 2007 apud MOURA, 2011). Ao lado da vertente asiática, Moura (Ibid.) coloca a perspectiva latino-americana, que tem enfatizado a criação de negócios com propósitos sociais que sejam lucrativos e sustentáveis financeiramente (MARQUES et al, 2010). A visão latino-americana e a visão asiática valorizam a forte preocupação com a redução da pobreza e a necessidade prática de impacto social positivo, efetivo e, sobretudo, de longo prazo (COMINI, 2011).

Fischer (2011) observa que a expressão "social enterprise" foi incorporada com relativa facilidade no âmbito anglo-saxônico, enquanto autores latino-americanos tendem a rejeitar a tradução do termo como "empresa social", considerando a expressão "empreendedorismo social" como mais apropriada. Essa diferenciação pode estar relacionada à heterogeneidade de empreendimentos sociais constituídos na América Latina, com predominância de um ou de outro tipo, conforme o contexto socioeconômico do país em que operam.

Na América Latina, figuram como empreendimentos sociais as cooperativas rurais e urbanas constituídas por famílias ou grupos indígenas no México e Equador; cooperativas de ecoconsumo que operam no Uruguai, na Argentina, México e Brasil; mercados de trocas solidárias existentes na Argentina, Colômbia, México e Brasil; ecovilas de autogestão solidária no Brasil; agências de finanças e microcrédito solidário na Bolívia, México, Peru e Brasil; instituições de educação cooperativa na Venezuela, Colômbia, Argentina e Brasil; agências públicas dedicadas à promoção dos empreendimentos sociais na Colômbia, Equador, Brasil, México e Argentina; bem como redes de comércio justo que operam em todo o continente (ARRUDA, 2004 apud GODÓI-DE-SOUZA, 2010).

A diversidade de iniciativas identificadas com o empreendedorismo social é amplificada pela grande quantidade de áreas nas quais elas se desenvolvem, destacando-se: 1. Educação e inclusão digital; 2. Moradia de baixo custo; 3. Reciclagem e indústrias limpas; 4. Agricultura e floresta; 5. Uso da água e energias alternativas; 6. Saúde e nutrição comunitárias; 7. Educação e alfabetização; 8. Diversidade e multiculturalismo; 9. Oportunidades para 
deficientes; 10. Serviços sociais em geral; 11. Apoio ao empreendedorismo e microcrédito; e 12. Direitos humanos (DEMIRDJIAN, 2007 apud NOVAES; GIL, 2009).

Do ponto de vista econômico, o empreendedorismo social tende a adquirir crescente importância. Em países como Colômbia, Equador e Nicarágua, os empreendimentos sociais constituem setor reconhecido da economia nacional. Os grupos informais que se desenvolveram na África alcançaram importância macroeconômica, assim como na França, Bélgica, Canadá e Estados Unidos. (LISBOA, 2009; GODÓI-DE-SOUZA, 2010)

Embora o vínculo entre o empreendedorismo social e o desenvolvimento de políticas econômicas não tenha sido suficientemente explorado pela literatura acadêmica, alguns estudos procuram mostrar como essas duas dimensões se influenciam mutuamente. Eles sinalizam que empreendimentos sociais são responsáveis pela criação de empregos para segmentos menos favorecidos social e economicamente; esses empreendimentos criam e ofertam bens e serviços complementares aos oferecidos pelos setores público e privado; também criam e fortalecem o capital social; e buscam promover a equidade através da realização de sua missão. Empreendimentos sociais ancoram-se nas economias locais para abordar problemas sociais e ambientais, e isso dinamiza a economia. (NAGLER, 2007; FULLER; UNIVERSIA-KNOWLEDGE@WHARTON, 2005)

Do ponto de vista do desenvolvimento local, o empreendedorismo social pode figurar como um "agente de desenvolvimento", conforme proposta de Singer (2004, p.4) para promoção do desenvolvimento comunitário. Nessa condição, os empreendimentos sociais teriam a missão de conscientizar a comunidade, sobretudo seus líderes, de que seu esforço conjunto, amparado por crédito assistido, assessoria técnica e acompanhamento sistemático, ao promover educação política, econômica e financeira, capacita esse grupo social para enfrentar os problemas reais, à medida que eles vão se colocando.

No decorrer do processo, instituições vão surgindo por meio das quais a comunidade se organiza para promover o seu desenvolvimento: assembleia de cidadãos, comissões para diferentes tarefas, empresas individuais, familiares, cooperativas e associações de diferentes naturezas. O poder público local poderá se associar ao processo e se fazer representar, quando necessário, em comitês mistos público-privados. (SINGER, 2004, p.4). 
Nesse contexto dinâmico, contemplando iniciativas e organizações de distintas naturezas e formatos, o empreendedorismo social parece emergir como um fenômeno contemporâneo de contraponto ao sistema econômico dominante. Ele congrega experiências que vêm se multiplicando há algum tempo em várias partes do mundo, como expressão de um movimento social que apresenta características sociológicas e políticas e propõe mudança da estrutura capitalista, não necessariamente revolucionária, mas com características reformistas. (MOREIRA et al, 2003; GODÓI-DE-SOUZA, 2010)

\subsubsection{Empreendimentos Sociais}

Empreendimentos sociais podem ser caracterizados por três componentes principais: (1) a capacidade de identificar um equilíbrio estável, mas inerentemente injusto que provoca a marginalização e exclusão de um segmento da humanidade, (2) a capacidade de identificar uma oportunidade nesse equilíbrio injusto e desenvolver uma proposição com valor social, e (3) a busca de medidas para conseguir um novo equilíbrio estável que libere ou alivie o sofrimento do grupo-alvo e mesmo da sociedade em geral. (MARTIN; OSBERG, 2007; MAKHLOUF, 2011).

São iniciativas que não se limitam ao espaço físico de uma organização formal. Eles adquirem diversos formatos, assumindo características tangíveis e intangíveis de localização, espaço, infraestrutura, recursos e modelos de gestão. Um dos principais fatores distintivos do empreendedorismo social é a sua vocação para reduzir fronteiras organizacionais e estreitar relações de colaboração, de modo que a ação resultante seja uma "simbiose" do desempenho dos atores aliados (SEKN, 2006).

Essa simbiose é um dos principais fatores geradores de valor, notadamente o social, o qual não deriva, simplesmente, da interação entre os indivíduos, mas das ações coletivas orientadas por uma consciência comunitária, as quais influenciam o sistema econômico e as relações de produção, como propôs Schumpeter (1908-9) no início do século XX.

Por decorrência da organicidade sistêmica que caracteriza os empreendimentos sociais, constata-se que uma das principais características deste tipo de organização é um entrelaçamento entre as dimensões política, econômica e social. Paradoxalmente, um dos 
maiores desafios enfrentados por este tipo de empreendimento no Brasil é a criação de contextos favoráveis a essa organização socioeconômica e política entre cidadãos, uma vez que seus empreendedores compartilham mais carências do que recursos para criar e sustentar iniciativas de tamanha complexidade (GODÓI-DE-SOUZA, 2010).

Com sua ênfase na busca de soluções e na inovação social, empreendimentos sociais reduzem as tradicionais fronteiras entre os setores privado, público e o Terceiro Setor, e enfatizam modelos híbridos de atividades com e sem fins lucrativos. Promover a colaboração entre setores é inerente ao empreendedorismo social, assim como o desenvolvimento de novas e radicais abordagens para resolver antigos problemas. Essa conceituação sugere que, formalmente, empreendimentos sociais podem assumir uma grande variedade de formatos, incluindo organizações sem fins lucrativos, negócios com finalidades sociais (como bancos de desenvolvimento) e organizações híbridas que conjugam atividades com e sem fins lucrativos (como cooperativas de catadores de materiais recicláveis) (DEES, 2001; JOHNSON, 2000).

Desde a década de 1990, pesquisas centradas na colaboração intersetorial vêm sendo desenvolvidas em diversas partes do mundo e sinalizam que embora as parcerias entre empresas, organizações sem fins lucrativos e instituições ou empresas públicas existam há décadas, sua formação tem sido intensificada recentemente nos diversos continentes. Dentre os fatores associados a esta expansão estão a revisão dos papéis desempenhados pelo Estado, aliada à globalização econômica, o crescimento do número e das atividades desempenhadas pelas organizações da sociedade civil, e a disseminação de práticas vinculadas à responsabilidade social empresarial (FISCHER et.al., 2003). Austin (2001, p.17) caracteriza as alianças estratégicas como o resultado da migração progressiva das relações de cooperação tradicionalmente filantrópicas, estabelecidas entre organizações com e sem fins lucrativos, para "novas forma de trabalhar em conjunto para atingir seus objetivos e contribuir para a sociedade". O Copenhagen Centre utiliza o termo "new social partnerships" para caracterizar essas parcerias, pautadas pelo benefício mútuo e pela combinação de recursos e competências. (NELSON; ZADEK, 2001, p.14). O fortalecimento das alianças intersetoriais parece ter um contexto estimulante para a criação dos empreendimentos sociais.

A inexistência de fronteiras claras e a premência da colaboração entre atores distintos fazem com que os empreendimentos sociais se lancem para horizontes bem mais longínquos do que a filantropia ou a responsabilidade social. Elas buscam: incrementar o desenvolvimento 
socioambiental de localidades esquecidas pelo crescimento econômico capitalista; tornar a sociedade inclusiva para aqueles que foram despojados das condições físicas, sociais e econômicas necessárias a sua inserção como pessoas, consumidores e cidadãos; ampliar as oportunidades para que cada qual se emancipe por sua própria conta, gerando renda e tendo liberdade para escolher o estilo de vida que prefere e o destino que propiciará ao seu filho; assegurar que as próximas gerações tenham direito de nascer e viver em liberdade e com acesso aos recursos naturais que a biodiversidade oferece à vida humana (FISCHER, 2011).

Deste modo, as iniciativas empreendedoras descartam definitivamente os conceitos de assistencialismo e dependência, inserindo os de emancipação e cidadania. Não se trata apenas de modernização terminológica, mas de uma mudança radical nos valores que sustentam a atuação social. Pois não basta prover benesses; é preciso equalizar as condições sociais no que concerne à liberdade pessoal que, na visão de Amartya Sen (2000), é o fator condicionante para a existência de qualquer processo de desenvolvimento.

A construção de um novo paradigma para as organizações sociais a partir da transformação do assistencialismo em empreendedorismo é vista por alguns autores como o grande desafio contemporâneo para organizações que operam no campo social (COMMUNITY WEALTH VENTURES, 2003). Nesse contexto, o empreendedorismo social emerge como uma forte tendência associada à sobrevivência destas organizações, e a questão central passa a ser: as organizações sem fins lucrativos estão prontas para assumir o desafio do empreendedorismo social? Sob esta ótica, o empreendedorismo implica em uma mudança na cultura organizacional como extensão da oportunidade econômica, a qual torna a organização mais nítida e focada, capaz de "vender" ideias e ideais para um público muito mais amplo (STRICKLAND JR., 2003).

Atualmente, outra importante discussão no contexto do empreendedorismo social é a escala que o impacto dessas iniciativas pode alcançar. Empreendimentos sociais devem e podem causar mudanças em larga escala? Devem e podem influenciar políticas públicas? Como esse processo acontece?

Há muitos casos de empreendimentos sociais que criam mudanças em grande escala nos países em que operam, sobretudo em se tratando daqueles mais pobres e com equipamentos e 
políticas públicas insuficientes, como Haiti e muitos países da África e Índia. Isso pode levar alguns autores, como Osberg (2010), a citar exemplos desses países como a prova de que impactos de larga escala são inquestionáveis.

Outros argumentam que alguns empreendimentos alcançam mudanças em larga escala, mas são a exceção, não a regra. Com este olhar, Dees (2010) acrescenta que os benefícios do empreendedorismo social podem ser ampliados e aperfeiçoados, desde que o ecossistema seja favorável a isso. É necessário ter em mente a importância da cultura, da infraestrutura e do ambiente político em que os empreendedores sociais operam.

Quadir (2010), fundador de Grameenphone, empresa social que proporciona acesso a telefonia celular de baixo custo em Bangladesh, defende que apenas os empreendimentos com fins lucrativos têm a escala e o escopo necessários para solucionar as causas mais profundas dos problemas sociais. O lucro é necessário para conseguir escala e apenas os empreendimentos com fins lucrativos têm capacidade para enfrentar os problemas sociais.

Light (2010) questiona a capacidade que empreendedores sociais necessitam ter para alcançar mudanças em larga escala de uma forma suficientemente rápida para resolver as questões que ameaçam nosso mundo. Esse tipo de impacto, argumenta, só é possível através da construção de parcerias e alianças intersetoriais. Elkington (2010), por sua vez, reconhece que a força dos empreendedores sociais reside na conexão que mantêm com a comunidade e sua cultura. É profundamente cético a respeito de parcerias com empresas privadas, pelo risco de desvirtuamento dos empreendimentos sociais. E aponta que as iniciativas de algumas megaempresas, como Nike, Nestlé etc. têm potencial para gerar mudanças em escalas muito maiores do que os empreendimentos sociais mais expressivos. Isso porque a escala implica em mudanças sistêmicas em toda a economia, ou seja, a criação de um novo paradigma econômico.

Os empreendimentos sociais que atuam na América Latina têm dificuldade para gerar impactos de larga escala, e uma das causas deste fato pode ser o perfil do empreendedor que predomina no continente. Geralmente orientados para a busca de soluções locais e para a inovação, estes líderes criam soluções descasadas das políticas públicas e com baixo grau de replicabilidade. Por outro lado, tais empreendimentos apresentam alto potencial para geração 
de valor social, o qual pode ser definido como propõem os pesquisadores da rede SEKN (2006):

[...] a busca de progresso social por meio da remoção de barreiras que dificultam a inclusão, da ajuda àqueles temporariamente debilitados ou que carecem de voz própria, e da mitigação dos indesejáveis efeitos secundários da atividade econômica. (SEKN, 2006, p.264)

O estudo realizado pela SEKN junto a empreendimentos sociais que operam na América Latina com foco em iniciativas de mercado socialmente inclusivas exemplifica este tipo de geração de valor social. Tais empreendimentos propiciaram o aumento da renda e redução da pobreza, ainda que de forma insuficiente para mitigá-la; o acesso a bens e serviços de qualidade por meio da redução de preços, da flexibilização do crédito e da oferta local; a construção de cidadania, ou seja, a possibilidade exercer direitos e deveres; e o desenvolvimento do capital social. (SEKN, 2010)

Conclui-se que a região, o país e o contexto influenciam não apenas as características que o empreendimento social vai adotar, mas também o escopo, a escala de sua atuação e o tipo de resultado obtido. Daí a riqueza e a grande diversidade de iniciativas que se inserem neste campo, tornando-o profundamente heterogêneo e composto por soluções moldadas de acordo com o ecossistema no qual se inserem.

\subsection{Conceitos adotados neste estudo}

\subsubsection{Desenvolvimento Social}

No recorte adotado para este estudo, o conceito utilizado para desenvolvimento social baseiase nas proposições de Sen (2000, 2007), Sachs (2004), Kliksberg (1997, 2007) e nas discussões sobre desenvolvimento local. Assim, o desenvolvimento social é entendido, em uma perspectiva local, como a ampliação das capacidades (capabilities) responsáveis pela melhoria da qualidade de vida de um dado grupo de pessoas, uma dada comunidade ou um dado território. É promovido com a ação intencional de atores para a remoção de determinadas condições que causam a privação de liberdades econômicas, sociais e políticas, 
propiciando, por exemplo, acesso a programas de assistência a minorias, à educação de qualidade, a programas de proteção e promoção da saúde, a condições adequadas de moradia, à geração de renda e de emprego, associados à promoção e ao fortalecimento do capital social.

\subsubsection{Empreendimentos Sociais}

Fundamentando-se nas proposições dos diversos autores e linhas que versam sobre o tema e foram discutidos neste estudo, os empreendimentos sociais são definidos a partir das características sintetizadas por Ashoka, 2011; Fischer, 2011; Nicholls, 2006; Dees, 2001; Johnson, 2000. São iniciativas, programas ou organizações criados para promover mudanças sociais através de projetos ou ações que têm como objetivo principal a geração de valor social para um dado grupo de pessoas, uma dada comunidade ou um dado território, mobilizando diferentes e diversos atores e recursos. 


\section{METODOLOGIA}

Este estudo, de caráter exploratório e descritivo, teve o objetivo de compreender como os resultados auferidos por empreendimentos sociais no Brasil contribuem para o desenvolvimento social. A pesquisa de campo buscou verificar se as atividades dos diferentes empreendimentos sociais estudados estão intencionalmente voltadas para melhorar indicadores de desenvolvimento social e se há evidências de que estes indicadores sejam afetados por tais ações. O estudo se propôs, sobretudo, a compreender como esses empreendimentos são constituídos e operam a fim de promover (ou não) a(s) dimensão(ões) do desenvolvimento social com as quais lidam.

Os indícios de que os empreendimentos sociais contribuem ou contribuíram para a promoção do desenvolvimento social em âmbito local foram obtidos por métodos complementares de entendimento do fenômeno, inseridos em uma perspectiva qualitativa, construtivista e dedutiva. Consideraram-se os resultados das ações executadas, inseridos em uma análise de contexto que privilegia o estudo da dinâmica na relação entre os empreendimentos, as respectivas iniciativas locais apoiadas e os atores com influência neste contexto, contribuindo para que os objetivos pretendidos sejam alcançados. A análise desta dinâmica partiu do estudo da trama social na qual o empreendimento social se insere, sob a ótica das relações que se estabelecem entre os diferentes atores envolvidos, as estruturas criadas e a influência desses elementos na adoção de novas atitudes.

A trama social foi trabalhada a partir da noção de "campos" e "habitus" proposta por Bourdieu e sua utilização como ferramenta metodológica, com base nos estudos e discussões levantados por Misoczky (2003), Vilarinho (2004), Martín Criado (2008), Mayoral Blasco (2010) e Robertt (2010), entre outros.

Misoczky (2003) observa que, do ponto de vista metodológico, uma das principais implicações do uso das formulações de Bourdieu em estudos organizacionais é o rompimento com as tradições funcionalistas e estruturalistas. Bourdieu (1990) busca romper com a concepção de sujeitos como "autômatos regulados”, própria do estruturalismo, reintroduzindo 
no campo das ciências sociais a concepção de "agentes sociais", atribuindo uma intenção ativa e inventiva à prática desses agentes.

As propostas de Bourdieu também implicam no rompimento com a busca de relações causais entre elementos para a formulação de leis gerais, característica do positivismo. O foco do pesquisador aborda a interação entre subjetivismo e objetivismo de forma construcionista na apreensão do objeto (MISOCZKY, 2003). Assim, as práticas de pesquisa voltam-se para a compreensão, partindo do reconhecimento de que tanto o sujeito quanto o objeto são construções socio-históricas que precisam ser problematizadas. Como consequência, pode-se inferir que "os critérios e conceitos utilizados são construções humanas e históricas; sendo assim, não podem, por princípio, ser invariantes" (Ibid., p. 26).

Resumidamente, as ideias de Bourdieu agregam aos estudos organizacionais a possibilidade da integração, em um único modelo analítico, da experiência de agentes sociais e da análise de estruturas objetivas que tornam essa experiência possível (BOURDIEU, 1988 apud WESTERMANN, 2007).

Na concepção de Bourdieu, os campos são espaços sociais historicamente constituídos, com instituições e leis de funcionamento próprias. Um campo é uma rede de relações objetivas entre posições ocupadas por diferentes agentes. (MAYORAL BLASCO, 2010). No estudo realizado, em cada caso, delimitou-se como campo o espaço social onde se desenvolve a ação do empreendimento social em uma iniciativa voltada para a promoção do desenvolvimento em nível local. Esses campos se configuram pela presença de relações e interações entre os seguintes tipos de agentes:

- $\quad$ Empreendimento social: organização que cria e executa um projeto ou ação que visa contribuir para a promoção do desenvolvimento social.

- Iniciativa apoiada: grupo de pessoas, comunidade ou localidade participante da ação ou do projeto desenvolvido pelo empreendimento social com o objetivo de contribuir para a promoção do desenvolvimento social.

- Outros agentes: organizações, instituições e grupos que influenciam a ação e os resultados obtidos pelo empreendimento social e pela iniciativa apoiada, interagindo com estes agentes, tais como financiadores e instâncias governamentais. 
As posições ocupadas pelos agentes no campo são definidas de acordo com tipos específicos de capitais - os elementos constituintes do poder detido e mobilizado por cada agente no campo, como capital econômico, capital político, capital simbólico, dentre outras formas. O conceito de capital refere-se aos elementos que têm valor em um campo; são os elementos que permitem ao agente exercer determinado poder, influência, ou seja, existir em um campo específico. Diferentes tipos de capital são distribuídos de forma desigual no campo, e mobilizados pelos agentes na medida em que se relacionam e se enfrentam, com meios e fins diferenciados, conforme suas posições relativas no campo. (BOURDIEU, 1990; MISOCZKY, 2003; MARTÍN CRIADO, 2008; MAYORAL BLASCO, 2010).

No estudo realizado, foram identificados seis tipos de capitais detidos pelos agentes que interagem com os empreendimentos sociais e as iniciativas observadas. Buscando contemplar as particularidades presentes em tais campos, esses capitais foram definidos da seguinte forma:

- Capital intelectual: metodologia e know-how que fundamentam as ações realizadas no campo;

- Capital financeiro: recursos financeiros, de origem pública ou privada, destinados às ações realizadas no campo;

- Capital político: influência exercida por instituições e sistemas políticos cujos poderes são reconhecidos pelos agentes do campo;

- Capital humano: conjunto de capacidades que permitem às pessoas desenvolverem seus potenciais, aproveitarem oportunidades e realizarem ações conjuntas e integradas no campo;

- Capital técnico-operacional: capacidade técnica instalada associada à capacidade de execução de uma ação efetiva no campo;

- Capital operacional: capacidade de apoiar institucionalmente a execução de ações no campo.

Metodologicamente, a noção de "campo" é muito útil para a compreensão da dinâmica que caracteriza um empreendimento em dado momento histórico. O conceito de campo 
proporciona uma potente ferramenta metodológica para analisar diferentes âmbitos de relações sociais, sem reduzi-los a funções gerais ou a instrumentos de uma classe dominante:

Ao enfatizar as lutas no interior do campo como principal elemento da dinâmica e estrutura dos campos, o conceito se liga a uma metodologia relacional e histórica: a estrutura de um campo determinado é o resultado das lutas e dinâmicas anteriores e será modificada pelas posteriores. A mesma autonomia do campo somente é compreendida como resultado de um processo histórico de autonomização. (MARTÍN CRIADO, 2008, p.17).

Assim, neste estudo, o conceito de campo é empregado com o objetivo de incorporar o contexto à análise do empreendedorismo social. Outrossim, será adotado o conceito de habitus, ou conjunto de disposições presentes no campo, uma vez que elas influenciam ou determinam a ação dos agentes. Com efeito, para a filosofia da ação de Bourdieu, o ponto central é a relação - de mão dupla - entre as estruturas objetivas (dos campos sociais) e as estruturas incorporadas (do habitus) (MISOCZKY, 2003).

A proposição de habitus é ampla e complexa; é quase impossível de ser integralmente contemplada em uma só definição. O habitus é constituído pelo saber prático das leis de funcionamento dos campos, o qual é adquirido pelos agentes através da socialização prévia e/ou por aquela praticada no próprio campo, e que define uma tendência ou maneira de atuação com espaço para escolhas. Assim, o conceito de habitus está estreitamente unido ao de campo, em face da relação intensa entre as posições sociais (estrutura do campo), as disposições (habitus) e as práticas dos agentes no campo. (BOURDIEU, 1990; MISOCZKY, 2003; MAYORAL BLASCO, 2010).

Bourdieu (1990, p. 21) argumenta que o "habitus gerador" é um sistema de disposições adquiridas pela experiência, e, portanto, variáveis conforme o lugar e o momento onde residem os princípios que norteiam a ação dos agentes sociais. O habitus, uma "necessidade tornada virtude" (Ibid., p.23), produz estratégias objetivamente ajustadas à situação, mas que não são regidas pela razão, não são produto de uma aspiração consciente. Assim, o habitus determina que as condutas dos agentes não são produto de estratégias conscientes nem de determinações mecânicas. 
O habitus também pode ser entendido como um sistema de disposições duráveis e transferíveis; simultaneamente produto da prática e princípio ou matriz geradora de práticas. Ao integrar experiências passadas, funciona como uma matriz de percepções, apreciações e ações dos agentes. Embora o princípio gerador do habitus imponha regularidades inscritas em condições objetivas e estruturais, o habitus é suficientemente flexível para possibilitar improvisações reguladas, que são as possibilidades de inovação e transformações sociais. (MICELI, 2007).

Enquanto a posição dos agentes no campo é revelada pelas diferentes formas de capital que cada um detém, o habitus revela-se nas crenças e valores que norteiam suas ações e aspirações, nos aprendizados proporcionados pelo campo e nas práticas adquiridas ou desenvolvidas pelos agentes nas relações que estabelecem entre si. Torna-se conhecido pela prática e pelo discurso dos agentes que operam no campo.

Em termos metodológicos, Bourdieu propõe que a análise de um determinado campo, como o intelectual ou o artístico, envolve três momentos necessários e internamente conectados (BOURDIEU, 2007; BOURDIEU; WACQUANT, 1992 apud MISOCZKY, 2003):

(1) analisar a posição do campo na estrutura de poder ou em relação a ela;

(2) mapear as relações objetivas entre as posições ocupadas pelos agentes ou instituições que se relacionam e competem em cada campo; e

(3) analisar o habitus dos agentes, o sistema de disposições adquiridas pela internalização de determinados tipos de condições sociais e econômicas, constitutivo do princípio gerador e unificador das práticas e ideologias que caracterizam aquele grupo de agentes.

A partir dessas proposições, a análise de um objeto no âmbito dos estudos organizacionais adquire características que foram observadas na condução desta pesquisa. Elas são sintetizadas por Misoczky (2003) da seguinte forma:

- $\quad$ Focalizar em processos e em relações;

- Reconhecer que agentes são ativos e atuantes;

- Observar a ação a partir de seu caráter intencional;

- Conceber a organização como uma construção social; 
- $\quad$ Reconhecer que os esquemas de percepção e a estrutura possuem gênese social;

- $\quad$ Analisar a estruturação do campo;

- Reconhecer a possibilidade de alterações nos tipos de capital que estruturam o campo;

- Compreender como sendo permanente o processo de produção social, acumulação, transformação e reprodução;

- $\quad$ Aceitar que as estruturas podem ser reproduzidas ou transformadas.

A análise do contexto onde os empreendimentos sociais operam, com a noção de campo como ferramenta metodológica, implica em pensar este espaço social em termos de relações entre posições, a exemplo de estudo conduzido por Robertt (2010) acerca de organizações formais. Assim, o presente estudo visa identificar e descrever as diversas posições ocupadas pelos agentes no campo, determinadas pela posse de diferentes capitais e determinantes das condutas e interações no campo. A partir da construção da rede de relações entre os agentes e da identificação dos capitais que detêm no campo, buscou-se analisar as diferentes posições de modo relacional.

Do ponto de vista da coleta e análise dos dados para este estudo, os campos foram constituídos e analisados com base em três dimensões: (1) Estrutura do campo, (2) Posições ocupadas pelos agentes, e (3) Disposições e práticas do campo (habitus). Essas dimensões, empregadas inicialmente por Mayoral Blasco (2010), permitiram operacionalizar a análise do contexto no qual os empreendimentos sociais operam.

A segunda dimensão de análise deste estudo envolve os resultados das ações executadas pelos empreendimentos estudados sob a perspectiva do desenvolvimento social em âmbito local. Diversas metodologias e ferramentas têm sido empregadas para este tipo de avaliação sem que haja consenso sobre o melhor tipo a ser aplicado em diferentes situações e contextos. Alguns fatores que podem influenciar a aplicabilidade de diferentes ferramentas são, entre outros: os objetivos da avaliação, a amplitude de tempo e recursos financeiros para coleta e análise de dados, a disponibilidade de dados sistematizados e o tipo de abordagem metodológica que fundamenta a avaliação ou estudo.

Abordagens quantitativas para avaliação de impacto têm sido largamente utilizadas na análise dos resultados de programas de microcrédito, por exemplo. Como discutido por Monzoni 
(2008), essas avaliações buscam medir a magnitude das mudanças no comportamento e nas práticas dos atores envolvidos nos programas pela redução da pobreza e a promoção do empreendedorismo. Os métodos de pesquisa comumente utilizados para este tipo de mensuração implicam na utilização de grupos de controle ou, na ausência de condições para tal monitoramento, a pesquisa realizada com grupos de veteranos e com entrantes no programa. O projeto Assessing the Impactsof Microenterprise Services (AIMS), lançado pela Usaid em 1995, aplicou com sucesso esta segunda abordagem em diferentes países e realidades. (MONZONI, 2008)

Numa perspectiva qualitativa e construtivista, o presente estudo teve como ponto de partida a análise de contexto propiciada pelo conhecimento do campo e do habitus de cada caso estudado. Nessa conjuntura, os indicadores de resultados foram identificados conforme referencial metodológico aplicado nas experiências em avaliação de impacto promovidas pela Oxfam e pela Novib em alguns países onde essas instituições apoiavam projetos e organizações descritas e discutidas por Roche (2002).

Roche (2002) apresenta estudos de caso envolvendo ONGs e empreendimentos sociais de 11 países, nos quais foram aplicadas diferentes metodologias para a avaliação do impacto alcançado pelos programas e projetos operados por essas organizações investigadas. As avaliações tiveram como objetivo central identificar mudanças significativas na vida das pessoas beneficiadas pelos programas em análise. A seleção entre aquelas metodologias para a observação dos resultados obtidos pelos empreendimentos estudados nesta tese se deu pela similaridade de objetivos e pressupostos de ambos os estudos, como detalhado a seguir.

A distinção entre resultados ou efeitos e impacto de uma intervenção é de difícil aplicação na prática avaliativa. Segundo Roche (2002, p.38) o impacto pode ser avaliado "ao se analisar o grau até onde os resultados de uma intervenção conduziram a mudanças nas vidas daqueles que se pretendia beneficiar." Essa avaliação se torna ainda mais complexa ao se considerar que as intervenções sociais não podem ser isoladamente responsáveis pelos resultados ou impactos verificados numa dada situação. É necessário considerar que as mudanças são produzidas a partir da combinação das ações de um projeto ou programa com a dinâmica do contexto no qual as atividades ocorrem. Assim, a análise de resultados e de impacto deve levar em conta que a mudança ocorre sob condições particulares da situação, das pessoas envolvidas e das ações em curso, além de ser influenciada por imprevistos repentinos no 
macro e/ou no micro contexto, como crises econômicas, conflitos sociais, mudanças na infraestrutura local e perda de líderes carismáticos, por exemplo.

Conceitualmente, resultados ou efeitos de uma intervenção social podem ser entendidos como as mudanças percebidas pela população-alvo do projeto, por exemplo, a melhoria de renda ou a aquisição de um conhecimento. Num nível superior de análise, o impacto contempla as mudanças produzidas pelos resultados daquela intervenção na vida das pessoas que se pretendeu beneficiar, como a melhoria na qualidade da alimentação de uma família, em razão do aumento da renda. Roche (2002) adverte que as diferenças próprias destes níveis de mudança podem não ser evidentes na prática e não ter sentido para os membros das comunidades. Nesse contexto, o presente estudo manteve seu foco na identificação dos resultados obtidos pelos empreendimentos sociais, como previsto nos objetivos propostos.

Em linha com as proposições de Bourdieu para análise das dinâmicas sociais, Roche (2002) adverte que a avaliação de mudanças provocadas por determinado projeto ou programa deve ser situada em seu contexto mais amplo:

O desenvolvimento e a mudança nunca são o produto isolado de um processo posto em prática por agências de desenvolvimento e pelas ONGs. Mais propriamente, são o resultado de processos mais amplos, produto de muitos fatores sociais, econômicos, políticos, históricos e ambientais inclusive a luta pelo poder entre diferentes grupos de interesse. (ROCHE, 2002, p.42).

Para captar esta complexidade, a construção de indicadores para avaliação dos resultados obtidos pelos empreendimentos sociais estudados não se restringiu à aplicação de uma lista de verificação de fatores pré-determinados. Com isso, buscou-se evitar que a análise ficasse restrita ao tipo e às áreas de mudança mais visíveis aos interesses da avaliação. Buscando encontrar resultados e impactos mais amplos na vida das pessoas, esta abordagem explorou as mudanças provocadas pelo projeto sem se limitar ao seu escopo original. Os indicadores foram, então, identificados a partir dos próprios exemplos trazidos pelas pessoas, ao relatarem mudanças nas áreas ou dimensões de vida pesquisadas, permitindo a observação de mudanças não previstas pelo projeto. (ROCHE, 2002)

Os indicadores obtidos no estudo podem ser agrupados em três categorias que nortearam a análise em cada caso. Estas categorias são similares às identificadas por Roche (2002), como 
dimensões básicas de mudança, comuns entre os estudos de casos que elaborou. Neste estudo, essas categorias são definidas da seguinte forma:

- $\quad$ Riqueza material: indicadores que dizem respeito à situação socioeconômica, tais como renda, acesso a consumo e a oportunidades de trabalho.

- Bem-estar social ou capital humano: indicadores que dizem respeito à qualidade de vida, tais como acesso a programas de saúde, educação e moradia.

- Empoderamento ou capital político e social: indicadores que dizem respeito ao exercício da cidadania, à participação social e à construção do capital social, tais como acesso a benefícios sociais e criação de relações locais de confiança e cooperação.

A categorização utilizada teve fins meramente analíticos e não pressupõe que a qualidade ou a intensidade dos resultados obtidos nas iniciativas estudadas sejam aferidas a partir da maior ou da menor ocorrência de indicadores nas três categorias propostas. De fato, a maior parte dos indicadores tendeu a se concentrar em uma ou duas categorias em cada caso, explicitando especificidades dos resultados obtidos frente aos diferentes objetivos propostos e metodologias empregadas por cada empreendimento social estudado.

\subsection{Protocolo de Pesquisa}

A pesquisa realizada aborda um fenômeno contemporâneo e complexo, inserido em seu contexto, buscando compreender suas características, natureza e formas de manifestação. A partir dos resultados obtidos, buscou-se propiciar uma nova compreensão do fenômeno empreendedorismo social, ao colocá-lo sob a ótica do desenvolvimento social. O estudo se caracteriza, portanto, como exploratório, de acordo com Selltiz et al (1975). Procurando obter uma compreensão profunda deste fenômeno e sua dinâmica, empregou-se o estudo de caso como método de pesquisa, ou seja, uma estratégia de investigação cujo foco é a compreensão da dinâmica em condições particulares ou únicas (EISENHARDT, 1989). Ou, ainda, como propõe Yin (2010), uma investigação empírica que aborda um fenômeno contemporâneo em profundidade e em seu contexto real.

A unidade de análise deste estudo é o empreendimento social, abordada em um projeto de caso múltiplo, no qual, conforme tipologia proposta por Yin (2010), diferentes casos são estudados em seus contextos particulares. 
Dentro do universo de empreendimentos sociais, o recorte da pesquisa abrangeu aqueles cujas atividades envolvem grupos, comunidades ou territórios com altos índices de vulnerabilidade social, situados em áreas urbanas da Grande São Paulo. Seguindo o procedimento de replicação proposto por Yin (2010) buscou-se identificar casos que pudessem predizer resultados similares (replicação literal) e, como sugere Eisenhardt (1989), procedeu-se a uma amostragem teórica, onde os casos foram escolhidos por razões teóricas, não estatísticas. A seleção de casos foi intencional, com foco naqueles que maximizassem a qualidade e o valor das informações e dados obtidos frente aos objetivos deste estudo, conforme os seguintes critérios teóricos:

1) Origem da iniciativa: identificação de oportunidades para promover mudanças sociais.

2) Motivação: criar soluções para lidar com a complexidade que caracteriza o cenário de privação de liberdades de um grupo de pessoas, uma comunidade ou uma localidade.

3) Finalidade ou intento estratégico: contribuir para a promoção do desenvolvimento social através de ações ou atividades orientadas para um ou mais de um dos seguintes objetivos: proteção e fortalecimento do capital social, geração de renda e de emprego, acesso a saúde, a educação, a condições adequadas de moradia e à assistência a minorias.

4) Formas de ação: mobilização de atores pertencentes ao grupo, comunidade ou território na concepção, implantação ou execução das atividades; criação de mecanismos para a ampliação de capacidades destes atores; geração de resultados observáveis no sentido do desenvolvimento social.

Um mapeamento de empreendimentos sociais que operam na Grande São Paulo e atendem aos critérios de seleção de casos foi realizado entre outubro de 2011 e janeiro de 2012. Compreendeu a realização de entrevistas com especialistas e gestores com larga experiência no fomento ao empreendedorismo social, ligados às seguintes organizações: ASHOKA Empreendedores Sociais, Fundação AVINA, Artemísia Negócios Sociais e Potencia Ventures. Foram identificados 31 empreendimentos, para os quais se procedeu ao levantamento de dados secundários disponíveis em sites, relatórios e matérias jornalísticas de acesso público, sobretudo na internet. 
Ao mapeamento de empreendimentos sociais, seguiu-se a análise do enquadramento dos casos potenciais conforme os critérios de seleção definidos para este estudo. Uma vez constatada a aprovação da maior parte dos casos em face dos critérios de seleção, procedeu-se uma escolha aleatória dos empreendimentos combinada com a busca de diversidade no tipo de iniciativas a serem estudadas, em termos de formas de ação e localização, limitada à região Metropolitana da Grande São Paulo. Em contatos iniciais, verificou-se o interesse e a disponibilidade de acesso aos empreendedores para participação na pesquisa. Foram, então, definidos os três casos participantes deste estudo: Aliança Empreendedora e sua iniciativa junto à Cooperativa ViraLata; Rede Interação e sua iniciativa na Comunidade dos Portais; e Fundo Zona Leste Sustentável em sua atuação nos bairros de São Miguel, Ermelino Matarazzo e Itaim Paulista.

\subsubsection{Coleta de Dados}

A coleta de dados ocorreu entre os meses de março e junho de 2012. Para sua realização, foram empregadas técnicas que visaram contemplar os casos sob a perspectiva dos espaços sociais nos quais se inserem, e que se configuram como campos, a exemplo de trabalhos realizados por Vilarinho (2004) e Robertt (2010). Buscava-se captar o contexto no qual se observam os resultados das ações dos empreendimentos sociais, além dos indicadores que apontam quais são estes resultados ou impactos, como proposto por Roche (2002). Tal opção está alinhada aos princípios propostos por Yin (2001) para a coleta de dados no estudo de caso: a utilização de várias fontes de evidência, uma reunião formal dessas informações e o seu posterior encadeamento.

Inicialmente, foram coletados e analisados dados secundários dos empreendimentos sociais e respectivas iniciativas apoiadas, visando conhecer seus históricos, frentes de atuação e resultados obtidos. Além de matérias jornalísticas, esses dados emanaram de fontes institucionais, como sites, folders, relatórios e publicações, disponibilizados pelos empreendimentos sociais ou acessados via internet.

Visitas iniciais foram realizadas às iniciativas participantes do estudo, com o intuito de efetuar observações, identificar informantes, definir a logística e a agenda de coleta de dados. Em visitas posteriores aos mesmos locais e às sedes dos empreendimentos sociais, foram 
realizadas entrevistas com 4 empreendedores sociais, 4 gestores ou técnicos dos empreendimentos diretamente envolvidos com as três unidades de análise, além de amostras das pessoas beneficiadas pelas iniciativas, compostas por 3 lideranças locais e 16 pessoas identificadas aleatoriamente ou por indicação dos empreendimentos sociais. Totalizaram 28 entrevistas ${ }^{8}$, as quais foram gravadas e transcritas para posterior análise de conteúdo.

Roteiros semi-estruturados foram empregados nesse procedimento. A construção destes roteiros buscou manter homogeneidade das perguntas aplicadas, em linha com os objetivos da pesquisa e, ao mesmo tempo, permitindo adaptações, com base nas diversas naturezas dos informantes e no tipo de informação proporcionada por cada um deles. Assim, foram empregados quatro tipos de roteiros: um aplicado junto aos fundadores dos empreendimentos sociais, outro direcionado para o corpo de técnicos destes empreendimentos, um terceiro voltado para participantes da iniciativa apoiada pelo empreendimento e um último roteiro junto aos empreendedores ou líderes locais dessas iniciativas ${ }^{9}$.

\subsubsection{Análise dos dados}

A análise dos dados coletados para este estudo fundamentou-se em uma abordagem qualitativa. Segundo Langley (1999), uma das principais razões para o uso desta abordagem é a possibilidade de incorporar o contexto, como postulam Pettigrew e Yin. Aquela autora privilegia o uso de abordagens qualitativas no processamento de dados como um meio para construir teorias que não percam a riqueza, o dinamismo e a complexidade desses dados, além de organizá-los de forma inteligível e útil.

Os dados coletados neste estudo foram analisados por meio de uma estratégia narrativa, segundo tipologia proposta por Langley (1999). Alinhada à perspectiva construtivista de Pettigrew (1985) para os estudos organizacionais, essa estratégia privilegia a variedade e a riqueza dos eventos descritos e os links entre eles, visando gerar um grau de autenticidade que não pode ser obtido com grandes amostras. Além de implicar na organização sistemática dos dados, tal estratégia prioriza os significados dos eventos para os indivíduos, ou seja, o modo como foram vivenciados.

\footnotetext{
${ }^{8}$ Um dos empreendedores sociais concedeu 2 entrevistas.

${ }^{9}$ Os roteiros de entrevistas são apresentados no Apêndice 1.
} 
Objetivando chegar a contribuições teóricas, a análise dos dados não se limitou a uma narrativa exclusivamente descritiva. Partindo da combinação das informações obtidas mediante o uso das diversas técnicas de coleta de dados, foram geradas categorias e codificações, permitindo a identificação de padrões comuns a cada caso e ao conjunto de casos, os quais funcionaram como dispositivos para a interpretação teórica, como propõem Langley (1999) e Eisenhardt (1989).

A categorização dos dados foi feita por meio da técnica de análise de conteúdo, com a aplicação de procedimentos sistemáticos e objetivos de descrição do conteúdo das mensagens (dados coletados), para chegar a indicadores (quantitativos ou não) que permitissem a inferência de conhecimentos relativos às condições de produção e recepção das mensagens (Bardin, 1977). Neste estudo, optou-se por uma abordagem qualitativa para a análise de conteúdo, dado o caráter exploratório na busca por novas conexões e proposições teóricas sobre o fenômeno, a partir dos relatos dos informantes e dos dados secundários utilizados. $\mathrm{O}$ emprego da análise de conteúdo teve por objetivo conferir à análise dos dados maior confiabilidade e validade do que se costuma obter por meio de leituras e avaliações feitas de forma livre.

A análise de conteúdo se dá num processo com diferentes etapas, cujas terminologias variam entre autores, guardando semelhanças entre si. Bardin propõe as seguintes fases: 1) préanálise, 2) exploração do material e 3) tratamento dos resultados, inferência e interpretação. (BARDIN, 1977; MOZZATO; GRZYBOVSKI, 2011)

Na pré-análise dos dados, todo o material foi organizado, tendo como referência os objetivos da pesquisa e o referencial teórico que a fundamenta. A exploração do material fundamentouse na codificação e categorização, ou seja, no processo de classificação do material em categorias estruturadas conforme os padrões encontrados em cada caso e, posteriormente, no conjunto dos casos. Essas categorias são: campo: agentes e capitais; características do habitus; indicadores de riqueza material; indicadores de bem-estar social ou capital humano; indicadores de empoderamento ou capital político e social. 
Por meio da descrição dos casos, foi feito o tratamento dos resultados, culminando com as interpretações inferenciais baseadas na intuição, na análise reflexiva e crítica, como propõe Bardin (1977).

Os capítulos a seguir apresentam os resultados obtidos por meio do emprego das técnicas de coleta e de análise de dados descritos. São apresentados e discutidos os três estudos de casos, seguindo-se um capítulo de análise conjunta dos casos e, posteriormente, a discussão de conclusões e recomendações que este estudo encerra. 


\section{APRESENTAÇÃO DOS RESULTADOS E ANÁLISES}

\subsection{Considerações sobre o empreendedorismo social no contexto brasileiro}

Esta tese principiou com um estudo exploratório realizado junto a quatro especialistas na prática do empreendedorismo social no Brasil, com o objetivo de identificar potenciais casos de estudo, compreender quais características eles assumem em nosso contexto e identificar tendências para o setor. Deste mapeamento inicial, resultaram importantes reflexões, as quais são apresentadas a seguir.

Como já discutido na fundamentação teórica deste estudo, os empreendimentos sociais que operam no Brasil tendem a ter resultados localizados e muito raramente com impacto em larga escala. A especialista Vivianne Naigeborin observa que Estados Unidos e Europa apresentam condições mais propícias para criar iniciativas de amplo impacto, uma vez que a cultura desses países valoriza soluções de grande abrangência, tem menor aversão a riscos e, apesar da crise econômica global, ainda oferece um cenário mais favorável à captação de recursos, se comparado ao contexto latino-americano. Na Índia, a pobreza disseminada e a carência de equipamentos públicos sociais mínimos em saúde e educação contribuem para impulsionar o surgimento de empreendimentos de grande escala. Na África, soma-se a estas características a abundância de recursos financeiros e humanos oriundos de outros países, investidos em empreendimentos sociais. Além disso, como ressalta uma das especialistas entrevistadas, Maure Pessanha, a pobreza característica na Índia e na África difere do tipo de pobreza manifesto no Brasil, primordialmente urbano. Por essa razão, modelos de empreendimentos sociais bem-sucedidos na Índia e em países do continente africano são de difícil transposição para o contexto brasileiro, embora algumas metodologias desenvolvidas nesses empreendimentos tenham boa replicabilidade em determinadas circunstâncias mais universais, como o acesso a moradia.

O perfil de empreendedor que predomina na América Latina também parece estar associado à dificuldade presente na geração de impactos de amplo espectro. A partir de seus mais de 10 anos de experiência junto a empreendedores sociais, Naigeborin observa que essas pessoas têm como característica marcante o fato de serem inovadoras e, por isso, mais propensas a 
desenvolver sucessivos processos criativos, em vez de focar-se na consolidação e expansão de suas iniciativas. Ao mesmo tempo, há empreendedores que se contentam com resultados mais modestos na abrangência de sua ação direta, alegando que seu empreendimento pode ampliar impacto influenciando e inspirando outros, sem necessariamente expandir-se. Naigeborin ainda observa que os empreendedores indianos, americanos e europeus costumam ser mais pragmáticos, enquanto os latino-americanos tendem a ser mais ideológicos.

Outra premissa importante em empreendimentos que precisam crescer é a necessidade de implementar processos sistematizados e profissionalizar a gestão. Essa é uma dificuldade enfrentada por muitos empreendimentos sociais que operam na América Latina e ainda são geridos de forma amadorística, com características semelhantes à gestão de empresas familiares, como: a centralização de atribuições, das responsabilidades e do processo decisório; a informalidade administrativa e; a carência de planejamento.

No macrocontexto, Naigeborin observa que muitas iniciativas desenvolvidas pelos empreendedores sociais na América Latina são criadas sem incorporar as lógicas próprias das políticas públicas e, por isso, têm sua escala de atuação reduzida. Por outro lado, como observa a especialista Tiana Lins, o contexto onde os empreendimentos sociais operam está passando por uma grande mudança. O país vem assegurando questões básicas, embora outras ainda sejam muito carentes e é neste campo que se percebem conjunturas para que os empreendimentos gerem maior impacto. É quando surgem oportunidades para que os empreendedores sociais criem iniciativas de desenvolvimento local que fomentem a inovação e o diálogo com políticas públicas, embora as experiências neste sentido sejam ainda pouco frequentes.

A criação de empreendimentos que de fato aproveitem oportunidades para desenvolver e aplicar inovações no campo social tem sido crescentemente dificultada pela carência de recursos financeiros para investimento. A saída de financiadores internacionais desde a década de 1990 vem interferindo na forma como as soluções são criadas e implementadas. Lins avalia que, neste contexto, os jovens e os antigos empreendedores encontram-se sem resposta para duas questões centrais: como pensar o desenvolvimento e como conseguir promovê-lo? Para a entrevistada, de um lado, muitos modelos mais antigos de empreendedorismo ainda são válidos, embora não encontrem fonte de recursos que assegure sua sobrevivência. De outro lado, não há recursos para experimentos que impliquem na 
modelagem e na implementação de novas soluções, cujos resultados concretos são visíveis apenas no longo prazo. A fim de que novas iniciativas sejam desenvolvidas com sucesso, o financiamento deve prever certa flexibilidade na aplicação dos recursos, para que sejam feitos os ajustes demandados na fase de modelagem. Também deve prever o tempo necessário para que a iniciativa seja realizada com o legítimo envolvimento da comunidade.

As especialistas entrevistadas sinalizam que o empreendedorismo social "clássico", ancorado no Terceiro Setor e em formas organizativas mais tradicionais, deve passar por mudanças. A emergência dos negócios sociais como alternativa capitalista para promoção do desenvolvimento local é uma tendência que tem se consolidado em muitos países e começa a ganhar força no Brasil.

Em nosso país, já se observam casos de organizações sem fins lucrativos mais tradicionais, criadas no bojo dos movimentos sociais das décadas de 1970 e 1980, legitimadas e consolidadas em sua atuação, que buscam modelos de negócios sociais para a continuidade de suas atividades, como observa Pessanha. Essas organizações mantêm finalidades sociais em sua missão, mas passam a incorporar modelos de mercado em determinados projetos ou programas, buscando formas mais sustentáveis de financiamento e visando também ampliar e diferenciar sua atuação. Entretanto, de acordo com Pessanha, muitas vezes esse tipo mais moderno de empreendedorismo social esbarra em questões intra-geracionais. Muitos jovens que concluem o nível universitário e ingressam no mundo do empreendedorismo social atribuem muito sentido à utilização de mecanismos de mercado como uma forma legítima de promoção do desenvolvimento social ou ambiental. Contudo, as gerações precedentes, de fundadores e seus sucessores, ainda apresentam grande resistência para mudar o paradigma do valor econômico, tido como menos importante ou até contraditório frente ao valor social.

As entrevistadas concordam que a nova geração tem formação mais híbrida, assimila mais facilmente a mentalidade negocial e tem menos aversão ao setor corporativo. Mas também é composta por pessoas que buscam associar o idealismo à estabilidade financeira e plano de carreira. São empreendedores com facilidade para trabalhar em conjunto e compartilhar ideias. É nesse contexto que os negócios sociais ganham força. 
Pessanha observa ainda que essa mudança de paradigmas também se faz presente nas iniciativas que surgem nas comunidades periféricas. O "empreendedorismo de necessidade", marcado pela busca de soluções de caráter mais assistencialista para problemas sociais crônicos, começa a mudar para o "empreendedorismo de oportunidade", onde se buscam soluções mais sustentáveis e de maior impacto social.

Por fim, para as especialistas entrevistadas, seja qual for o tipo de empreendimento social, há uma tendência de que ele se concretize em organizações bastante enxutas, capazes de articular outras organizações para trazer inovação. O crescente uso da tecnologia, da inovação e do trabalho cooperativo também são tendências observadas em empreendimentos que se destacam no Brasil, assim como em outras partes do mundo, e devem impactar a forma como estas organizações operam e geram valor social.

\subsection{Contexto Sócio-Econômico}

Os casos pesquisados neste estudo estão localizados em dois municípios da Grande São Paulo: a capital do estado e o município de Osasco. Dados que caracterizam o contexto socioeconômico da região e dos dois municípios em particular são apresentados neste capítulo. Destaque é dado para os indicadores que representam condições mensuráveis de desenvolvimento dentre as liberdades substantivas elencadas por Sen (2000) - as facilidades econômicas e as oportunidades sociais.

\subsubsection{Dados Gerais}

A Região Metropolitana de São Paulo (RMSP), também conhecida como Grande São Paulo, é constituída por 39 municípios, 38 dos quais se agrupam em torno da cidade de São Paulo, a capital do Estado, e são direta ou indiretamente polarizados por ela. A RMSP, com uma área de $7.947 \mathrm{~km}^{2}$, representa 0,09\% do território brasileiro e 3,2\% do Estado de São Paulo (IBGE, 2011a). O município de São Paulo é o maior da região, ocupando $1.523 \mathrm{~km}^{2}$, enquanto Osasco, com 64km², é um dos menores (IBGE, 2012). 
São Paulo é a sexta maior cidade do planeta e sua região metropolitana, com uma população estimada em 19.822.572 habitantes (em 2011), é a terceira maior aglomeração urbana do mundo e a maior do continente. A RMSP concentra $10,3 \%$ da população do país e $48,05 \%$ da população estadual. A cidade de São Paulo, com 11.316.149 habitantes, é a maior da região, e Osasco, com 667.826, a quinta (IBGE, 2011a).

Em 2009, o PIB da RMSP foi de R\$ 613,06 bilhões, representando 19\% do PIB nacional e $56,5 \%$ do PIB paulista. São Paulo teve o maior PIB da região, com $\mathrm{R} \$ 389,3$ bilhões $(63,5 \%$ do PIB da região), e Osasco, com $\mathrm{R} \$ 31,6$ bilhões (5\% do PIB da região), o terceiro (IBGE, 2011b).

Numa perspectiva histórica, entre 1999 e 2009, o PIB da RMSP, que em 1999 era de R\$ 224,4 bilhões, cresceu 173\%. O município de São Paulo, PIB de R \$ 150,9 bilhões em 1999, experimentou um crescimento de $139 \%$. Osasco teve um acréscimo de $300 \%$ no PIB, que em 1999 não chegava aos R \$ 8 bilhões, figurando como o quarto município em volume de PIB na região (Fundação Seade, 2012a).

Em 2009, o PIB per capita da região foi de $\mathrm{R} \$ 31$ mil, valor $40 \%$ superior ao PIB per capita do Estado de São Paulo, que foi de R\$25,2 mil, e 83\% acima do PIB per capita do Brasil, que foi de $\mathrm{R} \$ 16,9$ mil no mesmo período. Osasco, com $\mathrm{R} \$ 44$ mil, é o município com o quarto maior PIB per capita da região. Por outro lado, o PIB per capita de São Paulo, de R\$ 35 mil, fica na sexta posição quando comparado aos outros municípios da área. Em ambos os casos, o PIB per capita foi acima do PIB nacional e estadual (IBGE, 2011b).

Embora a RMSP apresente PIB per capita superior ao PIB per capita nacional e estadual, a distribuição da renda é desigual entre os municípios que a conformam, quando analisados individualmente. Assim, 19 dos 39 municípios da região possuem PIB per capita inferior à média nacional.

Na década de 1999 a 2009, o PIB per capita da RMSP (R\$ 12,6 mil em 1999) experimentou um incremento de 146\%. Os municípios de São Paulo (R\$ 14,7 mil em 1999) e de Osasco (R\$ 11,6 mil em 1999) tiveram crescimento de $139 \%$ e $278 \%$ respectivamente (Fundação Seade, 2012a) 
A RMSP detém a liderança econômica no país. Nos últimos anos, o setor de serviços vem se consolidando como o mais relevante na economia da região. Em 2009, este setor representou $75,4 \%$ do valor adicionado, experimentando um incremento de 5,5\% desde 1999. Nos municípios de São Paulo e Osasco, a participação do setor de serviços foi $79 \%$ no primeiro (incremento de $6,5 \%$ em relação a 1999) e até $90 \%$ no segundo (incremento de $7,9 \%$ em relação a 1999) (Fundação Seade, 2012a).

Em 2009, o setor industrial da RMSP representou $24,6 \%$ do total de valor adicionado. Ao contrário do setor de serviços, ele tem experimentado queda significativa (13\%) na última década. Nesse mesmo ano, no município de São Paulo, o setor industrial representou 20,7\%, com queda de $19 \%$ em relação a 1999. Em Osasco, em 2009, o setor industrial representou 10,4\% do valor adicionado em 1999, com queda de 39\% desde 1999 (Fundação Seade, 2012a).

O setor de serviços também é o principal empregador da RMSP, respondendo, em 2010, por $58,3 \%$ dos empregos. O comércio respondeu por $18,2 \%$, a indústria por $18 \%$ e a construção civil por 5,3\%. Os dados de emprego para São Paulo, em 2010, foram de: 63,8\% em serviços, 17,9\% no comércio, $12,6 \%$ na indústria e 5,6\% na construção civil. Já para Osasco, os empregos encontravam-se 52,2\% em serviços, $25 \%$ no comércio, $19,4 \%$ na indústria e 3,4\% na construção civil (Fundação Seade, 2012a).

A Pesquisa de Emprego e Desemprego (PED), realizada pela Fundação Seade em convênio com o Departamento Intersindical de Estatística e Estudos Socioeconômicos (Dieese), revela que o rendimento médio real das pessoas ocupadas da RMSP foi de $\mathrm{R} \$ 1.573$ no mês de março de 2012, com incremento de 0,1\% em relação a março do ano anterior (Fundação Seade, 2012b). Por outro lado, os resultados gerais da amostra do Censo 2010, publicados pelo IBGE em 2012, apontam que o rendimento nominal médio em São Paulo foi de R \$2.386,62 e, em Osasco, de R \$1.609,82 (IBGE, 2011c).

Tabela 1 - Dados Gerais

\begin{tabular}{|c|c|c|c|}
\hline Variável & RMSP & São Paulo & Osasco \\
\hline Área da unidade territorial & $7.947 \mathrm{~km}^{2}$ & $1.523 \mathrm{~km}^{2}$ & $64 \mathrm{~km}^{2}$ \\
\hline
\end{tabular}




\begin{tabular}{|c|c|c|c|}
\hline Variável & RMSP & São Paulo & Osasco \\
\hline População (2011) & $\begin{array}{r}19.822 .572 \\
\text { habitantes }\end{array}$ & $\begin{array}{r}11.316 .149 \\
\text { habitantes } \\
\end{array}$ & $\begin{array}{r}667.826 \\
\text { habitantes }\end{array}$ \\
\hline Produto Interno Bruto (2009) & $\mathrm{R} \$ 613,06$ bilhões & $\mathrm{R} \$ 389,3$ bilhões & $\mathrm{R} \$ 31,6$ bilhões \\
\hline Produto Interno Bruto per capita (2009) & $\mathrm{R} \$ 31 \mathrm{mil}$ & $\mathrm{R} \$ 35 \mathrm{mil}$ & $\mathrm{R} \$ 44 \mathrm{mil}$ \\
\hline $\begin{array}{l}\text { Percentual valor adicionado setor serviços } \\
\text { (2009) }\end{array}$ & $75,4 \%$ & $79 \%$ & $90 \%$ \\
\hline $\begin{array}{l}\text { Percentual valor adicionado setor industrial } \\
\text { (2009) }\end{array}$ & $24,6 \%$ & $20,7 \%$, & $10,4 \%$ \\
\hline $\begin{array}{l}\text { Percentual pessoas empregadas no setor } \\
\text { serviços }(2010)\end{array}$ & $58,3 \%$ & $63,8 \%$ & $52,2 \% \%$ \\
\hline Rendimento médio real dos ocupados (2011) & $\mathrm{R} \$ 1.573$ & $\begin{array}{r}\mathrm{R} \$ 2.386,62 \text { (ano } \\
2010)\end{array}$ & $\begin{array}{r}\mathrm{R} \$ 1.609,82 \text { (ano } \\
2010)\end{array}$ \\
\hline
\end{tabular}

\subsubsection{Facilidades Econômicas}

De acordo com os resultados gerais da amostra do Censo 2010, 91,7\% da população economicamente ativa da RMSP estava ocupada. Do total de pessoas empregadas, 80,4\% tinham carteira assinada e 19,6\% trabalhavam sem carteira assinada. Em São Paulo, 92,5\% da população economicamente ativa estavam ocupados e $80,4 \%$ dos empregados tinham carteira assinada. Em Osasco, a ocupação foi de $91,7 \%$, sendo $82,4 \%$ o percentual de pessoas empregadas com carteira assinada (IBGE, 2011c).

Durante a década de 2000, houve pequeno aumento no percentual de pessoas vivendo em domicílios próprios e quitados. No período, esse percentual passou de $70 \%$ para $70,6 \%$ na RMSP. Em São Paulo, o percentual passou de 69,4\% para 70,2\% e em Osasco, de 66,5\% para 67,3\% (IBGE, 2011d). O aumento no percentual de pessoas que vivem em terrenos próprios e quitados pode sinalizar avanços no poder aquisitivo da população. É possível inferir que este aumento de "intitulamento" econômico é resultante do aumento de riqueza e de renda na região.

Em 2009, os 20\% mais ricos da RMSP concentravam 56,73\% da renda, $0,46 \%$ a mais do que em 2003, quando concentravam 56,47\%. Já os $20 \%$ mais pobres, que em 2003 se apropriavam de 4,10\% de renda, tiveram um impacto de 7,5\%, passando a se apropriar de 4,41\% em 2009. No município de São Paulo, a concentração da renda nas mãos dos mais ricos é maior. Em 2009, os $20 \%$ mais ricos passaram a concentrar 58,34\% da renda, $0,93 \%$ a mais do que em 2003, quando concentravam 57,80\%. Por outro lado, os $20 \%$ mais pobres, que em 2003 se 
apropriavam de $3,94 \%$ de renda, incrementaram essa percentagem $1,67 \%$, passando a se apropriar de 4,01\% em 2009.

O índice de Gini, que mensura desigualdade na distribuição da renda passou de 0,510 em 2003 para 0,509 em 2009 na RMSP, uma variação negativa de 0,19\%, o que indica melhora na distribuição de renda. A variação na cidade de São Paulo foi similar (-0,15\%), passando o índice de Gini de 0,526 em 2003 para 0,525 em 2009 (Câmara Municipal de São Paulo, $2012)^{10}$. Na cidade de Osasco, segundo dados do IBGE, em 2003, o índice de Gini foi de 0,39 (IBGE, 2012).

Segundo o Censo 2010, 20,4\% da população da RMSP vivia com meio salário mínimo por mês (R $\$ 255$ ). 18,7\% da população de São Paulo e 20,5\% da população de Osasco viviam nessa situação (IBGE, 2011d). É importante destacar que esses dados dizem respeito ao universo de indivíduos morando em domicílios particulares permanentes, o que exclui a grande população que vive em assentamentos precários ou nas ruas da RMSP, sobretudo nas grandes cidades, e que sobrevive com mínimas possibilidades de utilizar recursos econômicos para consumo, produção ou troca.

O Relatório de Desenvolvimento Humano 2011, elaborado pelo Programa das Nações Unidas para o Desenvolvimento (PNUD), apresentou os valores e classificações do Índice de Desenvolvimento Humano (IDH), medida que avalia o progresso em longo prazo em três dimensões básicas do desenvolvimento humano: "uma vida longa e saudável, o acesso à educação e um padrão decente de vida" (PNUD, 2011). Segundo dados desse relatório, o IDH do conjunto do Brasil avançou de 0,715 em 2010 para 0,718 em 2011, o que significou a subida de uma posição no ranking mundial naquele ano. O País passou da $85^{\mathrm{a}}$ para a $84^{\mathrm{a}}$ posição, e permanece no grupo dos países de alto desenvolvimento humano.

Os dados mais atualizados do IDH para os municípios brasileiros (IDH-M) são do ano de $2000^{11}$. Segundo aquele relatório, o IDH da RMSP foi de 0,828, de São Paulo, 0,841 ( $3^{\mathrm{a}}$

\footnotetext{
${ }^{10}$ Devido ao critério de divisão de amostras, o estudo da Câmara Municipal de São Paulo alerta que a RMSP e a cidade de São Paulo só contêm a área urbana. Temos que considerar que nesta região, a população rural é pequena em relação à população urbana. O estudo não apresenta dados para a cidade de Osasco.

${ }^{11}$ De acordo com o PNUD: "até a publicação do Atlas 2013, as informações de IDH-M disponíveis para referência e uso são relativas ao Atlas de Desenvolvimento Humano 2003, com base nos dados do Censo de
} 
posição na região) e de Osasco, 0,818 ( $8^{\text {a }}$ posição na região) (PNUD, 2000). Nos três casos, o IDH é considerado elevado e supera o índice nacional.

Tabela 2 - Facilidades Econômicas

\begin{tabular}{|c|c|c|c|}
\hline Variável & RMSP & São Paulo & Osasco \\
\hline Percentual da população ocupada (2010) & $91,7 \%$ & $92,5 \%$ & $91,7 \%$ \\
\hline $\begin{array}{l}\text { Percentual da população ocupada com carteira } \\
\text { assinada (2010) }\end{array}$ & $80,4 \%$ & $80,4 \%$ & $82,4 \%$ \\
\hline $\begin{array}{l}\text { Percentual da população ocupada sem carteira } \\
\text { assinada (2010) }\end{array}$ & $19,6 \%$ & $19,6 \%$ & $17,6 \%$ \\
\hline $\begin{array}{l}\text { Percentual de pessoas em domicílios e terrenos } \\
\text { próprios e quitados (2010) }\end{array}$ & $75,4 \%$ & $79 \%$ & $90 \%$ \\
\hline $\begin{array}{l}\text { Percentual da renda apropriada pelos } 20 \% \text { mais ricos } \\
\text { da população (2009) }\end{array}$ & $56,73 \%$ & $58,34 \%$ & Não disponível \\
\hline $\begin{array}{l}\text { Percentual da renda apropriada pelos } 20 \% \text { mais } \\
\text { pobres da população (2009) }\end{array}$ & $4,41 \%$ & $4,01 \%$ & Não disponível \\
\hline Índice de Gini (2009) & 0,509 & 0,525 & $0,39(\mathrm{em} \mathrm{2003)}$ \\
\hline $\begin{array}{l}\text { Percentual de pessoas com renda per capita abaixo } \\
\text { de } \mathrm{R} \$ 255(2010)\end{array}$ & $20,4 \%$ & $18,7 \%$ & $20,5 \%$ \\
\hline Índice de Desenvolvimento Humano (2000) & 0,828 & 0,841 & 0,818 \\
\hline
\end{tabular}

\subsubsection{Oportunidades Sociais}

Do ponto de vista da ampliação das liberdades substantivas, o analfabetismo é um dos problemas centrais na área educacional. Os dados empíricos informam que o analfabetismo experimentou um processo de redução na década de 2000.

O percentual de pessoas com 10 anos ou mais analfabetas na RMSP caiu 32,7\% no período, passando de 5,2\% para 3,5\%. Osasco experimentou uma queda maior, de 35,9\%, passando de $5,3 \%$ para 3,4\% de analfabetismo das pessoas de 10 anos ou mais. A queda em São Paulo foi de 32,6\%, passando de 4,6\% para 3,1\% de analfabetismo (IBGE, 2011d).Os dados gerais da amostra do Censo 2010 revelam que 13\% da população da RMSP, 6,5\% de São Paulo e 7,2\% de Osasco nunca frequentaram creches ou escolas (IBGE, 2011c).

No campo da saúde, a década de 2000 também apresentou avanços na RMSP. A mortalidade na infância (até os cinco anos de idade) caiu 29,7\%, passando de 19,35 em 2000 para 13,61

2000.” Disponível em: <http://www.pnud.org.br/IDH/Atlas2013.aspx?indiceAccordion=1\&li=li_Atlas2013>. Acesso em:03 outubro 2012. 
por mil nascidos vivos em 2010. Os dados referentes ao município de São Paulo indicam maior redução na mortalidade que a média da região nos dois períodos, passando de 18,15 para 13,16 por mil nascidos (queda de 27,5\%). A mortalidade na infância é maior em Osasco: 21,5 em 2000 e 14,20 em 2010 por mil nascidos, mas o município experimentou a maior queda no período, 34,2\%. A esperança de vida em 2009 foi de 75,03 anos na RMSP, 75,91 anos em São Paulo e 71,35 anos em Osasco (Fundação SEADE 2012b).

De acordo com dados da Pesquisa de Assistência Médico-Sanitária do IBGE, o número de estabelecimentos de saúde cresceu 35,6\% na RMSP entre 2005 e 2009, chegando a 4.831 estabelecimentos. 44,5\% estavam localizados na cidade de São Paulo, chegando a 2.541 estabelecimentos e 24,6\% na cidade de Osasco, chegando a 142 estabelecimentos em 2009. Dentre os estabelecimentos que operavam em 2009 na RMSP, 1.344 eram públicos e 3.487 privados. Em São Paulo, 540 eram públicos e 2.001 privados e em Osasco, 47 eram públicos e 45 privados (IBGE, 2009).

As condições de moradia, que exercem forte influência nas condições de saúde e qualidade de vida, apresentaram bons resultados na década de 2000 na RMSP, de acordo com o Censo 2010. O percentual de domicílios com água encanada na RMSP passou de 96,6\% em 2000 para 97,7\% em 2010. Esse percentual é maior para os municípios de São Paulo e Osasco, que também vivenciaram aumento de 98,6\% em 2000 para 99,1\% em 2010, em ambos os casos.A coleta de lixo na RMSP também apresentou boa cobertura, passando de 98,5\% para 99,6\% dos domicílios. Em São Paulo, foi de 99,2\% para 99,8\% e em Osasco, de 98,8\% para 99,3\% (IBGE, 2011d).

Quanto à situação de esgotamento sanitário, no ano 2000, 80,8\% dos domicílios da RMSP eram atendidos pela rede geral, mas 19,2\% adotavam formas pouco salubres como "fossa rudimentar, vala, rio, lago ou mar e/ou outro escoadouro" ou não tinham banheiro nem sanitário. Em dados de 2010, o percentual de domicílios atendidos pela rede geral na RMSP aumentou para 87\%. Em São Paulo, o uso da rede geral experimentou incremento considerável entre 2000 e 2010, passando de 87,2\% para 97\%. O percentual em Osasco aumentou de 70,7\% em 2000 para 84\% em 2010.

Segundo dados do Censo 2010, $12 \%$ das pessoas residentes em Osasco e 11,4\% dos moradores de São Paulo viviam em domicílios localizados em aglomerados subnormais, 
chamados popularmente de favelas. Nestes municípios, $0,04 \%$ e $0,03 \%$ dos domicílios, respectivamente, apresentavam condições inadequadas de moradia (IBGE, 2011e).

Tabela 3 - Oportunidades Sociais

\begin{tabular}{|c|c|c|c|}
\hline Variável & RMSP & São Paulo & Osasco \\
\hline $\begin{array}{l}\text { Percentual de pessoas de } 10 \text { anos ou mais } \\
\text { analfabetas (2010) }\end{array}$ & $3,5 \%$ & $3,1 \%$ & $3,4 \%$ \\
\hline $\begin{array}{l}\text { Percentual de pessoas que nunca frequentaram } \\
\text { creche ou escola (2010) }\end{array}$ & $13 \%$ & $6,5 \%$ & $7,2 \%$ \\
\hline Mortalidade até cinco anos de idade (2010) & $\begin{array}{r}13,61 \text { por mil } \\
\text { nascidos }\end{array}$ & $\begin{array}{r}13,16 \text { por mil } \\
\text { nascidos }\end{array}$ & $\begin{array}{r}14,20 \text { por mil } \\
\text { nascidos }\end{array}$ \\
\hline Esperança de vida ao nascer (2009) & 75,03 anos & 75,91 anos & 71,35 anos \\
\hline Estabelecimentos de saúde (2009) & 4.831 estab. & 2.541 estab. & 142 estab. \\
\hline $\begin{array}{l}\text { Percentual de pessoas que vivem em } \\
\text { domicílios com água encanada (2010) }\end{array}$ & $97,7 \%$ & $99,1 \%$ & $99,1 \%$ \\
\hline $\begin{array}{l}\text { Percentual domicílios com lixo coletado } \\
(2010)\end{array}$ & $99,6 \%$ & $99,8 \%$ & $99,3 \%$ \\
\hline $\begin{array}{l}\text { Percentual domicílios atendidos pela rede } \\
\text { geral de esgotamento sanitário (2010) }\end{array}$ & $87 \%$ & $97 \%$ & $84 \%$ \\
\hline $\begin{array}{l}\text { Percentual de pessoas em domicílios } \\
\text { subnormais }(2010)\end{array}$ & Não disponível & $11,4 \%$ & $12 \%$ \\
\hline
\end{tabular}

\subsection{Apresentação dos Casos}

\subsubsection{Aliança Empreendedora e Cooperativa Vira Lata}

Este caso aborda um projeto realizado pelo empreendimento social Aliança Empreendedora junto a uma cooperativa de reciclagem de materiais, a Vira Lata, localizada no bairro Jardim Boa Vista, no oeste do município de São Paulo. Esta iniciativa aplicou uma metodologia com o objetivo de fomentar o empreendedorismo e o cooperativismo como meios para promoção da inclusão e do desenvolvimento econômico e social.

Inicialmente, este capítulo descreve o contexto em que se situa o caso estudado, circunscrevendo o campo no qual a Aliança Empreendedora e a Vira Lata interagem e estabelecem relações com outros agentes. Os meios pelos quais o empreendimento social reúne contribuições para a iniciativa estudada são descritos a seguir. Por fim, são identificados e analisados os resultados obtidos na promoção do desenvolvimento social para os trabalhadores cooperados à Vira Lata. 


\subsubsection{O Campo: agentes e capitais}

A Aliança Empreendedora é um empreendimento social constituído como organização sem fins lucrativos que atua desde 2005 com projetos de geração de renda, negócios inclusivos e disseminação da cultura empreendedora no Brasil. Foi criada por um grupo de sete jovens, a partir de sua experiência com o empreendedorismo de baixa renda na Empresa Júnior da Universidade Federal de Curitiba. Conta com 82 profissionais que trabalham em escritórios localizados em Curitiba-PR, São Paulo-SP, Recife-PE e Salvador-BA. Desde sua fundação, a Aliança Empreendedora realizou mais de 40 projetos e serviços para empresas e governos, apoiando diretamente mais de 6.000 microempreendedores de setores variados em 12 estados brasileiros.

A Aliança Empreendedora atua em um campo - segundo Bourdieu, um espaço social formado por uma rede de relações objetivas entre diferentes agentes (BOURDIEU, 1990; MAYORAL BLASCO, 2010) - no qual a organização se relaciona com agentes do Estado, do Mercado e do Terceiro Setor, sendo a interação com agentes privados a mais expressiva e frequente. Como detalhado a seguir, cada agente detém um tipo específico de capital, entendido como atributo de poder, cuja mobilização determina as posições relativas que cada qual ocupa no campo e o tipo de interação que será estabelecida entre eles (Ibid., Ibid.).

No campo em que o empreendimento social desenvolve suas atividades, importante posição é ocupada pelas instituições responsáveis por elaborar e implementar políticas públicas que regulem, de modo geral, a ação dos microempreendimentos, e mais especificamente, os setores nos quais a atuação da Aliança Empreendedora é mais proeminente, como negócios inclusivos e geração de renda. A influência exercida pelas instituições e sistemas políticos com poderes reconhecidos pelos agentes do campo se dá pela mobilização de capital político. Essa mobilização, que se traduz em poder regulatório, pode determinar a existência de oportunidades ou de barreiras à ação dos microempreendimentos e, por conseguinte, interferir na abrangência dos resultados das intervenções realizadas pela Aliança Empreendedora junto a estes agentes. 
O capital financeiro - recursos financeiros de origem pública ou privada destinados às ações realizadas no campo - é mobilizado por agentes privados que interagem com o empreendimento social, sobretudo no financiamento de projetos e na compra de serviços. Em geral, são grandes empresas que intencionam criar modelos de negócios inclusivos junto aos públicos de baixa renda, implantar programas, projetos e editais, ou realizar palestras, cursos, vivências e treinamentos em temas relacionados a empreendedorismo de baixa renda, negócios inclusivos, geração de trabalho e renda, estratégias de desenvolvimento econômico e social e inovação junto à base da pirâmide. Os projetos financiados também incluem a geração de conhecimento e o desenvolvimento de metodologias relativas ao empreendedorismo de baixa renda, negócios inclusivos e educação empreendedora. Governos estaduais e municipais também interagem com a Aliança Empreendedora, estabelecendo parcerias, financiamento de projetos e compra de serviços nestas áreas, tendo em vista a implantação de políticas públicas voltadas para o fomento do empreendedorismo, a geração de renda e a gestão de resíduos sólidos. Alinhada a estes agentes, a mídia ocupa importante papel no campo, divulgando a metodologia da Aliança Empreendedora pela inserção em programa de grande audiência da TV aberta, além da divulgação de ações e publicação de artigos.

Muitos empreendimentos sociais e organizações sem fins lucrativos figuram como agentes no campo, em interação com a Aliança Empreendedora ou com os empreendimentos apoiados. Mobilizam, sobretudo, capital intelectual - o know-how que fundamenta as ações realizadas no campo, por meio da troca de experiências, da criação de metodologias e inovações, e da exploração de novas oportunidades de negócios, ocasionalmente contribuindo com capital financeiro para a realização das ações. O projeto Geração Y, por exemplo, é relatado como o resultado da soma de sonhos e metodologias da Aliança Empreendedora e da Ashoka no desenho de um programa único que integra empreendedorismo econômico e empreendedorismo social para jovens que queiram começar a empreender negócios ou realizar projetos sociais.

A Aliança Empreendedora apóia empreendedores individuais, microempreendedores, grupos produtivos comunitários urbanos e rurais, jovens empreendedores e catadores de materiais recicláveis. Ela interage com estes agentes aplicando o capital intelectual que detém, ou seja, metodologia, know-how e acesso à ampla rede de agentes com os quais se relaciona. Oferece 
metodologias de estímulo e apoio ao empreendedorismo de baixa renda e a negócios sociais comunitários, além de assessorias e capacitações em projetos geralmente financiados por empresas privadas ou governos. Também mantém disponíveis vídeos e conteúdos educativos sobre gestão e empreendedorismo (AprendaE), um canal de ensino a distância (Escalada Empreendedora Online), um mapa de apoio para a busca de parceiros e um portal de crowdfunding (Impulso). Anualmente, realiza o Prêmio Aliança de Empreendedorismo Comunitário, para promover e reconhecer casos bem-sucedidos de microempreendedores brasileiros.

Interações mais complexas no campo envolvem articulações entre a Aliança Empreendedora, empresas privadas, organizações sem fins lucrativos, instâncias governamentais e microempreendimentos, como o Projeto Eco Cidadão. Com uma metodologia que visa fortalecer organizações de catadores de materiais recicláveis em Curitiba e integrá-las aos programas municipais de coleta e destinação de resíduos, este projeto busca implantar Parques de Recepção de Recicláveis onde, além de toda a infraestrutura de máquinas e equipamentos, as organizações de catadores recebem assessoria e treinamento em classificação e separação de materiais, em gestão, vendas, empreendedorismo e negociação. Esta interação busca equilibrar, no campo, a influência exercida por instituições e sistemas políticos (o capital político detido pela Prefeitura Municipal de Curitiba e pelo Movimento Nacional dos Catadores de Materiais Recicláveis - MNCR), o aporte de metodologia e know-how (o capital intelectual mobilizado pela Aliança Empreendedora, Fundação Avina e também o MNCR), o conjunto de capacidades (capital humano das Associações e Cooperativas de Catadores) e o poder econômico (capital financeiro de empresas privadas que comercializam materiais com estas organizações, além do capital financeiro aportado por apoiadores privados).

Em 2011, a Aliança Empreendedora iniciou o trabalho com cooperativas de reciclagem de resíduos sólidos no estado de São Paulo. O projeto Reciclagem Inclusiva é desenvolvido em 10 cidades brasileiras, em parceria com as financiadoras do projeto: uma grande siderúrgica de aço e a GIZ - Agência de Cooperação Internacional do Governo da Alemanha. Seu objetivo é o apoio e a inclusão de organizações de catadores de materiais recicláveis como fornecedores de matéria-prima na cadeia produtiva daquela empresa.

A Cooperativa Vira Lata foi uma das participantes do projeto Reciclagem Inclusiva e parceira comercial da empresa que financia o projeto, para quem vende os materiais ferrosos que 
coleta e tria. As atividades desta cooperativa tiveram início em 1998, por meio da mobilização de habitantes do Jardim Boa Vista, quando ainda era um bairro carente de infraestrutura e equipamentos básicos. Visando minimizar a falta de trabalho para moradores locais e lidar com a questão do descarte inadequado do lixo na região, inicialmente a cooperativa recebia e triava materiais trazidos por "carrinheiros" (catadores autônomos) em um espaço na igreja católica do bairro. Para aumentar o volume de materiais coletados e oferecer melhor qualidade de vida ao trabalhador, ao longo do tempo, a cooperativa deixou de realizar a coleta através de carrinheiros e passou a investir em caminhões próprios. Chegou a ter 100 cooperados, mas a crise de 2008 impactou a operação da Vira Lata a ponto de perderem o galpão no qual realizavam suas atividades. Foi temporariamente transferida para Pirituba e retornou à sua região de origem em 2011, quando passou a administrar um dos maiores centros de reciclagem da cidade de São Paulo. Em março de 2012, tinha 60 cooperados e a perspectiva de chegar a 200 com o aumento do volume de material coletado.

O campo no qual a Aliança Empreendedora desenvolveu o projeto de apoio à Cooperativa Vira Lata é composto por agentes que detêm diferentes tipos de capital, como representado na Ilustração 1. As interações estabelecidas entre os agentes tendem a ser bastante influenciadas pelo capital financeiro, o qual representa o principal regulador da ação dos agentes no campo, de caráter predominantemente econômico. 


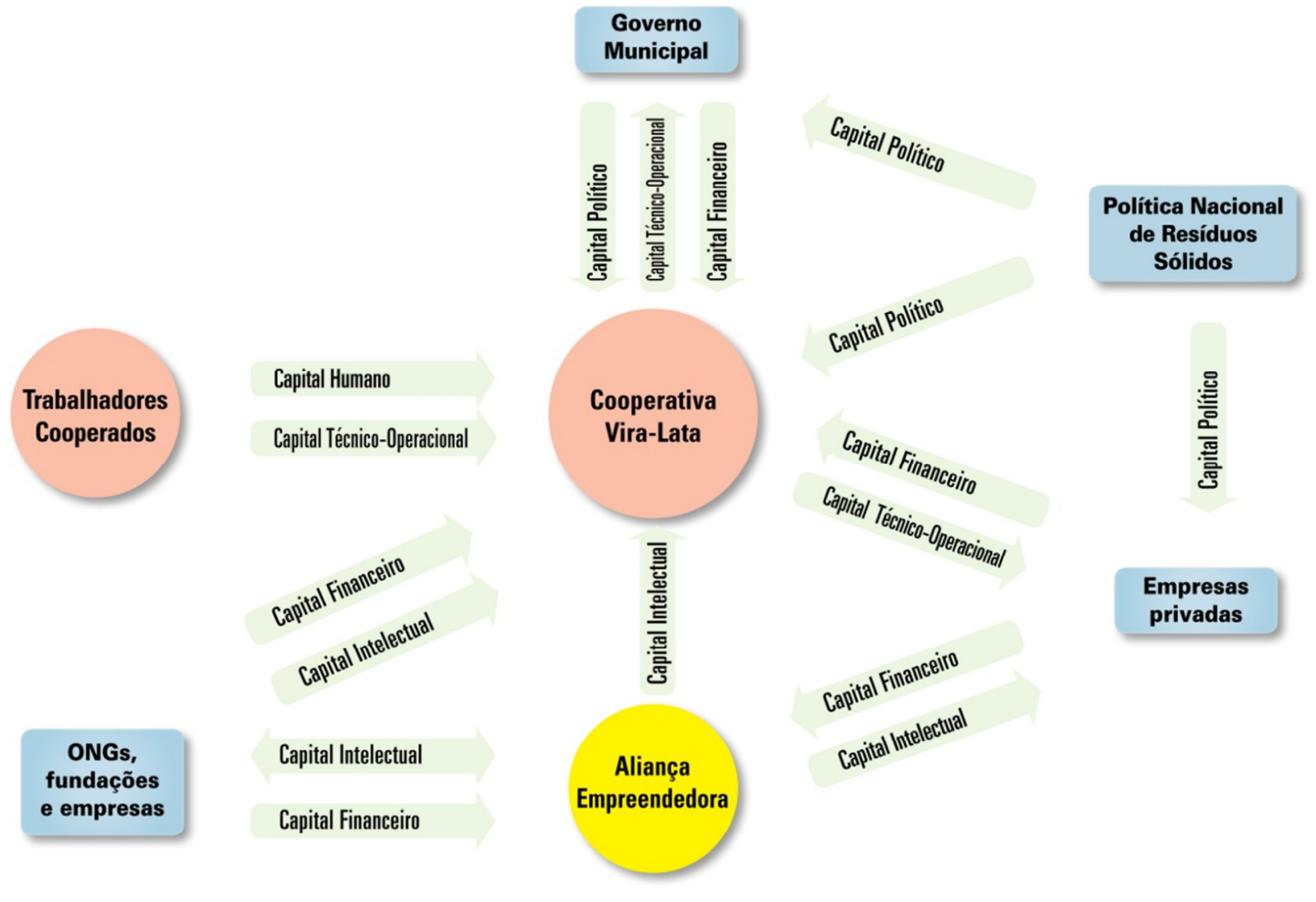

A Cooperativa Vira Lata mobiliza capital humano, ou seja, o conjunto de capacidades que permitem aos trabalhadores cooperados desenvolverem seu potencial, aproveitarem oportunidades e realizarem ações conjuntas e integradas no campo. Também mobiliza capital técnico-operacional, a capacidade técnica instalada, associada à capacidade de execução de uma ação efetiva no campo. Sua interação no campo se dá com agentes que mobilizam capital financeiro (os recursos empregados na destinação ou na compra dos materiais recicláveis), com agentes que detêm o capital político (que regula o setor em que a cooperativa atua e apoia sua operação) e com agentes que mobilizam capital financeiro e/ou intelectual para desenvolvimento e fortalecimento institucional da Vira Lata.

Mobilizando o capital técnico-operacional do campo, os trabalhadores são todos cooperados e realizam atividades em funções diversas. Alguns são catadores de materiais que trabalhavam em lixões ou nas ruas, mas nem todos são oriundos deste setor. Alguns deixaram empregos 
em organizações comerciais atraídos por remuneração mais alta, embora com menos benefícios. O capital humano presente na cooperativa fundamenta-se na identidade organizacional e na valorização do trabalho realizado pelos cooperados, mas ainda é frágil do ponto vista do associativismo e da autogestão.

Outros agentes detentores de capital social e político local têm pouca influência no campo, atuando pontualmente. A Igreja Católica local teve importante papel ao ceder espaço físico e apoio para as atividades iniciais da cooperativa, ainda informais, mas hoje está distanciada. As Associações de Moradores dos bairros da região colaboram apenas por meio da divulgação de oportunidades de trabalho para a população. A cooperativa também recebe apoio pontual de ONGs em projetos de capacitação.

O capital financeiro está presente nas parcerias e alianças estabelecidas com a Cooperativa Vira Lata para sua inserção em cadeias produtivas. No setor de sucata ferrosa, a cooperativa recebe uma grande quantidade de material recolhido em cerca de 60 oficinas autorizadas de uma empresa de seguros automotivos, além de latinhas oriundas da coleta residencial e materiais de outras fontes em menor volume. Toda esta sucata é comprada pela siderúrgica, que a utiliza como insumo para sua produção de aço. No setor de vidros, com apoio financeiro de uma empresa do setor de bebidas, a Vira Lata recolhe garrafas em bares e restaurantes, e vende o vidro triturado a uma empresa de embalagens de vidro. No setor de papéis, a coleta comercial é feita junto a grandes geradores, como uma editora e um grande edifício comercial, privilegiando-se o papel branco. A importância do capital financeiro mobilizado por este tipo de agentes para a estabilidade no campo e a dependência da cooperativa são ressaltadas na análise a seguir:

Este cenário reforça a importância das parcerias com o setor privado para a sustentabilidade das cooperativas, uma vez que garante quantidade, qualidade e diversidade de materiais. O que vem fortalecendo o Projeto Vira Lata são os acordos com os grandes geradores de materiais recicláveis e com compradores.[...] Nas empresas, a cooperativa coleta material limpo, praticamente livre de rejeito, ganhando tempo, qualidade e gerando mais receita. Além disso, há um ganho de escala: uma única viagem de caminhão coleta, em uma empresa, o mesmo que seria recolhido em 4 a 5 condomínios. (Relatório Práticas Sustentáveis: experiências na cadeia da reciclagem)

As parcerias com grandes empresas também geram visibilidade para a Cooperativa, abrindo portas para novos negócios. 
Já parceira da Cooperativa, a siderúrgica pode proporcionar-lhe assessoria e capacitação pela Aliança Empreendedora. Desta forma, o agente detentor do capital financeiro que foi mobilizado na relação comercial com a cooperativa assumiu um papel de agente financiador (do projeto de Reciclagem Inclusiva) e mobilizador de capital intelectual, aportado pela Aliança. Interações como esta, entretanto, são bem pouco frequentes no campo, e os agentes tendem a manter posições estáticas determinadas pelo principal capital que detêm.

A Aliança Empreendedora é um agente que mobiliza capital intelectual, oferecendo metodologia para o fortalecimento institucional da cooperativa, através de assessoria e treinamento em classificação e separação de materiais, em gestão, vendas, empreendedorismo e negociação. Assim como a Aliança Empreendedora, outros agentes mobilizam capital intelectual e/ou financeiro para o desenvolvimento e fortalecimento institucional da Cooperativa Vira Lata. A aquisição dos primeiros equipamentos só foi possível através de parcerias feitas com a Petrobrás e com a Fundação Banco do Brasil. De modo geral, esses agentes estabelecem interações pontuais, focadas e de curta duração, as quais contribuem para o fortalecimento dos capitais humano e técnico-operacional da cooperativa, mas pouco interferem nas dinâmicas que se desenvolvem no campo.

O capital político presente no campo é exercido pela Prefeitura do Município de São Paulo e por atores sociais que visam fortalecer a ação dos catadores, suas associações e cooperativas, como o MNCR (Movimento Nacional dos Catadores de Materiais Recicláveis), que mantém atuação incisiva na esfera federal, contribuindo para a construção de macropolíticas no setor, além de atuações locais. Entretanto, não foi identificada influência direta no campo onde se insere o caso em estudo.

Responsáveis pelas políticas de gestão de resíduos sólidos nos municípios, as prefeituras podem exercer importante papel no fortalecimento do capital técnico-operacional e social das cooperativas locais, fortalecendo suas interações e suas posições no campo. O Programa de Coleta Seletiva Solidária da Prefeitura de São Paulo foi implantado em 2003, baseado na inclusão de organizações de catadores no gerenciamento das centrais de triagem de recicláveis (JACOBI; BESEN, 2011), como é o caso da Cooperativa Vira Lata. Neste modelo, o convênio entre a prefeitura e a cooperativa assegura o local em que a organização opera, o fornecimento de uniformes e a cobertura dos custos de manutenção do espaço, como água, luz 
e, se for o caso, IPTU. A parceria com a prefeitura municipal também assegura cinco caminhões para coleta residencial e condominial, além de parte da coleta seletiva efetuada pela empresa prestadora de serviços na região. Desta forma, ao exercer seu capital político, a Prefeitura Municipal mobiliza capital financeiro, que influencia a atuação dos agentes operacionais no campo.

Potencial fonte de capital político e financeiro, a Política Nacional de Resíduos Sólidos, recentemente aprovada (Lei $\mathrm{n}^{\circ} 12.305$, de 2 de agosto de 2010), regula a gestão integrada e o gerenciamento de resíduos sólidos, inclusive os perigosos, sob responsabilidade dos geradores e do poder público, além dos instrumentos econômicos aplicáveis. O impacto desta lei no campo se configura como uma oportunidade para o fortalecimento das cooperativas e associações de catadores, sobretudo no trabalho associado a políticas municipais de gestão de resíduos.

\subsubsection{Disposições do campo}

"Fazer da economia um lugar para todos" - visão da Aliança Empreendedora -, é uma frase que sintetiza as disposições presentes no campo onde o empreendimento social e outros agentes desenvolvem suas atividades, apoiando e interagindo com a Cooperativa Vira Lata.

Reduzir o desemprego e o subemprego, propiciando melhores condições de trabalho e renda são fatos que mobilizam diferentes agentes - cooperados, parceiros comerciais, governo local, ONGs e empreendimento social - a interagirem no campo, criando oportunidades para que uma parcela da população tenha condições de se inserir na economia formal pelo empreendedorismo que, no caso, se traduz em uma cooperativa de catadores de materiais recicláveis.

A Cooperativa Vira Lata se propõe a organizar meios de geração de trabalho e renda aos desempregados através da reciclagem, como forma de inclusão social, e despertar a sociedade para os problemas ambientais.(Site Institucional)

A crença de que é possível aliar conscientização ambiental, reciclagem e geração de renda, em tempos onde a promoção do desenvolvimento sustentável é uma temática muito presente, é forte mobilizadora para a ação dos agentes econômicos e políticos no campo. Pressionados a 
melhorar a gestão de resíduos gerados nas cidades e pelas empresas, os agentes que interagem no campo estabelecem relações que visam aliar ganhos econômicos e de imagem à geração de valor social.

Por sua vez, cooperativa e cooperados têm como pressuposto para a ação no campo o reconhecimento e a valorização de suas qualidades para, através do trabalho eficiente e profissionalizado, estabelecer parcerias e relações comerciais com agentes públicos e privados, concretizando os objetivos socioambientais que ambos perseguem.

Mas aspectos de cultura organizacional influenciam vigorosamente o modo como a cooperativa interage no campo. Ao comporem um grupo marginalizado, historicamente vítima de preconceitos e de ações mal intencionadas, os catadores se caracterizam pela vulnerabilidade e pelo individualismo. Esta condição dificulta a internalização dos ideais inerentes ao cooperativismo, sobretudo a gestão compartilhada. A convivência no grupo é difícil e ele se fragmenta em subgrupos que se diferenciam e competem entre si, embora valorizem uma identidade comum de humildade e de coletividade. Com o cooperativismo pouco desenvolvido, a organização esteve sujeita a problemas em sua governança e transparência. Evidencia-se que o capital humano e o capital político encontram-se pouco desenvolvidos na cooperativa, a qual passa a atuar no campo mobilizando capital técnicooperacional e financeiro. Essa posição no campo é reforçada pela atuação dos demais agentes, cuja expectativa é de que a cooperativa opere com eficiência, garantindo o respeito pelos compromissos assumidos.

Mesmo abrindo mão do mito do cooperativismo, os agentes se articulam de modo a fortalecer o empreendedorismo em um grupo de pessoas com uma história de construção de possibilidades, de luta pela valorização do trabalho, de criação de uma identidade comum e de mobilização de recursos para aproveitamento de oportunidades. Ou seja, os agentes operam no campo,de modo a identificar e potencializar a ação de um agente cuja trajetória confere credibilidade e legitimidade à sua atuação e à sua capacidade de ingressar em cadeias produtivas, criando valor econômico e condições para a melhoria da qualidade de vida dos trabalhadores. 


\subsubsection{Contribuições do Empreendimento Social}

A Aliança Empreendedora desenvolve trabalhos com cooperativas e associações de catadores de materiais recicláveis desde 2008, quando teve início o Projeto EcoCidadão em Curitiba. A inclusão destes trabalhadores da economia formal e o impacto na renda pessoal são mais viáveis através destas formas organizativas, considerando que os melhores preços são obtidos com maiores volumes e melhor qualidade do material. Por essa razão, a Aliança Empreendedora investe em metodologias de fortalecimento de cooperativas e associações.

O trabalho com catadores avulsos permanece uma questão a ser equacionada $\mathrm{e} o$ empreendimento social está atento a isso. Fruto de sua experiência com grupos produtivos, a Aliança Empreendedora abriu uma nova frente de ação voltada para empreendedores individuais, visando atender a um público que não tem intenção ou habilidade para associar-se a outros. No setor de reciclagem, esta pressão existe, pois a maioria dos catadores trabalha de forma independente, em condições precárias de segurança e saúde nas ruas da cidade (JACOBI; BESEN, 2011), mas prefere não se associar. Na opinião de um dos fundadores da Aliança Empreendedora, é necessário compreender que nem todos os empreendedores ou catadores se adaptam aos modelos disponíveis para seu fortalecimento; são os modelos e empreendimentos sociais que devem constantemente se adaptar a estes atores.

O know-how desenvolvido desde 2008 no Projeto EcoCidadão, realizado junto a cooperativas e associações de catadores de materiais recicláveis, foi refinado e aplicado à Cooperativa Vira Lata no ano de 2011. Através de um programa de assessoria e treinamento, os cooperados tiveram acesso a informação e orientação sobre os materiais que reciclam, gestão e empreendedorismo, conflito e trabalho em grupo. Além de melhorar a qualidade da produção, o apoio teve como objetivo fortalecer a gestão com uma linguagem acessível para o públicoalvo - pessoas com níveis de escolaridade bastante baixos e pouca ou nenhuma vivência em organizações complexas.

A metodologia aplicada pelo empreendimento social partiu de um diagnóstico e identificação de melhorias nos processos de gestão, produção e parcerias/comercialização de produtos da Cooperativa Vira Lata. O plano de ação originado neste diagnóstico envolve a realização de oficinas periódicas após o expediente, com duração de uma hora. Envolve também um plantão semanal exercido por um técnico da Aliança Empreendedora para assessorar, in loco, a gestão 
da cooperativa. O diagnóstico é reaplicado a cada seis meses como forma de monitorar o plano de ação e planejar novas oficinas e atividades.

A principal contribuição aportada pela Aliança Empreendedora na Vira Lata foi o adensamento de uma cultura cooperativista. Conhecer o modelo de funcionamento de uma cooperativa, direitos e deveres, governança e transparência, são ganhos apontados pelos trabalhadores. Treinamentos anteriores ou conhecimento prévio sobre o tema foram reavivados e postos em prática, através das atividades realizadas pela equipe técnica da Aliança Empreendedora. O "fazer junto" foi importante para concretizar fundamentos e práticas do cooperativismo, através da elaboração e do monitoramento de planos de ação, atividades que foram acompanhadas por oficinas a fim de suprir as lacunas identificadas.

O projeto realizado pela Aliança Empreendedora foi encerrado no início de 2012. Na cooperativa, existe a intenção de que as oficinas e capacitações continuem a ser realizadas, talvez com a utilização de outras metodologias. Mas é bastante provável que o processo não tenha continuidade, caso dependa exclusivamente da pró-atividade e da capacidade de execução por iniciativa dos próprios cooperados, em parte porque não receberam treinamento para isso, dada a curta duração do projeto, e em parte porque resiste uma cultura de dedicação integral à produção, em detrimento do desenvolvimento e da gestão.

Importante contribuição foi aportada pela Aliança Empreendedora no processo de socialização dos cooperados. Em geral, os trabalhadores são oriundos de diferentes bairros e não têm oportunidade de interagir e construir relações fora do ambiente de trabalho. As capacitações oferecidas por meio de oficinas criaram condições para o grupo se relacionar, destacando-se os momentos de descontração e troca, assim como de compartilhamento de duras experiências de vida. Esses momentos constituíram um embrião de fomento do capital social, propiciando espaços para criação de confiança e superação de preconceitos. De fato, as metodologias desenvolvidas pela Aliança Empreendedora contemplam a integração dos empreendedores nas ações de capacitação, ainda que continuem desenvolvendo seu trabalho de forma individual e individualista. Essa convicção é mantida pelo pressuposto de que a integração gera uma identidade própria e identidade gera resiliência. No caso dos catadores, conforme relato de um dos fundadores da Aliança Empreendedora, há ganhos em qualidade de vida, motivação e menos casos de depressão. 


\subsubsection{Resultados para o desenvolvimento social}

O impacto pretendido pela Aliança Empreendedora é a geração de oportunidades de trabalho, renda e educação, promovendo melhorias na qualidade de vida e desenvolvimento socioeconômico através da inclusão de pessoas e grupos de baixa renda na economia formal. O fortalecimento das cooperativas de catadores de materiais recicláveis se insere nessa perspectiva, visando qualificar e melhorar a produção e a gestão destes empreendimentos.

Desde que começou a operar, a Cooperativa Vira Lata vem atingindo seu objetivo básico, que é contribuir para a preservação do meio ambiente com geração de trabalho e renda. Embora tenha tido problemas em sua gestão e a continuidade ameaçada ao longo dos anos, a Vira Lata tem mantido um bom nível de remuneração mensal e o valor-hora pago aos cooperados vinha crescendo mensalmente durante o período de realização do estudo - em 2012, passou de $\mathrm{R} \$$ 3,30 em janeiro para $R \$ 4,02$ em fevereiro e para $\mathrm{R} \$ 4,16$ em março. Isso representa uma renda em torno de $\mathrm{R} \$ 670,00$ por 40 horas semanais/mês ou pouco mais de um salário mínimo. Esse valor já foi bem superior e existe a percepção de que o valor atual está abaixo do ideal, embora seja suficiente para suprir as necessidades dos cooperados. A principal meta da cooperativa é aumentar a quantidade de materiais comercializados e, consequentemente, melhorar a remuneração dos cooperados, chegando a R\$1200,00/mês.

O nível de renda propiciado pela cooperativa fez com que ela se tornasse uma opção de trabalho, não apenas para pessoas desempregadas ou que viviam da coleta de materiais nas ruas e lixões, mas também para profissionais qualificados que trabalhavam em empresas de diversos segmentos, como costureiras, cozinheiras e auxiliares de serviços gerais.Em busca de renda líquida maior, por vezes o dobro, profissionais que saíram do mercado de trabalho convencional e optaram por trabalhar na cooperativa abriram mão da contratação em regime CLT, com todas as suas garantias, benefícios adicionais ao salário, como cesta básica, além da participação no sistema público de seguridade social (INSS). Os cooperados recebem alimentos e roupas, como "benefícios" esporadicamente doados por parceiros comerciais da Vira Lata. Prevalece o entendimento de que o montante financeiro recebido ao final de cada mês, acrescido de doações eventuais, compensa a mudança na forma de contratação, mesmo que esse rendimento seja insuficiente para compensar as garantias sociais e os benefícios perdidos. Neste cenário, é possível identificar a valorização do trabalho no mercado de 
reciclagem, e consequente aumento da renda líquida individual, fomentando o desenvolvimento na esfera da riqueza material. Entretanto, esse desenvolvimento vem acompanhado por indicadores de precarização do trabalho, como o abandono de carreiras profissionais, a desvalorização de direitos do trabalhador e a aceitação de que doações filantrópicas, destinadas à cooperativa e aos cooperados, sejam naturais no sistema econômico que caracteriza este campo.

Em outros casos, o trabalho na cooperativa representa a possibilidade de capacitação para uma profissão, o que é fato, sobretudo para os cooperados que estão há mais tempo na Vira Lata e que tiveram possibilidade de ascender a funções mais complexas. O desenvolvimento de competências para comercialização, roteirização, operação de máquinas e coordenação do trabalho pode garantir a estas pessoas oportunidades de emprego inatingíveis antes de participar da cooperativa, e pode representar possibilidades de aumento em sua renda. Esse tipo de indicador associado à riqueza material é, em última instância, a essência do que é buscado pela Aliança Empreendedora, no sentido do desenvolvimento de competências para empreender. Busca-se fortalecer as pessoas que trabalham com materiais recicláveis, criando condições para que possam operar satisfatoriamente as associações ou cooperativas às quais estão ligadas ou para que possam, alternativamente, qualificar-se para outras atividades ou empregos. Para o empreendimento social, o aumento na renda deve ser consequência desse desenvolvimento. Desta forma, o acesso à capacitação profissional oferecido pela Aliança Empreendedora também contribui, por si só, para a promoção do desenvolvimento na esfera do bem estar social.

De modo geral, a coleta de materiais recicláveis é a única opção de trabalho ao longo da vida, ou é a "sina", conforme relata uma trabalhadora. Segundo ela, a coleta representa, para os cooperados, a possibilidade de sobreviver e acessar bens de consumo para si e sua família. Muitas vezes responsáveis pela renda familiar, esses cooperados alcançaram e procuram manter um padrão de vida digno, que vai desde a possibilidade de comprar os alimentos de que necessitam diariamente, até a construção e ampliação de suas residências. Embora, nestes casos, as evidências apontem para o desenvolvimento na esfera do bem-estar social, verificase que estes resultados nem sempre são decorrentes da ocupação na Vira Lata e estão muito mais associados à obstinação pessoal em realizar um esforço de trabalho, ainda que aparentemente os catadores sejam mais bem remunerados ao serem cooperados do que se trabalhassem sós nas ruas ou lixões. 
O trabalho na cooperativa é braçal e realizado predominantemente por mulheres, exigindo muita força física - isso tem gerado a intensificação de problemas de saúde de algumas cooperadas. Em sua maioria, essas pessoas desacreditam do sistema público de saúde, pois, embora tenham recorrido a ele em várias ocasiões, não conseguiram diagnóstico e tratamento adequados. Quando possível, pagam por exames e outros procedimentos, visando diminuir os prazos de atendimento que caracterizam o serviço público, os quais poderiam ter espera de até um ano, segundo as entrevistadas. Portanto, o acesso a programas de proteção e promoção da saúde, inerentes ao desenvolvimento na esfera do bem-estar social, praticamente inexiste para estas pessoas.

Os indicadores de melhoria na qualidade de vida, como alimentação, saúde e educação sequer são valorizados por muitos destes trabalhadores, os quais parecem viver unicamente em busca da sobrevivência. Ainda assim, uma trabalhadora de idade avançada atribui à sua condição na cooperativa a oportunidade de desfrutar de mais descanso e de melhor organização da vida diária do que quando coletava materiais nas ruas. Portanto, conceder o acesso a trabalho digno para pessoas de diferentes origens, gêneros e idades é uma forma de propiciar condições que melhorem alguns indicadores de bem estar social das pessoas que ingressam na cooperativa, ainda que isso não seja percebido por todos eles.

A Aliança Empreendedora contribuiu para que a cooperativa propiciasse as condições de desenvolvimento nas esferas de riqueza material e de bem estar social relatadas, ainda que não decisivamente. As evidências indicam que essa contribuição se deu pelo fortalecimento da governança e da transparência da cooperativa, em um contexto de mudança de gestão que facilitou o desenvolvimento, ainda que incipiente, de mecanismos voltados para a eficiência administrativa e autogestionária. A relação entre comercialização e remuneração tornou-se mais clara para os cooperados. Decisões diversas, como a forma mais justa de remunerar as pessoas e aperfeiçoamentos no estatuto da cooperativa também promoveram impactos diretos por parte do apoio oferecido pelo empreendimento social. A organização do trabalho melhorou, assim como o foco na valorização e manutenção de parcerias.

O embrião do associativismo, embora presente nas práticas de gestão atuais da Cooperativa Vira Lata e fomentado pela ação da Aliança Empreendedora, não se traduz em criação de 
capital social e político entre os cooperados. Ao contrário, as pessoas demonstram não ter interesse e disponibilidade para envolver-se em atividades que sinalizem o desenvolvimento na esfera do empoderamento, como a participação política e social em instâncias da sociedade civil, em programas governamentais e atividades culturais, por exemplo. O acesso a equipamentos públicos, tidos como ineficientes, é realizado nos patamares comuns à maioria da população: os filhos dos cooperados estão matriculados no ensino público; o acesso a programas de saúde é feito em casos emergenciais ou agudos; a compra destes e de outros serviços é tida como aceitável e realizada quando possível; a moradia é um mérito pela capacidade e pelo esforço de trabalho individual.

Do ponto de vista do desenvolvimento local, a inexistência de indicadores de empoderamento das pessoas para pleno exercício de seus direitos civis revela alguns limites das contribuições que a Aliança Empreendedora, indiretamente, e a Cooperativa Vira Lata, mais diretamente, oferecem para o grupo de pessoas que fazem parte dessa iniciativa. Não se evidenciam contribuições voltadas para promoção e o fortalecimento do capital social e do capital cultural, propostos por Kliksberg (1997, 2007) como importantes alicerces para o desenvolvimento social. Há que se considerar, entretanto, os limites colocados pelos objetivos dos dois empreendimentos e o alcance do projeto realizado em parceria, cujo foco reside na geração de renda para a população. O empoderamento das pessoas seria, então, um ganho secundário da ação, possível e viável, mas ainda pouco explorado.

O "desenvolvimento includente" tal como preconizado por Sachs (2004), tem sido promovido na medida em que os cooperados da Vira Lata têm acesso a oportunidades de emprego e renda, embora esse fato seja desvinculado de políticas distributivas que caracterizam as facilidades econômicas como uma das liberdades instrumentais propostas por Sen (2000). Mas, muito provavelmente por não experimentarem a completa remoção de condições que causam a privação de liberdades, no sentido colocado por Sen (2000, 2007, 2008), essas pessoas não se encontram em condições de, por meio do exercício de seus direitos civis, obterem acesso a serviços públicos de qualidade e fortalecimento do capital social.

No caso estudado, o conjunto de ações realizadas pelo empreendimento social e pela cooperativa resulta em aumento das oportunidades para que as pessoas abrangidas pela iniciativa conheçam a melhoria em alguns indicadores de riqueza e bem-estar, com avanços significativos nas condições de sobrevivência e de qualidade de vida. Entretanto, a 
desigualdade no acesso a oportunidades e a assimetria de poder que caracteriza o contexto socioeconômico em que vivem permanecem como fatores que representam barreiras à promoção do desenvolvimento social.

\subsubsection{Fundo Zona Leste Sustentável}

Este caso descreve a ação do Fundo Zona Leste Sustentável, um empreendimento social criado com o objetivo de contribuir para a promoção do desenvolvimento social em âmbito territorial nos distritos de São Miguel Paulista, Ermelino Matarazzo e Itaim Paulista, localizados no extremo leste do município de São Paulo. Iniciativa pioneira, inspirada em modelos de fundos comunitários, visa dinamizar a economia local por meio da mobilização de diversos atores, recursos e competências. A primeira edição do Fundo, a qual foi objeto deste estudo, proporcionou investimento de recursos financeiros, formação técnica e assessoria para 12 empreendimentos de pequeno porte atuantes na região.

Inicialmente, este capítulo descreve o contexto em que se situa o caso estudado, circunscrevendo o campo no qual o Fundo é constituído, as interações estabelecidas entre diferentes agentes e entre o Fundo e os empreendimentos por ele contemplados. Os meios pelos quais o empreendimento social promove contribuições na iniciativa estudada são descritos a seguir. O capítulo termina com a identificação e análise dos resultados obtidos na promoção do desenvolvimento social em âmbito local.

\subsubsection{O Campo: agentes e capitais}

O Fundo Zona Leste Sustentável é um fundo comunitário gerido por organizações da sociedade civil, iniciativa privada, poder público e lideranças locais dos distritos de São Miguel Paulista, Ermelino Matarazzo e Itaim Paulista, situados no extremo leste da capital de São Paulo. Foi criado em 2010 com a missão de canalizar recursos de pessoas físicas e jurídicas com interesse em contribuir para a região e aplicá-los de forma monitorada em iniciativas produtivas locais, permitindo que atinjam competitividade no mercado e gerem oportunidades duradouras de trabalho e renda no território. 
O Fundo Zona Leste Sustentável foi concebido pela Fundação Tide Setúbal no contexto de formação, articulação e fortalecimento de iniciativas locais da região de São Miguel Paulista, onde a Fundação desenvolve atividades desde 2006. Seu objetivo é contribuir para o desenvolvimento local de forma sustentável, promovendo o fortalecimento das instituições e o empoderamento da população local, em busca de melhor qualidade de vida no território. Atuando em parceria com a comunidade e com o Estado, a Fundação desenvolve ações em três frentes: gestão de espaços públicos (Clube da Comunidade e Galpão de Cultura e Cidadania); núcleos de formação; e mobilização e articulação da comunidade.

O primeiro edital do Fundo Zona Leste Sustentável foi lançado em outubro de 2010 para micro e pequenos empreendedores do setor de produção de bens e serviços situados nos distritos de sua abrangência. Dos 42 projetos inscritos, foram selecionados 12 empreendimentos dos segmentos de alimentação, meio-ambiente, comunicação, contabilidade e confecção. Cada projeto selecionado recebeu um investimento de até $\mathrm{R} \$ 50$ mil para aprimorar seu modelo de negócio, além de capacitação profissional, com cursos e acompanhamento técnico ao longo de um ano. O investimento totalizou cerca de R $\$ 350$ mil.

O modelo de operação do Fundo prevê a participação ativa de diferentes atores na gestão e na implementação de suas atividades. Esses atores interagem de forma integrada no âmbito do próprio Fundo, em redes de relações objetivas que constituem um espaço social, o qual se caracteriza como um campo, conforme acepção de Bourdieu (BOURDIEU, 1990; MAYORAL BLASCO, 2010). Os agentes no campo são organizações e instituições parceiras, oriundos de diferentes setores - privado, público e sem fins lucrativos, que mobilizam diferentes tipos de capitais, ou seja, atributos de poder que determinam as posições relativas que ocupam no campo e o tipo de interação que estabelecem entre si (Ibid.). A relação entre os agentes e a mobilização de diferentes capitais têm duas finalidades: garantir a consolidação e a governança do próprio Fundo, e contribuir para o aperfeiçoamento dos negócios apoiados pelo Fundo. Essa articulação constitui o campo representado na ilustração 2: 


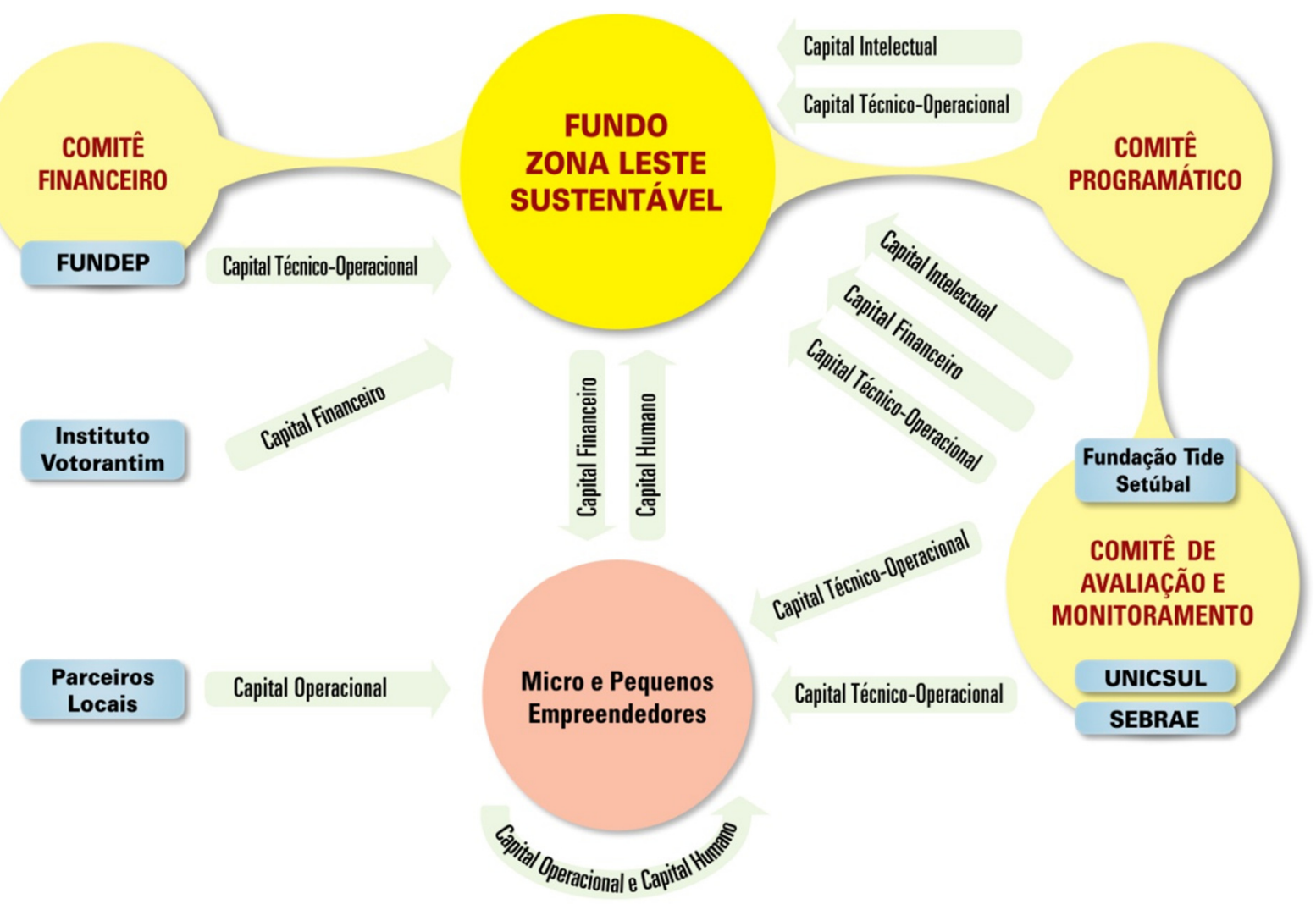

Ilustração 2 - Interações dos Agentes no Campo

Os agentes responsáveis pela existência do Fundo Zona Leste Sustentável se aglutinam em duas instâncias estruturalmente ligadas ao próprio Fundo: O Comitê Programático e o Comitê Financeiro. A participação nestes foros se dá por meio da mobilização de capital técnicooperacional, ou seja, da capacidade técnica instalada em cada membro dos comitês, associada à capacidade de uma ação efetiva no campo.

O Comitê Financeiro é composto pela Fundação Tide Setúbal, investidores financeiros e pela FUNDEP - Fundação de Desenvolvimento da Pesquisa, entidade vinculada à Universidade Federal de Minas Gerais. É a instância responsável pela gestão financeira do Fundo, mobilizando capital técnico-operacional ao realizar controle administrativo-financeiro, investimentos e perpetuação da rentabilidade do Fundo, prestação de contas, aprovação e acompanhamento do repasse de recursos, além de manter os investidores informados e cientes 
de toda a movimentação e tomada de decisões. A FUNDEP responde pela gestão dos recursos e pelo controle administrativo-financeiro dos projetos selecionados.

O Comitê Programático é formado por um grupo de agentes oriundos da área de influência do Fundo. Em sua primeira edição ${ }^{12}$, compunham esta instância: Associação Comercial de São Paulo; Escola de Artes, Ciências e Humanidades da USP Leste; Fórum para o Desenvolvimento da Zona Leste; Fundação Tide Setúbal; Instituto Ethos de Empresas e Responsabilidade Social; Lideranças comunitárias e Movimento Nossa Zona Leste; SEBRAE-SP; Secretaria Municipal de Desenvolvimento Econômico e do Trabalho; Subprefeitura de São Miguel Paulista e UNICSUL (Universidade Cruzeiro do Sul), a qual ocupa o cargo de Presidente do Comitê. Esse foro é responsável pela coordenação técnica do Fundo, mobilizando diferentes tipos de capitais, conforme a natureza da interação que cada um estabelece no campo.

Todos os agentes que integram o Comitê Programático contribuem no processo seletivo dos empreendimentos que serão apoiados pelo Fundo, mobilizando capital técnico-operacional e capital intelectual, ou seja, metodologia e know-how que fundamentam a interação entre o Fundo e os empreendimentos locais. Esses agentes são responsáveis pela elaboração do edital e dos critérios de seleção para os negócios, pela análise e escolha dos projetos a serem apoiados, e posteriores acompanhamento e monitoramento. Além disso, a Câmara de Animação Econômica da Prefeitura de São Miguel contribuiu especialmente na fase preparatória do processo seletivo com um mapeamento dos grupos produtivos da região, identificando potencialidades e necessidades e colaborando com a adequação do edital à realidade local. Posteriormente, passou a oferecer acompanhamento direto e orientação aos empreendimentos apoiados na primeira edição do Fundo.

Vincula-se ao Comitê Programático um Comitê de Monitoramento e Avaliação, instância responsável pela capacitação dos empreendedores selecionados e pelo acompanhamento e avaliação dos seus projetos. Este comitê mobiliza capital técnico-operacional na interação direta com os empreendimentos apoiados pelo fundo, ou seja, aporta capacidade técnica e participa da execução de ações voltadas para o aprimoramento dos negócios apoiados pelo Fundo. Na primeira edição do Fundo, compunham esta instância a UNICSUL que, por meio

\footnotetext{
${ }^{12}$ Na segunda edição, cujo edital foi lançado em 2011, o SENAC São Paulo passou a integrar o Comitê Programático.
} 
de sua Empresa Júnior, forneceu orientação aos empreendedores nas áreas de economia e finanças, além da cessão de espaço para reuniões dos Comitês do Fundo e para as capacitações; o SEBRAE-SP, que realizou capacitações em diversos temas de gestão, marketing e comercialização; e a Fundação Tide Setúbal, que abrigou institucionalmente a equipe técnica de apoio e acompanhamento dos projetos, além de compor a Secretaria Executiva do Fundo. Tendo em vista o monitoramento financeiro dos projetos, a FUNDEP capacitou os empreendedores em compras e prestação de contas.

A Fundação Tide Setúbal, na condição de idealizadora e patrona do Fundo Zona Leste Sustentável, adicionalmente mobilizou diferentes capitais. A aplicação da metodologia e do know-how que fundamentam a idealização e a concepção do Fundo envolveu a mobilização de capital intelectual. O capital técnico-operacional da Fundação, ou seja, sua capacidade técnica e de execução, foi mobilizado na constituição das instâncias que estruturalmente compõem o Fundo, incluindo a identificação e a mobilização dos agentes locais. E o capital financeiro - o aporte de recursos para a primeira edição do Fundo - foi mobilizado em grande medida pela própria Fundação. A Fundação Votorantim também contribuiu com recursos para a primeira edição do Fundo, aportando capital financeiro, sem vincular-se formalmente às instâncias de gestão.

A interação entre o Fundo Zona Leste Sustentável e os empreendimentos por ele apoiados ocorre por meio dos agentes que compõem o Comitê de Monitoramento e Avaliação e a Secretaria Executiva do Fundo. Nesta interação, é mobilizado capital técnico-operacional, como já descrito, e também ocorre uma segunda mobilização de capital financeiro - o investimento monetário feito pelo Fundo nos projetos de aperfeiçoamento dos negócios. Esses projetos compreendem a aquisição de equipamentos e matéria-prima, de acordo com um plano de negócios aprovado pela Secretaria Executiva do Fundo.

Uma das premissas do Fundo é criar e fortalecer cadeias de valor entre os empreendimentos apoiados. Nesta interação, capital humano é mobilizado, sob a forma de um conjunto de capacidades que permitem às pessoas desenvolverem seus potenciais, aproveitarem oportunidades e realizarem ações conjuntas e integradas no campo. Esse capital humano é oriundo da ação e da iniciativa dos próprios empreendedores, os quais buscam divulgar e apoiar solidariamente uns aos outros. Essa interação também prevê mobilização de capital 
operacional, como na capacidade de institucionalmente apoiar ações no campo; isso é exemplificado pela prestação de serviços entre os empreendimentos apoiados pelo fundo, como a separação e o envio de materiais para cooperativas de reciclagem, ou a oferta de assessoria contábil a preços reduzidos.

$\mathrm{Na}$ interação com o Fundo Zona Leste Sustentável, os empreendimentos apoiados desempenham importante papel na sua divulgação local e legitimação. Para isso mobilizam capital humano em suas redes de relações a fim de que mais empreendedores se beneficiem da iniciativa, desenvolvendo seus potenciais, aproveitando oportunidades e realizando ações conjuntas e integradas no campo.

Para a realização de negócios, os empreendimentos estabelecem relações comerciais com diversos agentes no campo, como clientes, fornecedores e parceiros. Essas cadeias produtivas geralmente incluem importantes interações com pessoas físicas - vizinhos, amigos e familiares que trabalham na própria organização, auxiliam na divulgação "boca-a-boca" e oferecem diferentes tipos de apoio. De acordo com a natureza do negócio de cada empreendimento apoiado, essas cadeias incluem também diferentes tipos de clientes, fornecedores e parceiros comerciais. Tais interações ocorrem por meio da mobilização de capital operacional, ou seja, a capacidade que cada elo da cadeia tem para apoiar institucionalmente a execução de ações no campo.

Ainda sob o ponto de vista do espaço ocupado pelos empreendimentos no campo, observou-se interações mais complexas estabelecidas por um dos empreendimentos participantes deste estudo, o qual apresenta características bastante distintivas dos demais: trata-se de um negócio social voltado para a capacitação em costura e para a produção de bolsas com materiais reciclados. Este negócio é parte de um empreendimento social existente há mais de dez anos em uma comunidade do distrito de São Miguel, o qual desenvolve projetos sociais, culturais e educacionais de geração de trabalho e renda, cidadania, empreendedorismo, sustentabilidade e meio ambiente, atendendo mensalmente 530 crianças, adolescentes e adultos. O empreendimento que abriga o negócio social mantém interações com diversos agentes no campo, fruto de parcerias e articulações construídas ao longo do tempo para a execução de suas ações, como ONGs, lideranças comunitárias, voluntários e fundações, por exemplo, a própria Fundação Tide Setúbal. E o negócio social apoiado pelo Fundo Zona Leste Sustentável se beneficia direta ou indiretamente dessas interações, as quais mobilizam capital 
financeiro, humano, técnico-operacional e intelectual. Com foco no negócio social, o empreendimento acaba de desenvolver um projeto em parceria com a Aliança Empreendedora, a qual também é objeto deste estudo. Segundo o empreendedor desta iniciativa, ao oferecer capacitação em estratégia e gestão, a parceria complementou o aporte financeiro concedido pelo Fundo, fortalecendo o planejamento e a gestão do negócio e seus recursos.

\subsubsection{Disposições do campo}

O Fundo Zona Leste Sustentável fundamenta-se em uma concepção de desenvolvimento local que influencia a ação dos agentes no campo:

Entendemos desenvolvimento como um processo pelo qual a riqueza socialmente gerada e as relações sociais estão orientadas para a satisfação das necessidades pessoais, realização e expansão das suas potencialidades e ampliação das suas liberdades. (FUNDAÇÃO TIDE SETUBAL; GIFE, 2010)

Essa concepção origina um conjunto de disposições inerentes ao próprio funcionamento do Fundo, ou seja, um conhecimento tácito que determina ações e percepções dos agentes ao integrar experiências passadas e impor regularidades ao funcionamento do campo, conforme acepção de Bourdieu (MICELI, 2007; MISOCZKY, 2003).

Embora tenha sido concebido, criado e implantado pelas mãos da Fundação Tide Setúbal, o Fundo está assentado sobre uma concepção de desenvolvimento como um processo de construção coletiva, tendo a comunidade como seu grande agente transformador.

Comunidade entendida não como um grupo específico de pessoas em situação de vulnerabilidade social, mas, antes, como um conjunto de atores com interesses mútuos que convivem num mesmo território e cujas ações impactam diretamente no seu cotidiano.(Ibid.)

Sobre estes pilares, sustenta-se a premissa de que o sucesso nos processos de desenvolvimento local é obtido pelo diálogo constante e a construção de parcerias efetivas entre diferentes atores, estabelecendo novos padrões de governança territorial. Assim, a participação no Fundo pressupõe que as pessoas e instituições estejam dispostas a incorporar 
novas condutas em seu modus operandi, pautadas em uma perspectiva sistêmica, passando a considerar o todo em suas opções de vida.

Do ponto de vista do território, observa-se que a economia da região tem grande potencial para gerar desenvolvimento local, mas a forma como as cadeias de valor estão constituídas não favorece tal processo. Os impostos recolhidos não são investidos na região, a oferta de empregos é escassa, as empresas não identificam ou não optam por fornecedores locais. Nesse contexto, o Fundo Zona Leste Sustentável emerge como uma experimentação com aproveitamento do potencial econômico da região. Seus criadores calculam que a estruturação do Fundo e seus impactos mais evidentes no campo demandam em torno de uma década para se consolidar.

A vivência prática da Fundação Tide Setúbal e demais parceiros do Fundo na região mostrou a necessidade de ações que representem um passo além da proteção social. No contato com as carências e necessidades da comunidade e de suas parcelas mais vulneráveis, essas organizações identificaram a presença de grupos criativos com grande potencial empreendedor, que dificilmente se desenvolveriam sem um capital mínimo para tornar seu empreendimento viável e, com isso, gerar postos de trabalho e renda para essa população. Assim, o Fundo se propõe a ser um passo anterior ao microcrédito tradicionalmente oferecido pelos bancos. Para isso, sua interação com os empreendedores locais não se limita ao repasse de recursos financeiros; ela envolve orientação e incentivo para que os negócios sejam formalizados, seus empreendedores capacitados e seus planos de negócios aperfeiçoados, de modo que futuramente esses empreendimentos tenham condições de ingressar no sistema financeiro tradicional.

Além de constituir uma ponte entre os negócios locais e as possibilidades de financiamento, o processo de orientação e capacitação dos empreendedores apoiados pelo Fundo, associado ao monitoramento do projeto e do uso dos recursos, é responsável pelo estabelecimento de novas disposições no campo. Essa mudança na conformação altera regularidades anteriormente inscritas, como a aceitação da atividade produtiva informal e a exacerbação dos limites impostos pela falta de conhecimento em gestão de negócios. As disposições alteradas ou constituídas na interação entre os empreendedores e o Fundo dizem respeito à formalização dos negócios, ao acesso a informação e formação em empreendedorismo e gestão, ao estabelecimento de planos de negócios orientados para estratégias de crescimento e 
consolidação, à identificação de oportunidades locais para compra e venda de produtos e serviços, e à instauração de cadeias de valor com impacto local. Nesse sentido, são referências entre os entrevistados a capacitação oferecida pelo SEBRAE e a formalização dos negócios que é feita com apoio de um escritório de contabilidade - um dos empreendimentos apoiados pelo Fundo. Apesar de gerar resistências entre muitos empreendedores, a nova forma dá origem a condutas que passam a ser valorizadas e geram um novo posicionamento desses agentes no campo, conferindo mais poder individual e potencializando a articulação local.

A criação de uma instituição de base territorial, organizada e gerenciada a partir de ativos, pessoas e organizações locais - um dos princípios que fundamentam a constituição do Fundo Zona Leste Sustentável - também exerce importante influência na alteração de algumas disposições no campo. Por um lado, ela influencia a forma como os empreendedores estabelecem relações entre si e com outros agentes locais. De outro lado, provoca mudanças na forma como os agentes detentores de capital econômico, capital técnico e capital político se posicionam no campo.

Com inspiração nos modelos de Fundações Comunitárias praticados no Brasil e em diversos países, o Fundo tem entre suas aspirações a distribuição da riqueza local por meio de vínculos de mobilização territorial, articulando ações dos atores locais. Pragmaticamente, isso significa fomentar a geração de ação produtiva e de emprego estrutural por meio de relações comerciais e cadeias de valor locais. Os empreendimentos apoiados pelo Fundo são incentivados a se apoiar mutuamente e a gerar benefícios para a localidade, como a priorização de moradores para oportunidades de trabalho e de fornecedores locais para aquisição de produtos e serviços, ou a transferência de tecnologia e o compartilhamento de equipamentos adquiridos com recursos do Fundo. Na prática, entretanto, essa contrapartida sugerida tem sido de difícil aplicação pelos empreendimentos, pois implica na mudança de uma cultura individualista inerente à visão de sobrevivência desses empreendedores em mercados competitivos.

Do ponto de vista estrutural, o Fundo Zona Leste Sustentável é composto por diferentes setores da comunidade. Uma vez apropriado por esse grupo, espera-se que o apoio financeiro e técnico-operacional a empreendimentos locais deixe de depender de terceiros, seja na forma de recursos privados ou de favores políticos. Esse posicionamento no campo é importante, 
pois tradicionalmente, a população da região abrangida pelo Fundo está imersa em uma cultura político-partidária clientelista. A criação de disposições que fortaleçam a capacidade da sociedade civil de se organizar e engendrar redes de colaboração tende a mudar a forma como os empreendimentos locais se relacionam e se posicionam frente aos políticos da região, e frente a outros atores detentores de poder econômico ou intelectual.

Para que os diferentes setores da comunidade sintam-se motivados a participar ativamente do Fundo, busca-se a convergência de interesses entre atuais e potenciais parceiros. Aí reside o desafio de articular a ação de diversos agentes, que mobilizam diferentes tipos de capital, mantendo a personalidade dos parceiros e valorizando as muitas formas de participação. Novas disposições são criadas no campo, na medida em que organizações e instituições participantes do Fundo passam a desenvolver formas de interação entre si, com os empreendimentos apoiados e com os atores que influenciam a posição dos agentes no campo. A própria Fundação Tide Setúbal, principal mentora do Fundo, coloca-se neste campo de uma forma diferente da habitual - reconhecida como protagonista de ações sociais na região, buscou criar bases para que o Fundo seja, de fato, comunitário e gerido por seus componentes. Assim, desde o início, toda a gestão financeira é feita por um dos parceiros que compõem o Fundo, desvinculando-o de outros projetos gerenciados pela Fundação e criando mecanismos de governança local pela atribuição de papéis aos demais agentes que participam da iniciativa.

As trajetórias dos empreendedores apoiados pelo Fundo Zona Leste Sustentável também influenciam a forma como se posicionam no campo, criando algumas disposições comuns e outras disposições diferenciadas entre eles.

A vontade de constituir um negócio próprio, identificando oportunidades no mercado local e mobilizando os recursos necessários para a ação é uma característica comum aos empreendedores entrevistados, assim como a perspectiva de dar continuidade aos negócios já criados, ampliando a oferta de produtos ou serviços, aumentando a escala e a carteira de clientes. Essas características dizem respeito a um conjunto de disposições que orientam a ação dos empreendedores no campo, posicionando-os como agentes que buscam, por meio da mobilização de capital técnico-operacional e capital humano, criar alternativas para geração de renda individual/familiar. Em grande parte, o acesso aos recursos do Fundo Zona Leste Sustentável deve-se a este tipo de "capital empreendedor" inerente aos negócios selecionados pelo Fundo. 
As motivações para constituir um negócio próprio variam entre os empreendedores estudados e se organizam em três grupos, com diferentes impactos nas disposições que orientam a ação destes agentes no campo:

Um tipo de motivação para empreender é a necessidade de ter um trabalho e gerar renda para o sustento da família. Geralmente sem formação técnica certificada ou experiência profissional que habilite esse grupo de empreendedores a ingressar no mercado de trabalho formal, a criação e a venda de produtos ou serviços foi identificada como alternativa de sobrevivência. Ao colocar no mercado local produtos de qualidade e diferenciados - como moda íntima e tapioca - estes empreendedores criaram e fidelizaram uma clientela que lhes permitiu atingir seus objetivos iniciais de geração de renda, melhorar as condições de produção e comercialização, e inovar em produtos. Sua conduta no campo é bastante individualista, ainda centrada na subsistência e na crença de que cabe ao empreendedor toda a força de trabalho, sem a necessidade de ampliar o quadro de empregados ou trazer outras contribuições para a comunidade.

Um segundo grupo de empreendedores tem sua motivação centrada na ambição de abrir um negócio no qual possam utilizar conhecimentos e experiências profissionais anteriores em benefício próprio e, de diferentes formas, em benefício da comunidade. São pessoas que, após anos de experiência em uma ou mais carreiras profissionais, acumularam recursos financeiros e competências que lhes permitem fomentar a criação e o desenvolvimento de um novo negócio - como um escritório de contabilidade ou um espaço cultural-gastronômico. Buscando inovar em seus campos de atuação, esses empreendimentos encontram-se em diferentes estágios de desenvolvimento, mas caracterizam-se pela gestão compartilhada por meio de sociedades e pela abertura para criar oportunidades de trabalho local, seja através da contratação de empregados e serviços, seja através do apoio à comercialização e à divulgação de produtos.

Um terceiro tipo de empreendimento tem o objetivo de proporcionar geração de valor econômico e valor social a uma comunidade em situação de vulnerabilidade social. Movido pela crença na predestinação, pela fé em Deus e por uma visão de trabalho como valor, este empreendedor tem na produção e comercialização de bolsas um meio de capacitação 
profissional para jovens e mulheres que se encontram à margem do mercado de trabalho formal. Os benefícios gerados pelo empreendimento - um negócio social - são integralmente revertidos para os alunos e empregados, bem como para a comunidade, que participa de outros projetos e frentes de proteção social mantidos pelo empreendedor. O posicionamento do empreendimento no campo é, portanto, determinado por disposições que colocam a perspectiva coletiva - na ação e na interação com outros agentes - acima da ambição individual. Assim, a participação no Fundo Zona Leste Sustentável potencializa o impacto do valor gerado localmente.

\subsubsection{Contribuições do Empreendimento Social}

O Fundo Zona Leste Sustentável foi criado com a missão de canalizar recursos de pessoas físicas e jurídicas com interesse em contribuir para a região, e aplicá-los de forma monitorada em iniciativas produtivas locais, permitindo que elas atinjam competitividade no mercado e gerem oportunidades duradouras de trabalho e renda no território. Sua concepção de desenvolvimento local se assenta sobre a premissa de captar e investir recursos em projetos que possam gerar opções de trabalho e renda socialmente mais justas e ambientalmente sustentáveis nos distritos de São Miguel Paulista, Ermelino Matarazzo e Itaim Paulista ${ }^{13}$. Essas regiões contam com economia própria, um setor de comércio ativo e pequenos empreendimentos produtivos que surgiram de maneira espontânea e informal. O Fundo objetiva revigorar essa energia produtiva, com organização, formação de parcerias, capacitação e investimento financeiro.

A premissa que orienta o funcionamento do Fundo é a articulação local priorizando a aplicação de recursos em iniciativas que resultem em interação, complementaridade e aprendizagem, favorecendo o surgimento de redes de cooperação entre empreendedores e o desenvolvimento de cadeias produtivas locais. Dessa forma, o Fundo pretende funcionar como uma espécie de seed money que visa fomentar a rearticulação local e a criação de uma competitividade sistêmica. Em sua primeira edição, a qual foi objeto deste estudo, a criação de arranjos locais não foi efetivada, assim como a expectativa de fortalecer o eixo ambiental da ação. Mas, dada a complexidade desta proposta e seu caráter inovador na região, acredita-

\footnotetext{
${ }^{13}$ A segunda edição do Fundo, cujo edital foi lançado em 2011, contemplou também o distrito de Itaquera.
} 
se que estes são resultados que o Fundo terá condições de obter em médio e longo prazo. Sua primeira edição serviu, principalmente, para avaliar a capacidade de atração da iniciativa.

Os critérios de seleção para os empreendimentos a serem apoiados pelo Fundo consideram o potencial de geração de renda e trabalho para moradores da região, além da capacidade de firmar parcerias com outros empreendedores locais, organizações sociais e poder público. Também são considerados a participação de mulheres no negócio, a inclusão de jovens e o compromisso com práticas sustentáveis. Os candidatos devem ter condições de oferecer contrapartida econômica e não econômica. A contrapartida não econômica pode ser realizada pela contratação de mão de obra de moradores e pelo uso de fornecedores locais, além do compromisso de formalização dos empreendimentos informais em até seis meses após o resultado do edital. Na primeira edição do Fundo, as contrapartidas econômicas deveriam contemplar, no mínimo, 30\% do valor total solicitado, o que inclui, por exemplo, despesas com manutenção de instalações, água, energia e aluguel. Os recursos aplicados nos empreendimentos eram concedidos a "fundo perdido", ou seja, não havia devolução de parte ou da totalidade do recurso investido, o que, segundo a criadora do Fundo, ainda refletia "um olhar mais social do que econômico para a iniciativa”. Com isso, nutria-se uma percepção de que o recurso investido nos pequenos negócios apresentava características mais próprias de uma doação, o que influenciava a forma como as regras eram percebidas pelos empreendedores beneficiados na primeira edição do Fundo. Por exemplo, eles não foram plenamente capazes de cumprir com as contrapartidas exigidas no sentido da geração de emprego local e da criação de uma rede de colaboração comercial local. ${ }^{14}$

Quanto ao estabelecimento de parcerias locais para sustentação do Fundo, o desafio principal foi convencer os atores locais a apoiarem a iniciativa. Por ser novidade, um comportamento inicial de retração e receio exigiu da Fundação Tide Setúbal um papel bastante ativo. A legitimidade da Fundação e de sua atuação na região foi um importante ponto de partida nesse sentido. A equipe local funcionou e funciona como animadora, trabalhando a confiança entre os parceiros, a iniciativa e os empreendimentos. A expertise do consultor que desenvolveu o Fundo e sua habilidade para identificar e captar as primeiras articulações locais também são características que ajudaram a criar as parcerias e, atualmente, a ampliar o escopo de

\footnotetext{
14 Já na segunda edição, o edital determinou que os empreendimentos contemplados contribuíssem financeiramente com o Fundo, com uma quantia que represente um percentual do valor recebido como financiamento, o qual variava de $20 \%$ a $80 \%$, conforme o tipo de empreendimento e a modalidade de projeto.
} 
envolvimento destes parceiros. Para isso, ele detém toda a concepção estratégica do Fundo e é seu representante local do ponto de vista das relações institucionais.

Uma vez construídas as primeiras parcerias, o Fundo adquiriu condições de operar com legitimidade na região. Havia recursos financeiros; um gestor desses recursos que daria garantia de transparência ao processo financeiro; um Comitê Programático, de caráter deliberativo composto por pessoas e organizações notáveis da própria Zona Leste e outras instituições; e um Comitê de Monitoramento e Avaliação composto por organizações tecnicamente reconhecidas como o SEBRAE e a própria Fundação Tide Setúbal.

Angariar o apoio dos primeiros parceiros foi o passo fundamental para realização da primeira edição do Fundo. Entretanto, a expectativa da Fundação Tide Setúbal e da equipe que trabalha para o Fundo é que esse apoio adquira maiores proporções. Espera-se que os seus membros tenham atuação mais efetiva em ações junto aos empreendedores locais e ao próprio Fundo, indo além de uma forma de participação inicial que fora bastante limitada à presença e à contribuição em reuniões do Comitê. $\mathrm{O}$ monitoramento e o acompanhamento dos empreendimentos em campo, por exemplo, é uma forma de participação ativa que complementaria a ação diária da equipe, ampliando os horizontes de possíveis colaborações e a identificação de pontos de atenção na execução do Fundo. O desenho e a aplicação de programas e capacitações mais customizados para as necessidades dos empreendimentos é outra forma de ação potencial para as organizações-membros do Fundo.

Como o Fundo ainda não conta com infraestrutura própria e independente, a Fundação Tide Setúbal continua responsável pela sua sustentação em determinadas situações, como a elaboração de relatórios e ações de comunicação. Também o primeiro aporte de recursos foi feito pela Fundação, com contribuição do Instituto Votorantim e outras doações captadas pela Fundação e sua Presidente. Um grande desafio que se coloca, neste cenário, é a criação de uma estrutura própria para o Fundo, constituído como pessoa jurídica autônoma, com participação ativa de seus membros. Um segundo desafio é a captação de recursos locais para sustentação do Fundo, a qual representa o seu enraizamento no território e a ampliação de sua capacidade de financiamento de projetos, em termos quantitativos e qualitativos. Superados esses desafios, acredita-se que o Fundo poderá se tornar referência, um modelo de desenvolvimento local. 
Ainda que se consolide como instituição autônoma, não se pode esperar que o Fundo seja, isoladamente, responsável pela melhoria dos indicadores de desenvolvimento local. Sua contribuição agrega a outras iniciativas da região a possibilidade de integrar ações e potencializar resultados, tendo o olhar no fortalecimento da economia local. Essa perspectiva reforça a motivação original para criação do Fundo, que visava complementar outras frentes da Fundação Tide Setúbal, reconhecida protagonista em ações sociais na região, como descrito anteriormente. Segundo sua criadora, um projeto potencializa outro, cada qual com uma metodologia diferente, abordagem diferente, públicos-alvo diferentes, todos orientados para a promoção do desenvolvimento local.

Do ponto de vista dos empreendimentos apoiados, o Fundo aportou dois tipos principais de contribuições: a aquisição de bens e materiais, e a aquisição de conhecimento.

Todos os empreendimentos pesquisados foram beneficiados com recursos do Fundo para aquisição de bens necessários para ampliar escala ou diversificar produtos e serviços, tais como computadores, máquinas de costura e equipamentos de cozinha, além de matéria-prima. Os empreendimentos que participaram deste estudo foram contemplados com:

Tabela 4 - Itens financiados pelo Fundo para os empreendimentos entrevistados

\begin{tabular}{|l|l|}
\hline \multicolumn{1}{|c|}{ EMPREENDIMENTO } & \multicolumn{1}{|c|}{ ITENS FINANCIADOS } \\
\hline Escritório de contabilidade & Computador, armário, pontos de rede e ações de marketing \\
\hline Espaço cultural-gastronômico & $\begin{array}{l}\text { Fogão, freezer, geladeira, liquidificador, processador, batedeira, utensílios } \\
\text { como espremedor e balança, louça, notebook, confecção de site; } \\
\text { formalização do empreendimento, materiais de comunicação visual. }\end{array}$ \\
\hline Confecção de moda íntima & Máquina de costura, matéria-prima e curso de moda. \\
\hline Loja de tapioca & Equipamentos para produção: freezer, misturela para preparação de massa. \\
\hline Confecção de bolsas & $\begin{array}{l}\text { Máquinas de costura, material de comunicação visual, porta para área de } \\
\text { produção do empreendimento. }\end{array}$ \\
\hline
\end{tabular}

A capacitação oferecida pelo SEBRAE é outra contribuição ressaltada pelos empreendimentos pesquisados. Concretamente, além da capacitação em si, a participação nos cursos permitiu o contato com outros empreendedores e o compartilhamento de dúvidas e aprendizados. A assessoria prestada pela equipe do Fundo complementa a capacitação técnica, 
conscientizando os empreendedores sobre a necessidade de formalização, gestão e sustentabilidade. Segundo uma entrevistada, sem esses apoios é muito difícil empreender, pois há coisas muito difíceis de obter individualmente.

Por fim, a rede constituída entre os empreendimentos, com maiores e menores graus de colaboração, é reconhecida como uma contribuição trazida pelo Fundo, ainda que muito mais pautada na criação de laços de vizinhança do que em vínculos de negócios.

\subsubsection{Resultados para o desenvolvimento social}

A missão do Fundo Zona Leste Sustentável preconiza o fomento de iniciativas de produção local para que se tornem competitivas no mercado e gerem oportunidades duradouras de trabalho e renda no território (Fundo Zona Leste Sustentável, Relatório de Atividades 20102011). Insere-se, portanto, em uma perspectiva de desenvolvimento voltada para a expansão de liberdades econômicas, conforme acepção de Sen (2000), ou seja, o acesso das pessoas a oportunidades de utilização de recursos econômicos para consumo, produção ou troca. A orientação estratégica do Fundo está ainda mais fortemente alinhada às proposições de Sachs (2004) quanto à centralidade do direito ao trabalho e ao empreendedorismo como meios para a maximização de oportunidades que habilitem as pessoas para o exercício de seus direitos.

O Fundo, entretanto, não ambiciona contribuir de forma exclusiva para a promoção do desenvolvimento local na região onde opera. Elucidado por Sen $(2000,2007,2008)$ e Sachs (2004), o desenvolvimento implica no acesso a diferentes dimensões de inclusão social ou liberdades instrumentais. Ou, como observa Kliksberg (1997, 2003), o desenvolvimento social é promovido em condições nas quais o investimento em competitividade e tecnologia é acompanhado por investimentos em campos como educação, saúde e nutrição. Aplicado em nível local, suas premissas alinham-se ao papel complementar e integrador que o Fundo se propõe a desempenhar com vistas ao desenvolvimento social na região. Ele agrega o componente econômico do desenvolvimento aos programas já existentes em educação, cultura, saúde e políticas públicas, muitos realizados por iniciativa da própria sociedade civil em Fóruns locais, e outros realizados diretamente pela Fundação Tide Setúbal.

Quanto à complementaridade entre os objetivos do Fundo e as ações realizadas pela Fundação, observa-se que distintas esferas de desenvolvimento são trabalhadas. Mudanças na 
esfera da riqueza material são promovidas no fomento ao empreendedorismo, geração de renda e trabalho via Fundo, como será detalhado a seguir. Na esfera do bem-estar social, mudanças são obtidas pelo acesso a atividades em comunicação, música, teatro, esportes, cultura, temáticas da juventude e melhoria da qualidade de vida, tendo como público crianças, jovens e adultos da região de São Miguel Paulista. Essas atividades acontecem em espaços públicos, gerenciados pela Fundação: o Clube da Comunidade Tide Setubal (CDC), em parceria com a Secretaria Municipal de Esportes, Recreação e Lazer (Seme) e o Galpão de Cultura e Cidadania, em parceria com a Sociedade Amigos do Jardim Lapenna, organização local. Na esfera do empoderamento, a Fundação Tide Setúbal cria e mantém espaços de referência comunitária, ação direta com o público-alvo; formação de agentes locais; e ações de fortalecimento institucional da região, por meio das parcerias, levando em conta as múltiplas dimensões que caracterizam o desenvolvimento local (economia, cultura, educação, saúde, política, sustentabilidade ambiental). Além disso, cria fóruns para o diálogo e para a reflexão, estimulando o encontro entre moradores, lideranças comunitárias, organizações da sociedade civil, poder público e iniciativa privada. Busca também conectar as demandas do bairro às políticas públicas, colocando as questões da cidade no mapa de São Miguel Paulista e unindo a região ao centro da cidade.

Promover impactos locais em termos de desenvolvimento econômico-social no território é uma perspectiva de longo prazo para o Fundo, como já discutido. Os resultados pretendidos no curto prazo, por sua vez, mostram-se modestos e adequados ao alcance de uma iniciativa ainda incipiente. As potenciais mudanças desejadas para os empreendedores e empreendimentos apoiados focam a conquista de autonomia na condução dos negócios e no fomento ao protagonismo destes atores. Tal perspectiva coloca o Fundo como uma alternativa coletiva de ação que visa ajudar os empreendedores a perceberem que não precisam temer a burocracia ou depender de favores de representantes políticos locais. E, mais do que isso, coloca o Fundo como uma forma inovadora de financiamento, com foco no desenvolvimento local por meio da valorização de fornecedores e mão de obra local. Por conseguinte, num segundo patamar de mudanças almejadas no curto prazo, encontra-se a criação de postos de trabalho. 
As mudanças de curto prazo, previstas no nível da capacidade individual dos empreendimentos, foram visíveis na primeira edição do Fundo, conforme relatos da equipe que conduz o projeto e observação de uma amostra de empreendimentos apoiados.

O acesso a oportunidades de negócio é o principal indicador de mudanças proporcionadas pelo Fundo na esfera da riqueza material. Alguns empreendimentos operavam em condições bastante precárias, usando instalações improvisadas nas residências de seus criadores e contando com trabalho de natureza familiar e informal. Para esses negócios, a formalização e a criação de melhores condições físicas de trabalho incentivadas pelo Fundo resultaram em mudanças significativas na profissionalização dos empreendimentos.

Com a possibilidade de emitir nota fiscal para a realização de transações, o acesso a lojas e outros clientes de porte foi facilitado. Vislumbrando este horizonte, a confecção de moda íntima ampliou o portfólio de produtos e pretende contratar uma auxiliar. Além disso, a empreendedora objetiva aumentar o volume de "sacoleiras", ou seja, de pessoas que vendem seu produto no sistema "porta-a-porta", reconhecendo que esta forma de trabalho dá oportunidade de geração de renda para mulheres sem condições de ingressar no mercado de trabalho formal.

Algumas contratações de mão de obra também já foram verificadas nos empreendimentos, ainda que com baixa intensidade, ampliando a capacidade de atendimento da demanda por produtos e serviços. O escritório de contabilidade contratou três funcionários após receber o aporte do Fundo. Além disso, adquiriu fôlego financeiro para investir o próprio capital de giro.

A participação em programas estruturados de formação profissional e o apoio financeiro para aquisição de maquinários resultaram na ampliação da gama de produtos e serviços em muitos dos empreendimentos. O mesmo escritório de contabilidade avalia que a entrada de equipamentos mais modernos, custeados pelo Fundo, contribuiu para a eficiência no atendimento ao cliente, sabendo que este é um diferencial buscado no mercado em que atua. O ganho em eficiência foi potencializado com o investimento de recursos do Fundo em internet e marketing. $\mathrm{O}$ empreendedor estima que a carteira de clientes aumentou trinta por cento após o investimento do Fundo. 
Os recursos, capacitações e orientações proporcionados pelo Fundo viabilizaram à pequena loja de artesanato o estabelecimento de uma nova abordagem para o negócio, com foco em gastronomia. Sem perder a característica de aconchego propiciada pelo modelo de negócio desenhado, o empreendimento tornou-se um diferenciado espaço cultural-gastronômico, cuja procura muitas vezes gera lista de espera. Já para a loja de tapiocas, a capacitação e o apoio financeiro foram potencializados com a divulgação do negócio na grande mídia, o que gerou um aumento estimado de $20 \%$ no faturamento. O empreendimento que oferece capacitação em costura e produz bolsas por meio da reciclagem de materiais avalia como principal mudança o aumento na quantidade de pessoas capacitadas e o incremento na geração de renda, por meio da cooperativa. Com cinco máquinas, capacitava dez pessoas em cada curso; com mais dez máquinas adquiridas por meio do Fundo, passou a capacitar 40.

O acesso a crédito bancário e a linhas de investimento também se tornou mais viável para os empreendimentos apoiados, seja pela formalização do negócio, seja pelo aval que a participação no Fundo lhes confere, como observa a empreendedora do espaço culturalgastronômico. Mas são raros os empreendimentos que buscaram ou estão buscando esse tipo de recurso; a grande maioria, ainda receosa, prefere investir recursos próprios provenientes do capital de giro.

Os resultados obtidos pelos negócios a partir do apoio dado pelo Fundo Zona Leste Sustentável ocasionaram importantes mudanças na esfera individual de riqueza material. Para um dos empreendedores, cujo negócio já vinha em ritmo acelerado de crescimento, a perspectiva de ampliação da base de clientes assegurada com os recursos investidos pelo Fundo possibilitou a aquisição de um veículo, a finalização da reforma de sua residência e o planejamento do casamento. Para os empreendedores que ainda experimentavam fases mais incipientes de desenvolvimento dos negócios, os resultados obtidos com o apoio do Fundo propiciaram aumento da renda familiar, com a consequente melhoria no padrão de vida e a quitação de dívidas particulares. De forma menos tangível, uma empreendedora observa que ainda não obteve o padrão financeiro que deseja com o empreendimento, mas valoriza os ganhos que tem obtido em termos de realização pessoal. 
Mudanças na esfera do bem-estar social não foram observadas entre os empreendedores apoiados pelo Fundo que participaram deste estudo. Esses já desfrutavam de condições adequadas de acesso a saúde, educação e moradia, por exemplo.

Mudanças na esfera do empoderamento, seja do ponto de vista dos empreendedores, seja do ponto de vista da comunidade, também não foram observadas neste estudo. Possíveis mudanças, como o fortalecimento da participação comunitária e a ampliação do acesso a programas e equipamentos públicos, por exemplo, não figuram entre as prioridades apontadas pelos empreendedores entrevistados. Como já discutido, a maior parte dessas pessoas apresenta atitudes individualistas e luta pela sobrevivência de seu negócio com elevadas cargas horárias de trabalho, fatores que reduzem o tempo disponível e a importância atribuída a atividades que levem ao fortalecimento do capital social e do capital político local. Além disso, há que se considerar que as mudanças em indicadores de empoderamento não eram buscadas diretamente pelo Fundo Zona Leste Sustentável, cujos objetivos são claramente orientados para o fortalecimento da economia local pela criação de cadeias produtivas, geração de renda e de empregos.

Novamente, entre os negócios estudados, são observados como exceção os resultados do empreendimento social que é apoiado pelo Fundo. Neste caso, a amplitude e impacto das mudanças percebidas na comunidade local são influenciados pela natureza social do empreendimento e pela busca de parcerias que agreguem valor em diferentes frentes, com maior articulação institucional e foco orientado para o desenvolvimento local. A capacitação profissional oferecida pela organização gera mudanças na esfera do bem-estar social, ao melhorar as condições individuais de acesso a trabalho e renda. A oferta de programas educacionais, culturais e esportivos a crianças e jovens da comunidade contribui para o fortalecimento do capital social local, suprindo lacunas deixadas pelo Estado em termos de serviços e equipamentos.

Em resumo, o Fundo Zona Leste Sustentável tem contribuído para a melhoria de indicadores de desenvolvimento na esfera da riqueza material, seja do ponto de vista do fortalecimento dos negócios apoiados, seja do ponto de vista da distribuição de riqueza entre os empreendedores. A melhoria de indicadores nas esferas do bem-estar social e empoderamento, embora não verificada neste estudo, pode vir a ocorrer na medida em que a comunidade local, inclusive os empreendedores apoiados pelo Fundo, beneficiem-se de 
programas e ações complementares à ação econômica. Esse processo envolve a integração de ações entre o Fundo e os demais programas de proteção e desenvolvimento social existentes no território.

\subsubsection{Interação e Comunidade dos Portais}

Este caso descreve a ação do empreendimento social Interação com o objetivo de promover o desenvolvimento social em âmbito local na Comunidade dos Portais, em Osasco, na Grande São Paulo. Por meio da aplicação de uma metodologia testada e implantada com sucesso em 35 países pelo Slum Dwellers International, o empreendimento social visa fomentar a mobilização comunitária, o acesso a melhores condições de habitação e a transformação social local. A Comunidade dos Portais, composta por 600 famílias que viviam em condições precárias de moradia, foi a primeira experiência da Interação na aplicação da metodologia no Brasil.

Inicialmente, este capítulo descreve o contexto em que se situa o caso estudado, circunscrevendo o campo no qual diferentes agentes interagem e influenciam a ação realizada pela Interação junto à Comunidade dos Portais. Os meios pelos quais o empreendimento social reúne contribuições na iniciativa estudada são descritos a seguir. Por fim, são identificados e analisados os resultados obtidos na promoção do desenvolvimento social em âmbito local.

\subsubsection{O Campo: agentes e capitais}

A Rede Internacional de Ação Comunitária - Interação é um empreendimento social estabelecido como associação sem fins lucrativos, fundado em dezembro de 2004 em São Paulo. É representante do SDI - Slum Dwellers International, uma rede que integra comunidades e organizações voltadas para ações no campo da habitação em 35 países da África, Ásia e América Latina. A Interação desenvolve atividades junto a moradores de favelas, cortiços e outros assentamentos precários no Brasil, oferecendo suporte técnico-social para que eles estabeleçam e conquistem metas de desenvolvimento a partir de iniciativas que garantam melhoria das condições de habitação, educação financeira, geração de renda, preservação ambiental e cidadania. Seus objetivos são: 
- Garantir a promoção do desenvolvimento econômico, social e combate à pobreza;

- Garantir a promoção da ética, paz, cidadania, direitos humanos, democracia e outros valores universais;

- Estimular e capacitar organizações comunitárias em prol da obtenção da moradia digna e formal, promovendo troca de experiências, ideias, estratégias e recursos;

- Estimular a liderança e o fortalecimento da mulher;

- Implementar a metodologia participativa constituída pelo autorrecenseamento, poupança comunitária e intercâmbio. (Interação, documento institucional)

A Interação desenvolve suas atividades em um campo, ou conforme acepção de Bourdieu, um espaço social formado por uma rede de relações objetivas entre diferentes agentes (BOURDIEU, 1990; MAYORAL BLASCO, 2010). Esses agentes são organizações e instituições parceiras, oriundos de diferentes setores - privado, público e sem fins lucrativos. Cada agente detém um tipo específico de capital, entendido como atributos de poder, cuja mobilização determina as posições relativas que ocupam no campo e o tipo de interação que será estabelecida entre os agentes. (Ibid.,ibid.).Especificamente no campo em que a Interação opera, os agentes mobilizam capital intelectual, capital financeiro e capital técnicooperacional.

Os profissionais que fundaram e que atuam no empreendimento social operam no campo mobilizando capital intelectual, ou seja, são detentores da metodologia e do know-how que fundamentam as ações realizadas no campo onde o empreendimento social se insere. Esse capital intelectual é formado a partir das consistentes trajetórias de seus fundadores nas áreas de habitação e mobilização social, acrescida da multidisciplinaridade das equipes que trabalham nos projetos desenvolvidos pelo empreendimento, e é fortalecido pela parceria estabelecida com o SDI, organização que desenvolveu a metodologia utilizada pela Interação $^{15}$. Essa metodologia foi criada na Índia, em meados da década de 1980, por três organizações indianas: National Slum Dwellers Federation, Mahila Milan e Society for the Promotion of Area Resource Centers (SPARC). O embrião desta metodologia originou-se na

\footnotetext{
${ }^{15}$ Até a realização deste estudo, a metodologia do SDI já havia sido aplicada pela Interação em comunidades dos municípios de Osasco, Várzea Paulista, São Paulo, Suzano, Santos e Sorocaba, no estado de São Paulo, além de comunidades em Olinda, Camaragibe e Recife, no estado de Pernambuco, no município de Novo Gama, em Goiás, e em comunidades de Cochabamba e Oruro, na Bolívia.
} 
estruturação de pensamentos e na experiência de mulheres que, despejadas de suas moradias, uniram-se para criar iniciativas coletivas de transformação de suas realidades naquele país.

O capital intelectual mobilizado pela Interação para empreender ações e projetos junto a comunidades também está presente na participação em redes e grupos ligados à sua área de atuação, como a Associação Brasileira de Cimento Portland. Essa associação constitui um grupo com representantes do governo, entidades de classe, sociedade civil e movimentos sociais que busca alternativas em reforma e assistência técnica no Brasil, como forma de expandir o acesso à moradia.

Diferentes agentes mobilizam capital financeiro na interação com o empreendimento social, ou seja, aportam recursos financeiros de origem pública ou privada para as ações realizadas no campo. O Urban Poor Fund International - UPFI é um fundo gerido pelo SDI, responsável pelo maior aporte de recursos financeiros para as ações de implantação da metodologia pela Interação e para a realização dos intercâmbios entre comunidades. O financiamento de alguns projetos deriva de recursos obtidos por Termos de Parceria firmados com prefeituras locais para a realização de ações de caráter social em projetos habitacionais. A Geração Futuro, corretora de valores, contribui financeiramente com iniciativas de educação financeira para mulheres das comunidades apoiadas pela Interação. Assessorias a clientes públicos ou privados complementam o capital financeiro mobilizado pelo empreendimento social para a realização de suas atividades.

Interações pontuais são estabelecidas com agentes privados, com ou sem fins lucrativos, para ações de fortalecimento institucional do empreendimento e para aporte de recursos financeiros nos projetos. Esses agentes mobilizam capital técnico-operacional, ou seja, a capacidade técnica instalada associada à capacidade de execução de uma ação efetiva no campo. Como exemplos, a $\mathrm{NESsT}^{16}$ fornece apoio para o planejamento estratégico do empreendimento social, e a Interface Filmes apoiou a realização de um vídeo institucional e algumas oficinas de vídeo em uma das comunidades apoiadas pela Interação.

\footnotetext{
${ }^{16}$ O NESsT é uma organização internacional sem fins lucrativos dedicada à solução de problemas sociais de ordem crítica nos países emergentes através do desenvolvimento e do suporte a empreendimentos sociais, com o objetivo de fortalecer as bases da sustentabilidade financeira das organizações da sociedade civil e potencializar ao máximo o seu impacto social. www.nesst.org
} 
As atividades da Interação tiveram início com a implantação da metodologia do SDI na Comunidade dos Portais, favela estabelecida em 2001 na periferia do município de Osasco. Lá residem famílias que foram despejadas de ao menos três favelas (Rochedalle, Menck e Pinheirinho) e transferidas em caráter temporário pela Prefeitura Municipal para uma propriedade privada que recebeu a denominação de Portais. Em 2005, ano de início da parceria com a Interação, a Favela dos Portais tinha 600 famílias, 89\% das quais alojadas em precárias casas de madeira. A renda mensal de 40,39\% dessas famílias não era superior a $\mathrm{R} \$$ 350,00 e ficava entre $\mathrm{R} \$ 350,00$ e $\mathrm{R} \$ 750,00$ para 39,73\% delas. Apenas 9,6\% tinham renda superior a $\mathrm{R} \$ 750,00$. O principal sonho compartilhado pela maioria (73\%) era o da casa própria $^{17}$.

A parceria entre a Interação e a Comunidade dos Portais configura um campo particular, no qual diferentes agentes mobilizam variadas formas de capital e estabelecem relações que determinam o tipo de ação e os resultados obtidos na promoção do desenvolvimento social em âmbito local. A análise da gênese e da dinâmica interna deste campo em particular é feita a seguir.

A participação da Interação no campo, por meio do estabelecimento da parceria com a Comunidade dos Portais, compreendeu três momentos simultâneos de aplicação da metodologia desenvolvida pelo SDI: a criação da poupança comunitária, a execução do autorrecenseamento e a realização de intercâmbios.

A poupança comunitária é tida como a pedra fundamental da estratégia de mobilização da Interação. Constitui um fundo formado e mantido por recursos financeiros dos próprios moradores das comunidades, organizados em grupos de poupança cujo número de participantes é variável, mas limitado a 30 por grupo. Cada grupo tem três tesoureiros da comunidade, responsáveis conjuntamente por realizar as movimentações bancárias de abertura de conta-poupança, depósito dos valores coletados junto aos poupadores da comunidade, resgates de valores (conforme solicitação e aval de cada poupador), monitoramento do investimento e outras providências. Os tesoureiros também são responsáveis pela animação dos grupos de poupança, na condição de espaços de participação: nas reuniões mensais de prestação de contas, são debatidos e encaminhados temas de interesse

\footnotetext{
${ }^{17}$ Segundo levantamento feito pelos próprios moradores, através de autorrecenseamento.
} 
geral da comunidade. Não há valores pré-estipulados ou frequência mandatória para poupar, variando de grupo para grupo. Tanto os tesoureiros quanto os poupadores mantêm cadernos e cadernetas de registro das movimentações efetuadas individualmente, conferindo transparência ao processo. Operando dessa forma, os grupos de poupança são baseados primordialmente em relações de confiança, e o encontro periódico de seus membros fomenta o fortalecimento e a criação de novos vínculos. Mais do que juntar dinheiro, o grupo de poupança visa "juntar gente", "juntar as pessoas", como explica um dos moradores da comunidade dos Portais.

Com a organização proveniente dos grupos, os poupadores passam a antecipar dificuldades e oportunidades, bem como discutir questões de gastos e gestão de recursos, que frequentemente evoluem para assuntos como planejamento, estratégias de atuação e negociações com o poder público, assim como possíveis parceiros. Dessa forma, a poupança torna-se um instrumento de fortalecimento que possibilita aos poupadores negociarem e lutarem por suas demandas. (Interação - documento institucional)

O autorrecenseamento é um censo feito pelos próprios moradores de uma área. Ele inclui informações cadastrais mais comuns, como dados demográficos e perfil socioeconômico, e informações tidas como relevantes pela própria comunidade, como a quantidade de pessoas com necessidades especiais, idosos com dificuldade de locomoção e os sonhos das pessoas. O autorrecenseamento funciona como uma ferramenta de mobilização comunitária, promovendo a aproximação das pessoas, o conhecimento mútuo e a formação de conhecimento coletivo.

Este conhecimento é essencial para o fomento de ações democráticas tanto com o poder público, como com outros agentes. Os moradores têm, dessa forma, a oportunidade de reconhecer e identificar suas necessidades e prioridades, assim como utilizar a informação obtida para se aproximar de representantes públicos e privados para diálogos mais qualificados e negociações melhor instrumentalizadas. (Interação - documento institucional)

Os intercâmbios entre comunidades promovem a troca de informações, experiências e técnicas diretamente entre moradores de diferentes assentamentos precários. Podem ocorrer dentro de uma cidade, entre cidades ou mesmo entre países, contemplando moradores identificados pelo seu perfil de liderança e mobilização, além de atores locais relevantes, como representantes do poder público. Em cada intercâmbio, a delegação formada por técnicos da Interação, membros da comunidade visitante e outros atores convidados 
permanecem por alguns dias na comunidade visitada, conhecendo as dificuldades existentes e as soluções encontradas. A troca de experiências e conhecimentos por meio dos intercâmbios proporciona uma nova compreensão da realidade particular, o reconhecimento de desafios comuns entre assentamentos precários nacional e internacionalmente, e a busca de soluções coletivas, "além de possibilitar a formação de uma rede de ação, que tem um alto poder de fortalecimento das iniciativas particulares de cada comunidade, cidade, estado, região e país." (Interação - documento institucional)

O apoio dado pela Interação à Comunidade dos Portais, por meio deste conjunto de ações, deu-se em um campo composto por múltiplos agentes, como retratado na ilustração 3:

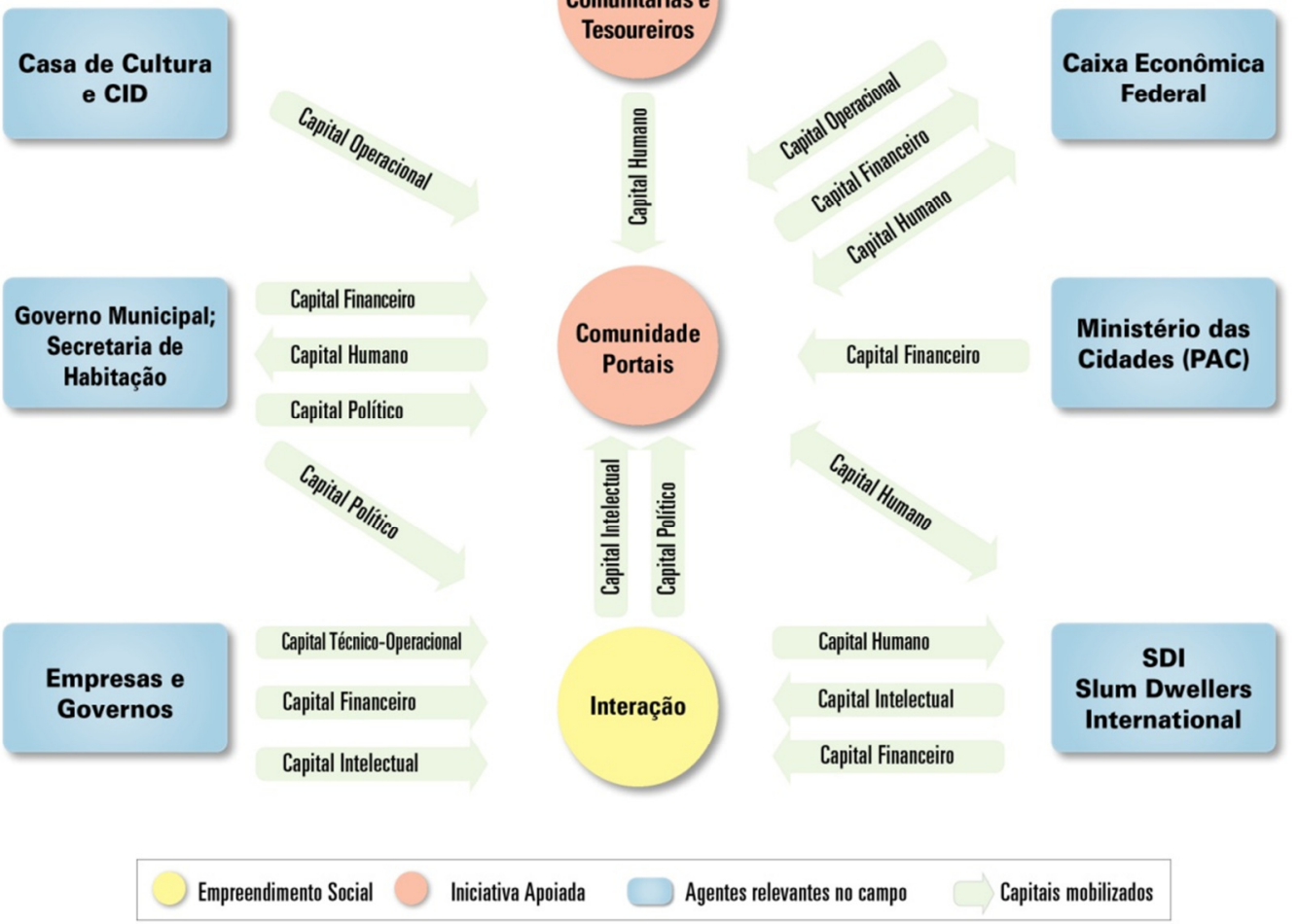

\section{Ilustração 3 - Interações dos Agentes no Campo}

Nesse campo, o empreendimento social mobilizou capital intelectual próprio e aportado pelo SDI, ou seja, metodologia e know-how. Essa interação teve a finalidade de mobilizar o capital humano da comunidade - o conjunto de capacidades que permitem às pessoas desenvolverem seus potenciais, aproveitarem oportunidades e realizarem ações conjuntas e integradas no 
campo. Essa era a condição fundamental para que o principal objetivo do projeto fosse alcançado: a transformação de uma favela instalada de forma irregular num conjunto habitacional de propriedade de seus moradores.

O capital humano da Comunidade dos Portais foi mobilizado, principalmente, com a criação dos grupos de poupança e com a realização dos intercâmbios. Os grupos de poupança uniram as pessoas em torno de um objetivo comum - a urbanização da favela -, e com isso, fortaleceram a atuação organizada para sua própria transformação social. Proporcionados pelo SDI e sua subsidiária UPFI, os intercâmbios ampliam os limites territoriais do campo onde operam a Interação e a Comunidade dos Portais. Ao mobilizar capital humano, esses intercâmbios foram e são importantes para consolidar a identidade comunitária, suas forças e fraquezas, frente a outras realidades. Mas também contribuíram para a constituição de um pequeno núcleo de lideranças, geralmente tesoureiros, que se diferencia dos demais moradores da comunidade por serem constantemente contemplados nessas oportunidades, ainda que isso aparentemente não cause incômodos localmente ${ }^{18}$.

No campo, destaca-se o papel desempenhado pela Prefeitura Municipal de Osasco, sobretudo a Secretaria de Habitação. Foi com apoio e por intermédio deste agente que a Interação chegou à Favela dos Portais e apresentou sua proposta, no ano de 2005. Fundamentais para a construção e a legitimação da iniciativa, as interações entre os três principais agentes do campo- empreendimento social, comunidade e governo - mobilizaram capital político, ou seja, a influência exercida por instituições e sistemas políticos cujos poderes são reconhecidos pelos agentes do campo. Essa interação veio a contribuir decisivamente para a implementação de políticas públicas em habitação, onde a ação exclusivamente estatal se arrastava há anos. Por intermédio da rede de relações dos fundadores da Interação, o diálogo com a Secretaria de Habitação do município foi facilitado, abrindo portas para a experimentação da metodologia naquela localidade, com aval do governo local.

Ainda receosos e descrentes de projetos de transformação social desenvolvidos pelo Estado ou por ONGs, os moradores da comunidade foram gradativamente motivados a participar da

\footnotetext{
${ }^{18}$ Estudos futuros que contemplem especificamente a forma como o capital social é promovido e fortalecido naquela comunidade serão de grande valia para compreender como são instrumentalizadas e percebidas as relações de poder, sobretudo do ponto de vista de seus impactos nos resultados obtidos pela ação, com respectivos desdobramentos ao longo do tempo.
} 
iniciativa. Sem a presença de lideranças formais ou instituições locais que representassem os interesses das pessoas no campo, o capital humano era disperso, ou seja, não havia conhecimento das capacidades existentes e eram raras as iniciativas de ação coletiva, sempre frustradas. O início da mobilização deste capital humano deu-se através do diálogo e da troca de experiências entre moradores locais, fundadores e técnicos da Interação e representantes de outras comunidades, como uma comissão vinda da África do Sul. As reuniões eram feitas em locais improvisados ou até no meio da rua, conforme a possibilidade da própria comunidade. Dos 16 moradores inicialmente inscritos para participar do projeto, apenas nove aportaram recursos financeiros no primeiro grupo de poupança. Através do convencimento feito entre vizinhos e da adesão de lideranças informais, a primeira conta bancária do grupo foi aberta com 21 poupadores e um montante de R \$210,00. Mas foi o acesso à Secretaria de Habitação, por meio de reuniões regulares, que legitimou a ação dos agentes no campo, ampliando a mobilização do capital humano e, a partir de então, capital financeiro da própria comunidade. Com contribuições que variavam entre dez centavos e poucas dezenas de reais, em 2007 já havia cinco grupos de poupança compostos por 150 famílias.

Uma interação de caráter operacional construída com um agente bancário - a agência da Caixa Econômica Federal - representou um desafio à atuação dos agentes no campo. A superação das burocracias necessárias para a abertura e a movimentação de contas por aquelas pessoas, condição fundamental para a efetivação e a transparência dos grupos de poupança, só foi possível, segundo os entrevistados, pelo estabelecimento de uma boa relação com o gerente daquela agência. A aparentemente simples interação entre os tesoureiros dos grupos de poupança e a entidade bancária envolveu, portanto, a mobilização de diferentes tipos de capital: financeiro, operacional e humano. Nesta interação entre a comunidade e a agência bancária, o capital financeiro foi constituído pelos recursos poupados pela comunidade. $\mathrm{O}$ capital operacional, ou seja, a capacidade de apoiar institucionalmente a execução de ações no campo, foi mobilizado por meio da flexibilização e facilitação de procedimentos burocráticos por parte da instituição bancária. E o capital humano foi mobilizado em via de mão dupla entre os agentes, pela construção de uma relação de respeito e confiança para a realização de ações em prol do desenvolvimento da comunidade.

O capital financeiro necessário para a urbanização da área e construção das moradias foi obtido junto ao Ministério das Cidades, dentro do Programa de Aceleração do Crescimento, "por sorte" como relata um dos moradores, uma vez que o acesso a recursos públicos, outras 
vezes tentado, nunca tivera êxito. Recursos financeiros aportados pelo município nesta ação foram empregados no pagamento de bolsa-aluguel para os moradores durante as obras no local, e na compra do terreno, que é uma propriedade privada. Parte dos recursos da poupança comunitária foi utilizada pelos moradores para acabamento dos imóveis que estão sendo entregues desde 2010.

Implantados no bairro a partir da urbanização, a Casa de Cultura e o Centro de Inclusão Digital são os únicos equipamentos de educação para o trabalho, cultura e lazer da comunidade. Oferecem cursos profissionalizantes, atividades educacionais e lúdicas, mobilizando capital operacional e dando apoio institucional ao processo de desenvolvimento comunitário. Adicionalmente, a Casa de Cultura cede espaço para a realização de reuniões e atividades comunitárias.

\subsubsection{Disposições do campo}

Os agentes que interagem no campo onde o empreendimento social desenvolve suas atividades de apoio à Comunidade dos Portais partilham de determinadas disposições, ou seja, conforme acepção de Bourdieu, partilham de um conhecimento tácito que determina ações e percepções ao integrar experiências passadas e impor regularidades ao funcionamento do campo. (MICELI, 2007; MISOCZKY, 2003).

Essas disposições presentes no campo são profundamente determinadas pelas trajetórias das 600 famílias que moraram na área, enquanto ainda era uma favela. Geralmente migrantes oriundos de estados da região nordeste do país, são pessoas que repentinamente se viram impelidas a morar em favelas. Por convite ou sugestão de amigos, como última opção de moradia, compraram os barracos que originaram a Comunidade dos Portais. As principais causas desta condição foram o desemprego, as separações conjugais e a vinda para o estado de São Paulo sem uma rede de apoio para acolhimento e encaminhamento a melhores condições de trabalho e habitação.

Para algumas pessoas, viver em condições precárias nos barracos de madeira, com alto risco de incêndio, umidade constante, calor, goteiras, circulação de ratos e outros animais, foi o fato desencadeador de atitudes de revolta e indignação. Outras pessoas desenvolveram resignação 
e indiferença frente àquela realidade. Do primeiro grupo, emergiram as lideranças que concretizaram os objetivos do projeto, mobilizando vizinhos e criando grupos de poupança para implantação da proposta trazida pela Interação. O segundo grupo, composto pela grande maioria dos moradores, permaneceu à margem do processo, geralmente manifestando desconfiança quanto às intenções do empreendimento social e/ou dos agentes públicos envolvidos.

De modo geral, os moradores sentiam-se injustiçados por terem sido "escondidos" e "esquecidos" na favela onde moravam, como enfatizam dois informantes. Tentativas de diálogo com a Secretaria Municipal de Habitação eram sempre frustradas, assim como foram os movimentos de organização local e iniciativas de ajuda externa, tanto as conduzidas pelas mãos de políticos locais quanto aquelas trazidas por organizações de outros setores. Disposições que enfatizavam a descrença e a desconfiança dos moradores foram impactadas pela possibilidade de diálogo com a Prefeitura Municipal, trazida pela Interação. Essa possibilidade, ao se concretizar, foi o principal alavancador para a adesão de algumas pessoas à ação proposta pelo empreendimento social.

Pelo diálogo e a possibilidade concreta de ascender a um patamar diferenciado de negociações com o poder público, consolidou-se a crença de algumas pessoas de que, sem pressão e diálogo, o Estado não resolveria o problema habitacional daquela comunidade, e que era necessário construir tal acesso. Para tanto, cabia às pessoas minimizar a passividade, recobrando a autoestima e a luta pela dignidade. A participação e a organização comunitária, fomentadas por meio dos grupos de poupança, aos poucos foram reconhecidas pela comunidade como formas de obter diálogo com o poder público através das pontes criadas pela Interação junto à Secretaria Municipal de Habitação.

As trajetórias das pessoas responsáveis pela implantação da metodologia do SDI também foram determinantes para a consolidação de disposições que caracterizam o desenvolvimento da iniciativa. Com vasta experiência na área de habitação, desenvolvida junto a instâncias governamentais e movimentos sociais, os fundadores da Interação ambicionavam aplicar uma metodologia que complementasse a ação do poder público, agregando agilidade, inovação e economia de recursos para realização do diagnóstico local, além de otimizar resultados com dados mais apurados e fomento da participação comunitária. 
Guiada por esses ideais, a Interação foi criada com a missão de

contribuir para que as comunidades em assentamentos precários no Brasil conquistem seus direitos de cidadania e moradia por meio da organização comunitária e reconhecimento de seu potencial transformador e multiplicador. (Interação - documento institucional)

Houve convergência entre os princípios da metodologia aplicada pela Interação e as crenças de parte dos moradores da Comunidade dos Portais, que nutria revolta e indignação em face daquelas condições de vida. Essa convergência foi determinante para que ação se concretizasse no campo, pautada em disposições que levaram os agentes a realizar ações locais em prol da transformação física e social.

Uma vez fortalecido um conjunto de disposições favoráveis ao estabelecimento de novas condutas no campo, rompendo com a passividade e a desconfiança, a ação do empreendimento social no campo foi orientada para a transformação social por meio da compreensão de si e do coletivo, do fortalecimento comunitário, da gestão democrática e da troca de conhecimentos.

Desta forma, os participantes tornam-se protagonistas, ou seja, participam diretamente no processo de conceber e executar as políticas e programas governamentais. (Interação - documento institucional)

Para tanto, a proposta do empreendimento social foi qualificar a Comunidade dos Portais, estimular sua organização e a participação ativa dos moradores, bem como o fomento de lideranças femininas.

Entretanto, a criação dos grupos de poupança, metodologia implantada com sucesso em outros países, ainda esbarrava em dificuldades impostas por algumas disposições presentes no campo. Do ponto de vista da Interação, fazia muito sentido incluir as comunidades na economia através do aumento da poupança e da capacidade de investimento, assim como acontece na economia nacional. Mas o movimento social, de modo geral, é receoso ou avesso à instrumentalização de aspectos monetários. A proposta de constituição de grupos de poupança foi recebida por muitos moradores como um possível golpe; havia o receio 
disseminado de que pudessem ser roubados no pouco que tinham e conseguissem economizar. Embora estivesse previsto na metodologia que a gestão integral dos recursos poupados seria da própria comunidade, esse receio era de tal forma enraizado que não permitia às pessoas, racionalmente, compreender as reais implicações da formação dos grupos.

Uns poucos moradores atribuíram credibilidade à proposta, observando que a Interação não apresentou promessas, apenas possibilidades baseadas em experiências concretas de comunidades ainda mais pobres. A inexistência de valores mínimos ou predefinidos para a poupança, associada à responsabilização da própria comunidade pela administração dos recursos, minimizou a percepção de risco pessoal. Por fim, os técnicos do empreendimento social envolvidos nessa etapa introdutória tiveram importante papel, não só ao mobilizar o capital político que permitiu o acesso ao poder público, mas ao reconhecer o capital intelectual que mobilizaram, conquistando a empatia e a admiração da comunidade. A Interação foi entendida por esse grupo pioneiro de poupadores, como um agente que buscava, sem interesse político ou pessoal, ajudar a mudar uma situação com a qual todos estavam insatisfeitos.

A constituição do primeiro grupo de poupança e a subsequente concretização de um resultado desejado por ampla parcela da comunidade - o acesso à Secretaria de Habitação -, foram fatores determinantes para a criação de um vínculo de confiança entre a comunidade e a proposta da Interação. Embora o objetivo final dessa ação fosse a urbanização da área, o principal motivador era, naquela fase incipiente, a possibilidade de levar as reivindicações comunitárias às autoridades competentes: o simples fato de ser ouvido para a efetiva solução do problema, de ser visto e reconhecido com cidadão.

A participação nas reuniões dos grupos de poupança tornou-se forte motivador para a adesão das pessoas à proposta. O desejo de "estar junto", “conversar", "discutir", "brincar” já era característico da cultura daquelas pessoas, que passavam a maior parte do dia fora de suas casas, interagindo com vizinhos nas ruas. A reunião era mais um momento para promover essa união, aumentando uma proximidade que já existia. Complementarmente, os intercâmbios com comunidades de outros estados e países propiciaram o conhecimento e o compartilhamento de experiências, ampliando as fronteiras dessa forma de socialização. 
Uma vez estabelecido no campo o conjunto de disposições que enfatizaram o fortalecimento comunitário, as relações entre os agentes no campo passaram a ser pautadas pela criação de condições para urbanização da área, objetivo primeiro e maior da mobilização local.

\subsubsection{Contribuições do Empreendimento Social}

A metodologia desenvolvida pelo SDI já foi aplicada com sucesso em 32 países da África, Ásia e América Latina, mobilizando mais de 340.000 pessoas residentes em favelas e assentamentos precários. Só na África do Sul, já foram construídas mais de 20 mil casas.A Interação foi responsável pela aplicação desta metodologia em 10 cidades brasileiras e duas bolivianas, mobilizando mais de 42.000 pessoas residentes em áreas semelhantes.

O propósito de contribuir para o desenvolvimento econômico, urbano e social de comunidades em áreas com alto grau de vulnerabilidade social é um dos principais objetivos da Interação, e tem sido buscado por meio de estratégias de mobilização comunitária. Sua atuação consiste, fundamentalmente, no suporte técnico para que as comunidades busquem seu próprio desenvolvimento a partir de iniciativas que garantam melhoria das condições de habitação, educação financeira, geração de renda, preservação ambiental e cidadania.

A metodologia empregada pela Interação gera transformações no plano coletivo e no plano pessoal. No plano coletivo, contribui para que as comunidades, geralmente fragmentadas, se conheçam melhor, fortaleçam vínculos e busquem objetivos comuns. No plano individual, a metodologia tem se mostrado favorável ao resgate da autoestima e do conceito de cidadania, por estimular a capacidade de percepção e ação.

A aplicação da metodologia do SDI pela Interação no Brasil foi feita com os cuidados requeridos para um projeto-piloto. A escolha da Comunidade dos Portais deu-se após a constatação de que a iniciativa não competiria com outras ações em curso naquela favela, pois inexistiam, e também de que não iria contrariar os interesses de políticos da região, os quais poderiam prejudicar o trabalho. O acesso facilitado à Secretaria de Habitação de Osasco contribuiu para o estabelecimento de uma boa relação com a Prefeitura Municipal, que apoiou a iniciativa desde o início e apresentou o empreendimento social à comunidade. Esse envolvimento da Prefeitura Municipal e da Secretaria de Habitação veio ao encontro da 
necessidade percebida pela comunidade de estabelecer um canal de comunicação com o poder público, uma das principais contribuições aportadas pela Interação.

A conquista da confiança da comunidade é atribuída à humildade e transparência com que a Interação estabeleceu os primeiros contatos com os moradores. A busca do diálogo associada à reafirmação da ausência de interesses políticos, de promessas e de compromisso de longo prazo foi a estratégia usada para criar relações de colaboração. Buscou-se, nesse primeiro momento, demonstrar para a comunidade que ela seria a protagonista da ação, cabendo ao empreendimento social apoiá-los tecnicamente, confirmando que o risco era mínimo. Poderia não dar certo, mas ninguém seria prejudicado se isso acontecesse.

Desde o início, o projeto não se resumiu a conseguir casas para a comunidade, embora essa tenha sido a contribuição mais palpável da ação. O suporte dado pela Interação fundamentouse, principalmente, na conscientização das pessoas quanto à necessidade de organização coletiva para sistematizar suas demandas e, então, dialogar com o poder público, rompendo com o acesso de balcão, individual. A partir da organização local, o empreendimento social deu suporte e acompanhamento técnico para o estabelecimento de diálogo entre a comunidade e a prefeitura. Num estágio inicial, coube à equipe do projeto traduzir os códigos da linguagem do poder público para a linguagem popular, tornando-os compreensíveis para a comunidade e permitindo que, posteriormente, as partes tivessem condições de dialogar diretamente.

Nesse processo, foram identificadas lideranças e pessoas ativas na comunidade, as quais levaram a cabo a mobilização local, ou seja, a criação e o fomento dos grupos de poupança e a interlocução com a Secretaria de Habitação. A adesão dessas lideranças à proposta do empreendimento social foi um importante fator de geração de credibilidade para o projeto frente à comunidade, contribuindo para a superação dos receios e das resistências iniciais.

Para que todo esse processo atingisse os objetivos pretendidos, foi necessária uma avaliação por parte do empreendimento social, ainda que subjetiva, sobre a aceitação e o comprometimento da comunidade com a ação proposta. Concretamente, a observação recaiu sobre a disponibilidade das pessoas para participar das reuniões, dos intercâmbios e das ações de apoio a outras comunidades. Avaliou-se também a maturidade do grupo, o quanto os interlocutores encontravam-se maduros para ter um diálogo mais qualificado com a prefeitura, 
para fomentar a mobilização e, consequentemente, desencadear o processo de transformação. Dessa forma, o empreendimento social buscou assegurar que a comunidade teria condições de assumir o papel de protagonista da ação, contribuindo para sua própria autonomia. À medida que as pessoas percebem sua responsabilidade, a organização local ganha força, e se reduz a necessidade de apoio do empreendimento social.

A aplicação dos três eixos de ação, conforme preceitos da metodologia do SDI forneceu importantes contribuições para a Comunidade dos Portais.

Com o autorrecenseamento, as 600 famílias que moravam naquela área tiveram aumentado o seu grau de informação sobre as características e particularidades de cada habitação. Foram mapeadas as necessidades do grupo, com a identificação precisa da quantidade de idosos, crianças e pessoas portadoras de deficiência, por exemplo; além disso, a fidedignidade dos dados coletados levou este censo a ser aceito pela Secretaria Municipal de Habitação como a base a ser utilizada no planejamento do conjunto habitacional que substituiu a favela, ainda que determinadas características, como a densidade de crianças e de jovens, não fossem adequadamente contempladas na elaboração e na execução do projeto.

Os diversos intercâmbios realizados, com a visita de moradores dos Portais a outras cidades e países, e com a recepção de visitantes de outras comunidades contribuiu, principalmente, para o aumento da "vontade de mudar", como relata um morador. Ao se compararem com pessoas em piores ou em melhores condições, os moradores daquela comunidade desenvolveram a crença de que todas as pessoas têm capacidade de mudar sua situação. Além disso, a simples possibilidade de sair do seu bairro, do seu município e chegar a outros países era impensável para a grande maioria das pessoas que fizeram intercâmbios, e essa experiência contribuiu para a valorização pessoal e o fortalecimento da autoestima.

A poupança comunitária, como já comentado, teve forte impacto na criação e no fortalecimento da organização dos moradores em grupos os quais, orientados para objetivos comuns, propiciaram espaço e tempo para a troca de ideias, reflexões, questionamentos e proposições acerca dos problemas locais. As reuniões também se tornaram ocasiões para a criação e o fortalecimento de amizades, fomentando o capital social. O montante de recursos poupados superou as expectativas da equipe da Interação em mais de 50\%. Esses recursos 
foram, com o retorno das famílias para as novas moradias, utilizados no acabamento dos imóveis e ainda continuam investidos para necessidades futuras, demonstrando a consolidação de uma cultura de poupança entre as pessoas envolvidas no projeto.

Para o empreendimento social, as contribuições aportadas por essas três ações autorrecenseamento, intercâmbios e poupança comunitária - devem-se fundamentalmente ao rigor com que foram observados os aspectos e nuances contidos na metodologia, já largamente testada e validada. Ainda que pequenas adaptações tenham sido feitas, os pressupostos mais básicos devem ser observados, cuidando para evitar erros na aplicação. Destaca-se a importância de manter a ênfase na participação das mulheres, para que elas continuem protagonistas; de manter três tesoureiros ativos em cada grupo, evitando a criação de lideranças isoladas; e de incentivar a participação de diferentes pessoas nos intercâmbios.

Um importante passo para aplicação da metodologia é a identificação e preparação de lideranças locais, ainda que informais. Visando evitar a criação de hierarquias e centros de poder, o processo é feito de modo a evitar o "culto à liderança". Para isso, o foco do trabalho está na estruturação dos grupos, e as lideranças são capacitadas pela equipe do empreendimento social para compreender o papel e a responsabilidade que assumem em um modelo horizontal de atribuição de poder.

A metodologia aplicada buscou fomentar a mobilização local, a organização comunitária e a horizontalidade do poder e das responsabilidades. Entretanto, observa-se que esses três fatores perderam força com a concretização da urbanização da área, frustrando algumas expectativas dos empreendedores sociais e dos líderes comunitários envolvidos com a ação. Diversos fatores contribuíram para que isso acontecesse.

Num primeiro momento, houve grande dispersão dos moradores durante o longo período de construção das moradias, o qual se estende até este ano. Despreparadas para este processo, as pessoas foram morar em bairros distantes e perderam contato entre si, enfraquecendo os grupos de poupança e os vínculos mantidos pelas relações de proximidade.

A preparação das pessoas para o retorno às novas moradias foi feita de forma pouco planejada, resultando na inexistência de regras de convivência e na baixa conscientização sobre as demandas ainda existentes na comunidade. Observa-se que, em geral, Prefeituras e 
Secretarias de Habitação têm reduzida capacidade operacional e, até mesmo, carência de uma cultura orientada para a fase pós-ocupação de áreas urbanizadas. Essas instâncias estão mais habituadas a concentrar sua atenção nas fases de projeto e execução das obras, tendo por objetivo final a entrega das casas. Além disso, embora a alocação dos moradores tenha sido feita com base em critérios acordados por todos os agentes, na prática, ela resultou em uma miscelânea de famílias das diferentes favelas que compunham a comunidade dos Portais, separando fisicamente antigos vizinhos. Com a perda destes laços de proximidade, não raro as pessoas mal se cumprimentam nos corredores dos prédios e nas ruas, reforçando a perda da capacidade de organização e fomentando uma cultura mais individualista.

De fato, a percepção de que as pessoas são hoje mais individualistas do que à época em que moravam na favela é comum entre os moradores. Além das questões relacionadas à fase de pós-ocupação da área, o empreendimento social vê fatores culturais que influenciam esta dinâmica. Principalmente em comparação com Índia e África, nos países da América Latina predomina uma cultura que reforça o individualismo, em detrimento da coletividade. Em geral, há o objetivo de melhorar a própria vida, a vida da família, e isso raramente está atrelado ao objetivo de mudar o local onde se mora e as condições da comunidade. Ao contrário, a meta costuma ser a compra de uma casa melhor em outro bairro, quando possível.

Destaca-se, ainda, o fato de que o crescimento econômico dos últimos anos propiciou maior acesso a emprego e significativo aumento de renda, sobretudo para as classes C e D. Nesse contexto, os moradores da Comunidade dos Portais passaram a ter mais tempo dedicado ao trabalho e estudos, além de mais renda destinada a opções de lazer. Sob a prerrogativa da falta de tempo, as pessoas deixaram de participar das reuniões e das redes que foram criadas, atribuindo a identificação, a discussão e o encaminhamento de demandas da comunidade às lideranças que se mantiveram mais ativas ao longo de todo o processo. Se, no início do projeto, a participação nas reuniões contabilizava dezenas de pessoas, após a remoção e o retorno de algumas famílias, menos de uma dezena participa desses encontros mensais.

A falta de um novo objetivo comum, que extrapolasse a construção das casas e mantivesse as pessoas unidas, também é identificada como um dos fatores para o enfraquecimento da organização local. $\mathrm{Na}$ realidade, objetivos comuns existem, e eles estão relacionados aos desafios que a comunidade enfrenta em sua nova realidade - regras de convivência, 
regularização da documentação, administração condominial, segurança pública, provisão de equipamentos e serviços de saúde, educação, lazer, cultura, entre outros. Mas estão, de certa forma, delegados pela comunidade ao grupo de líderes que ainda se mostra engajado no processo de mudança, e que acabou se tornando representante dos interesses coletivos.

\subsubsection{Resultados para o desenvolvimento social}

Dentre os objetivos pretendidos pela Interação no seu trabalho junto a comunidades em habitações precárias, um deles é explicitamente voltado para a "promoção do desenvolvimento econômico, social e combate à pobreza”. Reforçando aspectos inerentes ao desenvolvimento social, sobretudo na esfera do empoderamento ou do capital político e social, o empreendimento social aspira "garantir a promoção da ética, paz, cidadania, direitos humanos, democracia e outros valores universais", bem como "estimular a liderança e o fortalecimento da mulher". A promoção do bem-estar social e da riqueza material constituem “objetivos-meio" para o alcance dos objetivos destacados. Essas dimensões estão contempladas nos objetivos que encerram os aspectos metodológicos orientando a ação do empreendimento: "estimular e capacitar organizações comunitárias em prol da obtenção da moradia digna e formal, promovendo troca de experiências, ideias, estratégias e recursos"; e "implementar a metodologia participativa constituída pelo autorrecenseamento, poupança comunitária e intercâmbio".

Com as ações realizadas desde que iniciou suas atividades em 2005, o empreendimento social destaca ter obtido resultados no âmbito da formulação e da operação de políticas públicas, por meio do estabelecimento de canais de comunicação entre cidadãos e governos, favorecendo a boa governança. Resultados voltados para a redução das desigualdades são identificados no acesso a melhores condições de habitação e a oportunidades de geração de renda, com maior participação de mulheres nos processos decisórios.

A ação realizada pela Interação junto à Comunidade dos Portais resultou em ganhos nas três dimensões do desenvolvimento social estudadas: riqueza material, bem-estar social e empoderamento.

Os principais resultados obtidos, em termos de concretude e de relevância para a comunidade, foram a urbanização e a entrega das casas para os moradores. Dessa conquista, derivaram 
mudanças na vida das pessoas que dificilmente teriam sido obtidas por outros meios, pois estavam atreladas a dois fatores inerentes à vida na favela: o preconceito e a invisibilidade. Sair da favela, ou transformá-la, era condição fundamental para que ocorresse um mínimo progresso em termos de desenvolvimento social.

Muito embora ainda esteja em curso a regularização do terreno onde se localizavam as favelas e, por consequência, das casas construídas com a urbanização, os moradores já têm um endereço oficial, atribuído pela Prefeitura Municipal, e que passou a constar em documentos comprobatórios de residência. Anteriormente, a inexistência desta comprovação foi responsável pela perda de oportunidades de emprego, por demissões e até por dificuldades para a matrícula das crianças na rede pública de ensino. Moradores relatam ter sido vítimas de preconceito por morarem em favela. Lojas locais não faziam entregas na comunidade, mesmo de bens já quitados, e até mesmo recenseadores do IBGE tinham receio de percorrer a favela, deixando de registrar a existência e as condições de vida daquelas pessoas. Como relata um morador, viver em uma favela fazia com que ele se sentisse pequeno frente a pessoas com melhores condições de vida, sem direitos frente ao poder público, sem perspectivas além da sobrevivência diária.

Ter uma casa em um conjunto habitacional, com endereço oficial, produziu significativo impacto sobre a autoestima das pessoas. Figurar em uma estatística feita pelos próprios moradores por meio do autorrecenseamento, reconhecido pelo governo local, contribuiu para que se sentissem detentores de direitos. Nesse processo, sair da invisibilidade e superar o preconceito são resultados que assinalam importantes mudanças obtidas no âmbito individual. $\mathrm{Na}$ esfera da riqueza material, essas mudanças influenciaram resultados, como o acesso a crédito, à aquisição de bens de consumo e a serviços. Além de cidadãos, os moradores da comunidade tornaram-se clientes.

No período em que as transformações foram operadas - entre 2005 e 2010 -, o contexto econômico do país manteve-se favorável à criação de oportunidades para as classes $\mathrm{C}$ e D. Segundo a Secretaria de Assuntos Estratégicos, ligada à Presidência da República, 15\% da população brasileira ascendeu à classe média nos últimos 10 anos, a qual é composta, em 2012, por 104 milhões de pessoas. (SAE, 2012). A expansão da oferta de emprego, o aumento real da renda e o incentivo ao consumo coincidiram com as mudanças estruturais e pessoais 
vivenciadas por aquela Comunidade. $\mathrm{O}$ acesso a oportunidades de trabalho foi um resultado facilitado por este contexto: embora não existam números, os moradores constatam que há, atualmente, uma quantidade bem maior de pessoas empregadas ou ocupadas. Mais especificamente, o processo apoiado pelo empreendimento social influenciou este resultado por motivar as pessoas para a ação, para aumentar o impacto das mudanças em suas vidas e até construir redes de relacionamento através dos grupos de poupança, que tornaram as oportunidades de trabalho mais visíveis e próximas. Além do aumento da renda, o acesso a emprego formal em regime CLT tem proporcionado benefícios complementares à remuneração e benefícios sociais. $\mathrm{O}$ acesso à poupança e à renda permitiu, ainda, que os moradores investissem recursos no acabamento das casas, na compra de móveis e utilidades domésticas. Emprego, renda e consumo são evidências das mudanças ocorridas na esfera da riqueza material.

A busca de conhecimento é um dos resultados obtidos na esfera do bem-estar social. A capacitação profissional para abrir um negócio próprio dentro da comunidade, a graduação em serviço social para conhecer seus direitos e os direitos coletivos, o curso de inglês para beneficiar-se mais dos intercâmbios proporcionados pela Interação são alguns exemplos das mudanças experimentadas pelas pessoas em sua educação formal e complementar.

Mas são as mudanças físicas que mais se destacam entre os resultados na esfera do bem-estar social. Ter um lugar confortável para morar significa, para os moradores entrevistados, deixar de conviver com o risco iminente de incêndios e enchentes, com roedores e outros animais, com a falta de saneamento básico; ter a intimidade preservada por paredes de alvenaria; ter cômodos adequados para todos os moradores da casa, com quartos separados para crianças e adultos. As pessoas sentem prazer em retornar a suas casas após o trabalho, o que estimula a convivência familiar. E têm prazer em cuidar de suas casas, o que antes não acontecia; a aquisição de móveis, acabamentos e utensílios era mais dificultada pela insatisfação por morar em um barraco do que pela ausência de recursos financeiros. As pessoas orgulham-se do acabamento e decoração que escolheram para suas casas, da presença de televisores modernos, acesso a internet e telefonia, embora esta ainda seja precária. Muitos adquiriram automóveis, trocaram por modelos mais novos, ou planejam a compra do primeiro carro.

O acesso a melhores condições de bem-estar são ainda mais valorizadas por pessoas que conceberam ou tiveram filhos enquanto moravam em barracos. A angústia de ver os bebês e 
crianças em condições muito precárias de vida foi um forte motivador para que alguns dos moradores da comunidade perdessem o receio de aderir ao projeto proposto pela Interação, o que em certa medida caracteriza o perfil das pessoas que compuseram o "Grupo de Vanguarda" do projeto, como denominado por um dos fundadores do empreendimento social.

Ainda na esfera do bem-estar, o conjunto habitacional contempla um pequeno núcleo de reciclagem de materiais, operado por um grupo de moradores, que veio a substituir o processamento informal feito em uma das casas da extinta favela. Embora tenha resultados efetivos na geração de renda associada à preservação ambiental, não há consenso entre os moradores quanto a resultados positivos trazidos pelo núcleo para a comunidade. Aparentemente, o grau de informação e sensibilização para a separação de materiais recicláveis não tem sido suficiente para que as pessoas façam a coleta seletiva. Muitos reclamam dos pontos de coleta, alegando ter lixo e animais na porta de casa.

O acesso ao governo local - Prefeitura Municipal, Secretaria Municipal de Habitação e outras secretarias - foi uma das grandes mudanças vivenciadas pela comunidade dos Portais na esfera do empoderamento das pessoas. Outro importante resultado da mobilização apoiada pela Interação foi o acesso a recursos do Programa de Aceleração do Crescimento do Governo Federal, para urbanização da área e construção das moradias. Com a urbanização, a comunidade ampliou o seu acesso a programas municipais de proteção e promoção da saúde, uma vez que os agentes públicos de saúde deixaram de ter receio de adentrar a comunidade e passaram a visitar os moradores periodicamente.

Os avanços na esfera do empoderamento das pessoas também são observados no acesso à educação e cultura. A instalação de uma escola municipal ao lado do conjunto habitacional facilitou a ida das crianças à escola. Também próximo à comunidade foram instalados o Centro de Inclusão Digital - CID e a Casa de Cultura, a qual oferece aulas de teatro, dança, música, eventos e outras atividades culturais. O CID foi uma importante conquista, por ter sido idealizado pela comunidade e obtido em negociação direta com a Secretaria do Trabalho.

As mudanças relatadas contemplam, e ao mesmo tempo refletem, a busca conjunta por melhores condições de vida, e beneficiaram toda a comunidade, independentemente da participação ou não no processo de construção destas conquistas. Outras importantes 
mudanças na esfera do empoderamento, entretanto, são observadas apenas no grupo de pessoas ativas neste processo, sobretudo os tesoureiros dos grupos de poupança.

Uma importante mudança foi o desenvolvimento do capital social e político da comunidade pela constatação de que os políticos e o Estado não atenderiam espontaneamente e nem rapidamente às suas demandas, embora até então se acreditasse que esse seria o curso normal das coisas. Houve a conscientização de que a mobilização e a organização comunitárias eram necessárias para que as mudanças acontecessem. Atualmente, este fato é reafirmado pelos moradores entrevistados quando comparam a condição que têm hoje nos Portais com as condições de uma favela que estão apoiando, a qual, em 40 anos de existência, não teve benesses do estado, mantendo-se em situação bastante precária. Essa constatação, entretanto, não foi e não é introjetada por todos, nem compreendida pela maioria.

A participação de todas ou da grande maioria das famílias na etapa de constituição dos grupos de poupança era um resultado desejado pela Interação e provavelmente teria sido responsável por uma maior e mais consistente abrangência dos resultados obtidos, sobretudo na esfera do empoderamento. A constituição dos grupos visava ir além da conquista do direito à moradia e urbanização; visava criar e fortalecer o capital social daquela comunidade, de modo que ela se tornasse capaz de, por seus próprios recursos, criar e gerir o seu processo de transformação local, como propõem Arns et al (2003). Mas como o acesso à moradia era o objetivo mais palpável da ação, e esse acesso deve ser garantido pelo poder público de forma universal, a participação nos grupos de poupança era entendida pela maioria das pessoas como desnecessária, uma vez que havia um grupo tomando a frente das negociações.

$\mathrm{Na}$ avaliação da Interação, embora o desenvolvimento do projeto não tenha contado com ampla participação das famílias, dado o grau de vulnerabilidade, desagregação e desorganização da Comunidade dos Portais, o compromisso com o desenvolvimento individual e coletivo entre os moradores participantes foi expressivo.

O fortalecimento do capital social deu-se à medida que se desenvolvia um sentimento de cooperação entre as pessoas participantes do projeto, criando-se, de um pequeno grupo que acreditou na possibilidade de transformação pessoal e coletiva, um grupo que se dispôs a ser porta-voz da comunidade e a trocar experiências com outros assentamentos precários. Essas pessoas compartilham a crença no apoio mútuo frente às dificuldades, mantendo-se 
disponíveis para cooperar e ajudar. Mesmo abrindo mão do seu tempo de lazer ou de outras prioridades particulares, estão dispostos a transmitir a experiência que tiveram, trazendo e levando conhecimento. A empatia também se fortaleceu neste processo, pela criação da capacidade de se colocar no lugar do outro e por seus problemas e dificuldades pessoais em perspectiva. Em geral, os moradores que tomaram e ainda tomam a frente da iniciativa de transformação local orgulham-se por terem protagonizado o processo, por terem sua dedicação e crença reconhecidas pela família, ainda que antes houvesse pouco apoio. Orgulham-se por terem aprendido a acreditar em si mesmos e em sua capacidade de realização.

Com a urbanização, entretanto, esse capital social "embrionário" teve seu desenvolvimento aparentemente estacionado. $\mathrm{O}$ individualismo, como já discutido, tem sido identificado pelo grupo de pessoas atuantes no projeto como muito presente. A falta de disponibilidade para participar das reuniões e de vontade para discutir e resolver os problemas da comunidade é patente. A força-motriz do processo de transformação local foi enfraquecida pelos resultados obtidos na esfera do bem-estar: a mudança do status habitacional com moradia digna, melhores condições de vida, alguma segurança sobre a posse das propriedades, o endereço oficial. Embora os resultados tenham sido significativos, não foram suficientes para evitar a desmobilização dos moradores. Por consequência, a administração condominial, assim como a existência, o amplo conhecimento e aceitação de regras de convivência, são fundamentais para que o bem-estar coletivo seja assegurado, sob pena de resultar em um processo de enfraquecimento do capital social. Questões na área de segurança pública, por exemplo, vão exigir ampla mobilização para serem equacionadas a tempo de evitar maiores danos para a comunidade.

As evidências revelam que a ação do empreendimento social contribuiu para que a comunidade conseguisse, intencionalmente, remover condições que causavam a privação de certas liberdades, tal como proposto por Sen (2000). A expansão das liberdades individuais, objetivo do desenvolvimento na visão daquele autor, é percebida em aspectos como a redução da desigualdade no acesso a emprego, renda e consumo; o reconhecimento de direitos civis e o acesso a instituições e programas governamentais; a melhoria no acesso a educação e saúde. 
A ampliação de capacidades da Comunidade dos Portais decorre visivelmente do processo de desenvolvimento local realizado por um grupo de moradores, com reflexos em toda a comunidade. Com apoio técnico da Interação, esse desenvolvimento ocorreu através da construção de uma identidade territorial e da mobilização de recursos locais - principalmente os econômicos, humanos e institucionais, gerando riqueza e qualidade de vida, como propõem Brito e Zapata (2004). O fortalecimento do capital social, como observam Milani (2003) e Kliksberg (2007), foi um importante alicerce para o desenvolvimento local. A participação ativa da própria comunidade no diagnóstico de sua realidade, assim como no planejamento, na produção e na gestão de ações, recursos e ativos, como propõe Gomes (2005), são características que reforçam o processo de desenvolvimento local ocorrido naquela comunidade. Ainda que o individualismo e a desmobilização presentes após a urbanização possam significar perda de força no processo de desenvolvimento local, o aprendizado da comunidade e a existência de lideranças que acreditam no potencial endógeno de transformação são fatores que podem vir a fomentar novas ações orientadas para a contínua promoção do desenvolvimento social em âmbito local, através da expansão de liberdades individuais.

\subsection{Análise conjunta dos casos estudados}

\subsubsection{Características de contexto: campo, agentes e capitais}

Neste estudo, os contextos nos quais os empreendimentos sociais desenvolvem suas atividades foram descritos sob a ótica da constituição de campos formados por diferentes agentes que estabelecem variadas formas de interação. Os campos, conforme acepção de Bourdieu, são espaços sociais historicamente constituídos, nos quais as posições ocupadas pelos agentes se determinam pela distribuição desigual do capital que eles detêm e mobilizam, ou seja, pelo tipo de poder e influência que exercem no campo. Desta forma, as relações e interações estabelecidas entre os diferentes agentes presentes nos campos influenciam a ação dos empreendimentos sociais, assim como os resultados obtidos.

Em primeira instância, os empreendimentos sociais relacionam-se com os grupos de pessoas que serão beneficiadas em cada iniciativa desenvolvida. Nos casos estudados, esses grupos 
são compostos pelos trabalhadores cooperados que foram capacitados e assessorados pela Aliança Empreendedora, pela comunidade que recebeu apoio da Interação e pelos empreendimentos contemplados no Fundo Zona Leste Sustentável.

Num segundo patamar de interações, os financiadores dos projetos realizados pelos empreendimentos sociais exercem forte influência no campo, na medida em que são responsáveis pelos custos de implementação das ações. Estes custos variam em função da complexidade da iniciativa e da centralidade que o poder econômico assume no projeto. Por exemplo, o Fundo Zona Leste Sustentável tem como pressuposto a mobilização dos empreendedores locais por meio do apoio financeiro aos seus negócios. Exige, portanto, elevados aportes financeiros a cada nova edição, os quais vão além dos custos com recursos humanos e materiais inerentes à execução do projeto, pois é necessário capitalizar o próprio Fundo. Já a metodologia empregada pela Interação está fundamentada na mobilização comunitária por meio da soma de esforços dos próprios moradores do território onde a iniciativa se desenvolve. Seus custos de implementação limitam-se a contratação de equipe técnica, despesas de campo e custeio de viagens de intercâmbio, as quais são realizadas esporadicamente.

Apesar das diferenças encontradas no tipo de aporte financeiro requerido por cada projeto, um traço é comum a eles: seu financiador detém o poder de alimentar ou de encerrar a iniciativa, uma decisão que nem sempre se dá em conjunto com os gestores do empreendimento social e o público beneficiado pela iniciativa apoiada. $\mathrm{O}$ encerramento prematuro de um projeto pode comprometer o alcance dos resultados inicialmente almejados, como vimos no caso Aliança Empreendedora e Cooperativa Vira Lata. Por outro lado, a crença de que os resultados em termos de promoção do desenvolvimento somente serão obtidos em médio prazo fomenta o investimento social contínuo por parte do financiador, ainda que esses resultados intermediários estejam aquém dos pretendidos, como ilustra o caso Fundo Zona Leste Sustentável.

O governo local figura como outro importante agente nos casos estudados. Prefeituras, Secretarias Municipais e Subprefeituras detêm o poder de influir no contexto econômico em que se desenvolvem as iniciativas, atuando como aliadas para a efetiva promoção do desenvolvimento social em âmbito local, ou como restritoras a esses processos de mudança. 
Tal influência é bastante evidente no caso da cooperativa de materiais recicláveis estudada, uma vez que as políticas locais de coleta e destinação de resíduos sólidos determinam a própria existência da cooperativa.

O poder público local ainda é fundamental para a implementação das políticas públicas associadas ao tipo de iniciativa realizada pelo empreendimento social. Neste contexto, muitas vezes cabe ao empreendimento social funcionar como catalisador para que os cidadãos tenham seus direitos assegurados pelo Estado. A Interação, por exemplo, propiciou a aproximação da comunidade dos Portais aos órgãos públicos responsáveis pela implementação de programas de habitação locais, além de apoiar a participação no acesso a recursos federais para a construção das moradias. O Fundo Zona Leste, por sua vez, busca capacitar os empreendedores para que rompam com a barreira da burocracia imposta pelo Estado, ampliando suas possibilidades de acesso a crédito e a programas de fomento do empreendedorismo.

Outros agentes posicionam-se no campo como facilitadores para a implementação do projeto conduzido pelo empreendimento social. É o caso dos centros educacionais, organizações da sociedade civil e lideranças sociais integrantes dos comitês que compõem o Fundo Zona Leste Sustentável. Assim como a agência bancária e os equipamentos públicos que dão apoio às atividades da Comunidade dos Portais. A constelação de agentes varia de acordo com o empreendimento social, com o tipo de iniciativa realizada e com as demandas do grupo social ou comunidade envolvida, não sendo possível inferir características comuns a partir dos casos estudados. Observa-se, apenas, que se a metodologia empregada atribui ao empreendimento social o papel de mobilizador e aglutinador de distintas pessoas e instituições no campo em que atua, aí são constituídas mais interações do que nos projetos em que o empreendimento social tem papel de executor da ação.

O capital intelectual é a força motriz para a ação dos empreendimentos sociais nos campos estudados. Ele está presente no know-how e na metodologia empregada por estes agentes em ações que visam contribuir para o desenvolvimento social dos grupos de pessoas beneficiadas pela iniciativa. Os próprios empreendedores sociais e suas equipes costumam ser os detentores do capital intelectual, posicionando-se no campo de modo a identificar oportunidades, propor alternativas de ação, construir parcerias com outros agentes e alimentar a implantação do projeto. Assim acontece com os fundadores da Interação, da Fundação Tide 
Setúbal e da Aliança Empreendedora. Embora todos esses empreendedores disponham de corpo técnico bastante qualificado em suas organizações, o caráter inovador e visionário das iniciativas estudadas, o qual sustenta o capital intelectual, está mais fortemente presente nos precursores dos empreendimentos sociais.

O capital técnico-operacional está presente nos processos de implementação dos projetos conduzidos pelos empreendimentos sociais. É mobilizado principalmente pelos parceiros que apoiam as iniciativas realizadas, por meio da combinação entre capacidade técnica e capacidade de execução de ações efetivas no campo. A interação entre diferentes agentes fomenta o compartilhamento do capital técnico-operacional e o fortalecimento do próprio empreendimento social, como ilustra o caso Fundo Zona Leste Sustentável. O capital técnicooperacional presente no campo onde aquele agente atua é mobilizado na participação de diversos parceiros em comitês que integram, estruturalmente, o próprio Fundo. Esses agentes interagem entre si e com os empreendimentos contemplados pelo Fundo, aportando capacidade técnica de diferentes tipos no processo. Ainda que com distribuições desiguais de poder e de capacidade de execução entre diferentes agentes, esta forma integrativa de ação constitui um mecanismo que visa à consolidação da iniciativa e à potencialização dos resultados.

Os grupos de pessoas beneficiadas pelas ações dos empreendimentos sociais são detentores do capital humano presente no campo. Ao participar de ações que visam transformar suas realidades, esses grupos mobilizam capacidades que permitem o desenvolvimento de potenciais, o aproveitamento de oportunidades e a realização de ações conjuntas. Nas iniciativas estudadas, a mobilização do capital humano está no cerne das ações realizadas pelos empreendimentos sociais. Todos partem da premissa de que o desenvolvimento local é promovido pela mobilização das capacidades das pessoas, cabendo ao empreendimento social desempenhar um papel de catalisador neste processo. Assim, a Interação busca fomentar e fortalecer a participação comunitária como primeiro passo para a criação de condições que levem a comunidade a ter assegurado seu direito a habitação digna. O Fundo Zona Leste Sustentável ambiciona criar cadeias de valor entre empreendimentos locais, por meio da criação de redes entre empreendedores, fornecedores e compradores, estimulando o fortalecimento da economia local. A Aliança Empreendedora visou criar e alimentar uma cultura de cooperativismo entre os trabalhadores da Vira Lata como via para o 
aperfeiçoamento da gestão da cooperativa e, consequentemente, para a conquista de melhores condições de operação, comercialização e remuneração.

Nos três casos estudados, entretanto, a mobilização deste capital humano mostrou-se desafiadora para a ação dos empreendimentos sociais. Embora presente nos campos estudados como um conjunto de capacidades relacionadas ao próprio desejo de mudança presente nas pessoas envolvidas, o capital humano mostrou-se bastante suscetível à inércia e ao individualismo que caracterizam a atitude dos diferentes grupos de pessoas beneficiadas pelas iniciativas estudadas. Seja na construção de uma gestão compartilhada, como no caso da cooperativa de reciclagem, seja no fomento da organização comunitária, caso da comunidade apoiada pela Interação, seja ainda na criação de vínculos locais de cooperação técnica, financeira e comercial, como na proposta da criação do fundo comunitário na Zona Leste de São Paulo, o capital humano mobilizado ainda não se mostrou suficiente para que estes propósitos sejam plenamente atingidos. Como resultado, as posições ocupadas por estes grupos de pessoas no campo ainda se mostra significativamente dependente do poder de articulação e mobilização dos empreendimentos sociais, dando sinais de fraqueza à medida que estes se distanciam, como observado nos três casos estudados.

O capital financeiro é fundamental para a ação dos empreendimentos sociais nos casos estudados. Sob a forma de recurso financeiro destinado às ações realizadas no campo, este capital é aportado, sobretudo, como investimento social privado por parceiros daqueles empreendimentos para os projetos realizados, como é característico nos campos onde operam as organizações sem fins lucrativos.

Do ponto de vista das iniciativas apoiadas pelos empreendimentos sociais estudados, a mobilização de capital financeiro pode ocorrer em diversos níveis e com diferentes finalidades, estando presente em todos os casos. A criação de grupos de poupança na Comunidade dos Portais torna-se um meio para a organização comunitária, e esses recursos permanecem acessíveis para os poupadores, sem qualquer mobilização adicional no campo. $\mathrm{O}$ investimento de recursos financeiros para alavancagem dos negócios de empreendedores locais, vinculado a compromissos e contrapartidas que visam fomentar a economia local, funciona no Fundo Zona Leste Sustentável como uma das formas de mobilização de capital financeiro no campo onde atua. Os recursos captados, que compõem o Fundo junto a parceiros locais, também visam à mobilização daquele capital no campo, embora ainda não 
tenha obtido resultados expressivos. Por fim, as relações comerciais estabelecidas entre a Cooperativa Vira Lata e a empresa que financiou o projeto realizado pela Aliança Empreendedora também são pautadas pela mobilização de capital financeiro. Um dos propósitos desta parceria foi, justamente, promover aperfeiçoamentos na capacidade gerencial e institucional da cooperativa para que atingisse patamares superiores de produção e remuneração na própria relação com a empresa financiadora.

A mobilização do capital político, no exercício de um poder reconhecido pelos agentes do campo, é mais evidente nos campos onde o governo local ocupa papel central na implantação de políticas que influenciam os grupos apoiados pelos empreendimentos sociais. A destinação de resíduos sólidos pela cooperativa Vira Lata, por exemplo, tem seu mercado regulado por políticas e programas municipais, os quais são influenciados pelas políticas regulatórias de âmbito federal. O projeto realizado pelo empreendimento social visou aperfeiçoar a gestão de cooperativa, o que poderia contribuir para um melhor aproveitamento de oportunidades junto a estes programas. No caso da Comunidade dos Portais, o envolvimento da Secretaria Municipal de Habitação foi decisivo para que a urbanização da área ocorresse, atingindo um dos objetivos propostos pela Interação.

São poucos os atores que mobilizaram capital operacional no campo, o qual se mostrou menos presente e menos relevante em todos os casos estudados. Como exemplo, há o apoio institucional dado pela agência bancária que abriga as contas-poupança dos grupos constituídos na Comunidade dos Portais. E o capital operacional que é mobilizado na interação entre os empreendimentos apoiados pelo Fundo Zona Leste Sustentável, o qual pode vir a embrionar cadeias de valor na região.

\subsubsection{Empreendimentos sociais orientados para o desenvolvimento social}

Os empreendedores sociais responsáveis pela criação das iniciativas estudadas compartilham características muito comuns. Mobilizados pela identificação de oportunidades para contribuir com a transformação social de um dado grupo de pessoas, buscaram desenvolver ou aplicar metodologias que concretizassem suas crenças e aspirações pessoais. Observou-se que a motivação subjacente a estas ações não foi caracterizada pela indignação com a desigualdade e a pobreza, embora este fator esteja presente. Aqueles empreendedores tiveram sua ação 
muito mais orientada pela constatação de que o grupo-alvo de sua ação detinha potencialidades e capacidades que precisavam ser mobilizadas, e o papel do empreendimento social seria o de catalisar este processo.

Ir além da proteção social e dos limites da ação estatal são fundamentos que nortearam a criação dos empreendimentos sociais estudados. A Interação identificou na metodologia de intervenção do SDI uma forma de complementar com mais eficiência a ação do poder público na área de habitação. O Fundo Zona Leste e a Aliança Empreendedora propõem estratégias de intervenção orientadas para o fomento do empreendedorismo local, como mola propulsora para a inserção de pessoas e grupos no sistema econômico vigente. Essas abordagens para as questões com as quais lidam os empreendedores sociais conferem à sua ação o caráter inovador, emancipador e pragmático já amplamente ressaltado na literatura sobre o tema (ALVORD et al, 2002; OLIVEIRA, 2004b; FISCHER, 2011). O que os casos revelam, adicionalmente, é a influência exercida pelas trajetórias individuais destes empreendedores na concepção de desenvolvimento social e no tipo de ação realizada.

Os empreendedores sociais entrevistados para este estudo têm suas trajetórias fortemente marcadas por ciclos contínuos de experimentação e aprendizagem. Nos três casos, as iniciativas estudadas são a concretização de novos patamares de compreensão sobre os problemas sociais em foco.

Ao conceber o Fundo Zona Leste Sustentável, a Fundação Tide Setúbal busca superar a filantropia que caracteriza sua atuação na região de São Miguel Paulista. Além de prever a captação de recursos junto a atores locais e de focalizar sua ação na esfera econômica, a Fundação começa a dar um passo na consolidação de um modelo de ação em que há retorno sobre o investimento, ainda que este retorno não seja integralmente financeiro. Ele pode se caracterizar pelo compromisso dos parceiros com o funcionamento do Fundo, ou pela contribuição dada pelos empreendimentos apoiados para incrementar a geração local de emprego e para criar mecanismos de sustentabilidade ambiental, por exemplo.

A aplicação da metodologia desenvolvida pela SDI foi a forma encontrada pelos fundadores da Interação para obter agilidade ao efetivar o direito de comunidades vulneráveis à habitação. Tendo trabalhado com esta questão na esfera do Estado, aqueles empreendedores compreenderam os obstáculos que se colocam à implantação de políticas efetivas para 
redução do déficit habitacional. A ação por meio da organização da sociedade civil, com uma metodologia amplamente testada, foi o salto de inovação aportado pelo empreendimento social como forma de compensar a ineficiência do governo.

A experiência com o empreendedorismo de baixa renda abriu caminho para que os jovens fundadores da Aliança Empreendedora decidissem criar e aplicar um conjunto de metodologias que dessem sustentação à visão de "fazer da economia um local para todos". Ainda que o repertório de vivências práticas deste grupo de empreendedores sociais fosse bastante limitado a projetos inicialmente desenvolvidos em âmbito acadêmico, a constante avaliação dos processos empregados os levou a rever crenças e princípios de ação, propondo novas abordagens em seu campo de atuação. A metodologia empregada junto às cooperativas de reciclagem, por exemplo, foi adaptada às características presentes na iniciativa desenvolvida em São Paulo, refletindo uma concepção mais realista das potencialidades e limitações da ação empreendida.

Os pressupostos subjacentes às atividades realizadas pelos empreendimentos sociais estudados são reflexos dos ciclos de aprendizagem vivenciados pelos empreendedores sociais e enfatizam diferentes ângulos do desenvolvimento local. Com alcance mais ambicioso, a missão da Aliança Empreendedora está orientada para a promoção do desenvolvimento econômico e social por meio do empreendedorismo individual:

Unir forças e viabilizar acessos para que pessoas e comunidades de baixa renda possam ser empreendedoras, promovendo a inclusão e o desenvolvimento econômico e social. (ALIANÇA EMPREENDEDORA, 2012)

Sem fazer menção a uma perspectiva mais ampla de desenvolvimento, a Interação tem sua missão bastante focalizada na garantia de direitos de cidadania e moradia:

Contribuir para que as comunidades em assentamentos precários no Brasil conquistem seus direitos de cidadania e moradia por meio da organização comunitária e reconhecimento de seu potencial transformador e multiplicador. (INTERAÇÃO, 2012) 
A preocupação com o desenvolvimento vai surgir apenas no desenho dos objetivos pretendidos pela Interação, sendo um deles exclusivamente voltado para a "promoção do desenvolvimento econômico, social e combate à pobreza.” (INTERAÇÃO, 2012)

A missão do Fundo Zona Leste Sustentável, por sua vez, foi desenhada a partir de uma perspectiva orientada para o fomento de iniciativas produtivas locais como meio para geração de trabalho e renda:

Canalizar recursos de pessoas físicas e jurídicas com interesse em contribuir para a região e aplicálos de forma monitorada em iniciativas produtivas locais, de modo a permitir que elas atinjam competitividade no mercado e gerem oportunidades duradouras de trabalho e renda no território. (FUNDO ZONA LESTE SUSTENTÁVEL, 2011)

Ainda que as missões dos empreendimentos sociais enfatizem diferentes objetivos, os meios expressos nestas declarações assemelham-se em dois aspectos: a ênfase no protagonismo das iniciativas apoiadas e a soma de esforços dos atores envolvidos. Esses elementos sinalizam a existência de uma crença comum aos empreendedores estudados, que é a vinculação dos processos de desenvolvimento local à mobilização de recursos humanos, materiais e financeiros existentes nas localidades em que se desenvolvem as iniciativas. Desta forma, os empreendimentos sociais colocam-se expressamente como agentes capazes de influenciar o contexto, oferecendo condições para que as pessoas ou grupos-alvo da ação assumam papel ativo no seu próprio desenvolvimento, o qual ocorrerá por via da articulação com sistemas e atores relevantes no campo onde atuam.

As concepções de desenvolvimento adotadas pelos três empreendimentos estudados fundamentam-se em pressupostos de desenvolvimento local: a transformação social como processo de construção coletiva; a mobilização de potencialidades e recursos locais; o protagonismo da comunidade ou grupo de pessoas. (BROSE, 2005; HADDAD, 2004; LOURENÇO, 2003).

A perspectiva do desenvolvimento local é patente na iniciativa realizada pela Interação junto à Comunidade dos Portais. A participação ativa da comunidade desde o planejamento das ações, incluindo o conhecimento e o diagnóstico de sua situação, é característica deste processo (GOMES, 2005). Também se destaca, no caso, o empoderamento das comunidades e 
a promoção da democracia direta, associados a negociações entre os atores envolvidos no processo de desenvolvimento, como observa Sachs (2004).

Por outro ângulo, o fomento ao cooperativismo e ao empreendedorismo - os quais caracterizam as iniciativas da Aliança Empreendedora e do Fundo Zona Leste Sustentável -é um processo que guarda algumas características dos conceitos de economia solidária. Nesse sentido, destaca-se o incentivo a formas de produção orientadas para a sobrevivência e para a reciprocidade, cujos resultados beneficiam um grupo de pessoas, influenciando positivamente os relacionamentos entre os atores envolvidos direta ou indiretamente. (SINGER, 2004; FRANÇA FILHO; LAVILLE, 2004)

A ampliação de capacidades por meio da remoção de condições que causam privação de liberdades econômicas, sociais e políticas - como propõe Sen (2000) para os processos de desenvolvimento - é a diretriz expressamente adotada pela Fundação Tide Setúbal em suas ações junto a comunidades da Zona Leste. Esse princípio inspirou a criação do Fundo Zona Leste Sustentável como um meio para trabalhar as potencialidades existentes no território. (FUNDAÇÃO TIDE SETÚBAL; GIFE, 2010)

As concepções de desenvolvimento adotadas pelos empreendimentos sociais estudados influenciam as disposições presentes nos campos onde operam as iniciativas apoiadas. Tanto o Fundo Zona Leste Sustentável quanto a Interação foram responsáveis por mudar crenças subjacentes à forma como as pessoas se posicionavam no campo. Com isso, criaram oportunidades para que se estabelecessem novas formas de relação entre os agentes, facilitando ou viabilizando o acesso a recursos que garantiram a melhoria em indicadores de desenvolvimento social em âmbito local.

A Interação propiciou um diálogo legítimo entre a Comunidade dos Portais e a Secretaria Municipal de Habitação, o que foi fundamental para que aquelas pessoas deixassem de se sentir manipuladas e negligenciadas. Construindo um novo patamar de negociação, representantes da comunidade passaram a ser bem recebidos pelo poder público, tendo suas reivindicações ouvidas e acatadas, o que representou o grande passo dado para a urbanização da favela e a conquista de moradias dignas e definitivas. Essas conquistas levaram um grupo de pessoas, representantes da comunidade local, a abandonarem atitudes passivas e apáticas 
frente à sua realidade social, experimentando condutas orientadas para a gestão democrática e participativa. A consolidação destas novas disposições, entretanto, enfrenta resistências e parece enfraquecer quando a presença do empreendimento social se reduz.

O Fundo Zona Leste Sustentável contribuiu decisivamente para que os negócios por ele apoiados deixassem de operar no campo de maneira informal e pouco profissionalizada. Oferecendo formação técnica e assessoria especializada, convenceu as pessoas envolvidas a buscarem um novo posicionamento para os produtos e serviços oferecidos por seus empreendimentos. Esse processo resultou na adoção de novas condutas, pautadas pela adesão à legislação comercial vigente e pela implantação de planos de negócios estrategicamente fundamentados. Ainda que essas novas disposições enfrentem resistências pontuais, os benefícios identificados pelos empreendedores parecem ser suficientes para que o posicionamento dos agentes se consolide em patamar mais profissionalizado que o anterior. A própria interação entre os empreendimentos contribui para este processo, na medida em que cria uma rede de apoio mútuo.

O Fundo Zona Leste Sustentável também ambiciona mudar disposições entre outros agentes presentes no campo - os parceiros animados a participar dos Comitês que compõem estruturalmente o Fundo. Fomentando a interação entre agentes privados, públicos e oriundos da sociedade civil, o Fundo estimula a adoção de condutas voltadas para a colaboração, para a soma de competências e para a responsabilização dos distintos agentes frente à promoção do desenvolvimento local sustentado. Entre os parceiros, a colaboração já se vê presente em variados graus. Mas ainda não se observa a consolidação de novas disposições no campo, sobretudo no que diz respeito à efetiva distribuição de papéis e responsabilidades entre a Fundação Tide Setúbal e os demais agentes frente ao próprio Fundo.

A resistência à adoção de novas condutas que levem a mudanças em disposições nos campos está presente nos três casos estudados. Os agentes envolvidos, seja o grupo-alvo da ação, sejam parceiros e apoiadores, reconhecem a existência de oportunidades para a construção de processos de mudança orientados para o desenvolvimento local. Entretanto o sistema de disposições presente no campo ou o habitus, conforme acepção de Bourdieu, impõe regularidades que não são regidas pela razão e não são produto de estratégias conscientes (BOURDIEU, 1990; MICELI, 2007). Esse sistema confere certa rigidez à conduta dos 
agentes no campo, o que contribui para que resistências se manifestem, mesmo quando a mudança é compreendida e desejada.

As oficinas de capacitação e a assessoria permanente oferecidas pela Aliança Empreendedora aos trabalhadores da cooperativa Vira Lata não resultaram em mudanças visíveis nas disposições presentes no campo. A relutância à adoção de novas condutas, presente entre os trabalhadores de nível operacional e de nível administrativo da cooperativa, fez com que muito pouco do que foi proposto na ação da Aliança Empreendedora fosse compreendido e aproveitado na cooperativa. A vulnerabilidade social que caracteriza o grupo-alvo da ação parece tornar o conjunto de disposições presentes ainda mais rígido que nos outros casos. Além disso, os agentes ocupam posições fixas no campo, com interações pautadas pelas relações comerciais que se estabelecem. Diferentemente da experiência que o empreendimento social teve em Curitiba, onde implantou com sucesso a metodologia para desenvolvimento das cooperativas de catadores, em São Paulo os fatores elencados, dentre outros, parecem ter levado a um recrudescimento das objeções à mudança.

\subsubsection{Fatores que influenciam a promoção do desenvolvimento social}

Os empreendimentos sociais criam diferentes estruturas e condições para atingir seus objetivos estratégicos. A criatividade com que seus empreendedores mobilizam, integram e aplicam os recursos materiais, humanos e financeiros confere variadas matrizes para a operação dessas formas organizativas. Dentro de tal diversidade, algumas características já discutidas na literatura sobre o tema parecem comuns à maioria dos empreendimentos sociais, destacando-se o foco na criação de valor social, inovação, pragmatismo, efetividade de resultados, construção de parcerias e alianças. (FISCHER, 2011; SEKN, 2006; NICHOLLS, 2006; OLIVEIRA, 2004b; DEES, 2001; JOHNSON, 2000)

Algumas características particulares influenciam o modo como os empreendimentos sociais estudados contribuem, por meio de seus projetos, para a promoção do desenvolvimento social. Esses fatores são: motivação do público-alvo, metodologia de intervenção social, escolha das iniciativas apoiadas, legitimidade local, parcerias e redes de relacionamento, além de efetividade de resultados. 
As iniciativas realizadas pelos empreendimentos sociais estudados implicam na mobilização das pessoas ou grupos-alvo da ação: trabalhadores cooperados à Vira Lata, moradores da Comunidade dos Portais e empreendedores contemplados pelo Fundo Zona Leste Sustentável. A motivação dessas pessoas para participarem de forma ativa das iniciativas está bastante relacionada à convergência de interesses entre a proposta do empreendimento social e as necessidades ou aspirações individuais. Em alguns casos, este encontro de interesses adquire tal magnitude que as aspirações do empreendimento social e das pessoas beneficiadas tornamse únicas, num processo sinérgico de motivação. Em outros casos, o benefício proposto pelo empreendimento social é tido como uma boa oportunidade, cujo valor atribuído é suficiente para que as pessoas sintam-se estimuladas a participar, mas sem que exista efetivo comprometimento com o processo e seus objetivos.

Os casos estudados exemplificam as diferentes formas de motivação e envolvimento dos grupos-alvo com as iniciativas propostas pelos empreendimentos sociais. Por meio de estratégias de convencimento, a Interação foi capaz de fomentar a participação de dezenas de moradores da Comunidade dos Portais. Motivados pelo desejado acesso ao poder público e pela crença na possibilidade de transformação de sua realidade, muitos moradores engajaramse na proposta do empreendimento social, apropriando-se das ações e objetivos propostos.

De forma diferente, as capacitações oferecidas pela Aliança Empreendedora e o processo de construção de planos de ação constituíram boas oportunidades para o aperfeiçoamento da operação e da gestão da Vira Lata. Seus trabalhadores sentiram-se motivados por beneficiarem-se, em diferentes graus, das breves capacitações oferecidas e por constatarem a melhoria nos resultados da cooperativa. Mas, ao final do projeto, não estavam suficientemente envolvidos para buscar sua continuidade ou ampliar os benefícios obtidos até então.

Entre os empreendedores contemplados pelo Fundo Zona Leste Sustentável, diferentes graus de motivação e engajamento são observados. O principal fator de participação é o acesso a recursos financeiros para alavancar o negócio, mas a proposta do Fundo excede isso, ao propor a estes empreendedores que criem redes de colaboração e de geração de valor. Enquanto alguns compartilham destes ideais e buscam, dentro de suas limitações, dar a contrapartida comercial e social solicitada pelo Fundo, outros se mostram menos motivados a ir além da frequência nos programas de capacitação e da aplicação do plano de negócios proporcionado pelo empreendimento social. 
Os empreendimentos sociais atingem seus objetivos por meio da aplicação de metodologias conceitualmente fundamentadas, sistematizadas e continuamente submetidas a testes e ajustes. Essa implantação requer adaptação ao contexto e às demandas próprias de cada grupo de pessoas que será beneficiado com sua aplicação, com vistas a garantir sua aderência e eficiência. Tal conjunto de cuidados no desenvolvimento e na implantação de metodologias consistentes caracteriza a estratégia de ação adotada pelos três empreendimentos sociais estudados, em suas iniciativas de promoção do desenvolvimento local.

A metodologia empregada pela Interação fundamenta-se no conhecimento e na experiência detidos pelo SDI, tendo sido amplamente introduzida em diversos países. Junto à cooperativa Vira Lata, a Interação aplicou uma adaptação de parte da metodologia ECO-Cidadão, implantada com sucesso junto a cooperativas de reciclagem localizadas em Curitiba. E o Fundo Zona Leste Sustentável é, em si, uma experiência de construção de metodologia para desenvolvimento local, assentada sobre ampla pesquisa e troca de experiências em implantação de fundações comunitárias.

Duas características são comuns às metodologias aplicadas pelos três empreendimentos sociais estudados: a oferta de assessoria técnica e de programas de capacitação aos participantes. É desta forma que os empreendimentos transferem know-how e fortalecem as competências necessárias para a obtenção dos resultados almejados. O apoio dado pela Aliança Empreendedora foi centrado nesses dois aspectos, os quais figuram entre as principais características da metodologia desenvolvida pelo empreendimento social para o trabalho com cooperativas. A Interação tem na assessoria técnica um dos alicerces de suas estratégias de mobilização e organização comunitária. A educação financeira vem a complementar sua intervenção, sobretudo na criação dos grupos de poupança. O Fundo Zona Leste Sustentável dispõe de equipe técnica responsável por monitorar e apoiar os empreendimentos contemplados em cada edição, com foco na utilização dos recursos, na formalização jurídica e na implantação dos planos de negócios. Dispõe também de apoio especializado de alunos e professores da UNICSUL. Em parceria com o SEBRAE e, mais recentemente, com o SENAC, oferece programas de formação e capacitação em empreendedorismo, plano de negócios e cursos técnicos. 
Em suas metodologias, Interação e Fundo Zona Leste Sustentável também contemplam aspectos de mobilização de atores locais, o que está bastante alinhado com as abordagens de desenvolvimento local empregadas por estes empreendimentos sociais. A Interação tem seu foco na mobilização de membros da comunidade, na identificação e preparação de lideranças locais e na construção de pontes com outros atores relevantes para a intervenção social que realiza, como governos locais e programas federais. O Fundo Zona Leste Sustentável focaliza a articulação de diferentes setores da comunidade, visando estabelecer parcerias que deem sustentação institucional e financeira para o Fundo e suas ações de fomento da economia local.

Em linha com as premissas que sustentam as metodologias aplicadas pelos empreendimentos sociais, há a aplicação de critérios mais ou menos sistematizados para a escolha das iniciativas que serão apoiadas. Em geral, procura-se identificar sinais de potencialidade para a mudança no território: verificar se há indícios de que as pessoas compartilham uma identidade, bem como se existem outros atores e projetos que possam prejudicar a implantação da iniciativa.

Diferentemente dos demais empreendimentos estudados, o Fundo Zona Leste Sustentável conta com critérios formais que parametrizam a escolha dos negócios que receberão o aporte de recursos financeiros a cada edição. Dentre os candidatos que atendem aos critérios propostos na fase de edital, são escolhidos aqueles que, de acordo com o Comitê Programático do Fundo, apresentam características mais alinhadas com os objetivos do programa. Elas incluem o espectro de possibilidades de participação em cadeias de valor, a oferta de produtos ou serviços que potencializem a dinâmica da economia local e a presença de características pessoais que possam ser associadas ao empreendedorismo.

Interação e Aliança Empreendedora fazem suas opções com base na observação feita pelos empreendedores sociais sobre as oportunidades de intervenção que se apresentam. Embora ambos priorizem os critérios descritos buscando, com aplicação destes parâmetros, alguma garantia de que os objetivos dos projetos serão alcançados, o projeto realizado pela Aliança Empreendedora junto à Cooperativa Vira Lata foi definido pelo seu financiador. Neste caso, a inexistência de muitas das condições buscadas pela Aliança em suas intervenções pode ter contribuído para o baixo desempenho da iniciativa. 
Outro fator que influencia a forma como o empreendimento social cria condições para contribuir com o desenvolvimento local é a obtenção de legitimidade frente à comunidade ou grupo de pessoas que será beneficiado pela iniciativa. A legitimidade autoriza o empreendimento a implantar sua própria metodologia de trabalho e influi positivamente na motivação das pessoas para participarem da iniciativa. Ela é obtida pelo reconhecimento do empreendimento e de sua equipe de técnicos como detentores de know-how e experiência no tema, pela construção de relações de empatia e confiança, pela transparência e ausência de interesses pessoais ou políticos com a iniciativa, e pelo aval dado por atores locais para a continuidade da ação.

A Interação preocupou-se, desde seus primeiros contatos com a Comunidade dos Portais, em sinalizar que não haveria promessas, compromissos de longo prazo e outros interesses a não ser a aplicação de uma metodologia já reconhecida e voltada, especificamente, para a promoção e garantia dos direitos de moradia. Sua equipe técnica foi habilidosa em levar conhecimento à comunidade de forma empática e construtiva. A Fundação Tide Setúbal, por sua vez, já desfrutava de legitimidade junto à comunidade de São Miguel, em sua larga experiência na promoção de projetos sociais na região. Essa legitimidade foi reforçada pelo apoio recebido por outros reconhecidos atores locais, como a Universidade Cruzeiro do Sul, a Associação Comercial e lideranças comunitárias. A transparência, inclusive na gestão dos recursos, também foi enfatizada na criação do Fundo Zona Leste Sustentável como um fator de governança que conferiu legitimidade à iniciativa. A apresentação da Aliança Empreendedora à Cooperativa Vira Lata por um forte parceiro comercial desta última contribuiu para que gestores e trabalhadores confiassem no projeto que seria realizado. Além disso, a grande experiência do empreendimento social com cooperativas, principalmente as de reciclagem, respaldou sua legitimação.

Por fim, a construção de parcerias e de redes de relacionamentos foi um dos principais métodos de ação empregados por dois dos três empreendimentos estudados. As parcerias visam obter complementaridade de competências, distribuição de papeis e atribuição de responsabilidades entre diferentes atores presentes nos campos onde são desenvolvidas as iniciativas de promoção do desenvolvimento local. A criação de redes entre os grupos apoiados pelos empreendimentos sociais é apresentada como premissa para o fortalecimento destes mesmos atores. 
A metodologia implantada pela Interação prevê a realização de intercâmbios para o compartilhamento de experiências, com vistas a fomentar a criação das redes de relacionamentos. O Fundo Zona Leste Sustentável almeja promover a criação de cadeias de valor entre os diversos negócios apoiados, como forma de dinamizar a economia local. Além disso, ambos os empreendimentos usaram, ao longo de suas intervenções, redes de contatos pessoais que contribuíram para atingir objetivos específicos dos projetos, como o acesso à Secretaria Municipal de Habitação de Osasco e os recursos financeiros para a primeira edição do Fundo.

Os casos estudados sinalizam a existência de diversos fatores que contribuem para que os empreendimentos sociais sejam efetivos em suas estratégias de transformação social e desenvolvimento local. Mas, simultaneamente, revelam algumas limitações apresentadas pelos empreendimentos e pelas metodologias na busca de concretizar seus objetivos, sobretudo na sustentação do compromisso das pessoas beneficiadas pelo projeto com a continuidade dos processos de desenvolvimento local.

A mobilização e a organização comunitária, seja em um território, seja de um grupo de pessoas que partilham condições socioeconômicas comuns, são processos marcados por resistências e retrocessos. Não basta o desejo das pessoas ir ao encontro das propostas trazidas pelos empreendimentos sociais para que elas mantenham o compromisso com uma participação contínua. Ainda que os resultados concretos de experiências anteriores e de benefícios iniciais sejam fortes motivadores para atrair a atenção num primeiro momento, ao longo do tempo, a mobilização perde sua força, demandando constante esforço de manutenção. Esse esforço envolve recursos humanos e financeiros que os empreendimentos sociais não têm condições de investir por muito tempo, ou mesmo não deveriam investir, tendo em vista o risco de criarem relações de dependência e subordinação.

Os três casos estudados enfrentam o desafio de criar e manter a participação social como um dos motes de fortalecimento do capital social local e do protagonismo comunitário, tendo por objetivo a melhoria contínua da qualidade de vida do grupo de pessoas que participa das iniciativas. Embora seja cedo para avaliar, visto que o empreendimento é ainda incipiente, o Fundo Zona Leste Sustentável também tem tido baixo grau de participação efetiva de atores locais, mesmo daqueles cujos empreendimentos estão sendo apoiados, quando propõe a 
construção de arranjos produtivos e de colaborações intersetoriais. A Interação logrou êxito na constituição de grupos de poupança e na organização comunitária em prol da urbanização da favela Portais, mas a mobilização perdeu sua força, uma vez que os objetivos iniciais foram atingidos. Os trabalhadores da Cooperativa Vira Lata foram capacitados e assessorados para implantarem um modelo de autogestão baseado nos princípios da economia solidária, mas continuam produzindo de forma individualizada, com baixa participação nos processos de gestão organizacional.

Nos casos estudados, para a maioria dos participantes, a falta de objetivos comuns, potencialmente motivadores, e a predominância de traços culturais que colocam atitudes individualistas acima dos valores coletivos são os principais restritores aos processos de criação e fortalecimento da participação comunitária. Os contextos em que se inserem as comunidades e grupos beneficiados pelos empreendimentos sociais influenciam e reforçam essas disposições. Como característica que perpassa gerações, a ausência de oportunidades sociais e econômicas leva a uma constante busca individual - muitas vezes solitária - para obter, no curto prazo, soluções de sobrevivência e melhoria das condições familiares e da qualidade de vida. Ainda que a maior parte das pessoas se sinta motivada a contribuir para que os processos de participação social tragam benefícios que serão compartilhados por todos, ao longo do tempo, apenas pequenos grupos ou poucas lideranças locais assumem a responsabilidade por alimentar a continuidade da organização comunitária.

\subsubsection{Resultados para o desenvolvimento social}

Operando em prol da melhoria das condições de vida dos grupos que apoiam, os empreendimentos sociais estudados têm foco bem definido para os resultados pretendidos em cada localidade. A geração de oportunidades de trabalho e renda por via da educação, da qualificação profissional, da melhoria nos processos de trabalho e da autonomia na condução dos negócios são objetivos almejados pela Aliança Empreendedora e pelo Fundo Zona Leste Sustentável respectivamente para os trabalhadores cooperados e empreendedores que apoiam.

Por meio de novas formas e metodologias de participação e de organização social, o empoderamento e o protagonismo das pessoas, comunidades e atores sociais locais são resultados pretendidos pela Interação e pelo Fundo Zona Leste Sustentável. Numa perspectiva 
territorial, os dois empreendimentos buscam qualificar a participação dos atores, fomentando o compromisso social e individual com a melhoria da qualidade de vida, o fortalecimento da solidariedade e a conscientização sobre o papel social e político das diferentes parcelas da sociedade civil. A Interação, obedecendo à especificidade de seu foco de atuação, visa propiciar condições para que a comunidade tenha acesso a moradia regularizada e digna.

Segundo relatos dos participantes entrevistados, dentre os indicadores de resultados na esfera da riqueza material a partir do desenvolvimento social, as iniciativas realizadas pelos três empreendimentos sociais propiciaram aumento da renda, embora em nenhum dos três casos haja dados quantitativos identificados que permitam estimar e comprovar essa assertiva. Diferentes vias levaram a este resultado, conforme o tipo de foco e ação de cada empreendimento social: o aumento da produção na Cooperativa Vira Lata, o acesso a novas oportunidades de negócios pelos empreendimentos da Zona Leste e o acesso a emprego formal facilitado pela comprovação de residência pelos moradores da extinta favela Portais.

Ainda na esfera da riqueza material, o acesso a crédito foi um resultado apontado pelos moradores da Comunidade dos Portais e pelos empreendedores apoiados pelo Fundo Zona Leste Sustentável. O acesso à regularização do endereço de moradia, no primeiro caso, e do funcionamento dos empreendimentos, no segundo caso, criaram condições para a inserção destas pessoas no sistema formal de relações econômicas. Tornaram-se aceitos como clientes por agentes bancários, comerciantes e fornecedores, podendo exercer papeis sociais aos quais não tinham acesso quando não possuíam o reconhecimento que decorre da regularização de documentos.

Com aumento na renda e acesso a crédito, os grupos beneficiados pelas iniciativas estudadas adquiriram condições para a quitação de dívidas, além de aquisição de equipamentos eletrônicos, utilidades domésticas e outros bens para suas casas e famílias. Estes aspectos também sinalizam a melhoria nos indicadores de desenvolvimento social sob a ótica da produção de riqueza material.

Os indicadores de resultados na esfera de bem-estar social divergem entre os casos estudados, de acordo com o grau de vulnerabilidade que caracteriza cada grupo social beneficiado pelas diferentes iniciativas. 
Os empreendedores apoiados pelo Fundo Zona Leste Sustentável que foram entrevistados para este estudo desfrutavam de condições adequadas de acesso a saúde, educação e moradia, por exemplo, mesmo antes de sua participação na iniciativa. Assim, não foram observadas mudanças na esfera do bem-estar social para este grupo. É possível, entretanto, que os trabalhadores das duas cooperativas de reciclagem apoiadas pelo Fundo tenham obtido melhorias nesta esfera, pois é viável inferir que constituam um grupo com condições socioeconômicas menos favoráveis que as dos demais empreendedores apoiados por esta iniciativa.

Os trabalhadores da Cooperativa Vira Lata mencionam o acesso a capacitação profissional como um resultado positivo direto da atuação da Aliança Empreendedora, tornando-o um indicador de melhoria na esfera do bem-estar social. O aumento da renda também propiciou resultados nesta esfera, como o acesso a bens de consumo e a evolução em suas condições de moradia. Mas é a garantia de sobrevivência, por meio do acesso a trabalho digno para pessoas de diferentes origens, gêneros e idades, que se destaca entre os indicadores de bem-estar social para este grupo, caracterizado por condições de elevada vulnerabilidade social.

Os moradores da Comunidade dos Portais constituem um grupo que compartilha desse alto grau de vulnerabilidade social. A urbanização da favela e a melhoria nas condições físicas de moradia, segurança e saneamento são resultados obtidos com a iniciativa empreendida pela Interação e sinalizam melhorias nos indicadores de bem-estar social. A conscientização política e o aumento da autoestima, ainda que sejam resultados pouco tangíveis, são observados na fala dos moradores entrevistados e contribuíram indiretamente para mudanças nos níveis de escolaridade deste grupo, com a busca de conhecimento via educação formal e complementar. A instalação de equipamentos públicos na própria comunidade, como escola, Centro de Inclusão Digital e Casa de Cultura contribuíram para facilitar o acesso da comunidade a educação formal e a cultura.

A esfera do empoderamento contempla os indicadores de resultados que sofreram menos influência da ação dos empreendimentos sociais estudados. Em dois dos três casos, não foram citadas pelos entrevistados quaisquer mudanças na forma como as pessoas exercem a cidadania e a participação social, assim como na construção do capital social. 
O projeto realizado pela Interação apresenta indicadores de resultados no empoderamento de grupos de pessoas da Comunidade dos Portais, com reflexos em toda a comunidade, como detalhado na descrição deste caso. Como efetivo exercício da cidadania, foi obtido acesso ao governo local, a recursos do governo federal, a programas municipais de proteção e promoção da saúde, a equipamentos de educação, cultura e lazer. Também é possível observar que o capital social foi fortalecido, embora essas evidências sejam restritas ao pequeno grupo que tem dado continuidade aos processos de organização comunitária.

Um dos empreendimentos apoiados pelo Fundo Zona Leste Sustentável, por também ser de natureza social, apresenta indicadores de resultados na esfera do empoderamento, como o acesso a programas e equipamentos públicos e o fortalecimento do capital social na comunidade onde opera. Neste caso, os recursos aportados pelo Fundo contribuíram para a melhoria destes indicadores, mas não de maneira direta nem exclusiva. As melhorias propiciadas por tal apoio somam-se às diversas frentes de atuação do empreendimento e, em seu conjunto, estas ações resultam em mudanças que constituem seus próprios objetivos. Esta exceção ressalta o potencial que os empreendimentos sociais detêm para atuar conjuntamente e, de forma sinérgica, ampliar a abrangência dos resultados obtidos em suas frentes de ação.

Nos três casos estudados, os indicadores de resultados obtidos sinalizam que os empreendimentos sociais contribuem de diferentes maneiras para a promoção do desenvolvimento social em âmbito local. $O$ alinhamento entre as concepções de desenvolvimento adotadas, as metodologias empregadas e os resultados pretendidos é um importante fator para que estes resultados sejam, de fato, obtidos. O reconhecimento das limitações do próprio empreendimento, assim como daquelas inerentes às características de cada comunidade ou grupo de pessoas beneficiados pelos projetos realizados, também deve ser levado em consideração, pois influencia a forma como o empreendimento social aplicará sua metodologia e o tipo de resultados que obterá.

De modo geral, os resultados pretendidos pelos empreendimentos sociais para as iniciativas estudadas foram obtidos, em maior ou menor grau de dificuldade e de abrangência. A Interação alcançou resultados nas três categorias de indicadores de desenvolvimento adotadas neste estudo: empoderamento, riqueza material e bem-estar social. A Aliança Empreendedora obteve os resultados pretendidos em termos de melhorias nos indicadores de riqueza material e bem-estar social, embora sua intervenção tenha tido curta duração e tenha sido 
negativamente impactada por fatores contextuais, sobretudo a falta de transparência na gestão da cooperativa que visava fortalecer. Em sua primeira edição, o Fundo Zona Leste Sustentável atingiu resultados na esfera da riqueza material. O Fundo prevê que os resultados almejados no empoderamento dos atores locais sejam obtidos ao longo das próximas edições, pois o próprio empreendimento ainda está em fase de estruturação, assim como de aperfeiçoamento da sua metodologia. 


\section{CONSIDERAÇÕES FINAIS}

\subsection{Conclusões}

O empreendedorismo social contribui para a promoção do desenvolvimento social? Dentro do alcance e dos limites deste estudo, é possível afirmar que sim. Contribuições de empreendimentos sociais para a melhoria de indicadores de desenvolvimento social em nível local foram evidenciadas nos três casos pesquisados para este estudo. Contudo, tais resultados são bastante limitados a melhorias na qualidade de vida pessoal e familiar dos participantes nas iniciativas desenvolvidas pelos empreendimentos sociais. Persiste o desafio de obter resultados mais efetivos em termos de desenvolvimento local e de influência sobre o contexto socioeconômico mais amplo. Influenciar políticas públicas regionais ou nacionais, ou promover efetivas transformações socioeconômicas num dado território, por exemplo, não foram resultados observados nos casos estudados nesta pesquisa.

Neste estudo, os empreendimentos sociais foram identificados como agentes que mobilizam know-how e metodologias próprias e aliam-se a outros agentes detentores de distintos capitais, os quais constituem fontes de poder para beneficiar determinados grupos de pessoas, comunidades ou territórios. Essas redes de relações objetivas caracterizam campos, conforme acepção de Bourdieu (1990). Nesses campos, os empreendimentos sociais podem ser agentes relevantes, especialmente se forem constituídos como expressão dos desejos e anseios da sociedade civil, como meios de inovação social e como catalisadores para o fortalecimento do capital social, por exemplo.

As disposições que determinam a conduta dos agentes no campo onde os empreendimentos sociais operam são constituídas historicamente, integrando experiências passadas que estabelecem uma matriz de percepções, representações e ações dos agentes que interagem no campo. Ao se inserir neste contexto como um agente transformador, os gestores dos empreendimentos sociais e de seus projetos se vêem obrigados a lidar com as disposições existentes, beneficiando-se daquelas favoráveis aos objetivos do empreendimento social e contribuindo para influenciar, ou mesmo alterar disposições que geram barreiras e resistências 
à sua ação. Apostam, portanto, na flexibilidade inerente ao habitus, a qual possibilita inovação e transformação social, como observa Miceli (2007).

Como já bastante ressaltado pela literatura que versa sobre a centralidade das características pessoais do empreendedor social, o estudo realizado evidencia que o fundador, que também é o idealizador dos empreendimentos e dos projetos por ele desenvolvidos, de fato é vital para a execução dos projetos e consecução de seus objetivos. As características pessoais dos empreendedores que estão associadas ao êxito na implantação das iniciativas estudadas são as mesmas sintetizadas por Oliveira (2004b): criatividade, determinação, foco na inovação social, pragmatismo aliado a habilidades profissionais, criação de parcerias e alianças estratégicas, motivação orientada para a melhoria na vida das pessoas, busca de mudanças de longo alcance e desenvolvimento de iniciativas que visam emancipar as pessoas.

Os empreendimentos sociais, na condição de formas organizacionais, tendem a ser fluidos. Adquirem variados formatos conforme o tipo de projeto em curso. De fato, uma característica marcante do empreendedor social é sua capacidade de fazer diferentes combinações de recursos humanos, materiais, estruturais e financeiros para atingir os objetivos almejados em cada frente de trabalho. Empreendimentos sociais não se estruturam em grandes escritórios físicos, em hierarquias e processos de gestão organizacional. Ao contrário, a flexibilidade que os caracteriza parece ser fundamental para que o empreendedor social consiga otimizar recursos e mobilizar competências de forma inovadora e ágil.

Por sua natureza, que entrelaça as dimensões política, econômica e social, os empreendimentos sociais teriam vocação para estreitar relações de colaboração entre diferentes atores, resultando idealmente numa simbiose do desempenho dos atores aliados. Estudos realizados pela Social Enterprise Knowledge Network (SEKN, 2006) demonstram que tal capacidade é um dos fatores distintivos deste tipo de iniciativa. O estudo realizado nesta tese revela que a colaboração intersetorial é almejada pelos empreendimentos sociais, sobretudo porque constitui um meio para que seus objetivos sejam atingidos. De fato, as alianças mostraram-se necessárias para que os projetos desenvolvidos pelos empreendimentos sociais tivessem sua implantação viabilizada e seus objetivos concretizados. Entretanto, tais colaborações não foram além de um caráter meramente instrumental. Os agentes mais poderosos, ou que exerceram influência decisiva na implantação do projeto, foram o próprio 
empreendimento social, o grupo social a ser beneficiado, os agentes financiadores e o poder público local.

Para além da lógica da colaboração que regeria as interações estabelecidas entre os agentes relevantes no campo, a análise da natureza e das formas de ação dos empreendimentos sociais revela sua configuração como forças que se opõem ao Estado ou se resguardam de sua influência política, visando garantir sua autonomia de ação e de gestão. Esses gestores buscam e estabelecem as alianças necessárias com instâncias governamentais para poderem operar com legitimidade. Mas pensam e agem como agentes autônomos no campo, detentores de qualidades diferenciadoras, como: ter soluções mais efetivas para os problemas sociais, ter maior poder convocatório e de construção de confiança com a sociedade civil. Entretanto, cabe questionar em que medida o distanciamento que os empreendimentos sociais mantêm do Estado pode constituir uma barreira ao desenvolvimento social como promoção de mudanças sistêmicas no campo das políticas econômicas, sociais e ambientais, considerando que estas seriam, de fato, responsáveis pela desigualdade no acesso a recursos, poder e oportunidades.

Sachs (2004) observa que o processo de empoderamento das comunidades e a promoção da democracia direta são fundamentais para políticas de desenvolvimento e pode tornar-se um novo paradigma de economias mistas baseadas no diálogo, nas negociações e nos contratos entre os diferentes atores envolvidos com o desenvolvimento. As iniciativas dos empreendimentos sociais se inserem neste contexto, visando fortalecer a organização comunitária e influir nos processos de geração de valor social através da inovação e da gestão. Por meio de diversificados projetos e frentes de ação, os empreendedores sociais visam combater algumas das falácias que se consolidaram na América Latina e reforçam estruturalmente a pobreza, como aquelas identificadas por Kliksberg (2003). As iniciativas realizadas pelos empreendedores sociais visam restaurar a credibilidade na força da sociedade civil, fortalecer a participação popular, solucionar problemas éticos e de governança, assim como enfraquecer os impactos da desesperança frente a esse jogo de forças, contribuindo para a criação de bases populares para remoção da pobreza.

Conceitualmente, este estudo se baseou no pressuposto elaborado por Sen (2000) de que a pobreza é constituída pela privação de capacidades do indivíduo, o que impede que as pessoas desfrutem de liberdade para terem o tipo de vida que desejam. Nesse sentido, a renda não é o 
indicador único que mensura a condição socioeconômica da pessoa, mas o meio pelo qual ela detém ou não as capacidades para viver como cidadã livre. Agrega-se a essa visão o pensamento de Sachs (2004), para quem o acesso a trabalho decente, através do emprego ou do autoemprego, é central numa estratégia endógena de desenvolvimento, pois influencia a distribuição primária de renda. Haveria, desta forma, contribuição dos empreendimentos sociais para a ampliação das liberdades individuais, considerando que foi justamente a melhoria nos níveis de renda e no acesso ao trabalho o resultado mais visível, frequente e persistente verificado nos casos estudados.

A teoria também ressalta que os empreendimentos sociais teriam a capacidade de transformar as pessoas em agentes do processo de desenvolvimento local. Desta forma, o protagonismo das pessoas seria vetor para mudanças sociais cujas realizações podem ser julgadas de acordo com seus próprios valores e objetivos, como propõe Sen (2000). Nesse sentido, é possível considerar o empoderamento por meio da mobilização e da participação social e comunitária, por si só, como uma importante contribuição dos empreendimentos sociais para o desenvolvimento local.

A conquista de crescentes níveis de bem-estar deve ser considerada sob uma ótica que contempla a diversidade entre as pessoas e os diferentes contextos em que vivem. Ela é assegurada na medida em que a desigualdade é reduzida, não apenas em termos de melhor distribuição de riqueza, mas principalmente no acesso a oportunidades econômicas, sociais e políticas, de acordo com Sen (2000). Nos casos estudados, é possível verificar que as iniciativas ampliaram as oportunidades de atuação política dos cidadãos, como a participação social, o diálogo com o poder público e o exercício de alguns direitos de cidadania; o acesso a oportunidades sociais, como melhores condições de trabalho e de moradia; e o acesso a oportunidades econômicas, como o empreendedorismo e a melhoria nos padrões de consumo. Ou seja, os empreendimentos sociais contribuíram para reduzir a desigualdade no acesso a poder e oportunidades, removendo algumas condições que causam a privação de liberdades e fomentando a participação social.

Entretanto, a expansão das liberdades individuais não resultou em um processo no qual essas mesmas liberdades fossem usadas para tornar as disposições sociais mais apropriadas e eficazes, retroalimentando o processo, como propõe Sen (2000). No trabalho de campo da pesquisa, não se observou que as melhorias obtidas nas condições de vida das pessoas 
tivessem sido convertidas em fortalecimento da organização coletiva. É possível que essa transformação social, resultante do fortalecimento do capital social, da mobilização e organização das pessoas em torno de objetivos coletivos não seja observável senão em períodos de tempo mais longos do que aqueles que caracterizam a linha de vida dos empreendimentos estudados.

Se não há fortalecimento do capital social, sua marginalização ou sua degradação pode resultar na perda de capacidade crítica ou de consciência política destas parcelas da população, enfraquecendo o tecido social que impulsiona o desenvolvimento sustentado, como afirma Kliksberg (2007). E o risco de enfraquecimento do capital social se mostra ainda maior entre a população mais pobre, afirma aquele autor. Observou-se nos casos estudados que tal constatação constitui uma barreira à promoção do desenvolvimento almejado pelos empreendimentos sociais: pessoas empobrecidas e que enfrentam situações de crise, tais como catadores de materiais recicláveis e moradores de assentamentos precários, se veem impossibilitadas de cumprir as obrigações de reciprocidade inerentes ao fortalecimento do capital social. Assim, embora o entusiasmo inicial com propostas voltadas para a organização comunitária, autogestionária e participativa permita vislumbrar uma possibilidade de fortalecimento do capital social, tal processo tende a estagnar-se ao longo do tempo, diferentemente do que acontece entre grupos sociais que detêm mais recursos, como demonstram os estudos citados por Kliksberg (2007).

Ainda assim, os empreendimentos estudados revelaram ter capacidade para proporcionar oportunidades de acesso a trabalho remunerado e digno, geração de riqueza e renda, proteção e participação sociais com a urgência que Sachs (2001) sugere ser necessária no campo das políticas econômicas e sociais para os países menos desenvolvidos. Aquele autor reconhece que a grande dificuldade enfrentada pelos governos é a de ampliar a escala, isto é, proporcionar estas oportunidades para todos, reorientando os objetivos do crescimento econômico e eliminando as condições que originam a miséria e a exclusão. Os empreendimentos sociais atuariam, portanto, nestas lacunas deixadas pelo Estado, aliviando a pobreza e empoderando comunidades. Pode-se argumentar, contudo e com base nos casos estudados, que estes resultados têm abrangência limitada e estão descasados, em sua maior parte, de políticas públicas orientadas para a promoção do desenvolvimento social. 
Como ressalta Veiga (2012), a redução da pobreza não é automaticamente acompanhada pela redução das desigualdades sociais, pois estas permanecem enquanto o incremento nas condições de vida e no poder de compra dos mais pobres não tiver o mesmo ritmo e intensidade daquele vivenciado pelos mais ricos. Se a desigualdade persiste e a ela está alinhada a baixa capacidade dos mais pobres para participação política e transformação social, pode-se inferir que a contribuição dos empreendimentos sociais para o desenvolvimento social de forma sistêmica é pouca ou inexistente.

O estudo revelou que a finalização dos projetos desenvolvidos pelos empreendimentos sociais produz um vácuo. As pessoas por eles apoiadas dificilmente percebem que os benefícios experimentados na esfera pessoal constituem oportunidades para a promoção de mudanças sociais decorrentes da participação e da luta por direitos. A carência de consciência política, de acesso a informação e educação podem constituir fatores que levam estes grupos a não se apropriarem do conhecimento levado pelos empreendimentos sociais, o qual seria força motriz para a promoção de mudanças no plano coletivo. Talvez falte aos projetos e ações realizados por estes empreendimentos uma vertente mais objetivamente voltada para a educação política, seja como prática pedagógica, como propõe Paulo Freire em toda sua obra, ou como prática política, como fazem os movimentos sociais e as Comunidades Eclesiais de Base.

Muito já se falou sobre as consequências de o Brasil ser uma nação jovem e que, depois de tortuosos ciclos autoritários, ainda experimenta uma democracia recente. Talvez uma consequência deste processo histórico seja a inexistência de padrões culturais que enfatizem a solidariedade, a confiança e a organização social como fatores inerentes ao desenvolvimento coletivo. Mais característicos dos continentes nórdicos e de países que vivenciaram históricos político-sociais mais maduros, estes alicerces culturais alimentam as premissas que sustentam os conceitos de economia solidária, desenvolvimento local e capital social, os quais inspiram a criação de empreendimentos sociais voltados às ações de mobilização e participação social. Talvez a carência de alicerces culturais constitua um dos fatores que ressaltam, nos casos estudados, o enfraquecimento da participação social. A importância da cultura, da infraestrutura e do ambiente político em que os empreendimentos sociais operam, com ênfase na conexão que mantêm com a comunidade e sua cultura, deveria ser mais enfatizada nessas iniciativas, como também sugerem Dees (2010) e Elkinton (2010). 
Operando em realidades complexas, geralmente com recursos limitados e poucas garantias de resultados efetivos, os empreendimentos sociais estudados se caracterizam pela inovação e pela busca de melhoria nos indicadores da qualidade de vida dos grupos de pessoas que pretendem beneficiar. Se os resultados obtidos podem ser considerados limitados sob uma perspectiva ampla de desenvolvimento local, essas mesmas evidências sinalizam a existência de oportunidades para que a abrangência das mudanças ocasionadas pelos empreendimentos sociais seja crescentemente ampliada. Sinalizam, também, a importância que adquire o alinhamento entre objetivos, métodos e formas de avaliação dos projetos realizados, o qual pode garantir que transformações sociais de abrangência local e territorial sejam identificadas e mensuradas. E, a partir desses indicadores, reproduzidas e ampliadas em escalas que podem configurar efetivo impacto social.

\subsection{Limitações do estudo e recomendações para pesquisas futuras:}

A aplicação de indicadores que mensurem os resultados dos projetos e ações desenvolvidos por empreendimentos sociais mostrou-se válida mas limitada no estudo realizado, reafirmando seu caráter exploratório. Evidências e inferências permitiram a identificação, por meio do relato de diferentes informantes, de resultados que podem ser atribuídos às iniciativas realizadas pelos empreendimentos sociais. Duas abordagens poderiam ser empregadas, adicionalmente, para confirmação dos dados e mensuração mais acurada de alguns indicadores relacionados ao tipo de mudança pretendida em cada ação ou projeto. O emprego de técnicas de avaliação e monitoramento de projetos que incluam a coleta e a sistematização de dados desde o chamado "marco zero" pode oferecer indicadores que dimensionem e qualifiquem o tipo de resultado obtido para cada variável impactada pelo projeto ou ação. Já a aplicação de abordagens quantitativas poderia conferir maior precisão à magnitude deste impacto. De modo geral, os empreendimentos sociais não têm sido capazes de incluir a avaliação como parte do escopo do projeto, muito em razão da falta de recursos financeiros aportados pelos investidores com esta finalidade. Como consequência, os projetos carecem de dados sistematizados e coletados em diferentes momentos, os quais permitiriam a aplicação de técnicas mais sofisticadas de mensuração dos resultados e monitoramento de indicadores. 
Uma análise inspirada nas proposições de Stiglitz, Sen e Fitoussi (2010) pode trazer mais evidências que confirmem a contribuição dos empreendimentos sociais para a promoção do desenvolvimento social em âmbito local. Essa análise conjugaria os resultados obtidos pelos empreendimentos em termos de geração de renda e acesso a consumo com aumento da riqueza, medidos pelo PIB e PIB per capita, e sua melhor distribuição na região, mensurada pelo coeficiente de Gini. Tal análise não foi efetivada neste estudo em decorrência da inexistência de dados e indicadores macroeconômicos que acompanhem o período de realização dos projetos pesquisados, sobretudo os dois últimos anos.

Este estudo pretendeu chegar a generalizações teóricas proporcionadas por análises individuais e conjuntas de três casos. Tal tipo de generalização limita as conclusões obtidas ao conjunto de casos estudados, propiciando a identificação de determinadas características do fenômeno estudado e inferências sobre causas e consequências dos processos investigados: se os empreendimentos sociais contribuem para o desenvolvimento local, como o fazem, quais resultados obtêm e quais fatores influenciam estes resultados. Sugere-se a replicação deste estudo em outros contextos, a fim de levantar mais evidências que contribuam para a ampliação das fronteiras da generalização empírica. A replicação das categorias de indicadores utilizadas neste estudo é estimulada, sobretudo com o objetivo de aprofundar e refinar as dimensões analíticas aplicadas à perspectiva local do contexto brasileiro.

Tendo foco nos processos e resultados do fortalecimento do capital social em comunidades e territórios nos quais atuam os empreendimentos sociais, estudos futuros podem agregar importantes evidências para as discussões aqui apresentadas. Sugere-se analisar, por exemplo, como as relações de poder, traços culturais e valores influenciam a participação social e os resultados obtidos pelos empreendimentos sociais em termos de transformação e desenvolvimento local. 


\section{REFERÊNCIAS}

AGENDA 21. Conferência de Estocolmo, 1987. Disponível em: $<$ http://agenda21local.com.br/con2c.htm>. Acesso em: 01/11/2011.

ALIANÇA EMPREENDEDORA. Disponível em: http://www.aliancaempreendedora.org.br/. 2012.

ALBAGLI, Sarita; MACIEL, Maria Lúcia. Capital social e empreendedorismo local. In: LASTRES, Helena M. M.; Lemos; Cristina. Políticas para Promoção de Sistemas Produtivos Locais de MPME. Rede de Pesquisa em Sistemas Produtivos e Inovativos Locais - Universidade Federal do Rio de Janeiro, 2002. Disponível em: $<$ http://www.ie.ufrj.br/redesist/NTF2/NT\%20SaritaMLucia.PDF $>$ Acesso em: $15 / 08 / 2011$.

ALVORD, Sarah H.; BROWN, L. David; LETTS, Christine W. Social Entrepreneurship and Social Transformation: An Exploratory Study. Working Paper No. 15. Cambridge, MA: Hauser Center for Nonprofit Organizations, 2002.

APPEZZATO, Raquel. Capacitação Ocupacional e Desenvolvimento Local Sustentável: A Experiência do Projeto Pé da Serra. São Paulo, 2006. Dissertação (mestrado) - Centro de Energia Nuclear na Agricultura, Escola Superior de Agricultura "Luiz de Queiroz", Universidade de São Paulo.

ARNS, Paulo Cesaret al. Desenvolvimento Institucional e Articulação de Parcerias para o Desenvolvimento Local. Brasília: BNDES - PNUD - Série Cadernos Técnicos, 2003.

ARRIGHI, Giovanni. A Ilusão do Desenvolvimento. Petrópolis: Ed. Vozes, 1997.

ARRUDA, Marcos. Economia Solidária e o Renascimento de uma Sociedade Humana Matrística. In: IV FÓRUM SOCIAL MUNDIAL, 2004, Mumbai-Índia. Anais... Mumbai, 2004.

ARTEMÍSIA. O que são negócios sociais? Disponível em: <http://www.artemisia.org.br/entenda_o_conceito.php>. Acesso em: 09/10/2012.

ASHOKA. Empreendedorismo Social. Disponível em: $<$ http://www.ashoka.org.br/visao/empreendedorismosocial/>. Acesso em: 11/07/2011.

AUSTIN, J. E. Parcerias - Fundamentos e Benefícios para o Terceiro Setor. São Paulo: Editora Futura, 2001. 
BARDIN, Laurence. Análise de Conteúdo. Lisboa: Edições 70, 1977.

BOSCHEE, Jerr. Eight basic principles for nonprofit entrepreneurs. Madison: Non ProfitWorld, v.19, n.4, July/August 2001.

BOURDIEU, Pierre. Coisas Ditas. São Paulo: Brasiliense, 1990.

A economia das trocas simbólicas. São Paulo: Perspectiva, 2007.

BRITO, Socorro; ZAPATA, Tania. Equidade de Gênero e Desenvolvimento Local Reflexões e orientações para a prática. Brasília: Instituto de Assessoria para o Desenvolvimento Humano, 2004.

BROSE, Markus. Redes: breve introdução à arte de tecer Capital Social. Disponível em: <http://www.promenino.org.br/Ferramentas/Conteudo/tabid/77/ConteudoId/e809a3fb-acde468d-81df-8763743db56b/Default.aspx>. Acesso em 15/07/2008.

BULL, Ivan.; WILLARD, Gary E. Towards a theory of entrepreneurship. Journal of Business Venturing, Elsevier, vol. 8(3), pages 183-195, May 1993.

Câmara Municipal de São Paulo. Boletim Metropolitano da Conjuntura Social e Econômica de fevereiro 2012. $<$ http://www2.camara.sp.gov.br/CTEO/Boletim-RMSP09-fev12.pdf>. Acesso em: 04 de junho de 2012.

CASTELLS, Manuel. Investigando el emprendimiento social. In: VERNIS, Alfred; IGLESIAS, Maria. Empresas que inspiran futuro: Ocho casos de emprendedores sociales. Barcelona: ESADE, 2010.

CAVAlCANTI, Clóvis. Celso Furtado e o Mito do Desenvolvimento Econômico. Fundação Joaquim Nabuco, Trabalhos para Discussão n. 104/2001, Março 2001.

COCCO, Giuseppe; GALVÃO, Alexander Patêz. Sobre a tropicalização do Desenvolvimento Local: algumas reflexões a respeito do modelo italiano. In: SILVEIRA, Caio Márcio; REIS, Liliane da Costa. (Orgs.). Desenvolvimento Local: dinâmicas e estratégias. Rio de Janeiro: RITS - Rede de Informações para o Terceiro Setor, 2001.

COMINI, Graziella Maria. Negócios Sociais e Inclusivos: um panorama da diversidade conceitual. In: Ashoka e Instituto Walmart. Mapa de soluções inovadoras: Tendências de empreendedores na construção de negócios sociais e inclusivos. São Paulo, 2011.

COMMUNITY WEALTH VENTURES. Powering Social Change: Lessons on Community Wealth Generation for Nonprofit Sustainability. Washington DC: CommunityWealth Ventures, 2003. 
CRESPO, Ricardo. Martha Nussbaum y las diez capacidades básicas del desarrollo. SD. Disponível em: <http://www.materiabiz.com/mbz/gurues.vsp?nid=34888>. Acesso em: 06/07/2011.

DALY, Herman E. Desenvolvimento Sustentável: Definições, Princípios, Políticas. Cadernos de Estudos Sociais, Recife: Fundação Joaquim Nabuco.v. 18, n. 2, jul./dez., pp. 171-184, 2002.

DEES, J. Gregory. The Meaning of “Social Entrepreneurship”. 2001. Disponível em: $<$ http://www.caseatduke.org/documents/dees_sedef.pdf $>$. Acesso em: 16/11/2011.

Creating large-scale change: Not 'can' but 'how'. McKinsey Digital, 2010. Disponível em: <http://www.mckinseyquarterly.com/spContent/2010_04_07.html>. Acesso em: 19/08/2011.

DRAYTON, Bill. Tipping the world: The power of collaborative entrepreneurship. McKinsey\&Company, 2010. Disponível em: $<$ http://www.mckinseyquarterly.com/spContent/2010_04_07.html>. Acesso em: 30/05/2011.

DRUCKER, Peter F. Innovation and entrepreneurship: practice and principles. London: Heinemann, 1985.

EHLERS, Eduardo Mazzaferro. Determinantes da recuperação da Mata Atlântica no Estado de São Paulo. São Paulo, 2003. Tese (Doutorado em Ciência Ambiental). PROCAM - Universidade de São Paulo.

EISENHARDT, Kathleen M. Building Theories from Case Study Research. The Academy of Management Review, Vol. 14, No. 4. (Oct., 1989), pp. 532-550.

ELKINGTON, John. A new paradigm for change. McKinsey Digital, 2010. Disponível em: < http://www.mckinseyquarterly.com/spContent/2010_04_07.html>. Acesso em 19/08/2011.

FARFUS, Daniele. Empreendedorismo social e desenvolvimento local: um estudo de caso no SESI Paraná. Curitiba,2008. Dissertação (mestrado). Centro Universitário Franciscano do Paraná - UNIFAE.

FILLION, Louis Jacques. O Empreendedorismo como Tema de Estudos Superiores. Palestra proferida no Seminário "A Universidade Formando Empreendedores". Montreal:Escola de Altos Estudos Comerciais (H.E.C) s.d., Disponível em: $<$ http://inf.unisul.br/ ingo/emoreendedorismo.pdf >. Acesso em: 08/08/2008.

FISCHER, Rosa Maria. O Desafio da Colaboração. São Paulo: Gente, 2002. 
Empreendedorismo social: apontamentos para um debate. In: Centro Ruth Cardoso (org.). Políticas sociais: ideias e prática. São Paulo: Ed. Moderna, 2011.

FISCHER, Rosa Maria; et al. Desafios da atuação social através de alianças intersetoriais. In: FEA/USP. Anais do IV SEMEAD - Seminários em Administração. São Paulo: FEA/USP, 22/25 março, 2003.

RIGHETTI, Sabine. ONU Cria outra forma de medir riqueza. Folha de São Paulo. São Paulo, p. C4, 18/06/2012.

FRANÇA FILHO, Genauto \& LAVILLE, Jean Louis. Economia solidária: uma abordagem internacional. Porto Alegre: Editora da UFRGS, 2004.

FRANCO, Augusto de. Porque precisamos de Desenvolvimento Local Integrado e sustentável. Brasília: Agência de Educação para o desenvolvimento, 2000.

Fundação Seade - Fundação Sistema Estadual de Análise de Dados. Informações dos Municípios Paulista - IMP. São Paulo, 2012a. Disponível em: <http://www.seade.gov.br/produtos/imp/> Acesso em: 23 de maio de 2012.

Informações dos Municípios Paulista - IMP. São Paulo, 2012b. Disponível em: $<$ http://www.seade.gov.br/produtos/imp/>. Acesso em: 23 de maio de 2012.

FUNDAÇÃO TIDE SETÚBAL; GIFE. Desenvolvimento local e fundações comunitárias em áreas urbanas. São Paulo, Fundação Tide Setúbal; Gife, 2010.

FUNDO ZONA LESTE SUSTENTÁVEL. Relatório de Atividades 2010-2011.

FURTADO, Celso. 1974. O Mito do Desenvolvimento Econômico. Rio de Janeiro: Paz e Terra.

GIL, Antonio Carlos. Métodos e Técnicas de Pesquisa Social. São Paulo, Atlas, 1994.

GODÓI-DE-SOUSA, Edileusa. O processo sucessório em associações produtivas no Brasil: estrutura, desafios e oportunidades. São Paulo, 2010. Tese (Doutorado em Administração). FEA - Universidade de São Paulo.

GOMES, Almiralva Ferraz. O empreendedorismo como uma alavanca para o desenvolvimento local. Revista Eletrônica de Administração - REA. Ano 2005 - Edição 07 - Volume 06 - Número 02 - Julho/Dezembro 2005.

GONÇALVES, Daniel Bertoli. Desenvolvimento sustentável: o desafio da presente geração. Revista Espaço Acadêmico N.51, Agosto de 2005. 
GRISI, Fernando Correa. Empreendedorismo social: uma pesquisa exploratória de ações de disseminação no Brasil. São Paulo, 2008. Dissertação (mestrado). Pontifícia Universidade Católica, 2008.

HADDAD Paulo R. Texto de Referência da Palestra Sobre Cultura Local e Associativismo. Belo Horizonte, setembro de 2004. Disponível em: <www.bndes.gov.br/conhecimento/seminario/apl> . Acesso em: 10/05/2008.

IBGE - Instituto Brasileiro de Geografia e Estatística. Cidades@. Disponível em: $<$ http://www.ibge.gov.br/cidadesat/default.php>. Acesso em: 16 de maio de 2012.

Estimativa Populacional 2011. Rio de Janeiro, 2011a. Disponível em: $<$ http://www.ibge.gov.br/home/estatistica/populacao/estimativa2011/estimativa.shtm>. Acesso em: 14 de maio de 2012.

Disponível

Produto Interno Bruto dos Municípios 2005-2009. Rio de Janeiro, 2011b. <http://www.ibge.com.br/home/estatistica/economia/pibmunicipios/2005_2009/default.shtm> . Acesso em: 14 de maio de 2012.

Disponível

Censo Demográfico 2010. Resultados gerais da amostra. Rio de Janeiro, 2011c. <http://www.ibge.com.br/home/estatistica/populacao/censo2010/resultados_gerais_amostra/d efault_resultados_gerais_amostra.shtm>. Acesso em: 05 de junho de 2012.

. Censo Demográfico 2010. Características da população e dos domicílios: Resultados do universo. Rio de Janeiro, 2011d. Disponível em: $<\underline{\text { http://www.ibge.com.br/home/estatistica/populacao/censo2010/caracteristicas_da_populaca }}$ o/default_caracteristicas_da_populacao.shtm>. Acesso em: 28 de maio de 2012.

. Censo Demográfico 2010. Aglomerados subnormais: Primeiros resultados. Rio de Janeiro, 2011e. Disponível em: <http://www.ibge.com.br/home/estatistica/populacao/censo2010/aglomerados_subnormais/de fault_aglomerados_subnormais.shtm>. Acesso em: 30 de maio de 2012.

Pesquisa de Assistência Médico-Sanitária. Rio de Janeiro, 2009. Disponível em: <http://www.ibge.com.br/home/estatistica/populacao/condicaodevida/ams/2009/default.shtm> . Acesso em: 04 de junho de 2012.

INTERAÇÃO. http://www.redeinteracao.org.br/. 2012

JACKSON, Tim. Prosperity without Growth? The transition to a sustainable economy. Sustainable Development Commission, 2009. 
JACOBI, Pedro Roberto; BESEN, Gina Rizpah. Gestão de resíduos sólidos em São Paulo: desafios da sustentabilidade. Estudos Avançados [online].2011, v.25, n.71, pp.135-158.

JOHNSON, Sherrill. Literature review on Social Entrepreneurship. Canadian Centre for Social Entrepreneurship, November 2000.

KING, Charles. The Need for a New Paradigm: Social Entrepreneurship. In: Community Wealth Ventures. Powering Social Change: Lessons on Community Wealth Generation for Nonprofit Sustainability. CommunityWealth Ventures, Inc. Washington DC, 2003. 122p.

KLIKSBERG, Bernardo. O desafio da exclusão: por uma gestão social eficiente. São Paulo: Fundap, 1997

Falácias e mitos do desenvolvimento social. São Paulo: Cortez; Brasília, DF: UNESCO, 2003, 2 ed.

Os desafios éticos de um continente paradoxal. In: SEN, Amartya; KLIKSBERG, Bernardo. As pessoas em primeiro lugar: A ética do desenvolvimento e os problemas do mundo globalizado. São Paulo: Companhia das Letras, 2007.

LANGLEY, Ann. Strategies for theorizing from process data.Academy of Management.The Academy of Management Review; Oct 1999; 24, 4; ABI/ INFORM Global pg.691.

LEITE, Marcia de Paula. A economia solidária e o trabalho associativo: teorias e realidades. Revista Brasileira de Ciências Sociais, São Paulo,v. 24,n. 69, Feb. 2009. Disponível em $<$ http://www.scielo.br/scielo.php?script=sci_arttext\&pid=S010269092009000100003\&lng=en\&nrm=iso>. Acesso em: 16/11/2011.

LIGHT, Paul C. Collaboration: An opportunity for lasting change. McKinsey Digital, 2010. Disponível em: <http://whatmatters.mckinseydigital.com/social_entrepreneurs/collaborationan-opportunity-for-lasting-change >. Acesso em: 19/08/2011.

LIMA, José Luiz de Souza. Empreendedorismo Social: uma perspectiva de cidadania social e uma alternativa de trabalho e renda nos espaços populares. Rio de Janeiro, 2008. Dissertação (Mestrado). Pontifícia Universidade Católica do Rio de Janeiro.

LISBOA, Armando de Melo. Os desafios da Economia Popular e Solidária. Disponível em: $<$ http://www.humanas.unisinos.br/pesquisa/ecosol/txt/desafios.doc $>$. Acesso em:15/10/09.

LOURENÇO, Maria Salvelina Marques. Trabalho Pleno: Construção do Desenvolvimento Local. Sobral: Edições UVA, 2003.

MARTIN, Roger L.; OSBERG, Sally. Social Entrepreneurship: The Case for Definition. Standford Social Innovation Review, Spring 2007. Disponível em: 


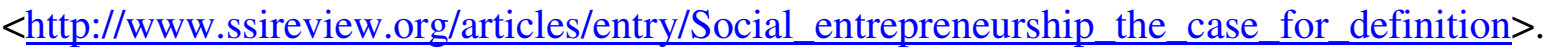
Acesso em: 16/11/2011.

MAKHLOUF, Hany H. Social Entrepreneurship: Generating Solutions to Global Challenges. International Journal of Management and Information Systems. Littleton: First Quarter 2011. Vol. 15, No . 1; pag. 1 (8 páginas).

MARCOVITCH, Jacques. A governança internacional do meio ambiente. In: Ribeiro, Wagner Costa (org). Governança da Ordem Ambiental Internacional e Inclusão Social. São Paulo, Annablume; Procam; IEE, 2012.

MARQUES, Patricia; REFFICO, Ezequiel; BERGER, Gabriel (editors). Socially Inclusive Business: Engaging the Poor through Market Initiatives in Iberoamerica. Cambridge, Massachusetts: David Rockefeller Center Series on Latin American Studies, Harvard University Press, 2010

MARTIN, Maximilian. Seizing the Promise of Social Entrepreneurship. (July 1, 2006). Perspectivas, pp. 48-55, 2006. Disponível em: <http://ssrn.com/abstract=1322447>. Acesso em: 15 junho de 2009.

MARTÍN CRIADO, Enrique. El concepto de campo como herramienta metodológica. Revista Española de Investigaciones Sociológicas, $\mathrm{n}^{\mathrm{0}}$ 123, 2008, pp. 11-33. Disponível em: $<$ http://www.reis.cis.es/REIS/PDF/REIS_123_011215166984248.pdf>. Acesso em: $20 / 09 / 2011$.

MAYORAL BLASCO, Susana. El mobbing y la teoría de la acción de Pierre Bourdieu. Revista Internacional de Sociología (RIS), Vol.68, $\mathrm{n}^{\mathrm{o}}$ 2, Mayo-Agosto, 375-398, 2010. Disponível em: $<$ http://revintsociologia.revistas.csic.es/index.php/revintsociologia/article/download/332/338> . Acesso em: 20/09/2011.

MICELI, Sergio. A força do sentido. In: Bourdieu, P. A economia das trocas simbólicas. São Paulo: Perspectiva, 2007.

MILANI, Carlos. Teorias do Capital Social e Desenvolvimento Local: lições a partir da experiência de Pintadas (Bahia, Brasil). IV Conferencia Regional ISTR-LAC. 8-10 de octubre, 2003, San José, Costa Rica. Anais... San Jose: ISTR, 2003.

MISOCZKY, Maria Ceci A. "Implicações do uso das formulações sobre campo de poder e ação de Bourdieu nos estudos organizacionais". Revista de Administração Contemporânea, vol. 7, núm. spe, 2003, pp. 9-30.

MONZONI NETO, Mario. P. Impacto em renda do Microcrédito. São Paulo: Peirópolis, 2008 . 
MOREIRA, Vilma et al. Empreendedorismo Social e Economia Solidária: Um Estudo de Caso da Rede de Desenvolvimento Local Integrado e Sustentável da Comunidade do Grande Bom Jardim. In: XXXVIII ASSEMBLEIA DO CONSELHO LATINOAMERICANO DE ESCOLAS DE ADMINISTRAÇÃO. Lima, Peru, 2003. Anais... Lima, CLADEA, 2003.

MOURA, Anita Maria. Facilitadores e dificultadores na implementação de um negócio inclusivo em três países de diferentes continentes. São Paulo, 2011. Dissertação (mestrado). Faculdade de Economia, Administração e Contabilidade - Universidade de São Paulo..

MOZZATO, Anelise Rebelato; Grzybovski, Denize. Documentos e Debates: Análise de Conteúdo. RAC, Curitiba, v. 15, n. 4, pp. 731-747, Jul./Ago. 2011. Disponível em: $<$ www.anpad.org.br/rac $>$. Acesso em: 21/09/2012.

NAGLER, Jürgen. Is social entrepreneurship important for economic development policies? Sydney: University of new South Wales, 2007.

NELSON, J. e ZADEK, S. Partnership Alchemy: new social partnerships in Europe. Copenhagen: The Copenhagen Centre, 2001.

NICHOLLS, Alex. Playing the Field: a New Approach to the Meaning of Social Entrepreneurship. Social Enterprise Journal. 2.1, pp. 1-5, 2006.

NOVAES, Marcos Bidart Carneiro de.;GIL, Antonio Carlos. A pesquisa-ação participante como estratégia metodológica para o estudo do empreendedorismo social em administração de empresas. Revista de Administração Mackenzie, Vol. 10, No 1 (2009).

ODARA, Mafoane. Empreendedorismo Social - construindo o conceito, transformando o setor social. São Paulo, Ashoka Empreendedores Sociais, 2011. Disponível em: $<$ http://www.educandusweb.com.br/ewce/portal/formularios/apoio/arquivos/apoio998_4.\%20 o\%20que\%20\%E9\%20empreendedorismo\%20social.pdf > . Acesso em: 26/10/2011.

OLIVEIRA, Edson Marques. Empreendedorismo social no Brasil: fundamentos e estratégias. Franca, 2003. Tese (Doutorado). Faculdade de História, Direito e Serviço Social Universidade Estadual Paulista "Julio de Mesquita Filho".

O empreendedorismo social indutor de auto-organização no enfrentamento das questões sociais e no desenvolvimento integrado e sustentável: notas introdutórias e aproximativas. Informe GEPEC, vol. 8, no. 1. Universidade Estadual do Oeste do Paraná. Paraná, 2004a.

Empreendedorismo social no Brasil: atual configuração, perspectivas e desafios notas introdutórias. Revista da FAE, vol. 7, no. 2, p.9-18. Curitiba, 2004b 
OLIVEIRA, Francisco de. Aproximações ao Enigma: que quer dizer desenvolvimento local? São Paulo: Instituto Polis, 2001.

OSBERG, Sally. Driving change: It's not just about size. McKinsey Digital, 2010. Disponível em: <http://whatmatters.mckinseydigital.com/social_entrepreneurs/drivingchange-it-s-not-just-about-size>. Acesso em: 19/08/2011.

PETTIGREW, A. M. The Awakening Giant: Continuity and Change in ICI. Oxford: Blackwell; 1985.

PNUD - Programa das Nações Unidas para o Desenvolvimento. Relatório de Desenvolvimento Humano 2010. A Verdadeira Riqueza das Nações: Vias para o Desenvolvimento Humano. New York: PNUD, 2010.

Relatório de Desenvolvimento Humano 2011. Sustentabilidade e equidade: Um futuro melhor para todos. New York, PNUD, 2011.

PNUD no Brasil. IDH. Brasília, 2011. Disponível em: <http://www.pnud.org.br/IDH.aspx\#>. Acesso em: 12 de junho de 2012.

Ranking decrescente do IDH-M dos municípios do Brasil. Brasília, 2000. Disponível em: $\quad<$ http://www.pnud.org.br/atlas/ranking/IDHM\%2091\%2000\%20Ranking\%20decrescente\%20(pelos\%20dados\%20de\%202000).htm>.

Acesso em: 27 de maio de 2008.

PUTNAM, Robert. Comunidade e Democracia:a experiência da Itália Moderna. Rio de Janeiro: Ed. Fundação Getúlio Vargas, 1996.

QUADIR, Iqbal Z. The economics of social progress. McKinsey Digital, 2010. Disponível em: <http://whatmatters.mckinseydigital.com/social_entrepreneurs/the-economics-of-socialprogress >. Acesso em: 19/08/2011.

ROBERTT, Pedro. La organización empresarial como un campo de luchas: cuestiones metodológicas y pormenores de investigación. EMPIRIA Revista de Metodología de Ciencias Sociales. N.o 20, julio-diciembre, 2010, pp. 165-185..

ROCHE, Chris. Avaliação de impactos dos trabalhos de ONGs: aprendendo a valorizar as mudanças. São Paulo: Cortez, 2002.

ROSAS, André Rosenfeld. Modelo conceitual de jogos de empresas para empreendedores do século XXI. São Paulo, 2006. Dissertação (Mestrado). FEA - Universidade de São Paulo. 
ROVETTA DA SILVA, Adrian. O Papel das Políticas Públicas no Desenvolvimento Sustentável do Arranjo Produtivo Moveleiro de Ubá-MG. Viçosa, 2008. Dissertação (Mestrado). Universidade Federal de Viçosa.

SACHS, Ignacy, Estratégias de transição para o século XXI: Desenvolvimento e meio ambiente. São Paulo: Studio Nobel, Fundap, 1993.

Repensando o crescimento econômico e o progresso social: o papel da política. In: ABRAMOVAY, Ricardo et al. (Orgs.). Razões e ficções do desenvolvimento. São Paulo: Editora Unesp/Edusp, 2001.

2004

Desenvolvimento includente, sustentável, sustentado. Rio de Janeiro: Garamond,

A Terceira Margem - em busca do ecodesenvolvimento. São Paulo: Companhia das Letras, 2009.

SACHS, Ignacy.; LAGES, Vinicius Nobre. Capital social e desenvolvimento: novidade para quem? - Conferencia Regional sobre Capital Social y Pobreza - Organizadores: CEPAL y Universidad del Estado de Michigan - Santiago, Chile 24 a 26 de septiembre de 2001.

SCHÄFER, Heinrich Wilhelm. Habitus-Analysis: a method to analyze cognitive operators of practical logic. Contribution to the Congress beyond Bourdieu - Habitus, Capital \& Social Stratification. University of Copenhagen - December 1st.-2nd. 2009.

SCHUMPETER, Joseph Alois. Capitalismo, Socialismo e Democracia. Rio de Janeiro: Zahar Editores, 1976.

On the concept of social value. Quarterly Journal of Economics, volume 23, 19089.Pp. 213-232.

SAE - Secretaria de Assuntos Estratégicos. Vozes da Classe Média. Disponível em: $<$ http://www.sae.gov.br/vozesdaclassemedia/>. Acesso em: 21/09/2012.

SEKN.Effective Management of Social Enterprises: Lessons from Businesses and Civil Society Organizations in Iberoamerica. Cambridge, Massachusetts: David Rockefeller Center for Latin American Studies, Harvard University Press, 2006.

SEKN. Negocios Inclusivos: iniciativas de Mercado com los pobres de Iberoamérica. Washington, D.C: BancoInteramericano de Desarrollo, David Rockefeller Center for Latin American Studies, Harvard University, 2010.

SEN, Amartya. Desenvolvimento como liberdade. São Paulo: Companhia das Letras, 2000. 
Por que é necessário preservar a coruja-pintada. Folha de São Paulo, 14 mar.2004, Caderno Mais, p.16.

Temas-chave do Século XXI. In: SEN, Amartya; KLIKSBERG, Bernardo. As pessoas em primeiro lugar: A ética do desenvolvimento e os problemas do mundo globalizado. São Paulo, Companhia das Letras, 2007.

Desigualdade reexaminada. Rio de Janeiro: Record, 2008.

SELLTIZ, Claire et al. Métodos de Pesquisa nas Relações Sociais. São Paulo, EPU, 1975.

SILVA, Sheila Maria Palza Silva. Estado e políticas públicas no mercado de castanha-dobrasil no Estado do Acre: uma análise pela abordagem do desenvolvimento local. Revista IDeAS - Interfaces em Desenvolvimento, Agricultura e Sociedade, Rio de Janeiro - RJ, v. 4, n. 1 , p. 103-128, jun./jul. 2010. Disponível em $<$ http://www.ufrrj.br/cpda/ideas/revistas/v04/n01/IDeAS-v04_n01-

Artigo_SHEILA_MARIA_PALZA_DA_SILVA.pdf>. Acesso em: 15/08/2011.

SOUZA NETO, Silvestre Prado de.; SALES, Alessandro Heleno Lima. Empreendedorismo: um modelo de liderança para o século XXI. Publicações FAE - I Seminário de Gestão de Negócios, s.d.

SINGER, Paul. É possível levar o desenvolvimento a comunidades pobres? Texto para discussão. Brasília: Secretaria Nacional de Economia Solidária - Ministério do Trabalho e Emprego, 2004.2 Disponível em

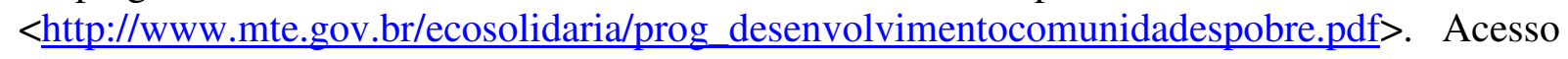
em: 16/11/2011.

STIGLITZ, Joseph E.; SEM, Amartya; FITOUSSI, Jean-Paul.Report by the Commission on the Measurement of Economic Performance and Social Progress, 2010. Disponível em

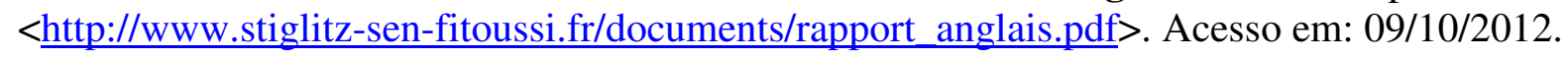

STRICKLANDJR., William E. Entrepreneurship and the Nonprofit World in: COMMUNITY WEALTH VENTURES. Powering Social Change: Community Wealth Ventures, Inc. Washington DC, 2003. 122p.

UNIVERSIA-KNOWLEDGE@WHARTON. Empreendedores sociais assumem o papel de agentes de mudança na sociedade. Wharton, University of Pennsylvania, 2005. Disponível em:

$<$ http://www.wharton.universia.net/index.cfm?fa=viewArticle\&id=597\&language=portugues e>. Acesso em: 06 de Julho de 2011.

VAN PARIJS, Philippe. A Basic Income for All. If you really care about freedom, give people an unconditional income. Boston Review, 2000. 
VECCHIATTI, Karin. Três fases rumo ao desenvolvimento sustentável: do reducionismo à valorização da cultura. São Paulo em Perspectiva, 18(3): 90-95, 2004.

VEIGA, José Eli da. Desenvolvimento Sustentável: o Desafio do Século XXI. Rio de Janeiro: Garamond, 2005a.

Empreendedorismo e desenvolvimento no Brasil rural. Revista da Universidade Estadual de Montes Claros — Unimontes. Montes Claros, v.7, n.2 - jul./dez. 2005b.

O nexo sócio-ecônomico da agenda global. in: Ribeiro, Wagner Costa (org). Governança da Ordem Ambiental Internacional e Inclusão Social. São Paulo, Annablume; Procam; IEE, 2012.

VERNIS, Alfred; IGLESIAS Maria. Empresas que inspiran futuro: Ocho casos de emprendedores sociales. Barcelona, ESADE, 2010.

VILARINHO, Paulo Ferreira. "O campo da saúde suplementar no Brasil à luz da teoria do poder simbólico de Pierre Bourdieu". Cadernos EBAPE.BR, Volume II, Número 3, Dezembro 2004.

WESTERMANN, Olaf. Poverty, Access and Payment for Watershed Hydrological Services. A social feasibility study with case in Tiquipaya Watershed Bolivia. RoskildeUniversity Centre, Denmark, 2007, pp. 72-85

YIN, Robert K. Estudo de Caso: Planejamento e Métodos. 4 ed. Porto Alegre, Bookman, 2010.

ZAMBAM, Neuro José. A Teoria da Justiça de Amartya Sen: Liberdade e Desenvolvimento Sustentável. Porto Alegre, 2009. Tese (Doutorado). Pontifícia Universidade Católica. 


\section{APÊNDICES}

APÊNDICE 1: ROTEIROS DE ENTREVISTAS 


\section{APÊNDICE 1: ROTEIROS DE ENTREVISTAS}

\section{Legenda:}

EMPREENDIMENTO SOCIAL: Fundo Zona Leste Sustentável, Aliança Empreendedora ou Interação.

INICIATIVA: Projeto realizado localmente - fomento aos empreendedores locais (Fundo Zona Leste), mobilização e urbanização da Comunidade dos Portais (interação) e cooperativismo (Cooperativa Vira-Lata)

\section{Informante 1: FUNDADOR}

1.1. O que motivou você a criar a "INICIATIVA"?

1.2. Quais experiências anteriores influenciaram a criação da "INICIATIVA"?

1.3. Por que você acreditou que a "INICIATIVA" daria certo?

1.4. Quais foram as premissas ou as condições básicas para desenvolvimento e implantação da "INICIATIVA"?

1.5. Quais foram os ativos e os recursos básicos mobilizados para desenvolvimento e implantação da "INICIATIVA"?

1.6. Qual o volume de recursos alocado inicialmente e atualmente na "INICIATIVA": (Recursos financeiros, Recursos humanos, Infra-estrutura e recursos materiais)

2.1. Quais pessoas, instituições ou organizações foram importantes na concepção, no desenvolvimento e na implantação da "INICIATIVA"? Histórico?

2.2. Houve pessoas, instituições ou organizações que atrapalharam na concepção, no desenvolvimento e na implantação da "INICIATIVA"? Histórico?

2.3. Quais pessoas, instituições ou organizações são importantes atualmente para que a "INICIATIVA" atinja seus objetivos? Histórico?

3.1. Quais eram os resultados pretendidos pela "INICIATIVA" para a comunidade abrangida?

3.2. Para cada resultado pretendido, identificar: Quais mudanças foram percebidas a partir da "INICIATIVA"?

3.3. Nos casos em que ainda não foi constatada mudança, quais causas você identifica?

3.4. Você observa que foram obtidos outros resultados além daqueles inicialmente planejados? Quais? 
3.5. Como você avalia a participação e compromisso das pessoas que a "INICIATIVA" pretendeu beneficiar ao longo do tempo e atualmente?

3.6. Como será a continuidade da "INICIATIVA" com a redução da participação do "EMPREENDIMENTO SOCIAL" ao longo do tempo?

\section{Informante 2: COORDENADOR OU TÉCNICO}

1.1. Como você chegou à "INICIATIVA"?

1.2. O que motiva você a participar da "INICIATIVA"?

1.3. Por que você acreditou e acredita que a "INICIATIVA" daria certo?

1.4. Quais são as premissas ou as condições básicas para a realização da "INICIATIVA"?

1.5. Quais ativos e os recursos básicos são mobilizados na realização da "INICIATIVA"?

1.6. Qual o volume de recursos alocado inicialmente e atualmente na "INICIATIVA": (Recursos financeiros, Recursos humanos, Infra-estrutura e recursos materiais)

2.1. Quais pessoas, instituições ou organizações foram importantes na concepção, no desenvolvimento e na implantação da "INICIATIVA"? Histórico?

2.2. Houve pessoas, instituições ou organizações que atrapalharam na concepção, no desenvolvimento e na implantação da "INICIATIVA"? Histórico?

2.3. Quais pessoas, instituições ou organizações são importantes atualmente para que a "INICIATIVA" atinja seus objetivos? Histórico?

3.1. Que mudanças a "INICIATIVA" quer trazer para a comunidade abrangida?

3.2. Para cada resultado pretendido, identificar: Quais mudanças foram percebidas a partir da "INICIATIVA"?

3.3. Nos casos em que ainda não foi constatada mudança, quais causas você identifica?

3.4. Que outras mudanças são visíveis para as pessoas que participam da "INICIATIVA" ou para a comunidade no qual a "INICIATIVA" é desenvolvida?

3.5. Como você avalia a participação e compromisso das pessoas que a "INICIATIVA" pretendeu beneficiar ao longo do tempo e atualmente?

3.6. Quais demandas ou necessidades a "INICIATIVA" apresenta para seu fortalecimento ou continuidade?

3.7. Como será a continuidade da "INICIATIVA" com a redução da participação do "EMPREENDIMENTO SOCIAL" ao longo do tempo?

\section{Informante 3: Empreendedor local ou liderança local}

1.1. O que motivou você a criar/participar da "INICIATIVA"? 
1.2. Quais experiências anteriores motivaram você a criar/participar da "INICIATIVA"?

1. 3 Por que você acreditou e acredita que a "INICIATIVA" daria certo?

1.4. Quais foram as condições básicas para que a "INICIATIVA" se concretizasse ou para que você participasse da "INICIATIVA"?

1.5. Quais foram os ativos e os recursos básicos mobilizados para desenvolvimento e implantação da "INICIATIVA"?

1.6. Qual o volume de recursos investido inicialmente e atualmente na "INICIATIVA" (Recursos financeiros, Recursos humanos, Infra-estrutura e recursos materiais)

1.7. Você teve que fazer algum tipo de investimento adicional em decorrência da "INICIATIVA"? Qual?

1.8. Como foi construída a parceria com o EMPREENDIMENTO SOCIAL?

1.9. Quais contribuições o EMPREENDIMENTO SOCIAL trouxe para as atividades realizadas pela "INICIATIVA"?

1.10. Quais contribuições o EMPREENDIMENTO SOCIAL trouxe para os resultados da "INICIATIVA"?

2.1. Quais pessoas, instituições ou organizações foram importantes na concepção, no desenvolvimento e na implantação da "INICIATIVA"? Histórico?

2.2. Houve pessoas, instituições ou organizações que atrapalharam na concepção, no desenvolvimento e na implantação da "INICIATIVA"? Histórico?

2.3. Quais pessoas, instituições ou organizações são importantes atualmente para que a "INICIATIVA" atinja seus objetivos? Histórico?

3.1. Com quais objetivos a "INICIATIVA" foi criada?

3.2. Em algum momento a "INICIATIVA" pretendeu trazer algum tipo de mudança ou melhoria para a comunidade no qual se insere? Quais?

3.3. Para cada resultado pretendido, identificar: Quais mudanças foram percebidas a partir da "INICIATIVA"?

3.4. Nos casos em que ainda não foi constatada mudança, quais causas você identifica?

3.5. Desde que você faz parte da "INICIATIVA", quais mudanças são visíveis para as pessoas que participam da "INICIATIVA" ou para a comunidade no qual a "INICIATIVA" é desenvolvida?

3.6. Como você avalia a participação e compromisso das pessoas com a "INICIATIVA" ao longo do tempo e atualmente? 
3.7. Quais demandas ou necessidades a "INICIATIVA" apresenta para seu fortalecimento ou continuidade?

3.8. Como será a continuidade da "INICIATIVA" com a redução da participação do "EMPREENDIMENTO SOCIAL" ao longo do tempo?

\section{Informante 4: Participantes ou beneficiários}

1.1. O que levou você a criar/participar da "INICIATIVA"?

1.2. Quais experiências anteriores motivaram você a criar/participar da "INICIATIVA"?

1. 3 Por que você acreditou e acredita que a "INICIATIVA" daria certo?

1.4 Quais foram as condições acordadas para que você participasse da "INICIATIVA"?

1.5. Quais contribuições você acha que o "EMPREENDIMENTO SOCIAL" trouxe para as atividades realizadas pela "INICIATIVA"?

1.6. Quais contribuições você acha que o "EMPREENDIMENTO SOCIAL" trouxe para os resultados da "INICIATIVA"?

3.5. Desde que você faz parte da "INICIATIVA", quais mudanças são visíveis na sua vida para a comunidade no qual a "INICIATIVA" é desenvolvida?

3.2. Como você avalia a participação e compromisso das pessoas com a "INICIATIVA" ao longo do tempo e atualmente? 